\title{
Fatigue Performance of Uncoated and Galvanized Composite Press-Brake-Formed Tub Girders
}

\author{
Robert M. Tennant
}

Follow this and additional works at: https://researchrepository.wvu.edu/etd

\section{Recommended Citation}

Tennant, Robert M., "Fatigue Performance of Uncoated and Galvanized Composite Press-Brake-Formed Tub Girders" (2018). Graduate Theses, Dissertations, and Problem Reports. 6783.

https://researchrepository.wvu.edu/etd/6783

This Thesis is protected by copyright and/or related rights. It has been brought to you by the The Research Repository @ WVU with permission from the rights-holder(s). You are free to use this Thesis in any way that is permitted by the copyright and related rights legislation that applies to your use. For other uses you must obtain permission from the rights-holder(s) directly, unless additional rights are indicated by a Creative Commons license in the record and/ or on the work itself. This Thesis has been accepted for inclusion in WVU Graduate Theses, Dissertations, and Problem Reports collection by an authorized administrator of The Research Repository @ WVU. For more information, please contact researchrepository@mail.wvu.edu. 


\title{
FATIGUE PERFormANCE OF UNCOATED AND GALVANIZED COMPOSITE PRESS-BRAKE-FORMEd TUB GIRDERS
}

\author{
Robert M. Tennant \\ Thesis submitted to the \\ Benjamin M. Statler College of Engineering and Mineral Resources \\ at \\ West Virginia University \\ on partial fulfillment of the requirements \\ for the degree of \\ Master of Science \\ in \\ Civil and Environmental Engineering
}

Karl E. Barth, Ph.D., Chair

Gregory K. Michaelson, Ph.D.

John P. Zaniewski, Ph.D.

Department of Civil and Environmental Engineering

Morgantown, West Virginia

2018

Keywords: steel bridge, press-brake-formed tub girders, experimental testing, fatigue 


\author{
ABSTRACT \\ Fatigue Performance of UnCoATEd AND GalVANized \\ COMPOSITE PRESS-BRAKE-FORMED TUB GIRDERS
}

\title{
Robert M. Tennant
}

The Short Span Steel Bridge Alliance (SSSBA) is a group of bridge and culvert industry leaders (including steel manufacturers, fabricators, service centers, coaters, researchers, and representatives of related associations and government organizations) who have joined together to provide educational information on the design and construction of short span steel bridges in installations up to 140 feet in length. Within the SSSBA technical working group, a modular, shallow press-brake-formed steel tub girder was developed. This new technology consists of coldbending standard mill plate width and thicknesses to form a trapezoidal box girder. The steel plate can be uncoated or galvanized steel, as each is an economical option. Once the plate has been press-brake-formed, shear studs are welded to the top flanges. A reinforced concrete deck is cast on the girder in the fabrication shop and allowed to cure, forming a composite modular unit. The composite tub girder is shipped to the bridge site, expediting construction and reducing traffic interruptions.

The increased use of the press-brake-formed tub girders has led to the recognition that longterm service life testing of different steel types in this system have not been investigated. The coldbending of the steel plate into the desired tub-girder shape creates residual stresses in the bends of the girder. At this time, the majority of prefabricated bridge elements undergoing fatigue testing are of traditional structural shapes. It is currently unknown if the high heat of galvanization affects the residual stresses in the bends of the tub girder.

The scope of this project is to determine if hot-dip galvanization affects the fatigue performance of a cold-bent shallow press-brake-formed steel tub girder. Two composite steel tub girders were constructed, one composed of an uncoated steel tub and the second composed of a galvanized steel tub. The composite system was fatigue loaded simulating a 75-year life in a rural environment. At a predetermined number of load cycles, a Service II load was applied to the system to observe the performance of the specimen. Strain gages were applied to the webs and bottom flange of each section to determine the actual moments induced in the system. Experimental results were used to evaluate any difference in the performance of the different steels used in the composite tub girder system. Results from this project show the type of steel does not have an influence on the fatigue performance of press-brake-formed tub girders. 


\section{ACKNOWLEDGEMENTS}

First, I would like to thank my advisor Dr. Karl Barth for his guidance and direction through my pursuit of a Master of Science. His encouragement and support throughout my graduate school was invaluable and I could not think of a better advisor and mentor at WVU.

I would also like to thank Dr. Gregory Michaelson and Dr. John Zaniewski for serving as members of my advisory committee. Dr. Michaelson's support and guidance in the computer analysis of the design example and calculation section properties cannot be understated. Dr. Zaniewksi's guidance in Microsoft Excel and Word in my undergraduate and graduate career have proved to be invaluable in the synthesis of this document.

Next, I would like to thank my fellow graduate students and friends I have made while at WVU. Graduate school would not have been as valuable or rewarding if not for the invaluable friendships I have made with those surrounding me. Specifically, I would like to thank Cory Gibbs for all the late nights working together on lab work and course work, especially the Tuesday nights at 3am struggling through Structural Dynamics. Andrew Wheeler and Andrew Cvetnick's efforts in the preparation of the experimental specimens cannot be understated and I cannot thank them enough. Laura Dalton's contribution to the editing of this thesis was greatly appreciated. I would like to acknowledge the efforts of Jerry Nestor in the Major Units Lab whose assistance during experimental testing was invaluable.

My friends and family's support during graduate school means the world to me. I would not have made it if not for their constant encouragement. Finally, I cannot thank enough my future wife, Danielle Poling, for without her constant sacrifices and editing, this thesis would not be possible. 


\section{TABLE OF CONTENTS}

ABSTRACT

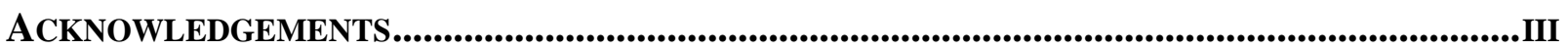

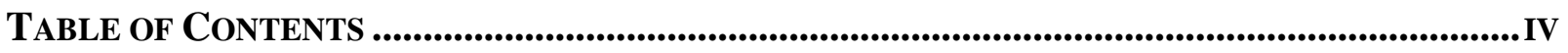

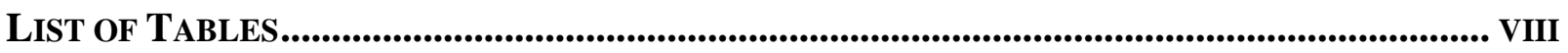

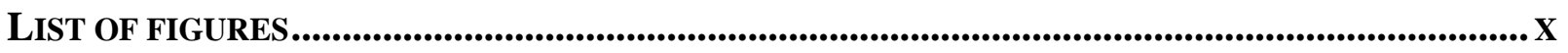

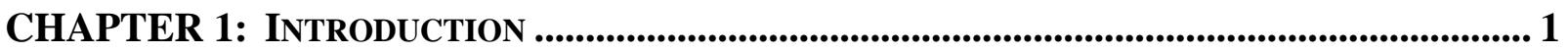

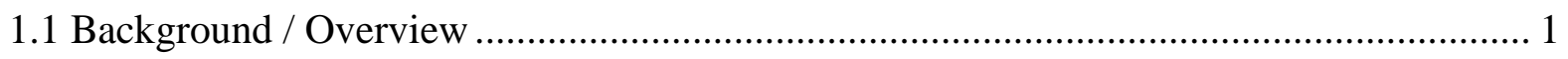

1.2 Project Scope \& Objectives ............................................................................. 1

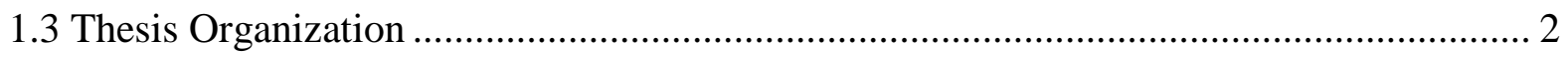

CHAPTER 2: LITERATURE REVIEW .................................................................................. 3

2.1 Introduction .......................................................................................................... 3

2.2 Accelerated Bridge Construction ......................................................................... 3

2.2.1 Geosynthetic Reinforced Soil-Integration Bridge System.................................... 4

2.2.2 Slide-In Bridge Construction ....................................................................... 5

2.2.3 Prefabricated Bridge Elements and Systems ................................................... 6

2.3 Previous Applications of Cold-Bent Steel Girders ................................................. 7

2.3.1 Prefabricated Press-Formed Steel T-Box Girder Bridge System (Taly \& Gangarao,

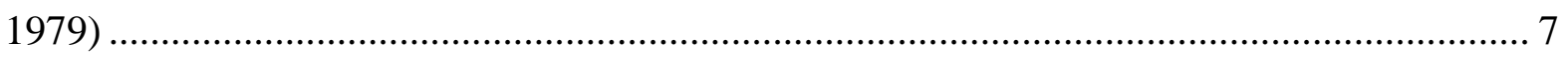

2.3.2 Composite Girders with cold Formed Steel U-sections (Nakamura, 2002) ................ 9

2.3.3 Folded Plate Girders (Developed at the University of Nebraska) .......................... 10

2.3.4 Texas Department of Transportation Rapid Economical Bridge Replacement.......... 11

2.3.5 MDOT Prefabricated Composite Steel Box-Girder Systems for Rapid Bridge

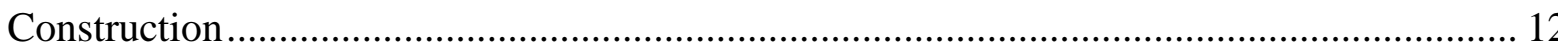


2.3.6 Con-Struct Prefabricated Bridge System ..................................................................... 13

2.4 Previous Research at WVU on Press-Brake-Formed Steel Tub Girders ............................ 14

2.4.1 Development and Feasibility Assessment of Shallow Press-Brake-Formed Steel Tub Girders for Short-Span Bridge Applications (Michaelson 2014)

2.4.2 Experimental Evaluation of Non-Composite Shallow Press-Brake-Formed Steel Tub

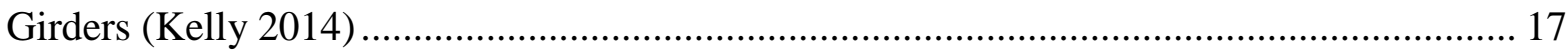

2.4.3 Evaluation of Modular Press-Brake-Formed Tub Girders with UHPC Joints

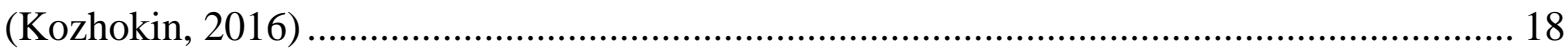

2.5 Current Implementations of Press-Brake-Formed Steel Tub Girders................................. 21

2.5.1 Amish Sawmill Bridge in Buchanan County, Iowa...................................................... 21

2.5.2 Cannelville Road Bridge in Muskingum County, Ohio................................................ 23

2.6 Corrosion Protection Systems.................................................................................. 24

2.6.1 Corrosion Process …………………………………......................................... 24

2.6.2 Painting Systems ................................................................................................... 27

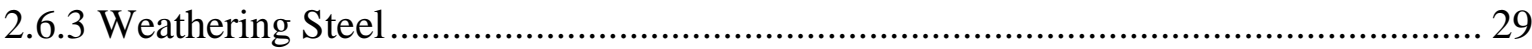

2.6.4 Hot-Dip Galvanization......................................................................................... 30

CHAPTER 3: TUB GIRDER DESIGN EXAMPLE ................................................................... 33

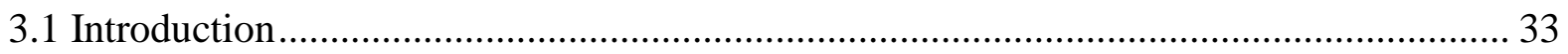

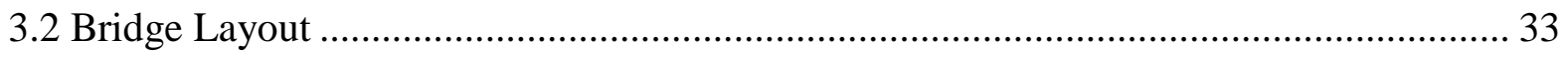

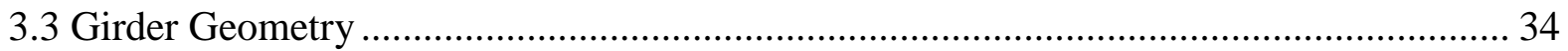

3.4 Loads \& Load Combinations ....................................................................................... 37

3.4.1 Component and Attachment Dead Load (DC).............................................................. 38

3.5 Multiple Presence Factors \& Live Load Distribution......................................................... 40

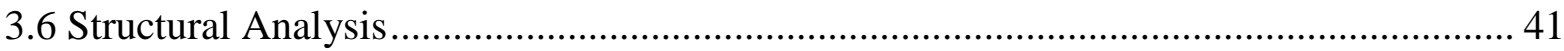

3.7 Limit State Evaluations.................................................................................................. 47 
3.7.1 Cross Section Proportion Limits (AASHTO Article 6.11.2) .................................... 47

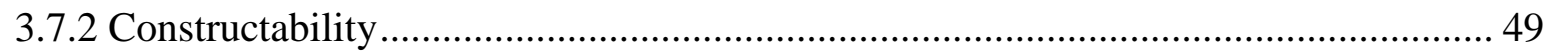

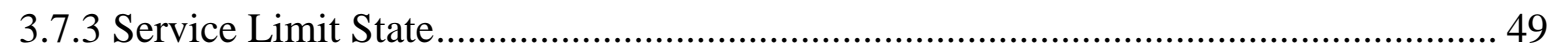

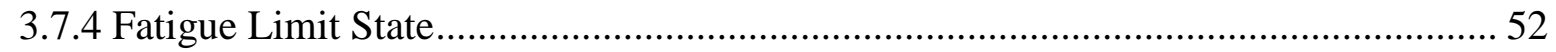

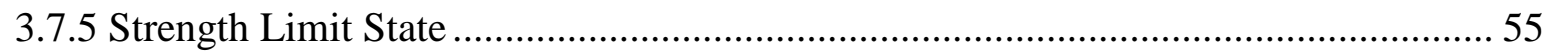

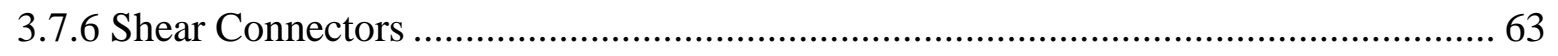

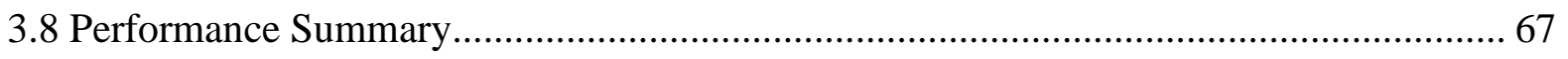

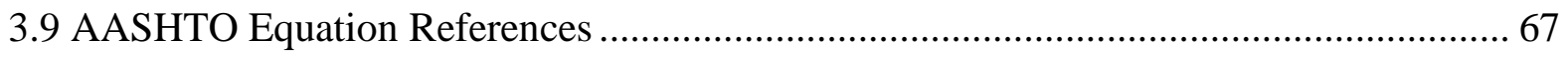

CHAPTER 4: EXPERIMENTAL TESTING .................................................................... 69

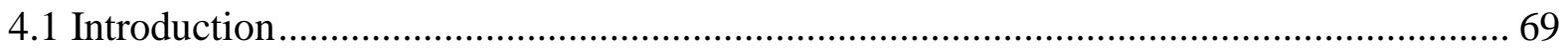

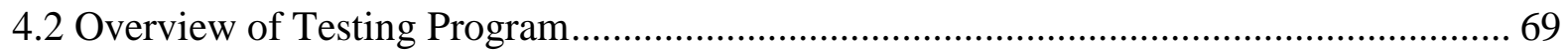

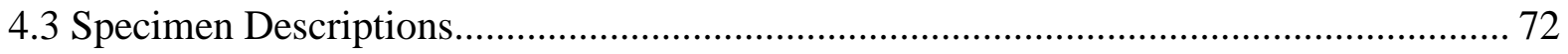

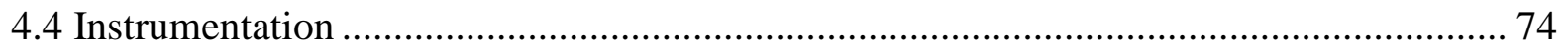

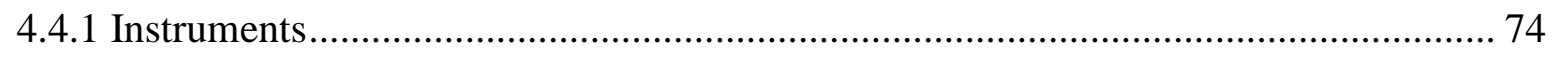

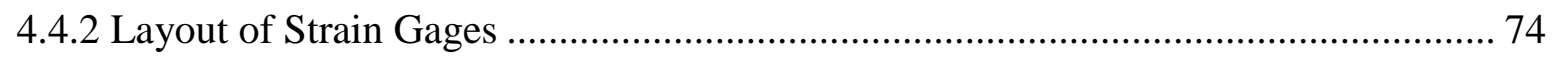

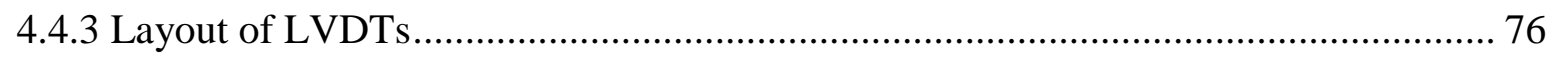

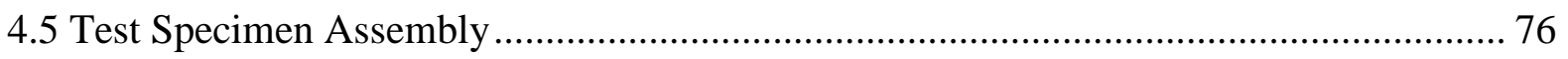

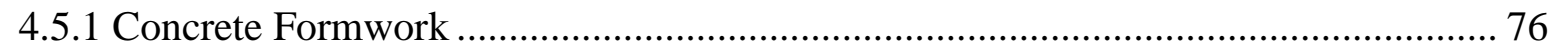

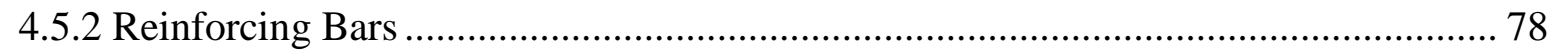

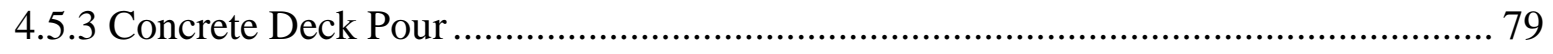

4.6 Load Configuration ........................................................................................ 81

4.7 Load Magnitude Determination ........................................................................... 82

4.7.1 Load Determination Overview ....................................................................... 82

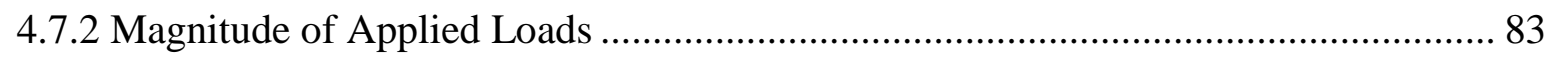

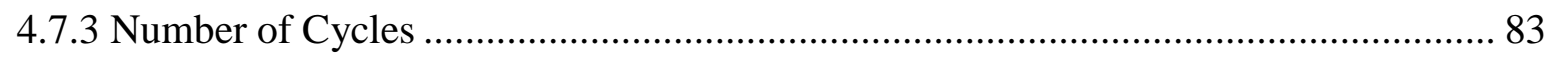




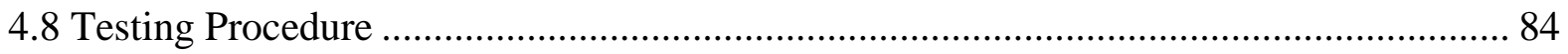

4.8.1 Procedure for Fatigue Testing................................................................... 84

4.8.2 Procedure for Test to Ultimate Failure ............................................................. 85

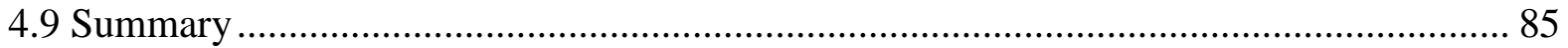

CHAPTER 5: EXPERIMENTAL TESTING RESULTS ................................................... 86

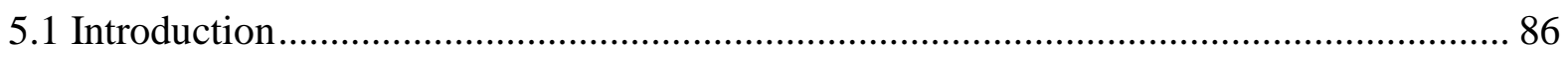

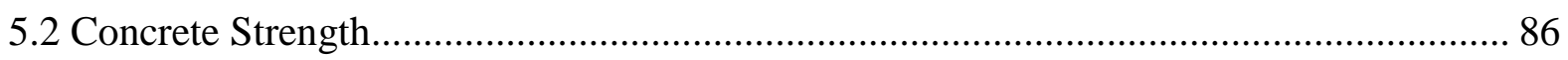

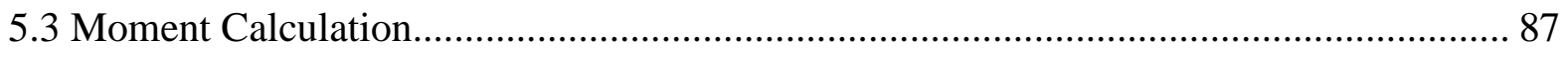

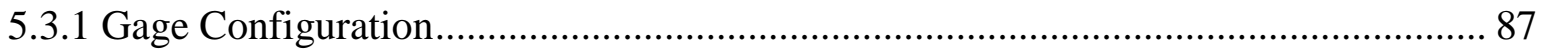

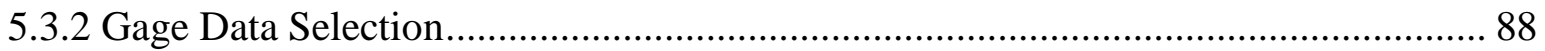

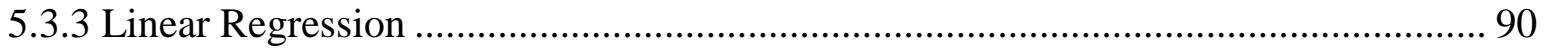

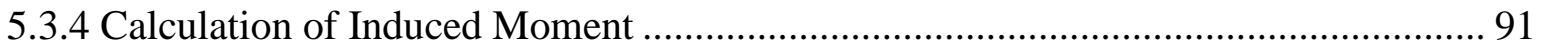

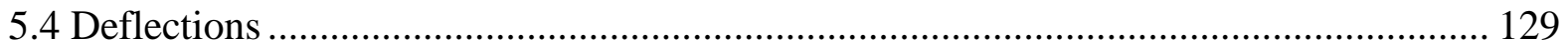

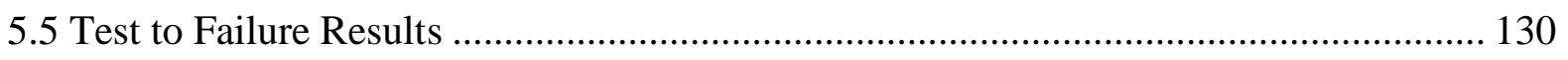

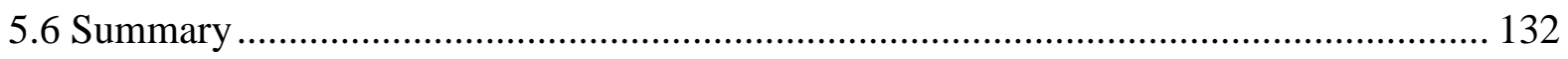

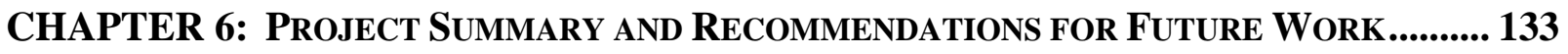

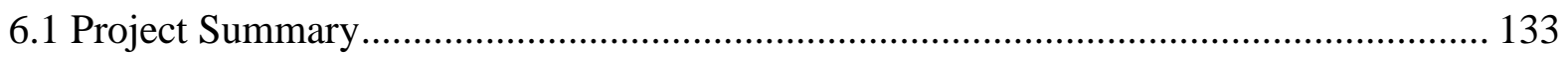

6.2 Recommendations for Continued Research.......................................................... 133

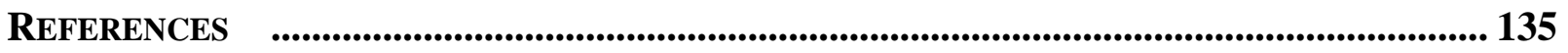

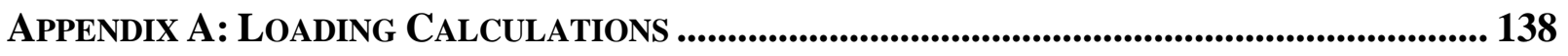

APPENDIX B: GAGE DATA....................................................................................................... 144

Original Raw Data From Uncoated Steel Specimen................................................... 144

Original Raw Data From Galvanized Steel Specimen.................................................. 153 


\section{LIST OF TABLES}

Table 3.1: Non-Composite Section Properties ............................................................................ 36

Table 3.2: Short Term Composite Section Properties .............................................................. 36

Table 3.3: Long Term Composite Section Properties..................................................................... 36

Table 3.4 Multiple Presence Factors (AASHTO, 2014) ............................................................... 40

Table 3.5: Unfactored/Undistributed Moments (ft-kip)............................................................ 42

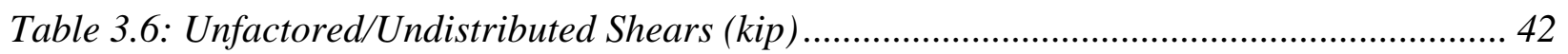

Table 3.7: Unfactored/Undistributed Deflections (in).................................................................... 43

Table 3.8: Unfactored/Distributed Moments (ft-kip).................................................................... 43

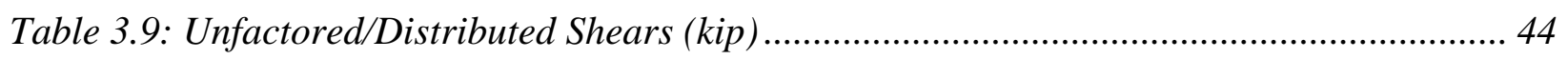

Table 3.10: Strength I Moments (ft-kip) .................................................................................. 44

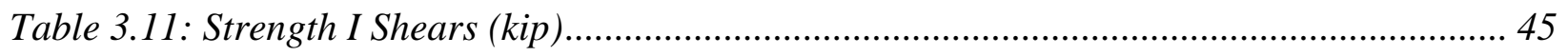

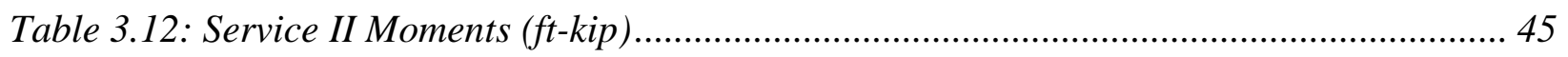

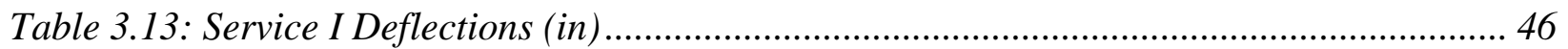

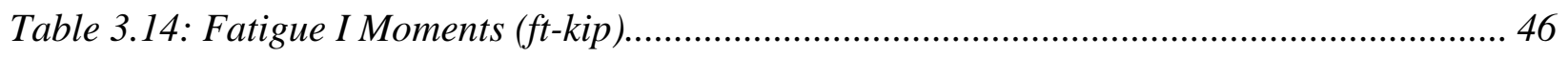

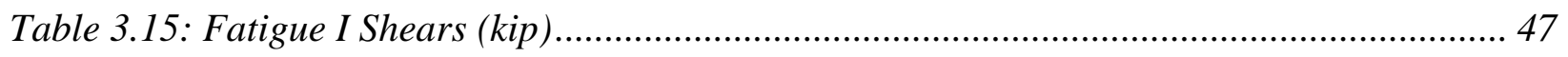

Table 3.16: Calculation of Vertical Shear Force Range ................................................................ 64

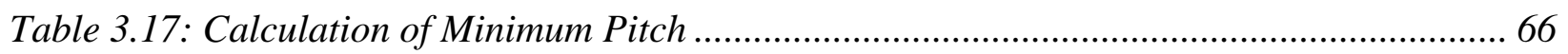

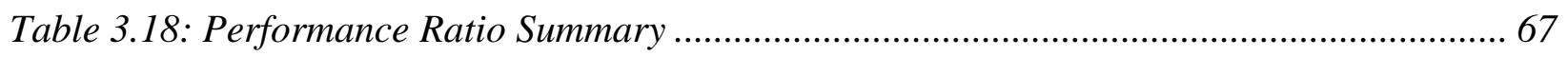

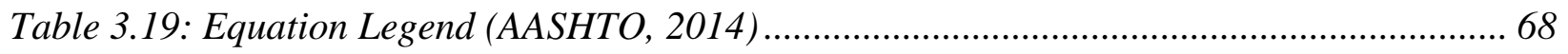

Table 4.1: Press-Brake-Formed Tub Girder Non-Composite Section Properties ........................ 74

Table 5.1: Least Squares and Percent Error for Uncoated Steel Specimen.................................. 93

Table 5.2: Least Squares and Percent Error for Galvanized Steel Specimen ................................ 94

Table 5.3: Load Test Summary at 0 Cycles .................................................................................. 95

Table 5.4: Load Test Summary at 100,000 Cycles ……………………………………….......... 96

Table 5.5: Load Test Summary at 200,000 Cycles .................................................................. 97

Table 5.6: Load Test Summary at 300,000 Cycles ....................................................................... 98

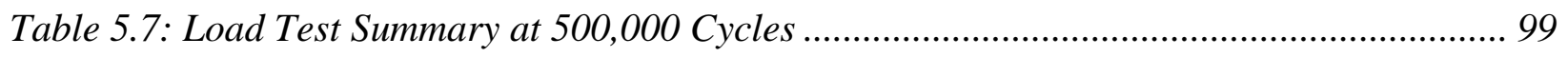

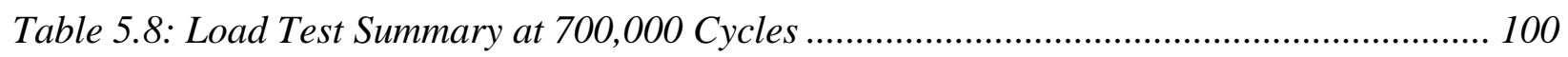

Table 5.9: Load Test Summary at 900,000 Cycles .................................................................... 101 
Table 5.10: Load Test Summary at 1,100,000 Cycles .............................................................. 102

Table 5.11: Load Test Summary at 1,300,000 Cycles ................................................................. 103

Table 5.12: Load Test Summary at 1,500,000 Cycles ................................................................ 104

Table 5.13: Load Test Summary at 1,700,000 Cycles ........................................................... 105

Table 5.14: Load Test Summary at 1,900,000 Cycles ............................................................. 106

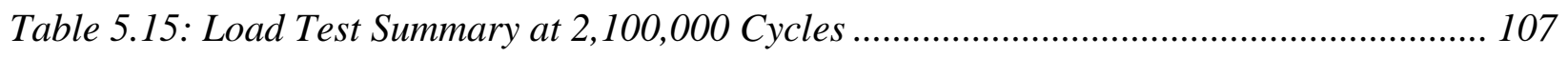

Table 5.16: Load Test Summary at 2,300,000 Cycles ................................................................ 108

Table 5.17: Load Test Summary at 2,500,000 Cycles ................................................................. 109

Table 5.18: Load Test Summary at 2,700,000 Cycles ..................................................................... 110

Table 5.19: Load Test Summary at 2,900,000 Cycles ........................................................... 111

Table 5.20: Load Test Summary at 0 Cycles ............................................................................... 112

Table 5.21: Load Test Summary at 100,000 Cycles ............................................................. 113

Table 5.22: Load Test Summary at 200,000 Cycles .................................................................. 114

Table 5.23: Load Test Summary at 300,000 Cycles .............................................................. 115

Table 5.24: Load Test Summary at 500,000 Cycles ................................................................... 116

Table 5.25: Load Test Summary at 700,000 Cycles …………………………..................... 117

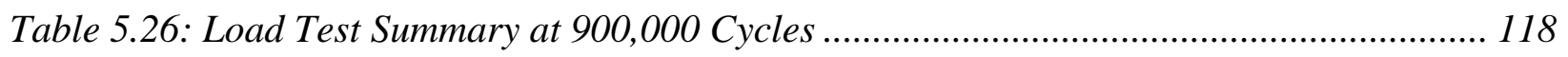

Table 5.27: Load Test Summary at 1,100,000 Cycles ............................................................. 119

Table 5.28: Load Test Summary at 1,300,000 Cycles .............................................................. 120

Table 5.29: Load Test Summary at 1,500,000 Cycles ........................................................... 121

Table 5.30: Load Test Summary at 1,700,000 Cycles ............................................................... 122

Table 5.31: Load Test Summary at 1,900,000 Cycles ............................................................. 123

Table 5.32: Load Test Summary at 2,100,000 Cycles ............................................................ 124

Table 5.33: Load Test Summary at 2,300,000 Cycles .............................................................. 125

Table 5.34: Load Test Summary at 2,500,000 Cycles ................................................................ 126

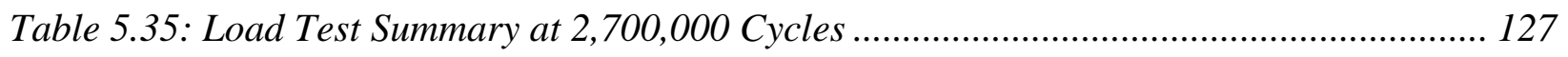

Table 5.36: Load Test Summary at 2,900,000 Cycles ............................................................. 128

Table 5.37: Summary of Uncoated Steel Specimen Deflections ................................................... 129

Table 5.38: Summary of Galvanized Steel Specimen Deflections ............................................. 130

Table A.1: Summary of Moments for Uncoated Steel Specimen by Individual Components ..... 142

Table A.2: Summary of Moments for Galvanized Steel Specimen by Individual Components... 143 


\section{LIST OF FIGURES}

Figure 2.1: Typical GRS-IBS Cross Section (Adams et al., 2011) .............................................. 5

Figure 2.2: Overhead View of West Mesquite SIBC Project, Nevada (FHWA, 2013)................. 6

Figure 2.3: Taly and Gangarao’s Proposed All-Steel Section (Taly \& Gangarao, 1979)............ 8

Figure 2.4: Taly and Gangarao’s Composite Section (Taly \& Gangarao, 1979)........................ 9

Figure 2.5: Nakamura's Proposed Bridge System (Nakamura, 2002)..................................... 10

Figure 2.6: System Proposed at the University of Nebraska (Burner, 2010)............................ 11

Figure 2.7: TxDOT Trapezoidal Box Girder for Rapid Bridge Replacement (Chandar et al., 2010)

.

Figure 2.8: MDOT Proposed Bridge System (Burgueno \& Pavlich, 2008).............................. 13

Figure 2.9: Typical Interior Con-Struct Cross Section ......................................................... 14

Figure 2.10: Design Comparison of 84” Wide Plate (Michaelson, 2014)................................ 15

Figure 2.11: Comparison of Experimental and Analytical Results (Michaelson, 2014)............. 16

Figure 2.12: Web Inclinations (Kelly, 2014) ....................................................................... 17

Figure 2.13: Lateral Torsional Buckling (Kelly, 2014).......................................................... 18

Figure 2.14: Concrete Surface after Wire-Brushing (Kozhokin, 2016) ................................... 19

Figure 2.15: Shear Crack Propagated Across UHPC Joint (Kozhokin, 2016).......................... 20

Figure 2.16: New Amish Sawmill Bridge (Gibbs, 2017) ........................................................ 21

Figure 2.17: FEA v. Experimental v. AASHTO LLDFs (Gibbs, 2017) ..................................... 22

Figure 2.18: Modular SPS Deck/Tub Girder System Being Lowered in Place.......................... 23

Figure 2.19: Schematic Representation of the Corrosion Process (Corus, 2004) ...................... 24

Figure 2.20: Galvanic Series (Ghavamian et al., 2015)......................................................... 26

Figure 2.21: Conventional Protective Paint System (NPL, 2000)............................................ 27

Figure 2.22: Comparison between 2-Coat and 3-Coat Systems (Olsen et al., 2017)................. 29

Figure 2.23: Dipping of Steel in Molten Zinc (American Galvanizers Association, 2018).......... 31

Figure 2.24: Cross Section of Galvanized Steel Coating (American Galvanizers Association, 2018)

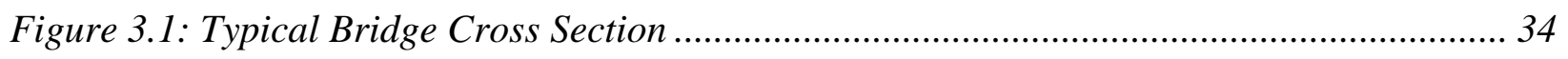

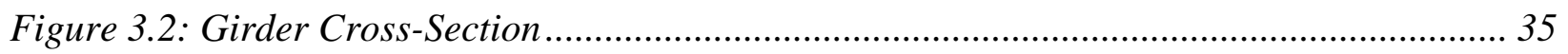

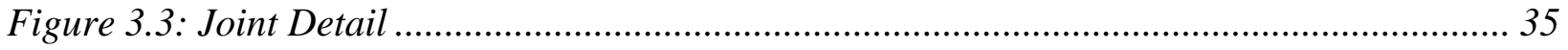


Figure 3.4: Live Load Deflection Limits (AASHTO, 2014).................................................. 52

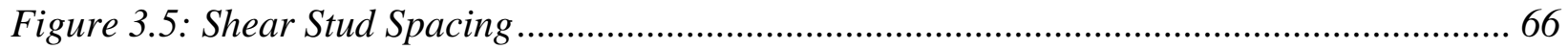

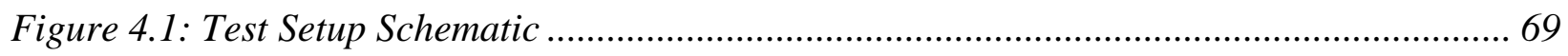

Figure 4.2: Isometric View of Typical Test Setup ............................................................... 70

Figure 4.3: View of Pinned Boundary Condition ................................................................. 71

Figure 4.4: View of Roller Boundary Condition ................................................................ 71

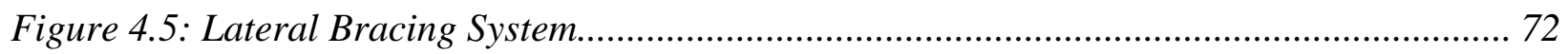

Figure 4.6: Press-Brake Tub Girder Cross Section ............................................................. 73

Figure 4.7: Press-Brake Tub Girder with End Diaphragm..................................................... 73

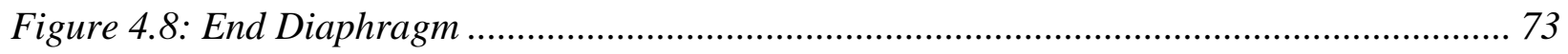

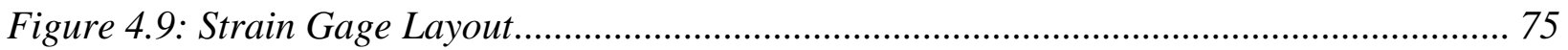

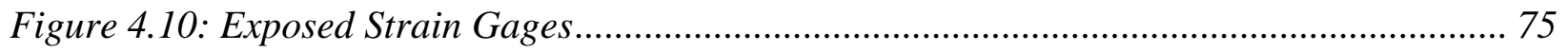

Figure 4.11: Covered Strain Gages................................................................................... 76

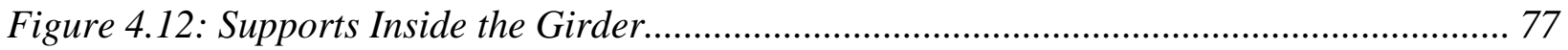

Figure 4.13: Completed Concrete Formwork …................................................................... 78

Figure 4.14: Placement of Reinforcing Steel....................................................................... 79

Figure 4.15: Concrete Bucket Lowering into Position ............................................................. 80

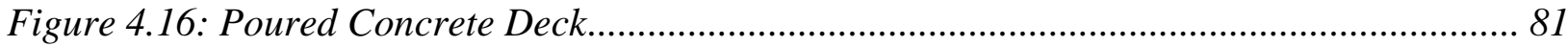

Figure 4.17: Load Applied to the System............................................................................. 82

Figure 4.18: Typical Failure Mode for Composite Specimens................................................... 85

Figure 5.1: Experimental vs. Theoretical Loads at 0 Cycles ................................................ 95

Figure 5.2: Experimental vs. Theoretical Loads at 100,000 Cycles ........................................ 96

Figure 5.3: Experimental vs. Theoretical Loads at 200,000 Cycles ......................................... 97

Figure 5.4: Experimental vs. Theoretical Loads at 300,000 Cycles ....................................... 98

Figure 5.5: Experimental vs. Theoretical Loads at 500,000 Cycles ......................................... 99

Figure 5.6: Experimental vs. Theoretical Loads at 700,000 Cycles ...................................... 100

Figure 5.7: Experimental vs. Theoretical Loads at 900,000 Cycles ....................................... 101

Figure 5.8: Experimental vs. Theoretical Loads at 1,100,000 Cycles .................................... 102

Figure 5.9: Experimental vs. Theoretical Loads at 1,300,000 Cycles ................................... 103

Figure 5.10: Experimental vs. Theoretical Loads at 1,500,000 Cycles .................................. 104

Figure 5.11: Experimental vs. Theoretical Loads at 1,700,000 Cycles ................................. 105 
Figure 5.12: Experimental vs. Theoretical Loads at 1,900,000 Cycles .................................. 106

Figure 5.13: Experimental vs. Theoretical Loads at 2,100,000 Cycles .................................. 107

Figure 5.14: Experimental vs. Theoretical Loads at 2,300,000 Cycles .................................. 108

Figure 5.15: Experimental vs. Theoretical Loads at 2,500,000 Cycles .................................. 109

Figure 5.16: Experimental vs. Theoretical Loads at 2,700,000 Cycles .................................. 110

Figure 5.17: Experimental vs. Theoretical Loads at 2,900,000 Cycles .................................. 111

Figure 5.18: Experimental vs. Theoretical Loads at 0 Cycles ............................................... 112

Figure 5.19: Experimental vs. Theoretical Loads at 100,000 Cycles ..................................... 113

Figure 5.20: Experimental vs. Theoretical Loads at 200,000 Cycles ..................................... 114

Figure 5.21: Experimental vs. Theoretical Loads at 300,000 Cycles ..................................... 115

Figure 5.22: Experimental vs. Theoretical Loads at 500,000 Cycles .................................... 116

Figure 5.23: Experimental vs. Theoretical Loads at 700,000 Cycles ..................................... 117

Figure 5.24: Experimental vs. Theoretical Loads at 900,000 Cycles ...................................... 118

Figure 5.25: Experimental vs. Theoretical Loads at 1,100,000 Cycles .................................. 119

Figure 5.26: Experimental vs. Theoretical Loads at 1,300,000 Cycles .................................. 120

Figure 5.27: Experimental vs. Theoretical Loads at 1,500,000 Cycles .................................. 121

Figure 5.28: Experimental vs. Theoretical Loads at 1,700,000 Cycles .................................. 122

Figure 5.29: Experimental vs. Theoretical Loads at 1,900,000 Cycles ................................. 123

Figure 5.30: Experimental vs. Theoretical Loads at 2,100,000 Cycles ................................... 124

Figure 5.31: Experimental vs. Theoretical Loads at 2,300,000 Cycles .................................. 125

Figure 5.32: Experimental vs. Theoretical Loads at 2,500,000 Cycles ................................. 126

Figure 5.33: Experimental vs. Theoretical Loads at 2,700,000 Cycles .................................. 127

Figure 5.34: Experimental vs. Theoretical Loads at 2,900,000 Cycles ................................. 128

Figure 5.35: Load-Deflection Data from Flexural Testing of Uncoated Steel Specimen .......... 131

Figure 5.36: Bottom Flange Load-Strain Data from Flexural Testing Uncoated Steel Specimen

Figure A.1: HL-93 Fatigue Truck Placement................................................................... 138

Figure A.2: HL-93 Truck Placement ............................................................................... 140

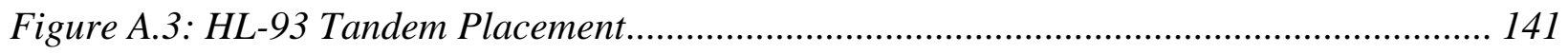

Figure A.4: HL-93 Lane Model ..................................................................................... 142 


\section{CHAPTER 1: INTRODUCTION}

\subsection{BACKGROUND / OVERVIEW}

A technical group within the Short Span Steel Bridge Alliance (SSSBA) developed the concept of modular shallow press-brake-formed steel tub girders. The SSSBA is a group of bridge and culvert industry leaders (including steel manufacturers, fabricators, service centers, coaters, researchers, and representatives of related associations and government organizations) who have joined together to provide educational information on the design and construction of short span steel bridges in installations of up to 140 feet in length. The concept of modular shallow pressbrake-formed steel tub girders consists of cold-bending standard mill plate widths and thicknesses to form a trapezoidal box girder. The steel plate can consist of either uncoated or galvanized steel. However, comparison of the fatigue performance between cold-bent tub girders consisting of different coating options has not been conducted. When the steel plate is bent into the trapezoidal box girder using a press-brake, residual stresses are created in the bends. To evaluate potential weakening caused by the galvanization process, two full scale fatigue tests of two different 38 foot cold-bent press-brake formed steel tub girders, one girder being uncoated steel and the other being hot-dip galvanized, were performed at West Virginia University.

\subsection{Project Scope \& OBJectives}

The scope of this thesis was to test two composite modular press-brake-formed tub girders, one being uncoated steel and the other being galvanized. Additionally, a design example using press-brake-formed tub girders selected from optimized designs by Michaelson (2014) is included. Specifically, these objectives were assessed using the following four steps:

- A brief discussion of prior work done on press-brake-formed tub girders and their place in accelerated bridge construction

- A design example using tub girders utilizing the AASHTO LRFD Bridge Design Specifications (2014), demonstrating applications of critical limit states in press-brakeformed tub girders 
- An explanation of the research methods and laboratory testing conducted on the different specimens, including a full description of the experimental investigation

- A summary of results and conclusions comparing the experimental data collected on the uncoated steel specimen and the galvanized steel specimen

\subsection{Thesis Organization}

A brief overview of the organization of this thesis is as follows:

- $\quad$ Chapter 2:

o This chapter will provide a general overview of accelerated bridge construction methods, with a more specific investigation into the research conducted on coldbent tub girder applications at West Virginia University and elsewhere. Additionally, a summary of corrosion prevention systems is provided.

- $\quad$ Chapter 3:

o This chapter contains a design example on press-brake tub girders. This includes the calculation of composite section properties and the AASHTO LRFD limit states that needed to be addressed.

- $\quad$ Chapter 4:

o This chapter discusses the research methods employed during the testing program. A detailed explanation of the assembly of the composite girder and loading description is provided within.

- $\quad$ Chapter 5:

o This chapter discusses the results obtained during testing. Methods used for data analysis and material properties are contained within.

- Chapter 6:

o This chapter provides a summary of the project and recommendations for future work.

- Appendix A:

o This appendix describes the calculations of the Service II and Fatigue I moments.

- Appendix B:

o This appendix documents the experimental gage data obtained during the testing. 


\section{CHAPTER 2: LITERATURE REVIEW}

\subsection{INTRODUCTION}

This chapter presents a general overview of previous research and implementation of coldbent tub girders and their place in accelerated bridge construction. The literature review starts by discussing accelerated bridge construction and the methods proven popular to implement. A summary of previous research performed on cold-bent tub girders is presented, concluding with an in-depth review of work done at West Virginia University. Section 2.5 covers the field implementations and concurrent research performed on press-brake-formed steel tub girder bridges. Section 2.6 discusses the different corrosion protection systems, including painting, hotdip galvanizing, and the use of weathering steel.

\subsection{ACCElERAted BRIDGe Construction}

The Every Day Counts (EDC) program was launched in 2009 by the Federal Highway Administration (FHWA) in conjunction with the American Association of State and Highway Transportation Officials (AASHTO) with the goal to accelerate the delivery of highway projects and to address the obstacles faced by limited budgets (FHWA Pamphlet, 2014). The goal of EDC is to identify and rapidly deploy innovations to shorten the project delivery procedure, improve highway safety, reduce congestion, and promote environmental sustainability. Every two years, a summit is held between the FHWA, state and local agencies, and industry stakeholders to collaboratively select innovations. State and local agencies then focus on the innovations that work best for their programs' needs and commit to finding opportunities to implement these innovations.

An innovation promoted for the 2013-2014 cycle was Accelerated Bridge Construction $(\mathrm{ABC}) . \mathrm{ABC}$ is a style of bridge construction, which uses innovative planning, design, materials, and construction methods to safely and cost-effectively reduce onsite construction time when building new bridges or replacing and restoring existing bridges (Culmo, 2011). ABC has become highly desirable to many states’ Departments of Transportation. 
When the modern highway network was under construction, most projects focused on new infrastructure, as opposed to replacing old infrastructure. These projects typically did not have traffic acting along the path which required redirection and did not occur in physically constrained spaces. This allowed more use of shored formwork and was not an inconvenience to the public for multi-month to multi-year construction projects. As a significant number of these original bridges approach and surpass their service lives, rapid bridge replacement has become a focus in the bridge construction industry. Many practices utilized in the original construction of these aging bridges are antiquated and no longer suitable or economical for current needs.

The use of ABC methods has many benefits, the most important being improved safety. Worker and motorist safety has improved by shortening travel lane restrictions by performing most construction away from traffic. Reduction of on-site construction shortens the total project delivery time, which can greatly reduce total project cost (FHWA Pamphlet, 2014). Off-site construction in a climate-controlled setting has improved the quality of bridge members. Temperature, humidity, rain, snow, and other environmental factors can have adverse effects on construction elements. To reduce environmental impacts, the EDC initiative included three particular ABC technologies in its second round of initiatives: Geosynthetic Reinforced Soil Integration Bridge Systems, Slide-In Bridge Construction, and Prefabricated Bridge Elements and Systems.

\subsubsection{Geosynthetic Reinforced Soil-Integration Bridge System}

Geosynthetic Reinforced Soil Integrated Bridge System (GRS-IBS) is a rapid, inexpensive method of bridge support unification of the roadway and the superstructure to create a jointless interface between the bridge and the approach (Adams et al., 2011). The three components of GRSIBS are the reinforced soil foundation (RSF), the abutment, and the integrated approach. The RSF consists of compacted granular soil encompassed in a geotextile fabric. Using geosynthetic reinforcement in soil is an alternative to deep foundations on sub-optimal material. The abutment used in this system utilizes compacted fill with closely spaced geosynthetic material and is quicker than conventional approach slabs to install because it is placed directly on the RSF without a joint and without cast-in-place concrete. GRS-IBS is used in the approach to the bridge to transition to 
the superstructure. This use of the same material in the abutment and the approach smooths the transition by removing differential settlement. A GRS-IBS cross section is seen in Figure 2.1.

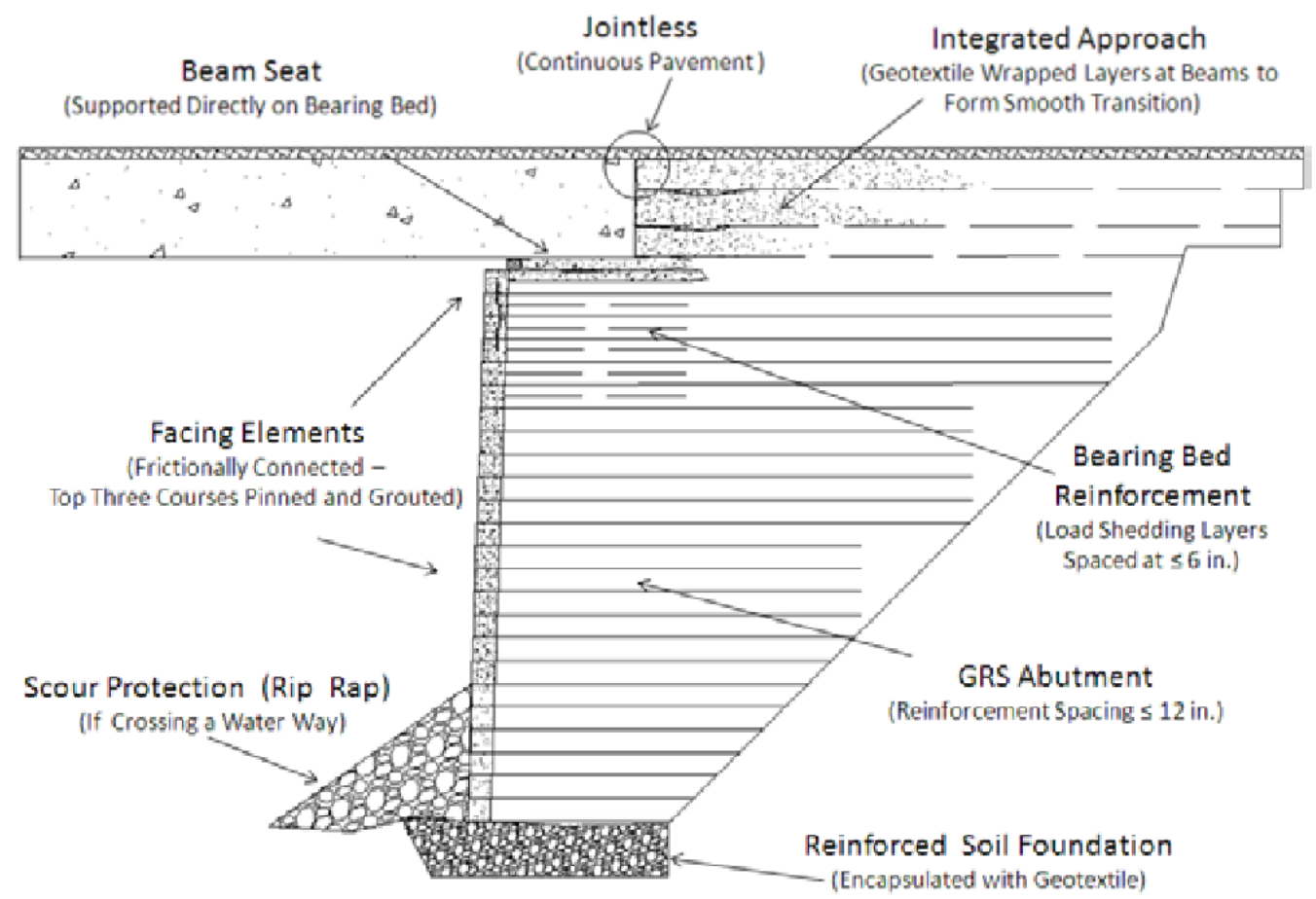

Figure 2.1: Typical GRS-IBS Cross Section (Adams et al., 2011)

\subsubsection{Slide-In Bridge Construction}

Slide-In Place Bridge Construction (SIBC) allows construction of a new bridge while maintaining traffic on the existing bridge during the majority of construction (FHWA, 2013). Temporary supports are constructed adjacent to the existing bridge, and the new bridge is built on these supports, as seen in Figure 2.2. Once construction of the new bridge is complete, the old bridge is closed and demolished or moved to a staging area for demolition and removal. The new bridge slides into place, approach tie-ins are constructed, and traffic reopened.

Some of the benefits of using SIBC include enhanced safety, potential reduced project costs, and improved constructability. Safety is improved by reducing the interaction between construction workers and vehicular traffic because typical phased construction requires construction of one half of the bridge, opening it to traffic, and then construction of the second 
half. SIBC allows construction of the entire bridge at once, reducing the time of mobilization, concrete curing, and other phases of conventional construction. Constructability improves because more room for girders, concrete placement, and equipment access away from constant traffic are provided.

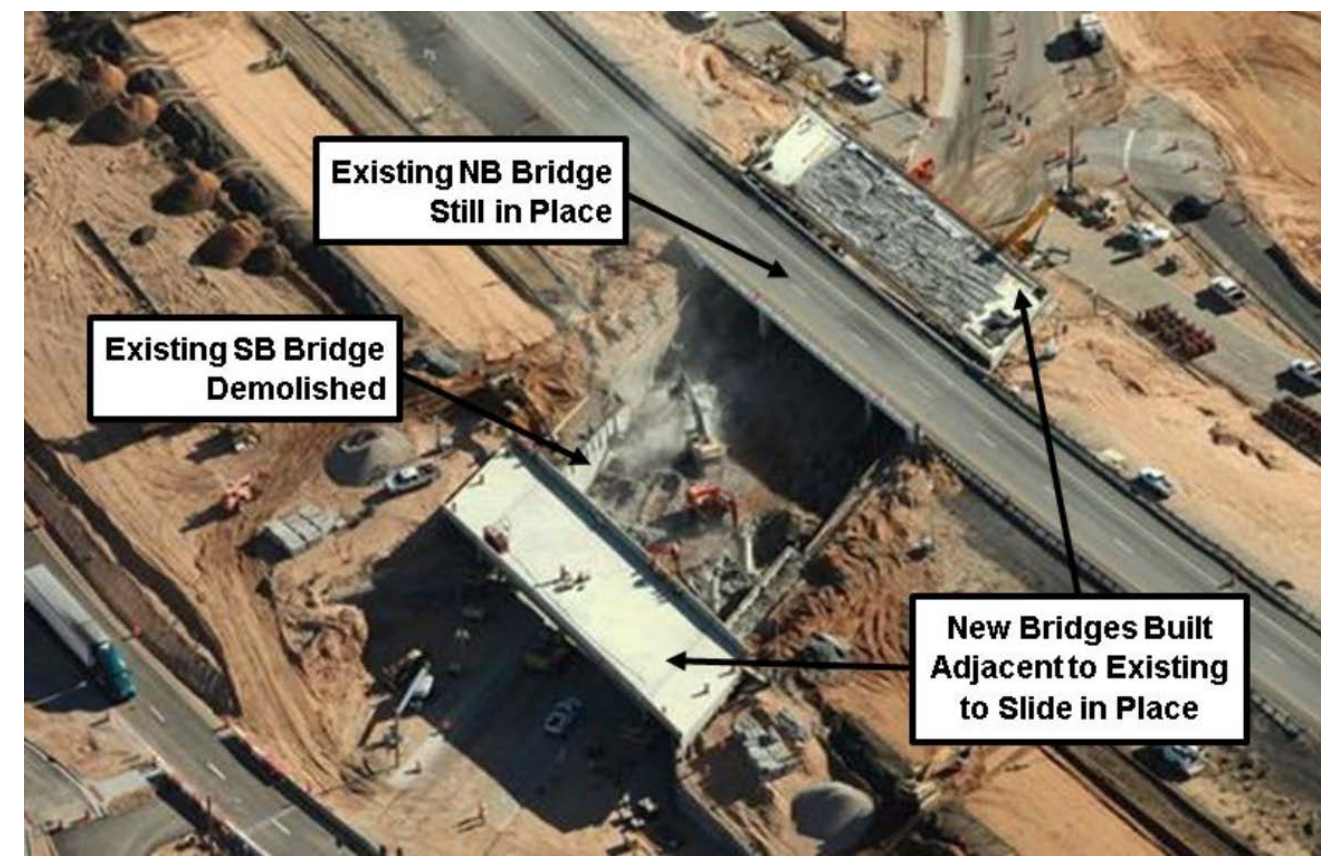

Figure 2.2: Overhead View of West Mesquite SIBC Project, Nevada (FHWA, 2013)

\subsubsection{Prefabricated Bridge Elements and Systems}

Prefabricated Bridge Elements and Systems (PBES) is the concept of bridge design and construction where most or all bridge components are fabricated off-site and only need to be shipped to and assembled at the construction site. The ultimate goal of PBES and ABC is to reduce construction impacts on the public. Expedient construction greatly reduces detours around the construction site and mitigate environmental effects. Off-site construction of all components necessary to build the bridge prior to on-site installation reduces time lost to conventional construction practices. Completing the majority of construction off site removes the need for onsite typical constructional aspects and wait time regarding curing.

In addition to reduced on-site construction time, PBES allows fabrication in a controlled environment, which inherently improves construction quality because bridge components are not 
exposed to weather during construction. This approach affords faster construction of prefabricated modules because specialized workers will be able to use formwork multiple times instead of rebuilding forms each time an element needs reproduced. PBES also improves safety of workers by reducing time exposed to traffic while working.

\subsection{Previous Applications of Cold-Bent Steel Girders}

Prefabricated steel tub girders have seen a resurgence in popularity over the last few years, but they are not a new technology. Prefabricated composite tub girders were a proposed solution as early as the 1970s. Specifically, as ABC has come to the forefront of bridge design, tub girders have shown a potential for short span steel bridge applications as they can be economical and competitive at spans under 60 feet. Several other researchers have conducted studies focused on economical and rapid bridge construction utilizing cold-bent steel tub girders.

\subsubsection{Prefabricated Press-Formed Steel T-Box Girder Bridge System (Taly \& Gangarao, 1979)}

Taly and Gangarao (1979) proposed a design for a set of cold-formed box girders suitable for spans up to 65 feet. Cold-formed girders are created by bending cold plate steel in a large capacity press-brake with the inside bend radius equal to five times the thickness of the plate. The all steel design had a stem of a trapezoidal box cold-formed from a 3/8 inch thick A-36 steel plate welded to a 3/8 inch thick steel top flange (Figure 2.3). This modular system could transfer load to adjacent girders through continuous welds provided at the junctions of the flanges. The advantages of such a system include, but are not limited to, high torsional stiffness of closed sections, increased effectiveness in distributing a load, and increased effectiveness for bridges on horizontal curves. 


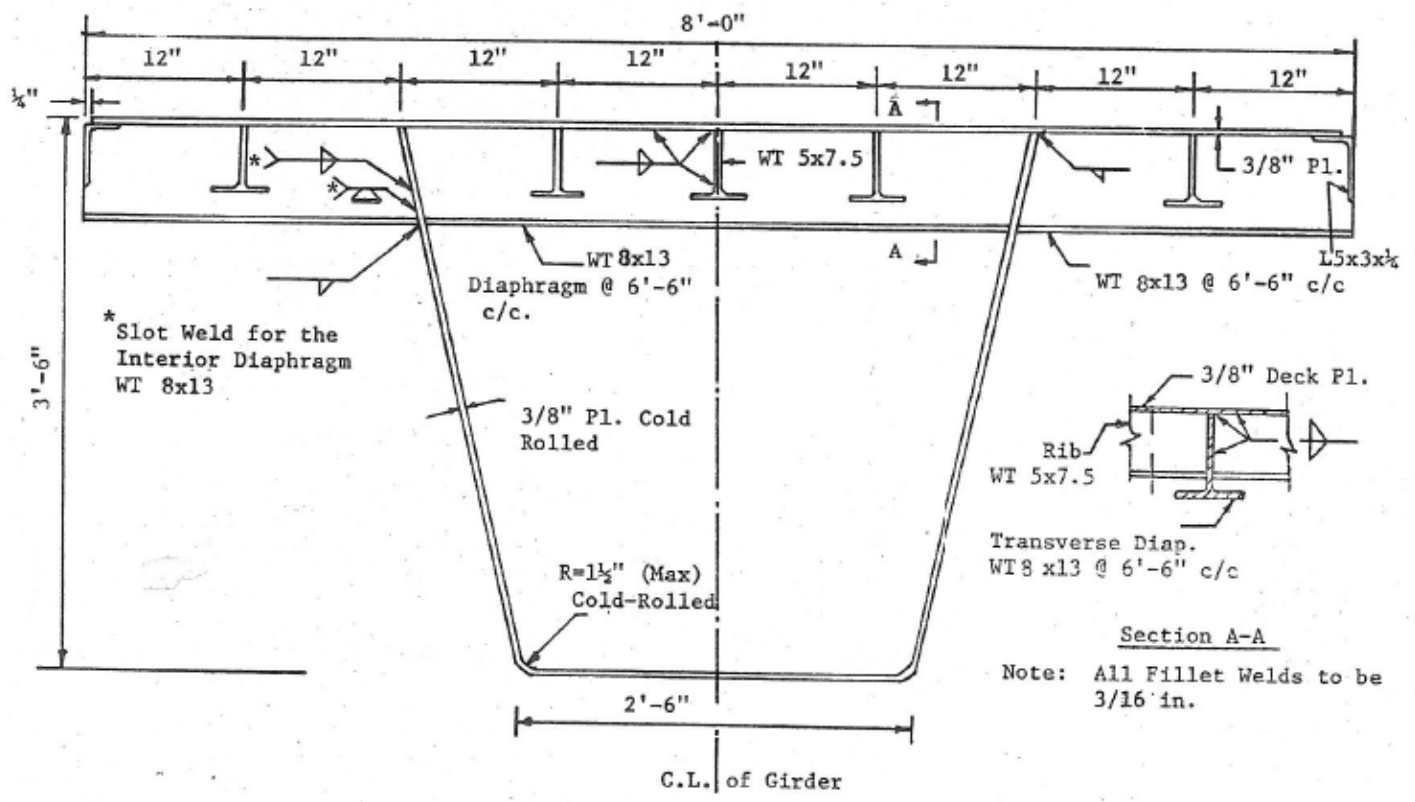

Figure 2.3: Taly and Gangarao's Proposed All-Steel Section (Taly \& Gangarao, 1979)

The other major advantage of this system is its ability to be constructed off site. The superstructure is fabricated in pieces under controlled conditions so quality of the individual members and structure as a whole increases. A cold-bent system, opposed to a system of welded plates in the form of a box, reduces the amount of fabrication by eliminating another step in the construction process. The low weight of the all steel system, approximately 11 tons for a 65 foot long girder with a depth of 42 inches, allows the use of low capacity equipment for handling, transportation, and erection.

An alternative to the all steel system was proposed by Taly and Gangarao using a 5 inch thick precast, prestressed concrete deck instead of a 3/8 inch thick steel plate as seen in Figure 2.4. Composite action would be developed through shear studs welded to the top flanges of the coldbent section. At the time, the AASHTO specifications did not provide design criteria for the design of members using a press brake or composite box girders. Therefore, the researchers evaluated their designs against the 1977 American Iron and Steel Institute (AISI) specifications. 


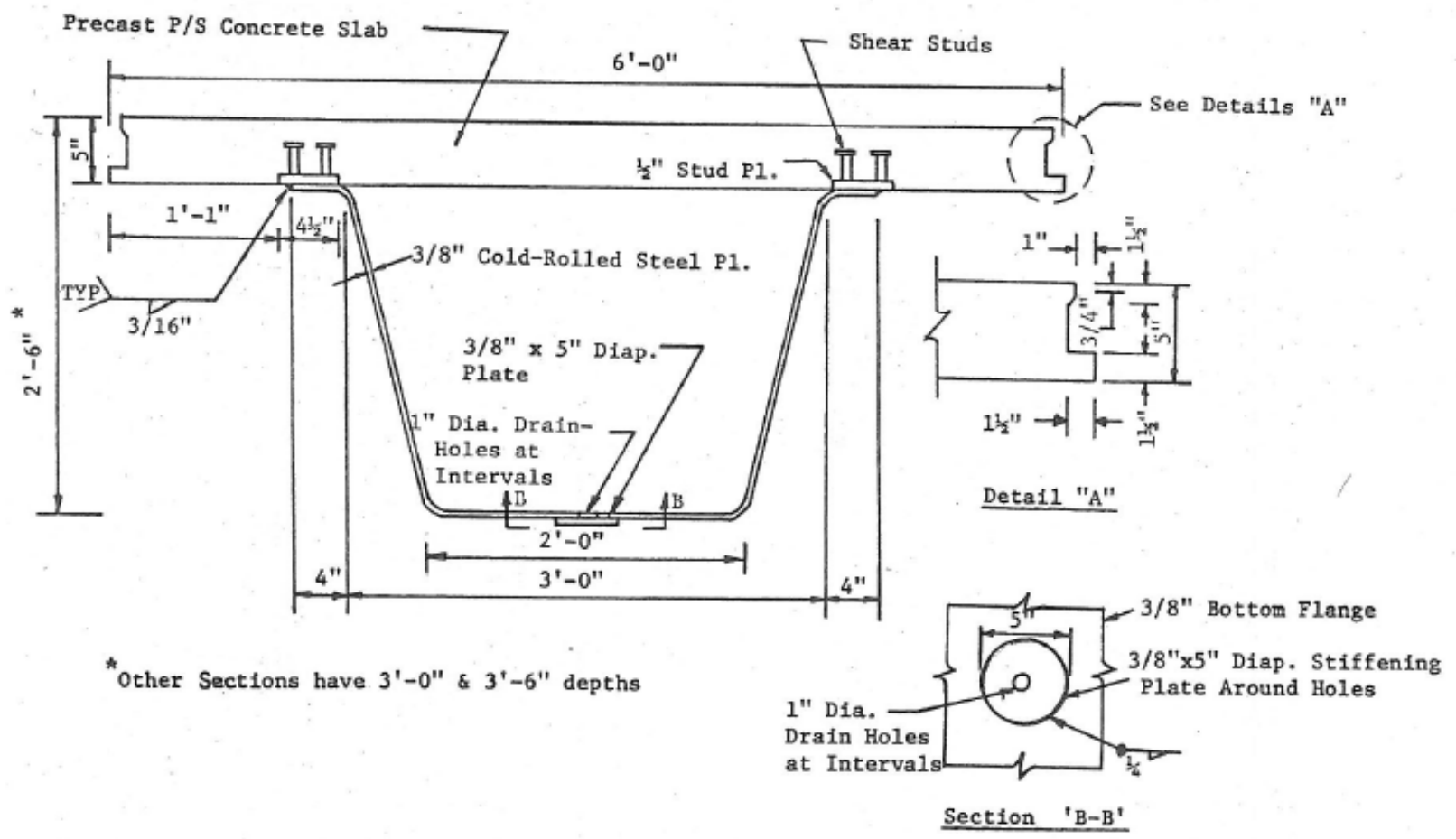

Figure 2.4: Taly and Gangarao's Composite Section (Taly \& Gangarao, 1979)

\subsubsection{Composite Girders with cold Formed Steel U-sections (Nakamura, 2002)}

Nakamura (2002) envisioned a continuous multi-span system utilizing a cold-bent steel girder with a reinforced concrete deck. The system behaves as a typical composite section over span centers but is in negative bending over the intermediate supports of a continuous girder. This negative bending places the reinforced concrete deck in tension and creates potential for buckling of the bottom flange over the support.

To overcome this susceptibility of buckling, the U-section is filled with concrete and prestressed by prestressed concrete bars to increase the strength against the negative bending moment. Typical prestressed girders require formwork and scaffolding to pour the concrete but these USections act as a mold, which further reduces fabrication costs. This concrete over the support increases the vertical reaction over the pier but does not increase the moment because the concrete is poured over the intermediate supports and not over midspans. Figure 2.5 shows Nakamura's proposed bridge system with an exposed cross-section over a midspan with concrete only in the deck section. 


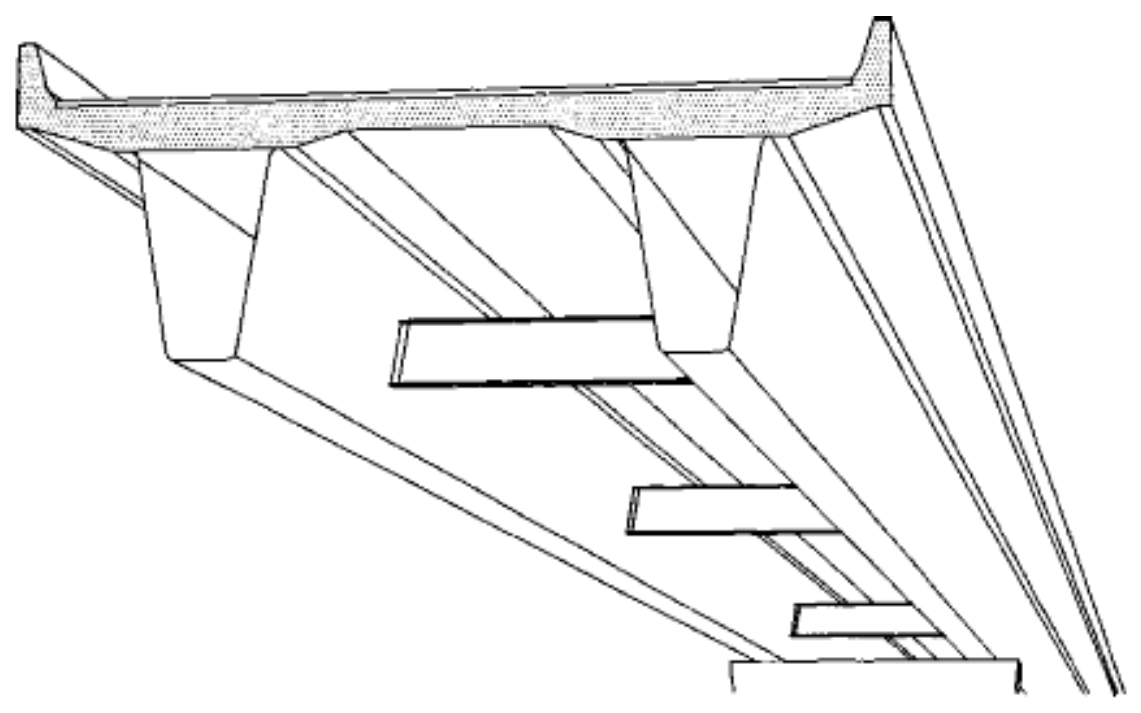

Figure 2.5: Nakamura's Proposed Bridge System (Nakamura, 2002)

Nakamura carried out bending tests to investigate the behavior of the proposed design. These tests confirmed the system behaved as a composite beam at span centers and behaved as a prestressed beam over the intermediate supports with the filled concrete restricting the buckling of the steel plates in compression. The researcher concluded the modified tub-girder system had sufficient bending strength and deformation capacity and deemed the design to be feasible and economical. A shortcoming of the design is the requirement of more steel than a typical plate girder section; however, the fabrication cost is more dominant than the material cost, suggesting the total construction cost could be lowered.

\subsubsection{Folded Plate Girders (Developed at the University of Nebraska)}

Researchers at the University of Nebraska have performed testing on cold-bent steel tub girders with a composite reinforced concrete deck. Figure 2.6 shows the system where an inverted tub-girder has flanges bent inward and a concrete deck poured on the wider center flange, opposed to the previous systems where the deck was cast on smaller exterior flanges. Glaser (2010) specifically investigated the constructability of the girder. During construction, a bridge is in its 
least stable condition due to not having the concrete to join the members together; it is important the bridge components exhibit both adequate strength and stability non-compositely during this critical stage (Glaser, 2010). The researcher performed a flexure test of the non-composite beam to simulate the loads present during construction. The system displayed stability and ductility through testing because there were no measurable permanent deformations in the girder at loads equivalent to those experienced during construction. Advantages of this system include a safer work area due to the wider top flange and easier access for maintenance and inspection by the bottom being open.

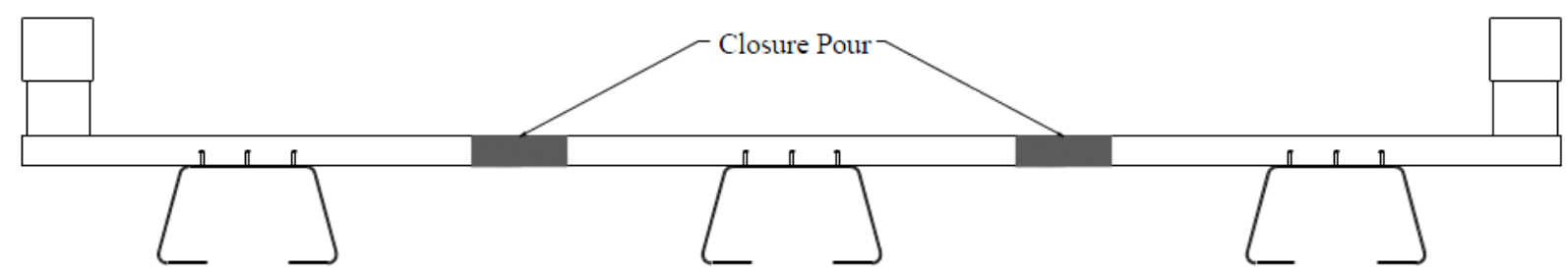

Figure 2.6: System Proposed at the University of Nebraska (Burner, 2010)

Another researcher at the University of Nebraska, Burner (2010), subjected the composite inverted tub girder to fatigue loading and investigated the rebar details in closure regions between adjacent slabs. Based on the fatigue testing, the inverted girder withstood the equivalent of 75 years of traffic without a significant loss in stiffness. The bends of the tub girder, which contain residual stresses from the cold-bending, did not experience any change in behavior through fatigue testing. The optimum rebar detail was found to be hooked bars because they do not pose the same concrete cover issues found with headed bars. Headed bars can be difficult to obtain due to their specialized fabrication where hooked bars do not require specialized fabrication details.

\subsubsection{Texas Department of Transportation Rapid Economical Bridge Replacement}

The Texas Department of Transportation (TxDOT) developed a highly construable, light, and efficient shallow trapezoidal steel box girder for the FM 3267 bridge on a six lane stretch of I-35 located 75 miles north of Austin, Texas (Chandar et al., 2010). The tub girder consisted of a 
five foot wide bottom flange welded to two three foot deep webs, as seen in Figure 2.7, with two rows of shear studs welded to the top flanges. The shear studs connected the trapezoidal box girder to the cast-in-place concrete deck. Due to the lightweight nature of box girders, each girder was directly supported by individual columns, removing the need for a bent cap and reducing construction time.

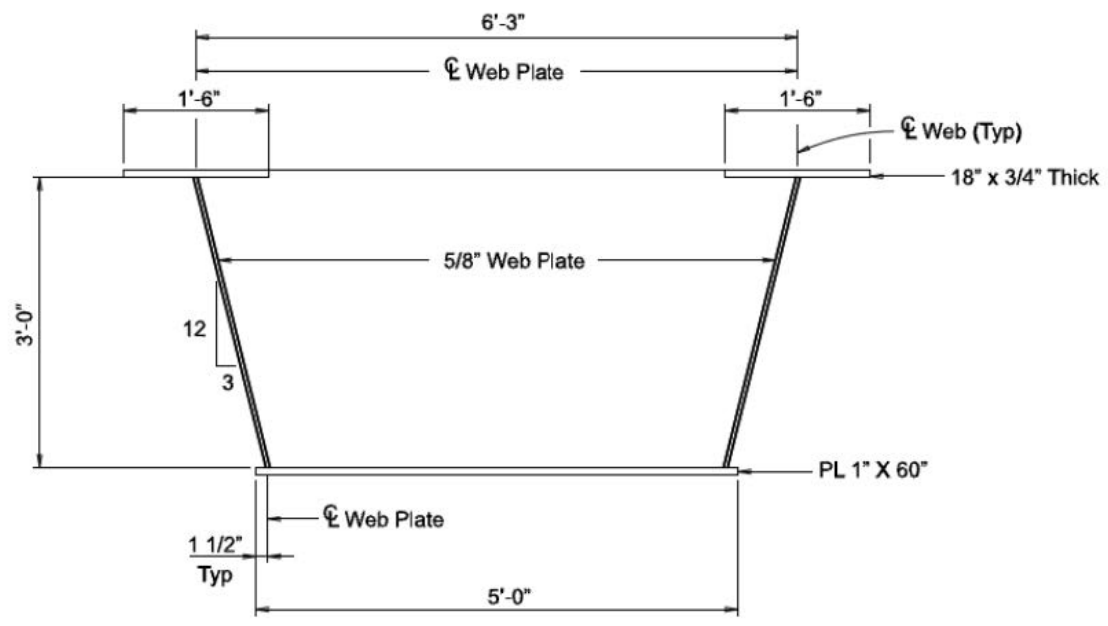

Figure 2.7: TxDOT Trapezoidal Box Girder for Rapid Bridge Replacement (Chandar et al., 2010)

The bridge consisted of six shallow box girders with a combined width of 78 feet with four spans of lengths of 45 feet, 100 feet, 100 feet, and 65 feet respectively. The box girder section was designed for a 100 foot section, and the 45 foot and 65 foot sections used the same larger section reducing design time. While $\mathrm{ABC}$ methods were implemented in design, conventionally fabricated steel tub girders, comprised of welded plate sections, were employed as opposed to girders formed using cold-bending.

\subsubsection{MDOT Prefabricated Composite Steel Box-Girder Systems for Rapid Bridge Construction}

The Michigan Department of Transportation (MDOT) was interested in a completely prefabricated composite steel box girder which could be shipped to the construction site where only placement and post-tensioning would be required to complete construction (Burgueño \& 
Pavlich, 2008). As seen in Figure 2.8, the system consists of a press-formed or cold-bent steel plate connected to a cast-in-place or precast deck by shear studs. The goal was to gain knowledge of this modular system by performing multiple finite element analyses to address the global system response of the system to applied loads, the localized behavior of joints, and the effect of reduced post tensioning on both the global system and the joints. Researchers found issues including fatigue deficiencies with cold-bent plates, efficiency of box sections, and difficulty with internal inspection of the girder. However, they addressed each concern and found the system to be a feasible option in the short span bridge market and a rapid construction alternative.

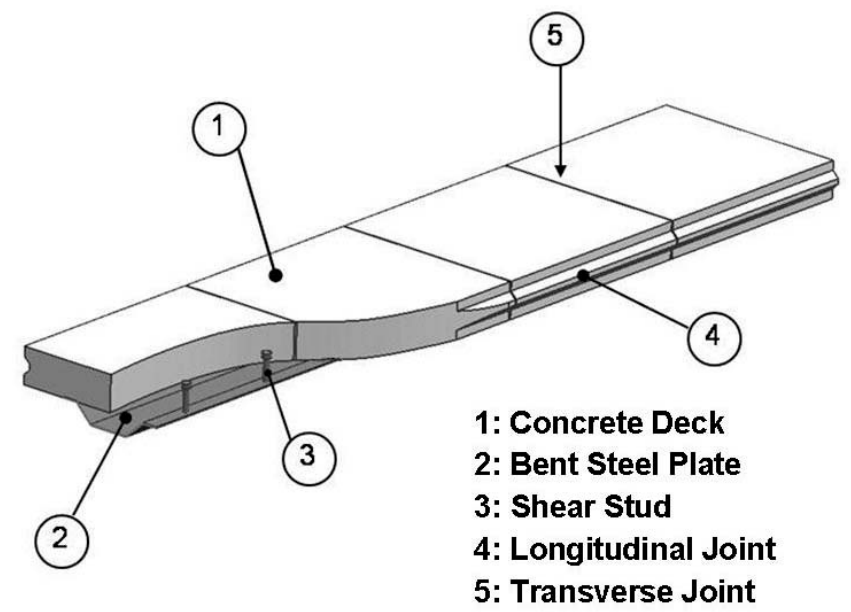

Figure 2.8: MDOT Proposed Bridge System (Burgueno \& Pavlich, 2008)

\subsubsection{Con-Struct Prefabricated Bridge System}

The Con-Struct Prefabricated Bridge System was established in 2004 as an answer to the growing demand for $\mathrm{ABC}$ products (Con-Struct Pamphlet). The system, as seen in Figure 2.9, is a prefabricated composite bridge consisting of a shallow steel tub girder and a concrete deck. The concrete deck is cast on the steel tub girder when the girder is cambered. Cambering the girder in this fashion increases the serviceability of the system. Designs of this system are valid up to 60 feet in length and are available in various classes for different desired service lives. The Con-Struct system has been implemented by states such as Minnesota, Missouri, and Michigan. 


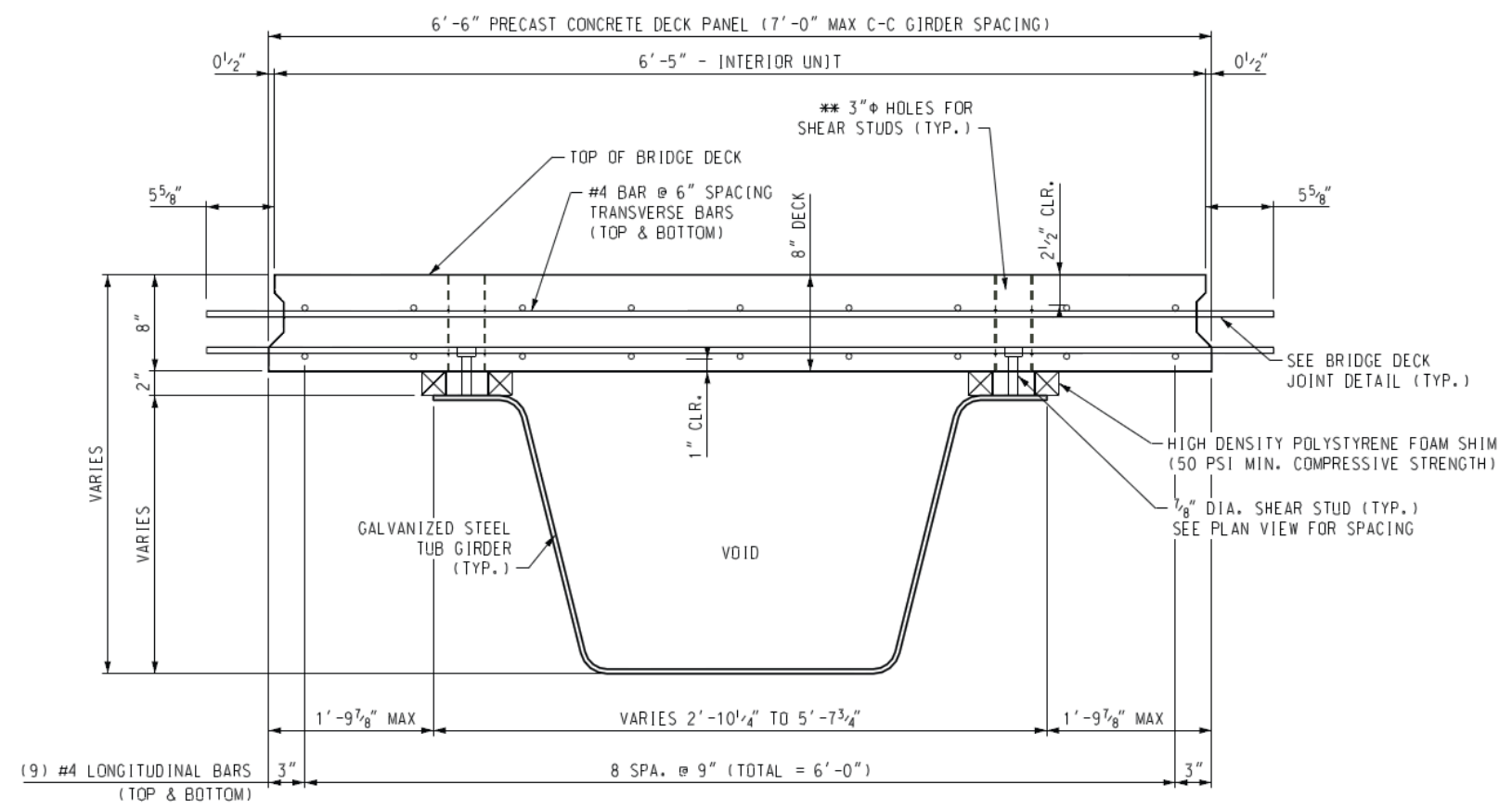

Figure 2.9: Typical Interior Con-Struct Cross Section

\subsection{Previous Research at WVU on Press-Brake-Formed Steel Tub Girders}

\subsubsection{Development and Feasibility Assessment of Shallow Press-Brake-Formed Steel Tub Girders} for Short-Span Bridge Applications (Michaelson 2014)

The SSSBA developed the notion of a shallow press-brake-formed tub girder consisting of cold-bending standard mill plate width and thickness. In the design, shear studs are welded on the upper flanges and a reinforced concrete deck is cast on top of the newly formed girder. This process takes place in a fabrication shop and the concrete cures creating a composite unit. This modular unit can be shipped to the construction site allowing for quicker construction.

To design the tub-girders, Michaelson (2014) first developed a spreadsheet to compute the section properties of any configuration of different bent plate sizes. In this study, three different standard plate thicknesses were considered: 7/16, 1/2, and 5/8 inch. Six different standard plate widths were evaluated: 60, 72, 84, 96, 108, and 120 inch. The bottom flange width and depth of web were varied to find the optimum design while keeping other variables, such as slope of the 
web, inside bend radii, and top flange widths, constant. The optimum design was assessed by comparing total girder depth to yield moment of the composite section. Figure 2.10 displays an example of the comparison of total girder depth to yield moment and shows the optimum depth of an 84 inch wide standard mill plate.

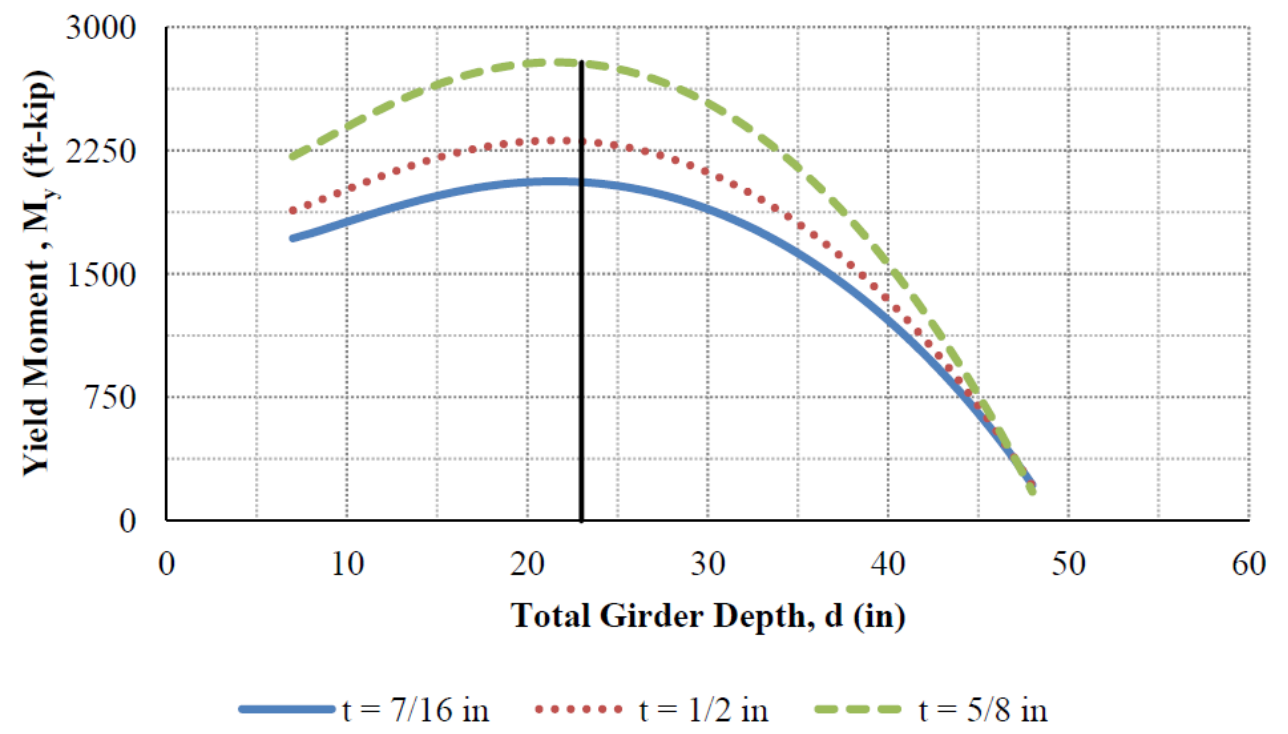

Figure 2.10: Design Comparison of 84" Wide Plate (Michaelson, 2014)

Physical flexural testing was performed on the composite and non-composite modular tub girders to confirm the performance and capacity of the units. Specimens were simply supported and flexural testing occurred in three-point bending. Two girders were tested non-compositely without the reinforced concrete deck or shear studs welded to the top flanges and two were tested with the reinforced concrete deck cast on top. Each of the four specimens tested was made from 84 inch wide x 7/16 inch thick x 280 inch long plate. This plate was chosen for testing because it created the largest tub-girder which could be tested to ultimate failure using a 330-kip servo hydraulic actuator. The deck thickness was shortened from eight inches to six inches to ensure failure could be reached. The composite section's failure was controlled by ductility where the concrete deck crushed under a load of approximately 300 kip and 3.1 inches of midspan deflection. The non-composite sections failed as the tub-girders began to exhibit significant lateral deflection and twist. 
Michaelson also performed two separate analyses to evaluate the behavior and capacity of the proposed system. Finite element analysis (FEA) was used and results were compared against experimental data to assess legitimacy and precision. A comparison of the FEA and experimental results can be seen in Figure 2.11. A strain-compatibility assessment evaluated the flexural capacity of the press-brake tub girder. An iterative approach was used to predict the ultimate capacity of the section in positive flexure. The approach proved adequate in determining the capacity of the composite section.

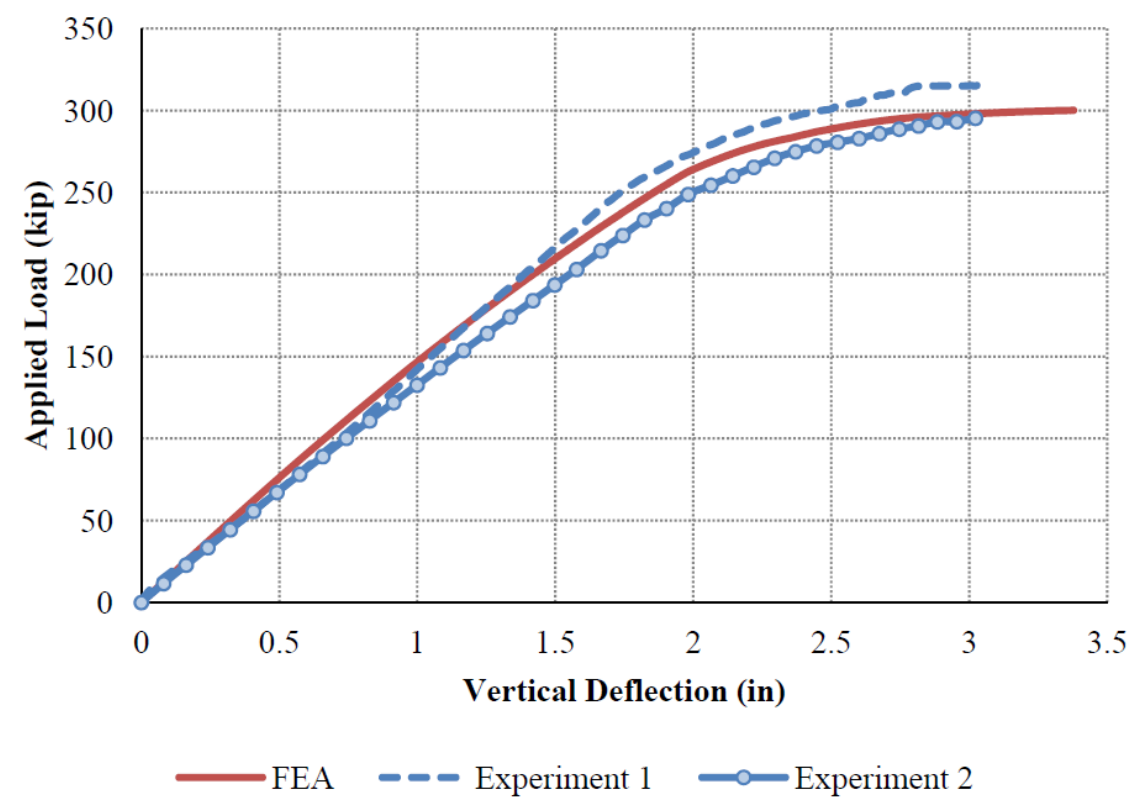

Figure 2.11: Comparison of Experimental and Analytical Results (Michaelson, 2014)

Behavioral studies were employed to assess the applicability of AASHTO Load and Resistance Factor Design (LRFD) specifications for the system. The nominal flexural capacity calculations from the specifications were slightly conservative for determining the capacity of the system. An assessment of non-composite stability behavior showed other means of construction were possible, such as a cast-in-place concrete deck. The loads present during construction were found to be substantial for an open press-brake-formed tub girder. The finishing machine and other torsional loads, such as eccentric concrete loads, proved the girder was susceptible to lateral torsional buckling under one third of the load applied to the composite section. However, stay-inplace metal formwork greatly improved the performance of the non-composite system. 
Michaelson addressed the feasibility and compared the proposed system to traditional options for short span bridges. A set of girders were proposed by eliminating plates which are not regularly manufactured. It was found that widths of 72, 96, and 120 inch are industry standard and most producers in the United States produce 1/2 inch thick plate steel. Four standardized systems were found to be economically competitive for different spans with live load distribution factors equal to 1.0. The author stated further research assessing live load distribution factors for tub girders may further increase economic competitiveness.

\subsubsection{Experimental Evaluation of Non-Composite Shallow Press-Brake-Formed Steel Tub Girders} (Kelly 2014)

In conjunction with Michaelson, Kelly (2014) assessed the feasibility of a cast-in-place concrete deck in contrast to shipping a cured modular composite unit. While pouring the concrete deck, the non-composite steel open section must support the construction load including the wet concrete. Two girders were non-compositely tested under three-point bending. Before testing began, an initial tilt was noticed in both girders. Figure 2.12 shows the inclination of the webs at points across the length of the girder where no inclination should exist. The galvanized specimen had a much higher initial twist than the weathering steel specimen due to fabrication errors prior to hot dip-galvanization.

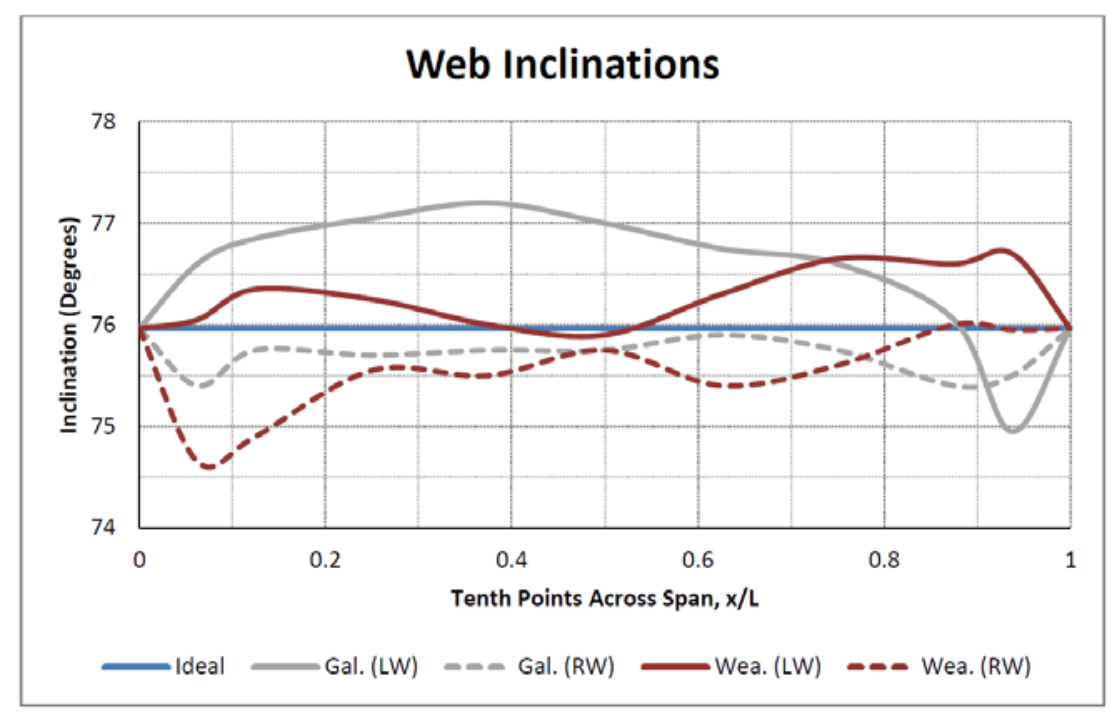

Figure 2.12: Web Inclinations (Kelly, 2014) 
The first-order lateral torsional buckling capacity of the tub girder was calculated to 10,590 in-kip corresponding to a point load at mid-span of 92.3 kip. The weathering steel specimen deflected linearly up to a loading of 94 kip, consistent with the calculated limit, when it suddenly failed in lateral torsional buckling, as seen in Figure 2.13. The testing of the galvanized steel specimen performed similarly until a critical loading of 33 kip, when it suddenly failed in lateral torsional buckling. The loss of capacity was attributed to the second-order effects relating to initial fabrication imperfections prior to galvanization.

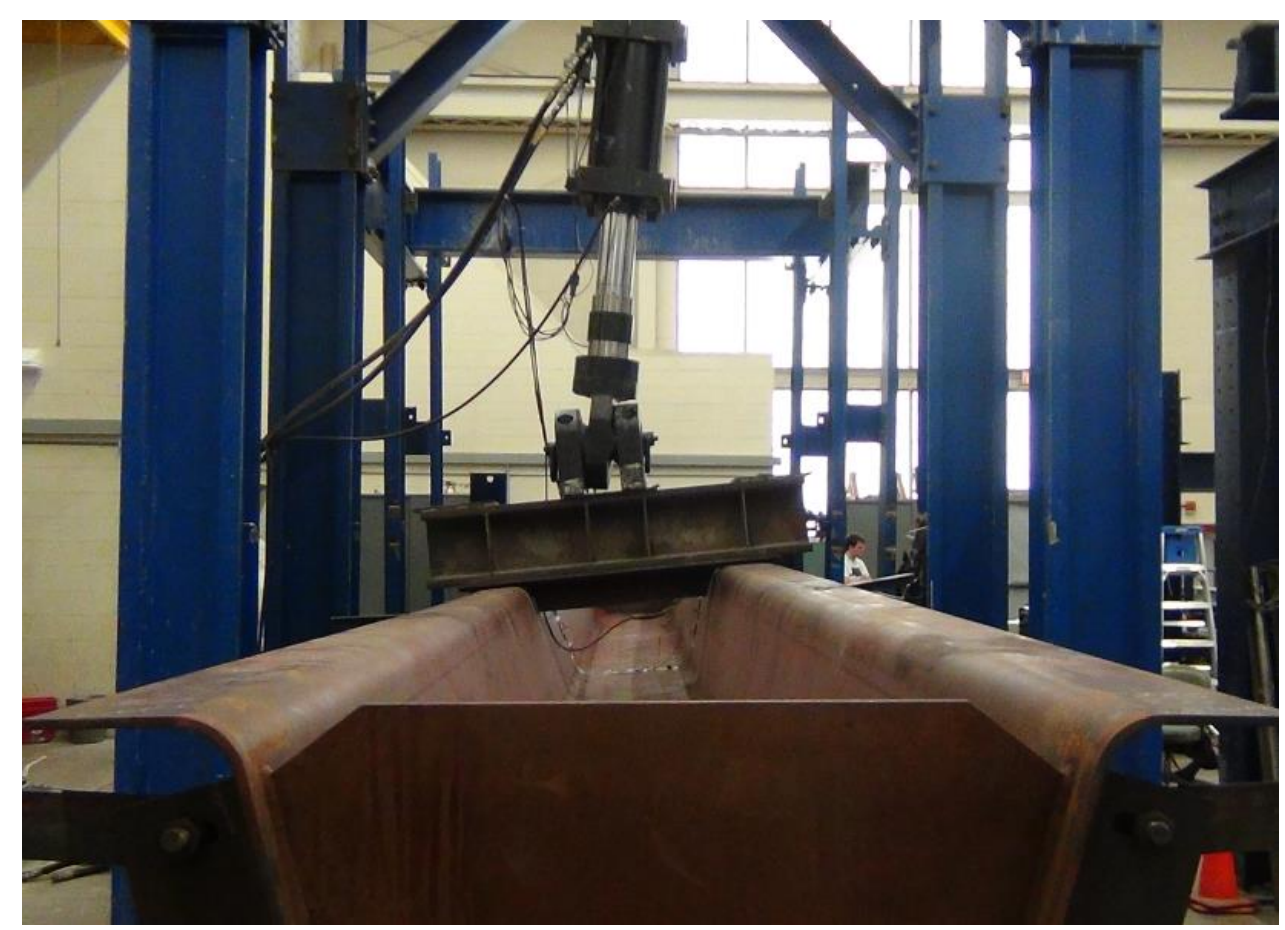

Figure 2.13: Lateral Torsional Buckling (Kelly, 2014)

2.4.3 Evaluation of Modular Press-Brake-Formed Tub Girders with UHPC Joints (Kozhokin, 2016)

Durable connections are needed to join modular prefabricated bridge elements and systems together. Ultra-high performance concrete (UHPC) is a cementitious material containing Portland cement, silica fume, quartz flour, fine silica sand, high-range water reducer, water, and steel fibers. Kozhokin (2016) tested the structural performance of modular press-brake-formed tub girders connected by UHPC. Two techniques can be used to create an exposed aggregate finish for the 
slab edge. The first technique involved applying a retarder to the shear key formwork and wire brushing the concrete. The other technique included gluing a 3/4 inch stone to the formwork to create voids in the concrete slab edge after formwork removal. After testing both techniques, the form retarder and wire brushing to remove concrete paste produced the better results and was used during construction of the full-scale model, as seen in Figure 2.14.

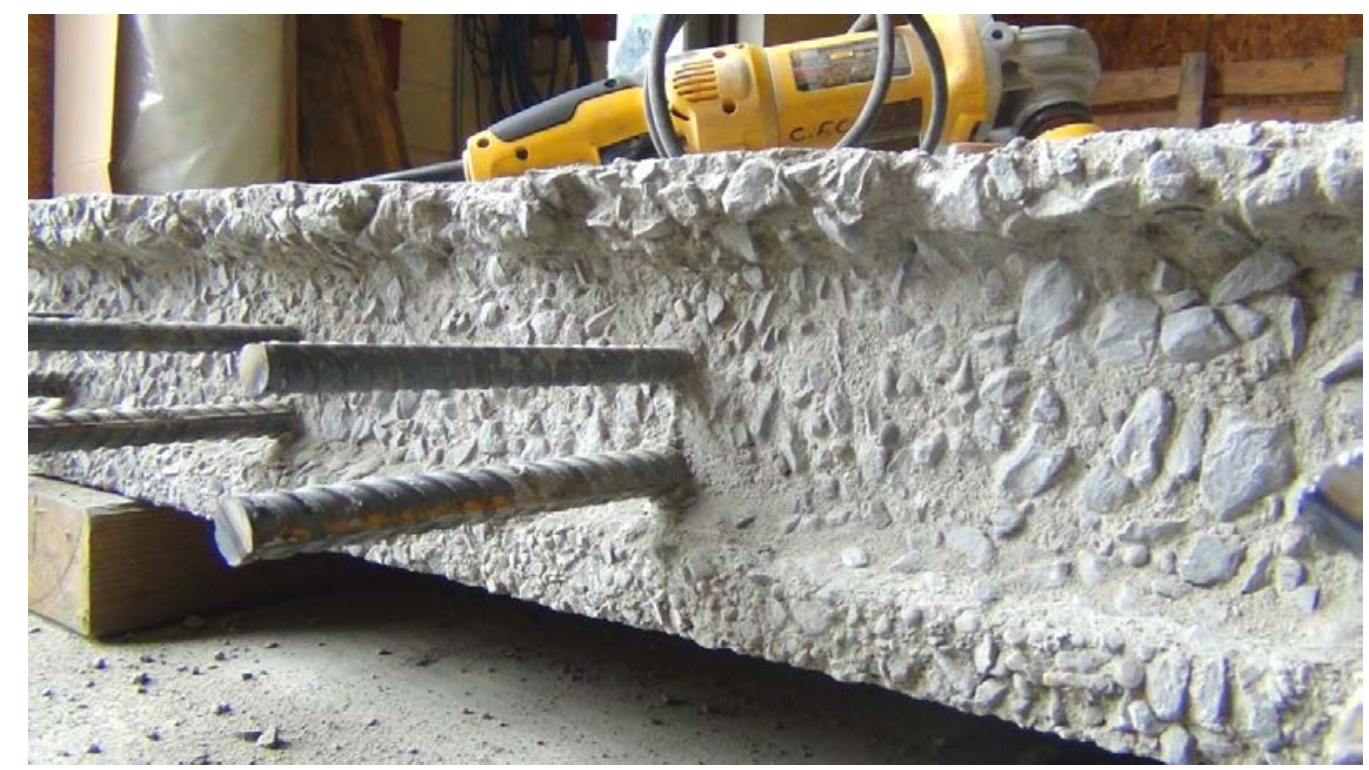

Figure 2.14: Concrete Surface after Wire-Brushing (Kozhokin, 2016)

The UHPC joint was poured between two modular press-brake-formed tub girders with a reinforced concrete deck cast on top. After the two modular units were combined with UHPC along the length of the specimens, a 67.43 kip cyclic load was applied to induce the Fatigue I moment over 2,737,500 cycles. The Fatigue I load combination reflects the load found to be representative of the maximum stress range of the truck population for infinite fatigue life design. The load was applied in the center of one of the press-brake formed tub girders through a 20 inch $\mathrm{x} 10$ inch $\mathrm{x} 1$ inch plate to replicate a truck tire contact area. At a predetermined amount of cycles, the fatigue loading halted and a static load was applied, inducing a Service II moment, to see if the twin tub girder unit began to act abnormally.

After 1,635,000 cycles, the concrete deck failed by punching shear directly under the load application. The actuator was moved to the center of the other girder and a 30 inch x 18 inch x 1/2 
inch plate was used under the actuator to help spread the load and to avoid the punching shear failure seen previously. Loading of the second girder continued through 2,800,000 cycles with only a single shear crack propagating across the UHPC joint from the failed deck region (Figure 2.15). Material testing of the concrete determined the compressive strength of the deck concrete was only 3,000 psi after 28 days, which contributed to the punching shear failure. The UHPC joint performed satisfactorily throughout subsequent testing transferring stresses from one girder to the other.

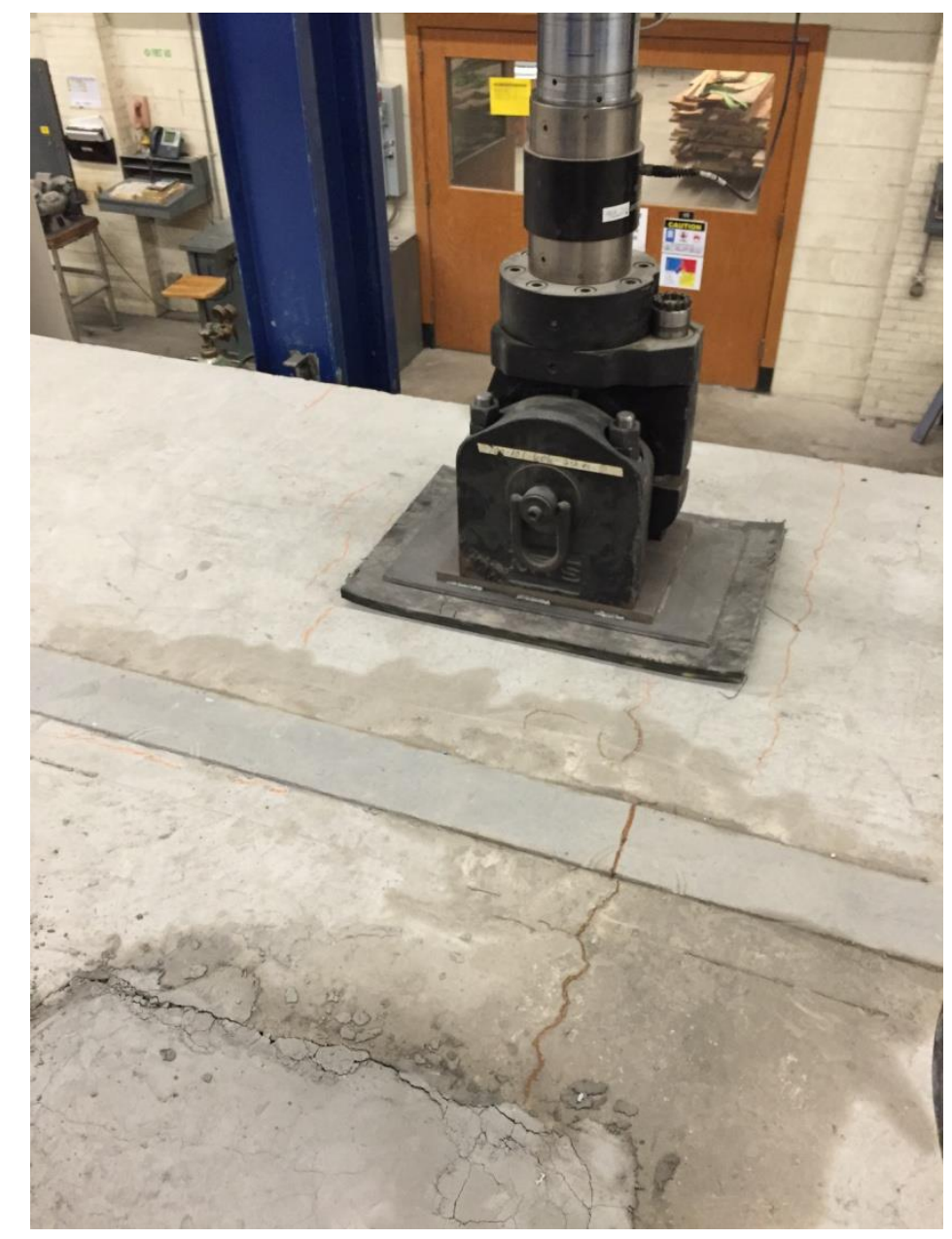

Figure 2.15: Shear Crack Propagated Across UHPC Joint (Kozhokin, 2016) 


\subsection{CurRent IMPLEMENTAtions OF PRESS-BrAKE-Formed STEEL Tub GiRders}

\subsubsection{Amish Sawmill Bridge in Buchanan County, Iowa}

County Engineer Brian Keierleber, P.E. managed construction of the first bridge designed, constructed, and opened to traffic utilizing press-brake-formed steel tub girders (Gibbs, 2017). Demolition of the old bridge began late in the summer of 2015 and the construction of the new bridge was complete in December of 2015. Four galvanized tub girders, made from 96 inch wide by $1 / 2$ inch thick plate were bent before being shipped to the site. Contractors chose to use a 31 foot 3 inch wide by 8 1/2 inch thick cast-in-place concrete deck. In addition to utilizing tub girders, the New Amish Sawmill Bridge used GRS-IBS consisting of GRS abutments with a galvanized sheet piling face. Researchers from West Virginia University and Marshall University traveled to Iowa to perform testing when construction was completed (Figure 2.16).

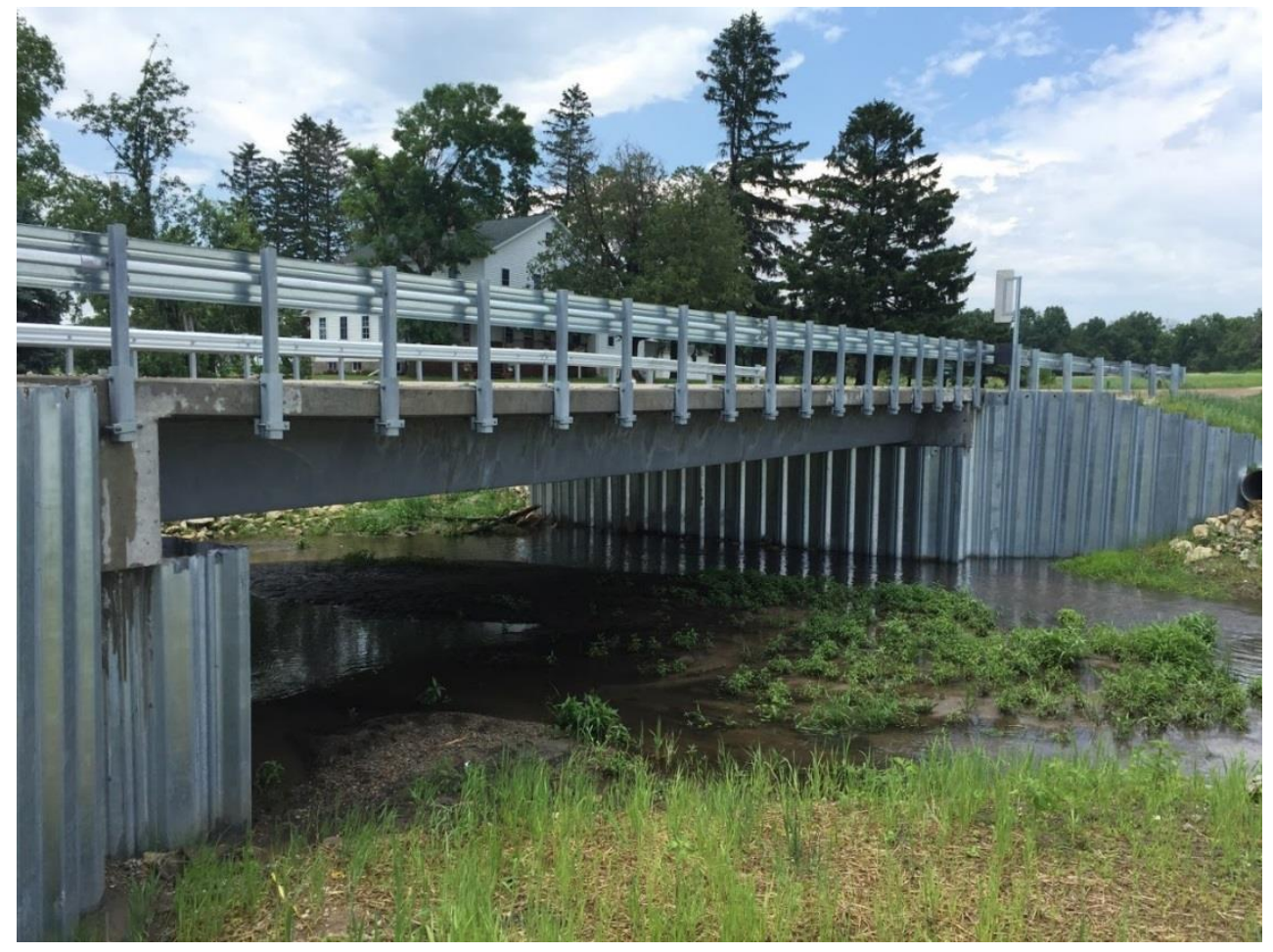

Figure 2.16: New Amish Sawmill Bridge (Gibbs, 2017) 
Experimental testing was performed on site by researchers while FEA was performed on a model of the bridge. The purpose of the testing was to investigate if AASHTO specifications could safely be applied to press-brake-formed tub girders. Comparing results from the live load field test to the finite element model analysis shows the live load distribution factors (LLDFs) were very close, but the actual bending stresses in the field test bottom flanges were much lower than the finite element model. This was attributed to differing boundary conditions. The Amish Sawmill Bridge design included integral abutments, but the finite element model utilized simply supported boundary conditions. Simply supported conditions were used in the model because there are not proper methods in current practices to replicate integral abutments. When comparing the LLDFs from the load test and the finite element model with AASHTO specifications, the AASHTO specifications were considerably higher (Figure 2.17). From this study, it was determined LLDFs calculated using specifications from AASHTO may be used for press-brake-formed tub girders with the understanding that the method is very conservative.

Truck Run \#2 Average LLDFs

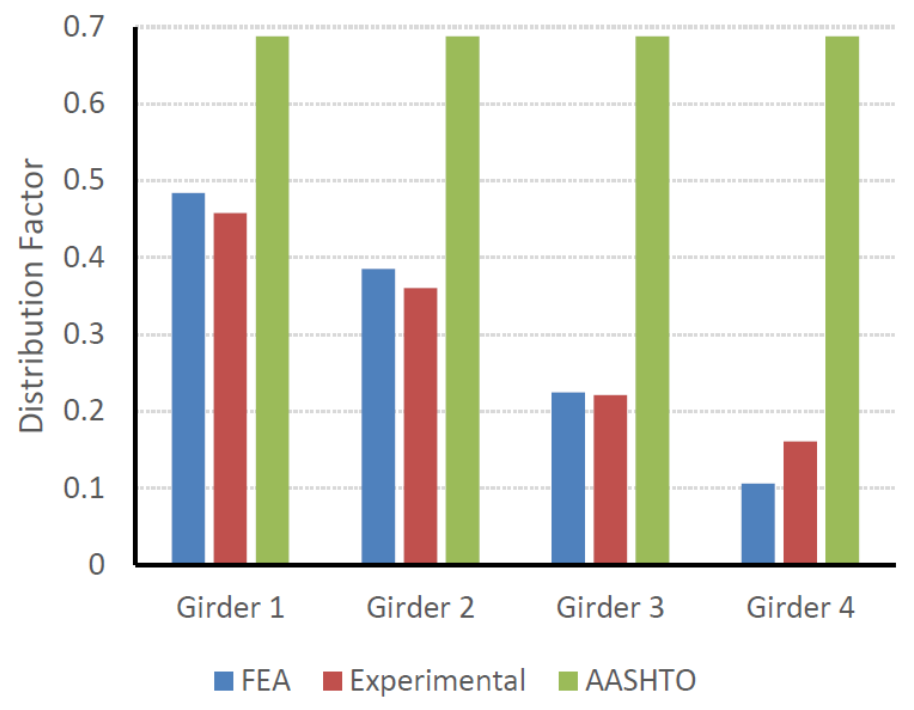

Figure 2.17: FEA v. Experimental v. AASHTO LLDFs (Gibbs, 2017) 


\subsubsection{Cannelville Road Bridge in Muskingum County, Ohio}

The new Cannelville Road Bridge, opened on May 27, 2017, was the first press-brakeformed tub girder in Ohio. The bridge consisted of a thin, lightweight Sandwich Plate System (SPS) bolted to the girders in a fabrication shop, so the modular unit could be rapidly assembled at the construction site. The bridge contained two modules, each consisting of two tub girders joined by the SPS deck and cross bracing between the tub girders. The entire system was hotdipped galvanized, extending the life of the bridge up to 100 years. Both modules were lifted and placed on their abutments in only 22 minutes (Figure 2.18). The entire bridge construction, including removal of the old bridge and abutments, driving of new foundations, pouring of new abutments, and erection of the superstructure, was accomplished in 26 days.

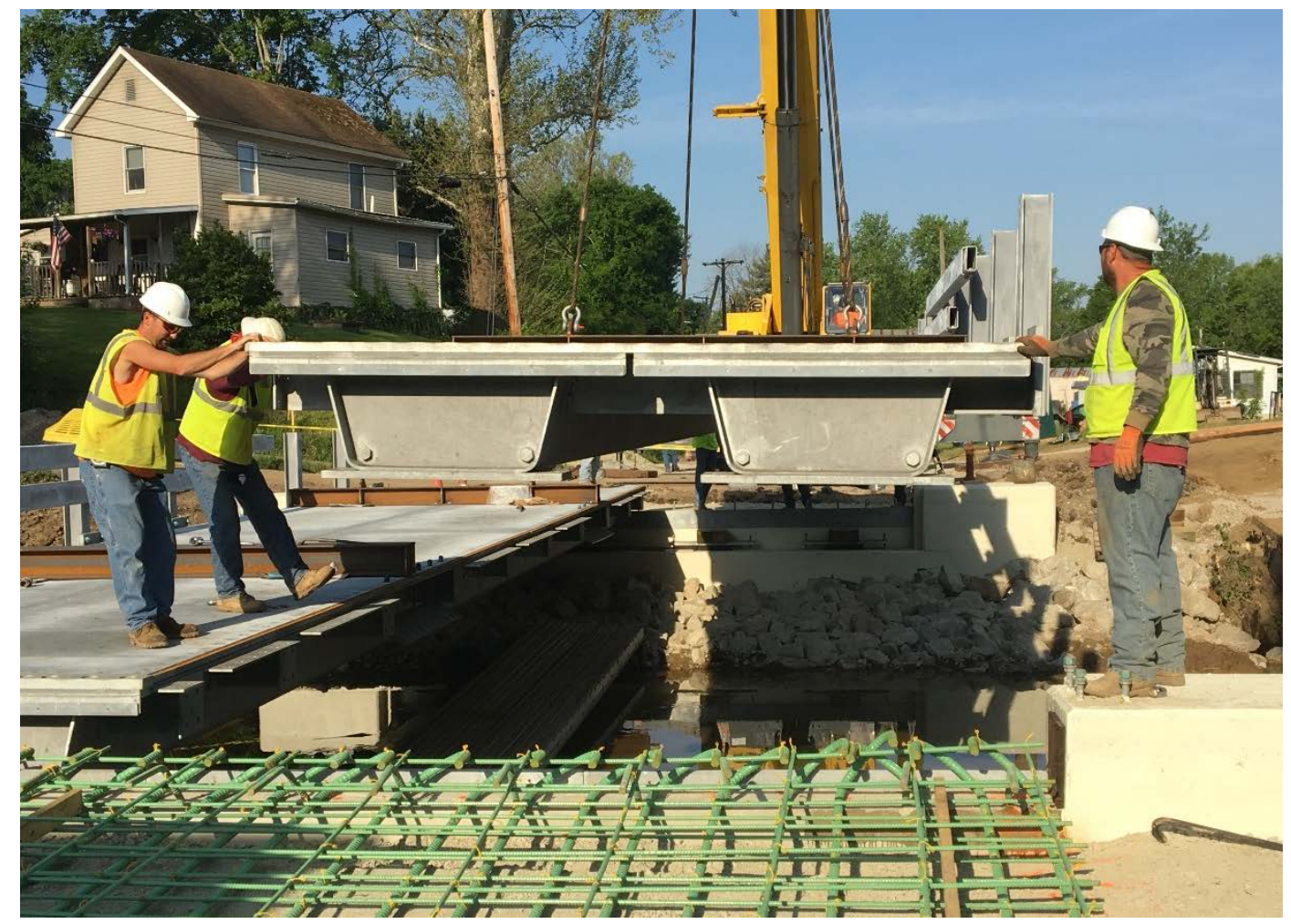

Figure 2.18: Modular SPS Deck/Tub Girder System Being Lowered in Place 


\subsection{Corrosion Protection Systems}

\subsubsection{Corrosion Process}

When deciding which material to be used in the construction of steel bridge girders, the designer must consider corrosion protection systems. Corrosion of steel is an electrochemical process which occurs in stages. Parts of the steel surface act as anodes and others act as cathodes (Figure 2.19.) Ferrous ions enter solution on anodic areas where free electrons are released. These electrons move to cathodic areas on the surface of steel where they combine with oxygen ions to form hydroxyl ions. These hydroxyl ions react with ferrous ions forming rust at the anodic areas of the surface. Steel corrosion can only occur when both oxygen and water are present simultaneously. With time, new anodic areas form on a steel surface creating areas for further corrosion (Corus, 2004).

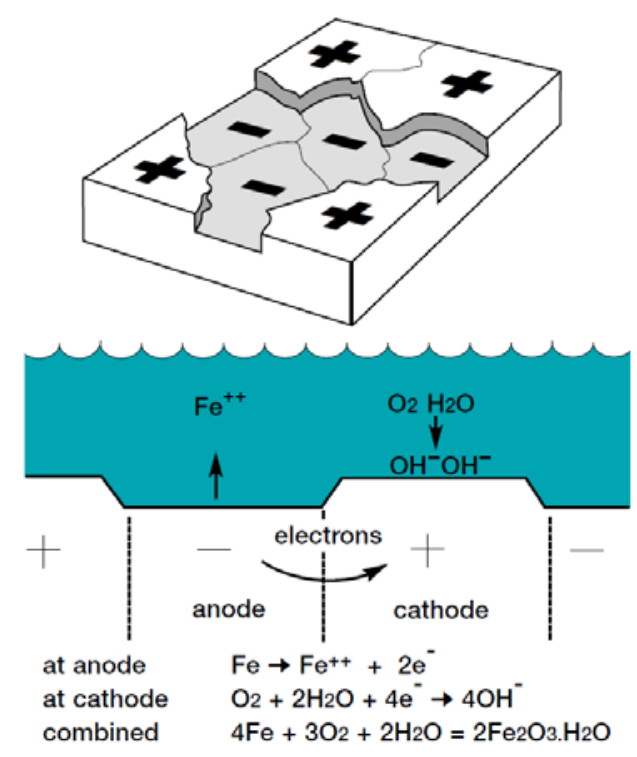

Figure 2.19: Schematic Representation of the Corrosion Process (Corus, 2004) 
The principle factors determining the rate of corrosion of steel in air are time of wetness, atmospheric pollution, and localized corrosion, such as bimetallic and crevice corrosion. Time of wetness is the amount of time steel is exposed to water. Steel would not need a protective system in a dry environment, such as the interior of a heated building, due to lack of water, or in a completely submerged environment due to lack of oxygen. Atmospheric pollution refers to contaminants, such as sulfates, chlorides, and dust. Sulfates originate from the combustion of fossil fuels, such as sulfur bearing oils and coal. The sulfur dioxide gas emitted from the combustion of fossil fuels reacts with water in the atmosphere to create sulfurous and sulfuric acids. Sulfur dioxide typically originates in industrial environments. Chlorides are typically found in marine environments because the highest concentrations of chlorides are found in coastal regions. Sulfates and chlorides increase corrosion rates of steel by producing soluble salts, which are themselves corrosive, concentrated in pits on the steel surface. Bimetallic corrosion occurs when two different metals are joined together in an electrolyte causing an electrical current to pass between them and corrosion to occur on the anodic metal. Some metals, such as nickel and copper, cause steel to corrode whereas other metals, such as zinc, preferentially corrode when joined with steel. The further apart the joined metals are in the galvanic series, the greater the tendency of bimetallic corrosion as seen in Figure 2.20 (Ghavamian et al., 2015). 


\section{Corrosion Susceptibility of metals}

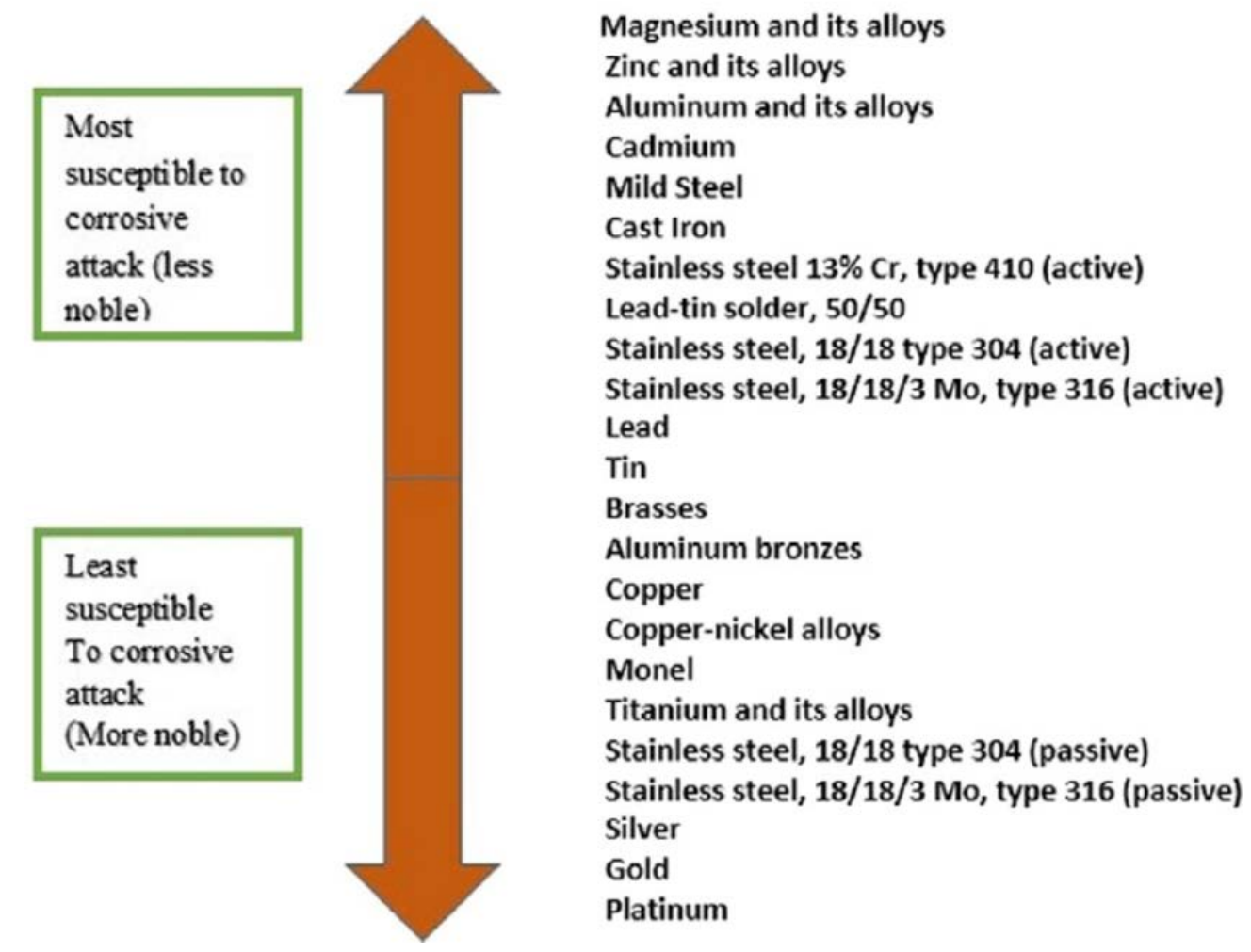

Figure 2.20: Galvanic Series (Ghavamian et al., 2015)

Design detailing, welding, and surface debris can cause crevices in steel surfaces. Oxygen in the crevice is used by the corrosion process and cannot be replaced. The entrance to the crevice becomes cathodic because the cathode reaction demands oxygen. The tip of the crevice becomes the anode in the reaction causing high corrosion at that localized point. 


\subsubsection{Painting Systems}

Protective paint systems conventionally consist of primer, undercoat(s), and finish coats (Figure 2.21). However, two coat systems combining undercoats and finishing coats are now available.

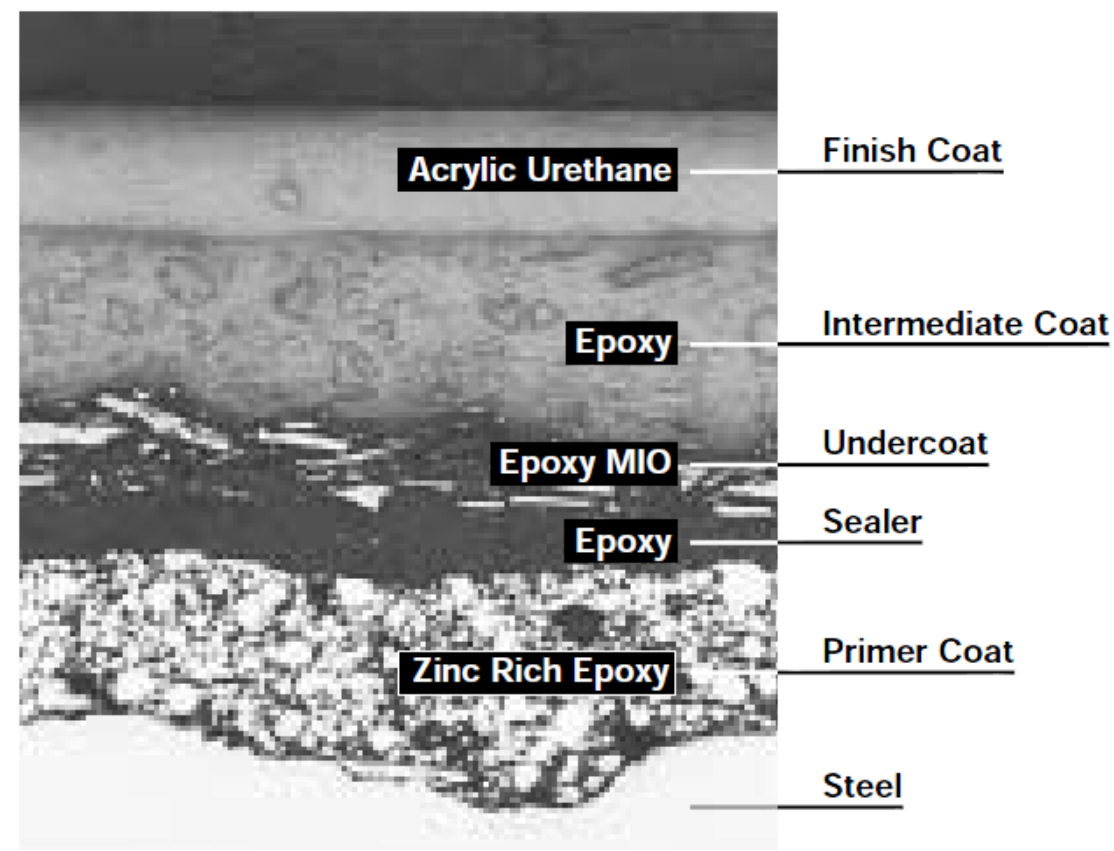

Figure 2.21: Conventional Protective Paint System (NPL, 2000)

Primers for steel surfaces are usually required to provide some corrosion inhibition. These primers are applied directly on the cleaned steel surface, wetting the surface and providing good adhesion for subsequent applied coats. There are two basic types of primer, the first being pigmented with metallic elements anodic to steel. An opening in this coating exposes the steel substrate causing the anodic metallic element to sacrificially oxidize protecting the steel. The other type of primer is typically an epoxy, which relies on its high adhesion and chemical resistance properties. Adhesion of this primer is highly dependent on a thoroughly clean surface to prevent under rusting at mechanical breaks.

Undercoats, or intermediate coats, are applied to build thickness of the paint system. Longer system life is generally dependent on the thickness of the system, so several coats may need to be applied. Highly pigmented undercoats decrease permeability of the paint system to 
oxygen and water. Laminar pigments, such as iron oxide, reduce or delay moisture penetration in humid environments and improve the tensile strength of the paint.

The finish coat provides the surface resistance and appearance of the system. The finish must provide the first line of defense against all environmental conditions, such as condensation as on the undersides of bridges, highly polluted atmospheres in chemical plants, impact and abrasion at floor or road levels, and bacteria and fungi in food factories and farms.

Paints are composed of three main components: pigment, binder, and solvent. Pigments are finely ground inorganic or organic powders dispersed in the binder, which is typically oil or resin. The solvent, typically water, dissolves the binder and when the solvent evaporates, a film layer remains on the surface as a protective coating. Paint systems consist of multiple layers of different paints serving different purposes.

The current standard for bridge coating is a three-coat system consisting of an inorganic zinc-rich primer, an epoxy midcoat, and a urethane topcoat (IOZ/E/U). Thousands of bridges constructed since the mid-1960s are coated with a zinc-rich primer paint as part of a paint system and are in excellent condition (Kline, 2009). Many structures, such as the Golden Gate Bridge in San Francisco, California, the Windgap Bridge near Pittsburgh, PA, and the Martin Luther King Bridge in Richmond, Virginia, consist of a zinc-rich primer, epoxy midcoat, and a urethane topcoat. The costs of this painting system, in 2009 dollars, is approximately $\$ 5.50$ for the initial blast cleaning, surface preparation, and prime coating in the shop and application of the second and third layers at the construction site and two touch-ups over the bridge life.

As bridge coating technology continued to evolve in the 1990s, advancements in binder technology allowed a reduction in the number of coating layers from three coats to two coats with the use of high-build, two-coat polyaspartic urethane (PAS) coating systems (Olson et al., 2017). PAS coating systems reduce the overall cost of painting with corrosion protection similar to the conventional three-coat systems. PAS systems utilize a similar zinc-rich primer as three-coat systems, but the epoxy and polyurethane layers are replaced by a high-build PAS topcoat. The difference between the two systems can be seen in Figure 2.22. 

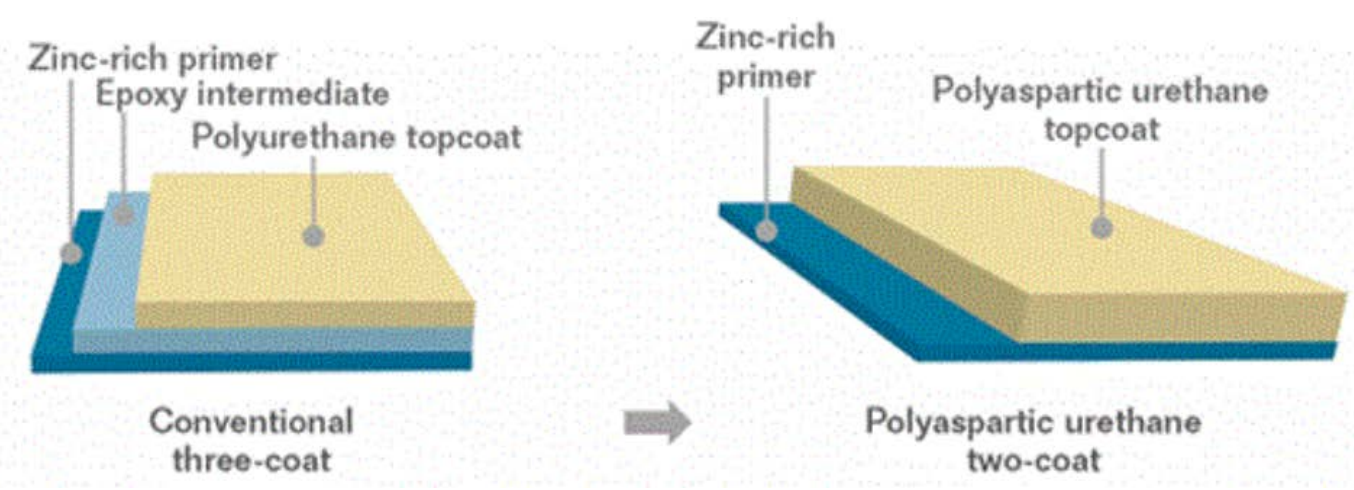

Figure 2.22: Comparison between 2-Coat and 3-Coat Systems (Olsen et al., 2017)

\subsubsection{Weathering Steel}

Weathering steels have a carbon content of less than $0.2 \%$ and have alloying elements (Copper, Cromium, Nickel, Phosphorus, Silicon, and Manganese) consisting of 3-5\%. The chemical composition of steel alloys is specifically formulated to rapidly form a layer of rust that provides a protective coating (AZO Materials, 2016). Copper and nickel act as the main alloys contributing to corrosion resistance by bonding the protective oxide layer to the underlying steel. The steel oxidizes because the system rusts slowly and the accumulated rust layer creates the coating to slow future corrosion. Bridges built with weathering steel can last up to 120 years with little maintenance because of this slow corrosion rate. Repeated wet/drying cycles are essential to create the optimum dense and adherent rust layer. Unwanted corrosion can occur in poorly detailed areas with crevices. The desired patina cannot form in crevices where water can collect.

The desired oxidation process occurs over several years before steady-state stabilization of the surface occurs with a tightly bonded coating. Phosphorus and sulfur contribute to formation of the patina layer by creating low-solubility phosphates and sulfates developed between underlying steel and the protective oxidized layer. Phosphorous specimens form a protective passive film over the steel, preventing the ingress of moisture supporting formation of a dense patina layer. Phosphorus can have a detrimental effect on the mechanical strength of the steel by effecting the alloy grain structure, so low level boron or carbon are added to the steel restoring required grain boundaries. Large amounts of non-metal oxides can result in acidification of the aqueous layer, which hinders patina formation. 
Chlorides are typically the largest concern in the United States as contamination may result from runoff of deicing salts applied to roadways or proximity of the structure to marine environments having high atmospheric chloride levels (Barth \& McConnell, 2010). The most desirable situation for weathering steel is where the steel is perpetually dry, so no corrosion will occur, but this is unrealistic. The best approach to long-term maintenance of weathering steel structures is to minimize its exposure to moisture. Proper design details are highly encouraged, such as the use of a continuous reinforced concrete deck to prevent water from reaching the girders, the removal of joints wherever possible, and the use of integral or semi-integral abutments. Periodical inspection and maintenance for cracks, open joints, and debris in the drainage system can drastically improve the structures life and reduce future corrosion.

\subsubsection{Hot-Dip Galvanization}

Hot-Dip Galvanizing is a process involving dipping steel into a container of molten zinc to form a corrosion protection layer surrounding the underlying steel. The process consists of three basic steps: surface preparation, galvanization, and inspection. Zinc will not react with a dirty surface, which leads to many cases of premature failure. To avoid this, three surface preparation steps are needed. The first step of the surface preparation process is to submerge the steel member in a hot alkali solution, mild acidic bath, or biological cleaning bath to remove organic contaminants. The second step is removal of mill scale and iron oxides from the steel surface by submerging the specimen in a heated sulfuric acid or ambient hydrochloric bath. Abrasive cleaning using blasted air with sand, metallic shot, or grit onto the steel can be done in addition to or without the previous step. The final surface preparation step is to remove any remaining rust and to deposit a layer of zinc using a zinc ammonium chloride solution. After the surface preparation, displayed in Figure 2.20, the material is completely immersed in a molten bath of $98 \%$ minimum pure zinc kept between $815^{\circ}-850^{\circ}$ Fahrenheit. The zinc reacts with iron in the steel to form metallurgically bonded zinc-iron intermetallic alloy layers. A layer of impact resistant pure zinc typically tops the intermediate alloy layers. The specimen being galvanized is slowly removed from the zinc bath while carefully draining or vibrating the excess zinc. After completion of galvanization, it is required to inspect the specimen for defects. 


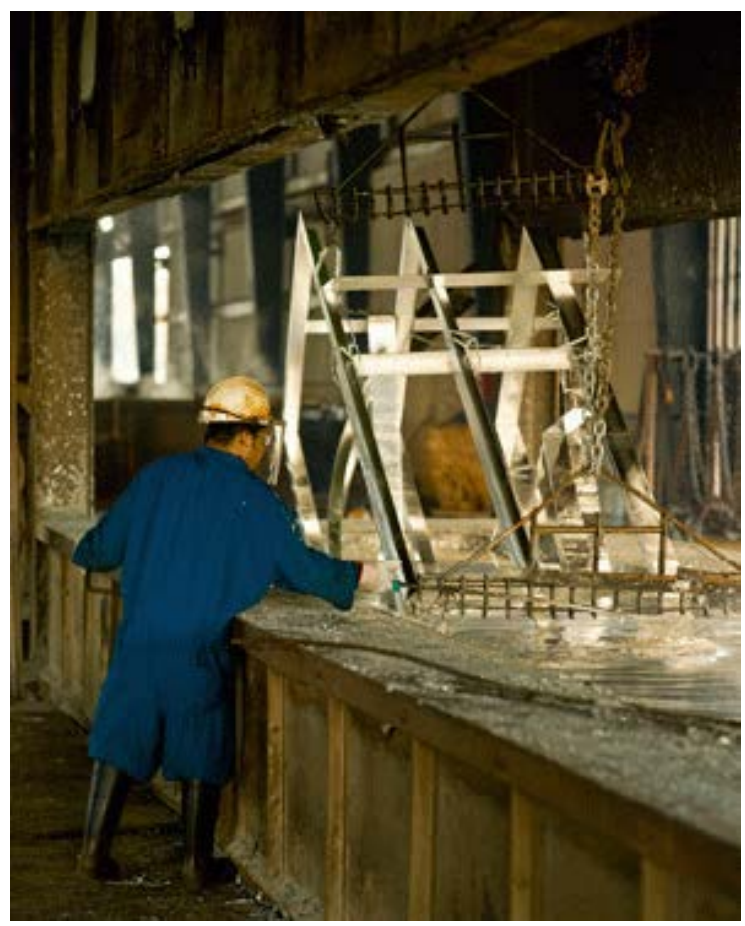

Figure 2.23: Dipping of Steel in Molten Zinc (American Galvanizers Association, 2018)

The coating developed during the galvanization process is metallurgically bonded to the steel. The zinc reacts with the iron in the steel to form a series of zinc-iron alloy layers during the reaction in the molten bath. Figure 2.23 shows a cross-section of the galvanized steel coating showing the typical layers of steel, alloys, and the top zinc layer. The hardness of each layer is expressed as a Diamond Pyramid Number (DPN) in Figure 2.23. The hardness of the Zeta, Delta, and Gamma layers are harder than the underlying steel providing abrasive resistance. The Eta layer, being more ductile, provides protection from impacts. 


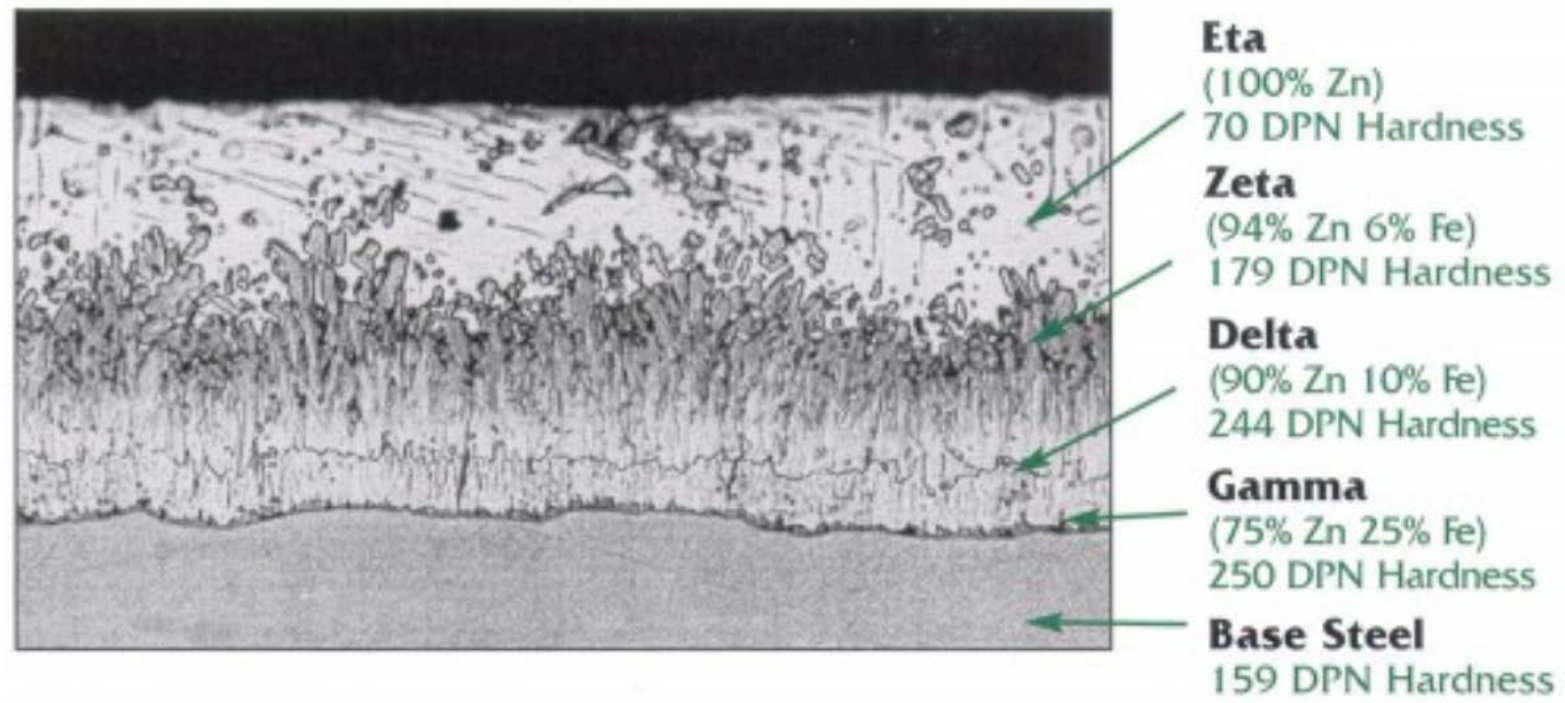

Figure 2.24: Cross Section of Galvanized Steel Coating (American Galvanizers Association, 2018) 


\section{CHAPTER 3: TUB GIRDER DESIGN EXAMPLE}

\subsection{INTRODUCTION}

The goal of utilizing tub girders is to develop a set of standardized designs that increases the efficiency of short span steel bridge design. Michaelson (2014) optimized the design used in this chapter. Efforts were made by Michaelson to include technical feedback from all aspects of steel construction, including, but not limited to, accounting for plate availability, upper bounds of girder length, and erection issues.

The girder was designed according to the 2014 AASHTO LRFD Bridge Design Specifications. It should be noted that in this design suite, once the girder was optimized for readily available plate sizes, a design review was conducted by evaluating limit state checks by reducing the overall plate width by two inches. This was performed to aid in potential fabrication practices where the plate is cut to be perfectly square. AASHTO LRFD specifications are referred to consistently throughout this chapter when discussing tables, articles, and equations.

\subsection{BRIDGE LAYOUT}

As shown in Figure 3.1, the bridge being evaluated is designed for a clear roadway width of 28 foot 4 inch including two 12 foot travel lanes and two 26 inch shoulders. The bridge has two Jersey-style barriers that are 19 inches wide. To accommodate the lanes and shoulders, the bridge in this design evaluation consists of four girders spaced at eight feet with 3 foot 9 inch overhangs. An 8.5 inch thick concrete deck is employed, which includes a 1/2 inch sacrificial wearing surface (i.e. an integral wearing surface (IWS)), and a 2 inch haunch measured from the top of the top flanges to the bottom of the deck. In addition, the bridge is designed for a simple span of 60 feet with no skew or super elevation in the girder layout. 


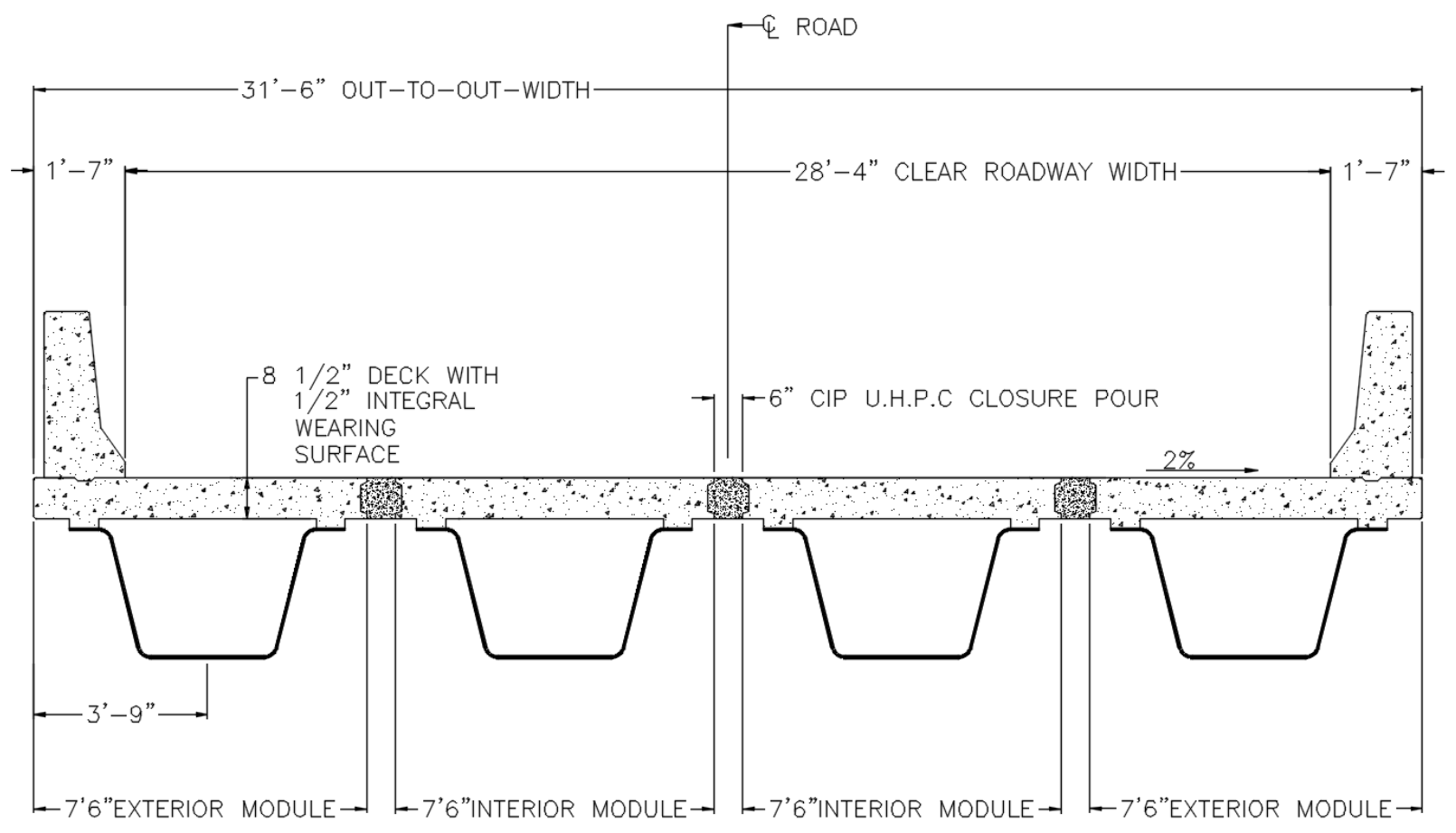

Figure 3.1: Typical Bridge Cross Section

\subsection{GIRDER GEOMETRY}

AASHTO Section 6.11-BOX-SECTION FLEUXRAL MEMBERS refers heavily back to ASSHTO Section 6.10-I-SECTION FLEXURAL MEMBERS; therefore, many articles and equations in this chapter are from Section 6.10 by reference of the corresponding Article in Section 6.11. As stated in AASHTO Article 6.10.1.1.1, the elastic stress at any location on the composite section due to the applied loads shall be equal to the sum of the stresses caused by the loads applied separately to the non-composite steel section, the short-term composite section, and the long-term composite section. For calculating flexural stresses, the concrete deck is transformed to an equivalent area of steel using the modular ratio $n$, where $n=$ eight for this bridge. For loads applied to the short-term composite section, the concrete is transformed by dividing the concrete's effective flange width by $n$. For loads applied to the long-term composite section, the concrete is transformed by dividing the concrete's effective flange width by $3 n$. 
AASHTO Article 4.6.2.6.1 states the effective flange width of a concrete deck shall be taken as the tributary width to compute the effective flange width. Barrier rails are often not structurally continuous, so the added deck width allowed by AASHTO Equation 4.6.2.6.1-1 is not included. Therefore, for the bridge layout in this evaluation the effective flange width for the girders is 96 inches. Tables 3.1 through 3.3 are used to calculate the section properties used in the limit state evaluations later in this chapter. The locations of each parts centroid and moments of inertia are specifically used in the determination of the composite flexural and shear capacities of the tub girders.

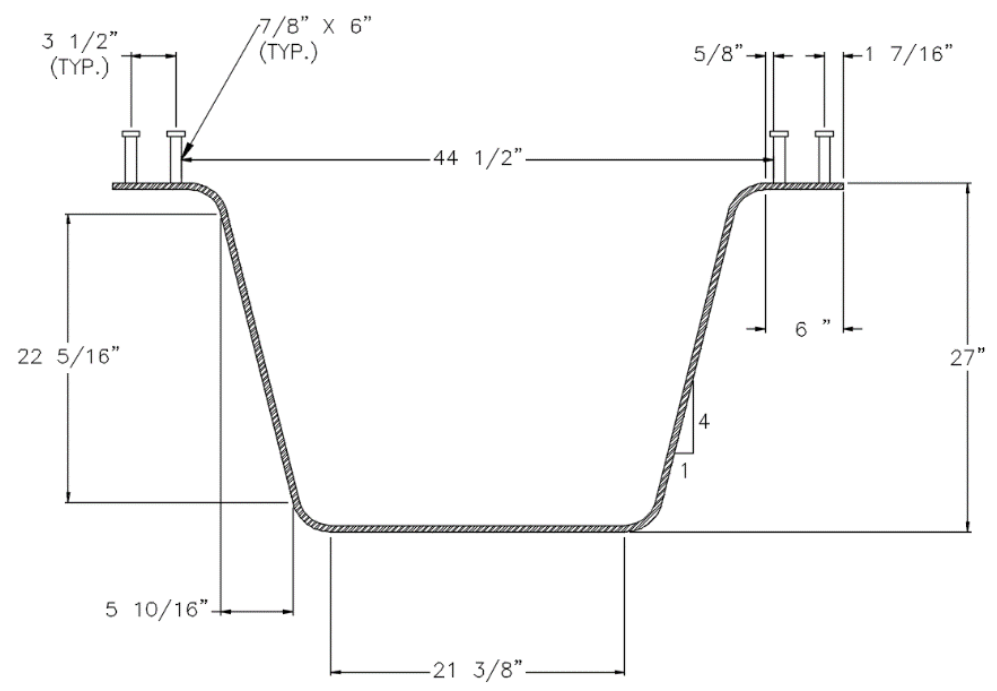

Figure 3.2: Girder Cross-Section

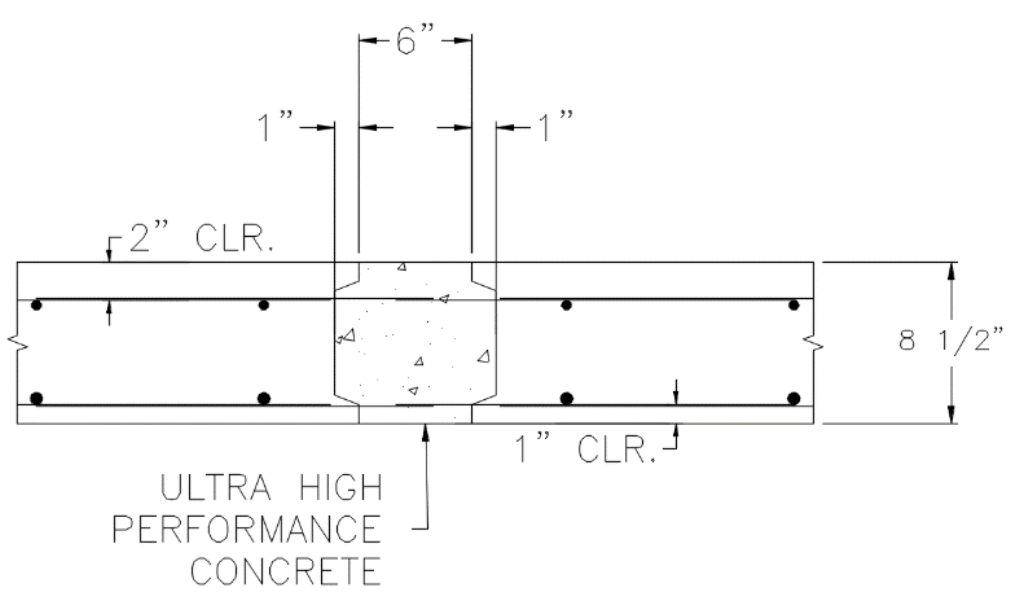

Figure 3.3: Joint Detail 


\section{Table 3.1: Non-Composite Section Properties}

\begin{tabular}{ccccccc}
\multicolumn{7}{c}{ Noncomposite Section } \\
Part & $\mathbf{A}\left(\mathbf{i n}^{2}\right)$ & $\mathbf{y}(\mathbf{i n})$ & $\mathbf{A y}\left(\mathbf{i n}^{3}\right)$ & $\mathbf{I}_{\mathbf{X}-\mathrm{C}}\left(\mathbf{i n}^{4}\right)$ & $\mathbf{d}_{\mathbf{Y}}(\mathbf{i n})$ & $\mathbf{I}_{\mathbf{X} \text {-X }}\left(\mathbf{i n}^{4}\right)$ \\
\hline $\mathrm{BF}$ & 10.7 & 0.25 & 2.7 & 0.2 & 11.9 & 1520.9 \\
$\mathrm{LR}_{1}$ & 1.8 & 1.0 & 1.8 & 0.8 & 11.2 & 229.3 \\
$\mathrm{LR}_{2}$ & 1.8 & 1.0 & 1.8 & 0.8 & 11.2 & 229.3 \\
$\mathrm{~W}_{1}$ & 11.5 & 13.5 & 155.4 & 478.5 & -1.3 & 498.6 \\
$\mathrm{~W}_{2}$ & 11.5 & 13.5 & 155.4 & 478.5 & -1.3 & 498.6 \\
$\mathrm{TR}_{1}$ & 1.8 & 26.0 & 47.4 & 0.8 & -13.8 & 349.9 \\
$\mathrm{TR}_{2}$ & 1.8 & 26.0 & 47.4 & 0.8 & -13.8 & 349.9 \\
$\mathrm{TF}_{1}$ & 3.0 & 26.8 & 80.3 & 0.1 & -14.6 & 637.0 \\
$\mathrm{TF}_{2}$ & 3 & 26.8 & 80.3 & 0.1 & -14.6 & 637.0 \\
\hline$\Sigma=$ & 47 & & 572.4 & & & 4950.5
\end{tabular}

\section{Table 3.2: Short Term Composite Section Properties}

\begin{tabular}{ccccccc}
\multicolumn{7}{c}{ Short Term Composite Section } \\
Part & $\mathbf{A ~ ( \mathbf { i n } ^ { 2 } )}$ & $\mathbf{y}(\mathbf{i n})$ & $\mathbf{A y}\left(\mathbf{i n}^{3}\right)$ & $\mathbf{I}_{\mathbf{X}-\mathrm{C}}\left(\mathbf{i n}^{4}\right)$ & $\mathbf{d}_{\mathbf{Y}}(\mathbf{i n})$ & $\mathbf{I}_{\mathbf{X}-\mathbf{X}}\left(\mathbf{i n}^{4}\right)$ \\
\hline Girder & 47 & 12.2 & 572.4 & 4950.5 & 14.0 & 14133.4 \\
Deck & 96 & 33 & 3168 & 512 & -6.8 & 5007.8 \\
\hline$\Sigma=$ & 143 & & 3740.4 & & & 19141.24
\end{tabular}

Table 3.3: Long Term Composite Section Properties

\begin{tabular}{ccccccc}
\multicolumn{7}{c}{ Long Term Composite Section } \\
Part & $\mathbf{A}\left(\mathbf{i n}^{2}\right)$ & $\mathbf{y}(\mathbf{i n})$ & $\mathbf{A y}\left(\mathbf{i n}^{3}\right)$ & $\mathbf{I}_{\mathbf{X}-\mathrm{C}}\left(\mathbf{i n}^{4}\right)$ & $\mathbf{d}_{\mathbf{Y}}(\mathbf{i n})$ & $\mathbf{I}_{\mathbf{X}-\mathbf{X}}\left(\mathbf{i n}^{4}\right)$ \\
\hline Girder & 47 & 12.2 & 572.4 & 4950.5 & 8.4 & 8293.6 \\
Deck & 96 & 33 & 1056 & 170.66667 & -12.4 & 5080.9 \\
\hline$\Sigma=$ & 143 & & 1628.4 & & 13374.577
\end{tabular}

The concrete deck attaches to the steel press-brake-formed tub girder using 6 inch long and 7/8 inch diameter shear studs welded to the top flanges of the girder. In the cross-section, there are two shear studs spaced 3 1/2 inches on each flange. They are spaced every 12 inches along the entire span of the girder. 


\subsection{LOADS \& LOAD COMBINATIONS}

For this set of design evaluations, the following permanent and transient loads are used for evaluation:

- $\quad$ DC = dead load of structural components and nonstructural attachments

o Divided into two components: DC1 which is applied to the non-composite section and DC2 which is applied to the composite section

- $\quad \mathrm{DW}=$ dead load of wearing surface and utilities

- $\mathrm{IM}=$ vehicular dynamic load allowance

o Serves to amplify the vehicular components of the HL-93 live load (i.e. the truck and tandem)

o For the fatigue limit state, $\mathrm{IM}=15 \%$ (AASHTO Table 3.6.2.1-1)

o For all other limit states, IM = 33\% (AASHTO Table 3.6.2.1-1)

- $\quad \mathrm{LL}=$ vehicular live load

o The HL-93 vehicular live load is defined in AASHTO Article 3.6.1.2

- Vehicular live loading on the roadways of bridges shall consist of a combination of the Design Truck + Design Lane Load -OR- Design Tandem + Design Lane Load

o Note that the fatigue load shall be one design truck or axles but with a constant spacing of 30.0 feet between the 32.0-kip axles (AASHTO Article 3.6.1.4.1)

The following load combinations are assessed using the permanent and transient loads mentioned previously with values for load factors derived from AASHTO Tables 3.4.1-1 and 3.4.1-2, unless otherwise specified. The ductility factor $\left(\eta_{D}\right)$, redundancy factor $\left(\eta_{R}\right)$, and the operational importance factor $\left(\eta_{I}\right)$, are taken to be 1.00 for this set of design calculations.

- Strength I: basic load combination relating to the normal vehicular use of the bridge without wind

$$
\text { o } 1.25 \mathrm{DC}+1.50 \mathrm{DW}+1.75(\mathrm{LL}+\mathrm{IM})
$$

- Strength IV: load combination relating to very high dead load to live load force effect ratios 


$$
\text { o } 1.50 \mathrm{DC}+1.50 \mathrm{DW}
$$

- Service I: load combination associated with evaluation of live load deflections (Article 3.4.2.2)

$$
\text { o } 1.00(\mathrm{LL}+\mathrm{IM})
$$

- Service II: load combination intended to control yielding of steel structures due to vehicular live load

$$
\text { o } 1.00 \mathrm{DC}+1.00 \mathrm{DW}+1.30(\mathrm{LL}+\mathrm{IM})
$$

- Fatigue I: fatigue load combination related to infinite load-induced fatigue life

$$
\text { ○ } 1.50(\mathrm{LL}+\mathrm{IM})
$$

The following loads were taken for all calculations in this design evaluation:

- Unit weight of concrete $\left(\gamma_{c}\right)=0.150 \mathrm{kcf}$

- Compressive strength of concrete (f'c) $=4.0 \mathrm{ksi}$

- Modular ratio of normal weight concrete $(n=8)$ (AASHTO Article C6.10.1.1.1b)

o These values correspond to normal weight concrete.

- Unit weight of steel $\left(\gamma_{\mathrm{s}}\right)=0.490 \mathrm{kcf}$

- $\quad$ Steel stay-in-place formwork (SIP) unit weight $=0.015 \mathrm{ksf}$

- $\quad$ Future waring surface $=0.025 \mathrm{ksf}$

- $\quad$ Weight of concrete Jersey barrier $=0.304 \mathrm{kip} / \mathrm{ft}$

\subsubsection{Component and Attachment Dead Load (DC)}

The dead load of structural components and nonstructural attachments are computed as follows. Loads such as the slab, the Jersey-style barriers, and the SIP formwork are assumed to be equally distributed to all the girders. 
Noncomposite Dead Load (DC1):

$$
\begin{array}{ll}
\text { Slab }=\frac{0.150}{4}\left[\left(\frac{8.5}{12}\right)\left(31+\frac{6}{12}\right)\right] & 0.837 \mathrm{kip} / \mathrm{ft} \\
\text { Haunch }=0.150\left[\left(\frac{2 \times 6.0}{12}\right)\left(\frac{2.0}{12}\right)\right] & 0.025 \mathrm{kip} / \mathrm{ft} \\
\text { SIP }=0.015\left[\frac{55.21-2 \times 6.0}{12}\right] & 0.054 \mathrm{kip} / \mathrm{ft} \\
\text { Girder }=\frac{0.490}{144}(47.0) &
\end{array}
$$

$$
\text { Total }=0.837+0.025+0.054+0.160
$$

$1.076 \mathrm{kip} / \mathrm{ft}$

Composite Dead Load (DC2):

$$
\text { Barrier }=\frac{2}{4}(0.304) \quad 0.152 \mathrm{kip} / \mathrm{ft}
$$$$
\text { Total }=\mathbf{0 . 3 0 4}
$$

0.304 kip/ft

The dead load of the future wearing surface is applied across the clear roadway width of 28 foot 4 inch. Loads are assumed to be equally distributed to all the girders.

Wearing Surface Dead Load (DW):

$$
\text { Wearing Surface }=\frac{0.025}{4}\left(\frac{340}{12}\right) \quad 0.177 \mathrm{kip} / \mathrm{ft}
$$

Total $=\mathbf{0 . 1 7 7}$

0.177 kip/ft 


\subsection{Multiple Presence Factors \& LiVe LoAd Distribution}

Multiple presence factors account for the probability of coincident live loadings and are listed in AASHTO Article 3.6.1.1.2. These factors are included in the empirical equations listed in AASHTO Article 4.6.2.2. The engineer must use the multiple presence factors when employing lever rule or special analysis. Note: Multiple presence factors are not applied when evaluating the fatigue limit state. These factors are listed in Table 3.4.

Table 3.4 Multiple Presence Factors (AASHTO, 2014)

\begin{tabular}{|c|c|}
\hline Number of Lanes Loaded & $\begin{array}{c}\text { Multiple Presence } \\
\text { Factor, } \mathrm{m}\end{array}$ \\
\hline 1 & 1.20 \\
\hline 2 & 1.00 \\
\hline 3 & 0.85 \\
\hline$>3$ & 0.65 \\
\hline
\end{tabular}

Live load distribution factors were employed to determine live loads on individual girders instead of a complex three-dimensional analysis. As stated in AASHTO Article 4.6.2.2, these factors are only applicable if the bridge meets certain parameters. Parameters for this bridge, including their range of applicability, which can be found in AASHTO Article 4.6.2.2, are as follows:

$$
\begin{aligned}
-0.5 & \leq \frac{N_{L}}{N_{b}} \leq 1.5 \\
0 & N_{L}=\text { Number of Lanes }=2 \\
0 & N_{b}=\text { Number of Beams }=4
\end{aligned}
$$

The parameters fall within the range of applicability found in AASHTO Article 4.6.2.2. Using these parameters, distribution factors for the analysis are found using Equations 3.1 and 3.2: Live Load Distribution Factor:

$$
D F_{L L}=0.05+0.85 \frac{N_{L}}{N_{b}}+\frac{0.425}{N_{L}}=0.688
$$


Fatigue Live Load Distribution Factor:

$$
D F_{F a t}=\frac{D F_{L L}}{m}=0.573
$$

To determine the distribution factor for live load deflections, all girders are assumed to deflect equally and the appropriate multiple presence factor shall be applied. For this bridge, with a clear roadway width of 28 foot 4 inches, this equates to two design lanes (AASHTO Article 3.6.1.1.1). With a multiple presence factor of 1.00 for two loaded lanes (AASHTO Article 3.6.1.1.2), the distribution factor appears in Equation 3.3:

$$
g=1.00\left(\frac{2}{4}\right)=0.500
$$

\subsection{Structural Analysis}

The tables in this section contain the moments, shears, and deflections resulting from structural analysis of the girder. Analyses were generated using the commercial software package LEAP CONSYS (2008), which idealizes the structure as a simple span line girder. Tables 3.5 through 3.7 show the moments, shears, and deflections from the applied dead and live loads. Tables 3.8 and 3.9 determine which Live Load Case controls, either the design truck or the design tandem, and distribute the moments and shears from the bridge system to the girders. Tables 3.10 through 3.12 factor the moments and shears calculated in the previous tables to determine the maximum shears and moments needed in the limit state evaluations. Tables 3.13 through 3.15 perform similar procedures for evaluations of deflection and fatigue cases. 
Table 3.5: Unfactored/Undistributed Moments (ft-kip)

\begin{tabular}{|c|c|c|c|c|c|c|c|c|c|c|c|c|}
\hline \multirow{3}{*}{$x(f t)$} & \multirow{3}{*}{$x / L$} & \multicolumn{3}{|c|}{ Dead Load Moments } & \multicolumn{8}{|c|}{ Live Load Moments } \\
\hline & & \multirow{2}{*}{$D C_{1}$} & \multirow{2}{*}{$D C_{2}$} & \multirow{2}{*}{$D W$} & \multicolumn{2}{|c|}{ Truck } & \multicolumn{2}{|c|}{ Lane } & \multicolumn{2}{|c|}{ Tandem } & \multicolumn{2}{|c|}{ Fatigue Truck } \\
\hline & & & & & $(+)$ & $(-)$ & $(+)$ & $(-)$ & $(+)$ & $(-)$ & $(+)$ & $(-)$ \\
\hline 0 & 0 & 0 & 0 & 0 & 0 & 0 & 0 & 0 & 0 & 0 & 0 & 0 \\
\hline 6 & 0.1 & 174.3 & 24.6 & 28.7 & 321.6 & 0 & 103.7 & 0 & 260 & 0 & 257.6 & 0 \\
\hline 12 & 0.2 & 309.9 & 43.8 & 51.0 & 556.8 & 0 & 184.3 & 0 & 460 & 0 & 428.8 & 0 \\
\hline 18 & 0.3 & 406.7 & 57.5 & 66.9 & 705.6 & 0 & 241.9 & 0 & 600 & 0 & 540.8 & 0 \\
\hline 24 & 0.4 & 464.8 & 65.7 & 76.5 & 790.4 & 0 & 276.5 & 0 & 680 & 0 & 585.6 & 0 \\
\hline 30 & 0.5 & 484.2 & 68.4 & 79.7 & 800.0 & 0 & 288.0 & 0 & 700 & 0 & 544.0 & 0 \\
\hline 36 & 0.6 & 464.8 & 65.7 & 76.5 & 790.4 & 0 & 276.5 & 0 & 680 & 0 & 585.6 & 0 \\
\hline 42 & 0.7 & 406.7 & 57.5 & 66.9 & 705.6 & 0 & 241.9 & 0 & 600 & 0 & 540.8 & 0 \\
\hline 48 & 0.8 & 309.9 & 43.8 & 51.0 & 556.8 & 0 & 184.3 & 0 & 460 & 0 & 428.8 & 0 \\
\hline 54 & 0.9 & 174.3 & 24.6 & 28.7 & 321.6 & 0 & 103.7 & 0 & 260 & 0 & 257.6 & 0 \\
\hline 60 & 1 & 0 & 0 & 0 & 0 & 0 & 0 & 0 & 0 & 0 & 0 & 0 \\
\hline
\end{tabular}

Table 3.6: Unfactored/Undistributed Shears (kip)

\begin{tabular}{|c|c|c|c|c|c|c|c|c|c|c|c|c|}
\hline \multirow{3}{*}{$x(f t)$} & \multirow{3}{*}{$x / L$} & \multicolumn{3}{|c|}{ Dead Load Shears } & \multicolumn{8}{|c|}{ Live Load Shears } \\
\hline & & \multirow{2}{*}{$D C_{1}$} & \multirow{2}{*}{$D C_{2}$} & \multirow{2}{*}{$D W$} & \multicolumn{2}{|c|}{ Truck } & \multicolumn{2}{|c|}{ Lane } & \multicolumn{2}{|c|}{ Tandem } & \multicolumn{2}{|c|}{ Fatigue Truck } \\
\hline & & & & & $(+)$ & $(-)$ & $(+)$ & $(-)$ & $(+)$ & $(-)$ & $(+)$ & $(-)$ \\
\hline 0 & 0 & 32.3 & 4.6 & 5.3 & 60.7 & 0 & 19.2 & 0 & 48.3 & 0 & 50.13 & 0 \\
\hline 6 & 0.1 & & 3.6 & 4.2 & 53.6 & -3.2 & 15.6 & -0.2 & 43.3 & -3.3 & 42.93 & -3.2 \\
\hline 12 & 0.2 & & 2.7 & 3.2 & 46.4 & -6.4 & 12.3 & -0.8 & 38.3 & -8.3 & 35.73 & -6.4 \\
\hline 18 & 0.3 & 12. & 1.8 & 2.1 & 39.2 & -11.7 & 9.4 & -1.7 & 33.3 & -13.3 & 28.8 & -10.1 \\
\hline 24 & 0.4 & 6.5 & 0.9 & 1.1 & 32.0 & -18.1 & 6.9 & -3.1 & 28.3 & -18.3 & 22.4 & -14.1 \\
\hline 30 & 0.5 & 0 & 0 & 0 & 24 & -24.0 & 4.8 & -4.8 & 23.3 & -23.3 & 18.13 & -18.1 \\
\hline 36 & 0.6 & -6.5 & -0.9 & -1.1 & 18.1 & -32.0 & 3.1 & -6.9 & 18.3 & -28.3 & 14.13 & -22.4 \\
\hline 42 & 0.7 & -12.9 & -1.8 & -2.1 & 11.7 & -39.2 & 1.7 & -9.4 & 13.3 & -33.3 & 10.13 & -28.8 \\
\hline 48 & 0.8 & -19.4 & -2.7 & -3.2 & 6.4 & -46.4 & 0.8 & -12.3 & 8.3 & -38.3 & 6.4 & -35.7 \\
\hline 54 & 0.9 & -25.8 & -3.6 & -4.2 & 3.2 & -53.6 & 0.2 & -15.6 & 3.3 & -43.3 & 3.2 & -42.9 \\
\hline 60 & 1 & -32.3 & -4.6 & -5.3 & 0 & -60.7 & 0 & -19.2 & 0 & -48.3 & 0 & -50.1 \\
\hline
\end{tabular}


Table 3.7: Unfactored/Undistributed Deflections (in)

\begin{tabular}{|c|c|cc|cc|}
\hline \multirow{3}{*}{$x(f t)$} & \multirow{3}{*}{$x / L$} & \multicolumn{4}{|c|}{ Live Load Deflections } \\
\cline { 3 - 6 } & & \multicolumn{2}{|c|}{ Truck } & \multicolumn{3}{|c|}{ Lane } \\
\cline { 3 - 6 } & $(+)$ & $(-)$ & $(+)$ & $(-)$ \\
\hline 0 & 0 & 0 & 0 & 0 & 0 \\
6 & 0.1 & 0.24 & 0 & 0.11 & 0 \\
12 & 0.2 & 0.52 & 0 & 0.2 & 0 \\
18 & 0.3 & 0.72 & 0 & 0.27 & 0 \\
24 & 0.4 & 0.84 & 0 & 0.32 & 0 \\
30 & 0.5 & 0.88 & 0 & 0.34 & 0 \\
36 & 0.6 & 0.84 & 0 & 0.32 & 0 \\
42 & 0.7 & 0.72 & 0 & 0.27 & 0 \\
48 & 0.8 & 0.52 & 0 & 0.2 & 0 \\
54 & 0.9 & 0.24 & 0 & 0.11 & 0 \\
60 & 1 & 0 & 0 & 0 & 0 \\
\hline
\end{tabular}

Table 3.8: Unfactored/Distributed Moments (ft-kip)

\begin{tabular}{|c|c|cc|c|c|c|c|c|}
\hline \multirow{2}{*}{$x(f t)$} & \multirow{2}{*}{$x / L$} & \multicolumn{2}{|c|}{1.33 Truck + Lane } & \multicolumn{2}{|c|}{ 1.33Tandem + Lane } & \multirow{2}{*}{ DF } & \multicolumn{2}{|c|}{$L L+I M$} \\
\cline { 3 - 5 } \cline { 5 - 6 } & & $(+)$ & $(-)$ & $(+)$ & $(-)$ & & $(+)$ & $(-)$ \\
\hline 0 & 0 & 0 & 0 & 0 & 0 & 0.688 & 0 & 0 \\
6 & 0.1 & 531.4 & 0 & 449.5 & 0 & 0.688 & 365.3 & 0 \\
12 & 0.2 & 924.9 & 0 & 796.1 & 0 & 0.688 & 635.8 & 0 \\
18 & 0.3 & 1180.4 & 0 & 1039.9 & 0 & 0.688 & 811.5 & 0 \\
24 & 0.4 & 1327.7 & 0 & 1180.9 & 0 & 0.688 & 912.8 & 0 \\
30 & 0.5 & 1352.0 & 0 & 1219.0 & 0 & 0.688 & 929.5 & 0 \\
36 & 0.6 & 1327.7 & 0 & 1180.9 & 0 & 0.688 & 912.8 & 0 \\
42 & 0.7 & 1180.4 & 0 & 1039.9 & 0 & 0.688 & 811.5 & 0 \\
48 & 0.8 & 924.9 & 0 & 796.1 & 0 & 0.688 & 635.8 & 0 \\
54 & 0.9 & 531.4 & 0 & 449.5 & 0 & 0.688 & 365.3 & 0 \\
60 & 1 & 0 & 0 & 0 & 0 & 0.688 & 0 & 0 \\
\hline
\end{tabular}


Table 3.9: Unfactored/Distributed Shears (kip)

\begin{tabular}{|c|c|cc|ccc|c|cc|}
\hline \multirow{2}{*}{$x(f t)$} & \multirow{2}{*}{$x / L$} & \multicolumn{2}{|c|}{1.33 Truck + Lane } & \multicolumn{3}{|c|}{ 1.33Tandem + Lane } & \multirow{2}{*}{ DF } & \multicolumn{2}{|c|}{$L L+I M$} \\
\cline { 3 - 5 } \cline { 9 - 9 } & & $(+)$ & $(-)$ & $(+)$ & $(-)$ & & $(+)$ & $(-)$ \\
\hline 0 & 0 & 100.0 & 0 & 83.4 & 0 & 0.688 & 68.7 & 0 \\
6 & 0.1 & 86.8 & -4.4 & 73.2 & -4.6 & 0.688 & 59.7 & -3.1 \\
12 & 0.2 & 74.0 & -9.3 & 63.3 & -11.9 & 0.688 & 50.9 & -6.4 \\
18 & 0.3 & 61.5 & -17.3 & 53.7 & -19.5 & 0.688 & 42.3 & -11.9 \\
24 & 0.4 & 49.5 & -27.2 & 44.6 & -27.5 & 0.688 & 34.0 & -18.7 \\
30 & 0.5 & 36.7 & -36.7 & 35.8 & -35.8 & 0.688 & 25.2 & -24.6 \\
36 & 0.6 & 27.2 & -49.5 & 27.5 & -44.6 & 0.688 & 18.9 & -30.7 \\
42 & 0.7 & 17.3 & -61.5 & 19.5 & -53.7 & 0.688 & 13.4 & -36.9 \\
48 & 0.8 & 9.3 & -74.0 & 11.9 & -63.3 & 0.688 & 8.1 & -43.5 \\
54 & 0.9 & 4.4 & -86.8 & 4.6 & -73.2 & 0.688 & 3.2 & -50.3 \\
60 & 1 & 0 & -100.0 & 0 & -83.4 & 0.688 & 0 & -57.3 \\
\hline
\end{tabular}

Table 3.10: Strength I Moments (ft-kip)

\begin{tabular}{|c|c|c|c|c|c|c|cc|}
\hline \multirow{2}{*}{$x(f t)$} & \multirow{2}{*}{$x / L^{*}$} & \multirow{2}{*}{$1.25 D C_{1}$} & \multirow{2}{*}{$1.25 D C_{2}$} & \multirow{2}{*}{$1.50 D W$} & \multicolumn{2}{|c|}{$1.75 L L+I M$} & \multicolumn{2}{|c|}{ Strength I } \\
\cline { 5 - 9 } & & & & & $(+)$ & $(-)$ & $(+)$ & $(-)$ \\
\hline 0 & 0 & 0 & 0 & 0 & 0 & 0 & 0 & 0 \\
6 & 0.1 & 217.9 & 30.8 & 43.0 & 639.4 & 0 & 931.0 & 291.7 \\
12 & 0.2 & 387.4 & 54.7 & 76.5 & 1112.7 & 0 & 1631.3 & 518.5 \\
18 & 0.3 & 508.4 & 71.8 & 100.4 & 1420.1 & 0 & 2100.7 & 680.6 \\
24 & 0.4 & 581.0 & 82.1 & 114.7 & 1597.4 & 0 & 2375.2 & 777.8 \\
30 & 0.5 & 605.3 & 85.5 & 119.5 & 1626.6 & 0 & 2436.9 & 810.2 \\
36 & 0.6 & 581.0 & 82.1 & 114.7 & 1597.4 & 0 & 2375.2 & 777.8 \\
42 & 0.7 & 508.4 & 71.8 & 100.4 & 1420.1 & 0 & 2100.7 & 680.6 \\
48 & 0.8 & 387.4 & 54.7 & 76.5 & 1112.7 & 0 & 1631.3 & 518.5 \\
54 & 0.9 & 217.9 & 30.8 & 43.0 & 639.4 & 0 & 931.0 & 291.7 \\
60 & 1 & 0 & 0 & 0 & 0 & 0 & 0 & 0 \\
\hline
\end{tabular}


Table 3.11: Strength I Shears (kip)

\begin{tabular}{|c|c|c|c|c|c|c|cc|}
\hline \multirow{2}{*}{$x(f t)$} & \multirow{2}{*}{$x / L$} & \multirow{2}{*}{$1.25 D C_{1}$} & \multirow{2}{*}{$1.25 D C_{2}$} & \multirow{2}{*}{$1.50 D W$} & \multicolumn{2}{|c|}{$1.75 L L+I M$} & \multicolumn{2}{|c|}{ Strength $I$} \\
\cline { 5 - 8 } & & & & $(+)$ & $(-)$ & $(+)$ & $(-)$ \\
\hline 0 & 0 & 40.4 & 5.7 & 8.0 & 120.3 & 0 & 174.3 & 54.0 \\
6 & 0.1 & 32.3 & 4.6 & 6.4 & 104.5 & -5.4 & 147.7 & 37.9 \\
12 & 0.2 & 24.2 & 3.4 & 4.8 & 89.0 & -11.2 & 121.4 & 21.2 \\
18 & 0.3 & 16.1 & 2.3 & 3.2 & 74.0 & -20.9 & 95.7 & 0.8 \\
24 & 0.4 & 8.1 & 1.1 & 1.6 & 59.5 & -32.7 & 70.3 & -21.9 \\
30 & 0.5 & 0 & 0 & 0 & 44.2 & -43.1 & 44.2 & -43.1 \\
36 & 0.6 & -8.1 & -1.1 & -1.6 & 33.0 & -53.7 & 22.2 & -64.5 \\
42 & 0.7 & -16.1 & -2.3 & -3.2 & 23.4 & -64.7 & 1.8 & -86.3 \\
48 & 0.8 & -24.2 & -3.4 & -4.8 & 14.3 & -76.1 & -18.2 & -108.5 \\
54 & 0.9 & -32.3 & -4.6 & -6.4 & 5.6 & -88.1 & -37.6 & -131.3 \\
60 & 1 & -40.4 & -5.7 & -8.0 & 0 & -100.4 & -54.0 & -154.4 \\
\hline
\end{tabular}

Table 3.12: Service II Moments (ft-kip)

\begin{tabular}{|c|c|c|c|c|c|c|cc|}
\hline \multirow{2}{*}{$x(f t)$} & \multirow{2}{*}{$x / L$} & \multirow{2}{*}{$1.00 \mathrm{DC}_{1}$} & \multirow{2}{*}{$1.00 \mathrm{DC}_{2}$} & \multirow{2}{*}{$1.00 \mathrm{DW}$} & \multicolumn{2}{|c|}{$1.30 \mathrm{LL}+\mathrm{IM}$} & \multicolumn{2}{|c|}{ Service II } \\
\cline { 5 - 9 } & & & & & $(+)$ & $(-)$ & $(+)$ & $(-)$ \\
\hline 0 & 0 & 0 & 0 & 0 & 0 & 0 & 0 & 0 \\
6 & 0.1 & 174.3 & 24.6 & 28.7 & 474.9 & 0 & 702.6 & 227.6 \\
12 & 0.2 & 309.9 & 43.8 & 51.0 & 826.6 & 0 & 1231.2 & 404.6 \\
18 & 0.3 & 406.7 & 57.5 & 66.9 & 1055.0 & 0 & 1586.0 & 531.1 \\
24 & 0.4 & 464.8 & 65.7 & 76.5 & 1186.6 & 0 & 1793.6 & 607.0 \\
30 & 0.5 & 484.2 & 68.4 & 79.7 & 1208.4 & 0 & 1840.6 & 632.3 \\
36 & 0.6 & 464.8 & 65.7 & 76.5 & 1186.6 & 0 & 1793.6 & 607.0 \\
42 & 0.7 & 406.7 & 57.5 & 66.9 & 1055.0 & 0 & 1586.0 & 531.1 \\
48 & 0.8 & 309.9 & 43.8 & 51.0 & 826.6 & 0 & 1231.2 & 404.6 \\
54 & 0.9 & 174.3 & 24.6 & 28.7 & 474.9 & 0 & 702.6 & 227.6 \\
60 & 1 & 0 & 0 & 0 & 0 & 0 & 0 & 0 \\
\hline
\end{tabular}


Table 3.13: Service I Deflections (in)

\begin{tabular}{|c|c|ccc|c|c|c|cc|}
\hline \multirow{2}{*}{$x(f t)$} & \multirow{2}{*}{$x / L$} & \multicolumn{3}{|c|}{ Truck } & \multicolumn{2}{|c|}{ 0.25Truck+ Lane } & \multirow{2}{*}{ DF } & \multicolumn{2}{|c|}{ Service I } \\
\cline { 3 - 5 } \cline { 5 - 6 } & & $(+)$ & $(-)$ & $(+)$ & $(-)$ & & $(+)$ & $(-)$ \\
\hline 0 & 0 & 0 & 0 & 0 & 0 & 0.5 & 0 & 0 \\
6 & 0.1 & 0.32 & 0 & 0.19 & 0 & 0.5 & 0.16 & 0 \\
12 & 0.2 & 0.69 & 0 & 0.37 & 0 & 0.5 & 0.35 & 0 \\
18 & 0.3 & 0.96 & 0 & 0.51 & 0 & 0.5 & 0.48 & 0 \\
24 & 0.4 & 1.12 & 0 & 0.60 & 0 & 0.5 & 0.56 & 0 \\
30 & 0.5 & 1.17 & 0 & 0.63 & 0 & 0.5 & 0.59 & 0 \\
36 & 0.6 & 1.12 & 0 & 0.60 & 0 & 0.5 & 0.56 & 0 \\
42 & 0.7 & 0.96 & 0 & 0.51 & 0 & 0.5 & 0.48 & 0 \\
48 & 0.8 & 0.69 & 0 & 0.37 & 0 & 0.5 & 0.35 & 0 \\
54 & 0.9 & 0.32 & 0 & 0.19 & 0 & 0.5 & 0.16 & 0 \\
60 & 1 & 0 & 0 & 0 & 0 & 0.5 & 0 & 0 \\
\hline
\end{tabular}

Table 3.14: Fatigue I Moments (ft-kip)

\begin{tabular}{|c|c|ccc|c|c|c|}
\hline \multirow{2}{*}{$x(f t)$} & \multirow{2}{*}{$x / L$} & \multicolumn{2}{|c|}{$L L+I M$} & \multirow{2}{*}{$\mathrm{DF}$} & \multicolumn{2}{|c|}{$1.50(L L+I M)$} \\
\cline { 3 - 4 } \cline { 5 - 6 } & & $(+)$ & $(-)$ & & $(+)$ & $(-)$ \\
\hline 0 & 0 & 0 & 0 & 0.573 & 0 & 0 \\
6 & 0.1 & 296.2 & 0 & 0.573 & 254.6 & 0 \\
12 & 0.2 & 493.1 & 0 & 0.573 & 423.8 & 0 \\
18 & 0.3 & 621.9 & 0 & 0.573 & 534.5 & 0 \\
24 & 0.4 & 673.4 & 0 & 0.573 & 578.7 & 0 \\
30 & 0.5 & 625.6 & 0 & 0.573 & 537.6 & 0 \\
36 & 0.6 & 673.4 & 0 & 0.573 & 578.7 & 0 \\
42 & 0.7 & 621.9 & 0 & 0.573 & 534.5 & 0 \\
48 & 0.8 & 493.1 & 0 & 0.573 & 423.8 & 0 \\
54 & 0.9 & 296.2 & 0 & 0.573 & 254.6 & 0 \\
60 & 1 & 0 & 0 & 0.573 & 0 & 0 \\
\hline
\end{tabular}


Table 3.15: Fatigue I Shears (kip)

\begin{tabular}{|c|c|c|c|c|c|c|}
\hline \multirow{2}{*}{$x(f t)$} & \multirow{2}{*}{$x / L$} & \multicolumn{2}{|c|}{$L L+I M$} & \multirow{2}{*}{ DF } & \multicolumn{2}{|c|}{$1.50(L L+I M)$} \\
\cline { 3 - 4 } \cline { 5 - 6 } & & $(+)$ & $(-)$ & & $(+)$ & $(-)$ \\
\hline 0 & 0 & 57.7 & 0 & 0.573 & 49.5 & 0 \\
6 & 0.1 & 49.4 & -3.7 & 0.573 & 42.4 & -3.2 \\
12 & 0.2 & 41.1 & -7.4 & 0.573 & 35.3 & -6.3 \\
18 & 0.3 & 33.1 & -11.7 & 0.573 & 28.5 & -10.0 \\
24 & 0.4 & 25.8 & -16.3 & 0.573 & 22.1 & -14.0 \\
30 & 0.5 & 20.9 & -20.9 & 0.573 & 17.9 & -17.9 \\
36 & 0.6 & 16.3 & -25.8 & 0.573 & 14.0 & -22.1 \\
42 & 0.7 & 11.7 & -33.1 & 0.573 & 10.0 & -28.5 \\
48 & 0.8 & 7.4 & -41.1 & 0.573 & 6.3 & -35.3 \\
54 & 0.9 & 3.7 & -49.4 & 0.573 & 3.2 & -42.4 \\
60 & 1 & 0 & -57.7 & 0.573 & 0 & -49.5 \\
\hline
\end{tabular}

\subsection{Limit StaTe EVALUATIONS}

The limit states pertaining to the performance of the tub girders are discussed in this section. It should be noted, for all limit states, according to AASHTO Article 6.5.4.2, the resistance factor for flexure $\left(\phi_{f}\right)$ and for shear $\left(\phi_{v}\right)$ are both taken to be 1.00. The hybrid factor $\left(R_{h}\right)$ is taken as 1.00 since the girders are fully comprised of 50-ksi steel.

\subsubsection{Cross Section Proportion Limits (AASHTO Article 6.11.2)}

The girders in this design evaluation were evaluated to meet the cross-section proportion limits of AASHTO Article 6.11.2. These limits are divided into two main categories: web proportions and flange proportions.

For webs without longitudinal stiffeners, the following limits are employed from AASHTO Articles 6.10.2.1.1:

$$
\frac{D}{t_{w}} \leq 150
$$


Where:

$D=$ Depth of web (in)

$t_{w}=$ Thickness of web (in)

$\frac{26}{0.5} \leq 150$

$52 \leq 150 \therefore O K$

The following limits are employed for flange proportions:

$$
\frac{b_{f}}{2 t_{f}} \leq 12.0
$$

Where:

$$
\begin{aligned}
& b_{f}=\text { width of flange (in) } \\
& t_{f}=\text { Thickness of flange (in) }
\end{aligned}
$$

$$
\frac{6}{2 * 0.5} \leq 12.0
$$

$6 \leq 12.0 \therefore O K$

$b_{f} \geq D / 6$

Eq. 3.6

$6 \geq \frac{26}{6}$

$6 \geq 4.33 \therefore O K$ 
Note the top flange of the tub girder is continuously supported during fabrication and construction. AASHTO Equation 6.11.2.2-3 ensures some restraint will be provided by the flanges against web shear buckling. This restraint is provided by the reinforced concrete deck, which is cast directly on the flange.

\subsubsection{Constructability}

The tub girder is continuously supported during fabrication and construction. No constructability checks are required because no significant loading occurs during the fabrication of the modular unit.

\subsubsection{Service Limit State}

The service limit state evaluated according to Article 6.11.4 heavily refer to Articles 6.10.4.1 (governing elastic deformations) and 6.10.4.2 (governing permanent deformations).

\subsubsection{Permanent Deformations}

The intent of the service limit state is to limit stresses and deformations under regular operating conditions. This is accomplished by limiting the levels of stress the member experiences to prevent localized yielding. As per AASHTO Article 6.11.4, the provisions of AASHTO Article 6.10.4 and its respective equations apply, except the $f_{l}$ term in Equation 3.8 shall equal zero.

For the top steel flange of composite sections:

$$
f_{f} \leq 0.95 R_{h} F_{y f}
$$

For the bottom steel flange of composite sections:

$$
f_{f}+\frac{f_{l}}{2} \leq 0.95 R_{h} F_{y f}
$$


Where:

$f_{f}=$ flange stress at the section under consideration due to the Service II loads calculated without consideration flange lateral bending (ksi)

$f_{l}=$ flange lateral bending stress at the section under consideration due to the Service II loads determined as specified in AASHTO Article 6.10.1.6 (ksi)

$R_{h}=$ hybrid factor determined as specified in AASHTO Article 6.10.1.10.1

$F_{y f}=$ specified minimum yield strength of a flange (ksi)

The first step in evaluating the girders' performance under permanent deformation limits is to determine the girders' service level stresses. This will be derived from gravity and vehicular loadings, as lateral loads are not being considered at the service limit state in this design evaluation.

From the analysis results, the following Service II moments, from Table 3.12, were found:

$$
1.00 M_{D C 1}=484.2 \text { ft kip }
$$

$1.00 M_{D C 2}=68.4$ ft kip

$$
1.00 M_{D W}=79.65 \mathrm{ft} \mathrm{kip}
$$

$$
1.30 M_{L L+I M}=1208.35 \text { ft kip }
$$

Using these moments, Service II stresses for the top and bottom flange are found in Equations 3.9 and 3.10. The distances from the centroid and the moments of inertia for each portion of load corresponding to the non-composite, short-term composite, and long-term composite sections can be found in Tables 3.1 through 3.3. 
Top Flange:

$$
f_{f}=\frac{(484.2)(12)(14.82)}{4950.48}+\frac{(68.4+79.65)(12)(6.39)}{13374.58}+\frac{(1208.35)(12)(0.84)}{19141.24}=
$$

$18.88 \mathrm{ksi}$

$$
f_{f} \leq 0.95 R_{h} F_{y f}
$$

$$
18.88<0.95(1.0)(50) \Rightarrow 18.88 k s i<47.5 k s i \quad \therefore \text { OK }(\text { Ratio }=0.398)
$$

Bottom Flange:

$$
f_{f}=\frac{(484.2)(12)(12.18)}{4950.48}+\frac{(68.4+79.65)(12)(20.61)}{13374.58}+\frac{(1208.35)(12)(26.16)}{19141.24}=
$$

\section{$36.85 \mathrm{ksi}$}

$$
\begin{aligned}
& f_{f}+\frac{f_{l}}{2} \leq 0.95 R_{h} F_{y f} \\
& 36.85+\frac{0}{2}<0.95(1.0)(50) \Rightarrow 36.85 k s i<47.5 \text { ksi } \therefore \text { OK }(\text { Ratio }=0.776)
\end{aligned}
$$

Therefore, according to Equations 3.7 and 3.8 respectively, the flanges are shown to meet the requirements for permanent deformations at the service limit state.

\subsubsection{Elastic Deformations}

Many states’ Departments of Transportation and owner agencies choose to invoke optional live load deflection criteria meant to ensure user comfort in addition to the limit states set forth for permanent deformations. This optional limit is also evaluated. AASHTO Article 2.5.2.6.2 states deflection criteria that may be used. For bridges subjected to vehicular loads only, a limit of $L / 800$ is specified (Figure 3.4). For a span length of 60 feet, this equates to a live load deflection of 0.9 
inches. From analysis results, a maximum live load deflection of 0.585 inches was determined. Therefore, this meets elastic deformation requirements $($ Ratio $=0.650)$.

- Vehicular load, general .............................Span/800,

- Vehicular and pedestrian loads ............... Span/1000,

- Vehicular load on cantilever arms ............................

Span/300, and

- Vehicular and pedestrian loads on cantilever arms $\operatorname{Span} / 375$.

Figure 3.4: Live Load Deflection Limits (AASHTO, 2014)

\subsubsection{Fatigue Limit State}

The intent of the fatigue limit state is to control crack growth under cyclic loading conditions by limiting the range of live load stress $(\Delta f)$ to which the steel members are subjected. Specifically, load induced fatigue categories must satisfy the limit shown in Equation 3.6. For the limit, the load factor $(\gamma)$ and the nominal fatigue resistance $\left((\Delta F)_{n}\right)$ associated with the fatigue limit state are a function of the number of stress cycles to which the girder is subjected.

$$
\gamma(\Delta f) \leq(\Delta F)_{N}
$$

Where:

$\gamma=$ load factor specified in AASHTO Table 3.4.1-1 for the fatigue load combination

$(\Delta f)=$ force effect, live load stress range due to the passage of the fatigue load as specified in AAASHTO Article 3.6.1.4 (ksi)

$(\Delta F)_{n}=$ nominal fatigue resistance as specified in AASHTO Article 6.6.1.2.5 (ksi) 
AASHTO Article 6.11.5 states the provisions of AASHTO Article 6.10.5 apply where AASHTO Article 6.10.5.1 requires fatigue be investigated in accordance with AASHTO Article 6.6.1, which states the live load stress range be less than the fatigue resistance. The $(\Delta F)_{n}$ varies based on the fatigue category to which a particular member or detail belongs. The nominal fatigue resistance is taken using the following equations:

For the Fatigue I load combination (infinite life):

$$
(\Delta F)_{n}=(\Delta F)_{T H}
$$

For the Fatigue II load combination (finite life):

$$
\begin{aligned}
& (\Delta F)_{n}=\left(\frac{A}{N}\right)^{\frac{1}{3}} \\
& N=(365)(75) n(A D T T)_{S L}
\end{aligned}
$$

Where:

$A=$ constant taken from AASHTO Table 6.6.1.2.5-a $\left(\mathrm{ksi}^{3}\right)$

$n=$ number of stress range cycles per truck pass taken from AASHTO Table 6.6.1.2.5-2

$(A D T T)_{S L}=$ single-lane $A D T T$ as specified in AASHTO Article 3.6.1.4

$(\Delta F)_{T H}=$ constant-amplitude fatigue threshold taken from AASHTO Table 6.6.1.2.5-6 (ksi)

For this design evaluation, the detail is the bottom bend in the steel plate. According to AASHTO Table 6.6.1.2.3-1 Section 1, this detail is listed with a fatigue category B. Fatigue category B is chosen to be conservative because it is unknown if the steel used will be galvanized or weathering steel and otherwise meets the description in described in Section 1.2 of Table 6.6.1.2.3-1. For a fatigue category $\mathrm{B}$, a constant amplitude fatigue threshold, $(\Delta F)_{T H}=16 \mathrm{ksi}$ (AASHTO Table 6.6.1.2.5-3), is obtained. 
Values for cycles per truck passage $(n)$ are listed in AASHTO Table 6.6.1.2.5-2. For a simple-span girder with a span length larger than 40 feet, $n$ is taken as 1.0.

To determine the single-lane average daily truck traffic $\left((A D T T)_{S L}\right)$, a value of the average daily truck traffic (ADTT) is assumed. For this design example, an ADTT of 4000 trucks per day was assumed. AASHTO Table 3.6.1.4.2-1 lists $p$ values, which are fractions of ADTT that can be expected in a single lane. For a two-lane bridge, $p=0.85$. Therefore, according to Equation 3.15, $(A D T T)_{S L}$ can be easily evaluated.

$$
(A A D T)_{S L}=p(A A D T)=0.85\left(4000 \frac{\text { trucks }}{\text { day }}\right)=3400 \frac{\text { trucks }}{\text { day }}
$$

AASHTO Table 6.6.1.2.3-2 lists ADTT values, which are equivalent to infinite life. Specifically, AASHTO Article 6.6.1.2.3 states that when the actual (ADTT)SL value is larger than that listed in the table, the detail in question shall be designed for the Fatigue I load combination for infinite life. For a fatigue category B, a value of 860 trucks per day is listed. Therefore, the details chosen for these design evaluations are evaluated for the Fatigue I load combination for infinite life.

From the previously determined Factored Fatigue I moments, a maximum moment of 578.7 ft-kip was determined from Table 3.14. Since the structure being analyzed is a simple span bridge, a minimum fatigue moment of zero was found. Therefore, a fatigue stress range can be found for both the top flange and bottom flange by determining the stress resulting from the calculated moment in Equations 3.16 and 3.17, respectively. As shown in the following check for fatigue, the bends in the tub girder perform satisfactorily. The distances from the flange being analyzed can be calculated and the short-term composite moment of inertia can be found in Tables 3.1 and 3.2.

Top Flange:

$$
\begin{aligned}
& \gamma(\Delta f)=\frac{578.7(12)(0.84)}{19141.24}=0.31 k s i \\
& 0.31 k s i<16.0 k s i \therefore \text { OK }(\text { Ratio }=0.019)
\end{aligned}
$$




\section{Bottom Flange:}

$$
\gamma(\Delta f)=\frac{578.7(12)(26.16)}{19141.24}=9.49 k s i
$$

$$
9.49 k s i<16.0 k s i \therefore \text { OK }(\text { Ratio }=0.593)
$$

\subsubsection{Strength Limit State}

The intent of the strength limit state is to ensure the structure has adequate strength and stability when subjected to maximum factored loads. For a composite section in positive flexure, sections must meet flexural resistance requirements and the ductility requirement outlined in AASHTO Article 6.10.7.3. The section must have adequate shear capacity under the maximum factored loads. The computation of the girder's flexural resistance, shear resistance, and ductility are discussed in Section 3.3 Girder Geometry, along with the factored loads and force effects these sections must withstand.

\subsubsection{Flexure}

For flexure, in order to determine a section's capacity, a determination must be made whether the section is classified as compact or noncompact. For this determination, the section's plastic moment capacity must be calculated. The plastic moment capacity of the section is evaluated according to the provisions of AASHTO Article D6.1. For this evaluation, the reinforcement in the concrete slab is conservatively neglected.

The first step in determining the section's plastic moment capacity is to determine the plastic forces in each of section's components, as seen in Equations 3.18 through 3.23.

$$
\begin{aligned}
& P_{S}=0.85 f_{c}^{\prime} b_{s} t_{s}=0.85(4)(96)(8.00)=2611.2 \mathrm{kip} \\
& P_{T F}=F_{y} A_{T F}=(50)(12)=300 \mathrm{kip}
\end{aligned}
$$




$$
\begin{aligned}
& P_{T B}=2 F_{y} A_{\text {bend }}=2(50)(1.8)=182.3 \mathrm{kip} \\
& P_{W}=F_{y} A_{W}=2(50)(11.5)=1151.1 \mathrm{kip} \\
& P_{B B}=2 F_{y} A_{\text {bend }}=2(50)(1.8)=182.3 \mathrm{kip} \\
& P_{B F}=F_{y} A_{B F}=(50)(10.7)=534.3 \mathrm{kip}
\end{aligned}
$$

Where:

$P_{S}=$ plastic compressive force in concrete deck (kip)

$f^{\prime}{ }_{c}=$ minimum specified 28-day compressive strength (ksi)

$b_{s}=$ effective width of concrete deck (in)

$t_{s}=$ thickness of concrete deck (in)

$P_{T F}=$ plastic force in top flange of steel girder (kip)

$F_{y}=$ yield strength of steel used in steel girder (ksi)

$A_{T F}=$ cross sectional area of top flange $\left(i^{2}\right)$

$P_{T B}=$ plastic force in top bend of steel girder (kip)

$A_{T B}=$ cross sectional area of top bend $\left(i^{2}\right)$

$P_{W}=$ plastic force in web of steel girder (kip)

$A_{W}=$ cross sectional area of web $\left(i^{2}\right)$

$P_{B B}=$ plastic force in bottom bend of steel girder (kip)

$A_{B B}=$ cross sectional area of bottom bend (in $\left.{ }^{2}\right)$

$P_{B F}=$ plastic force in bottom flange of steel girder (kip)

$A_{B F}=$ cross sectional area of bottom flange $\left(\mathrm{in}^{2}\right)$ 
Next, the location of the plastic neutral axis (PNA) must be determined. AASHTO Table D6.1 gives a straightforward procedure, using Equations 3.24 and 3.25, on determining the location of the PNA and is adopted in this design example.

Case I (PNA is in the web)

$$
P_{B F}+P_{B B}+P_{W} \geq P_{T B}+P_{T F}+P_{S}
$$

$1867.7<3093.5 \therefore P N A$ is not in the web

Case II (PNA is in the top flange)

$$
P_{B F}+P_{B B}+P_{W}+P_{T B}+P_{T F} \geq P_{S}
$$

\section{$2350<2611.2 \therefore P N A$ is not in the top flange}

Therefore, the PNA is in the concrete slab and its location measured from the top of the structural slab $(Y)$ is found in Equation 3.26:

$$
\begin{aligned}
& \bar{Y}=\left(t_{s}\right)\left[\frac{P_{B F}+P_{B B}+P_{W}+P_{T B}+P_{T F}}{P_{\text {Slab }}}\right] \\
& \bar{Y}=(8)\left[\frac{534.3+182.3+1151.1+182.3+300}{2611.2}\right]=7.20 \mathrm{in}
\end{aligned}
$$

Next, the distances of the individual components from the location of the PNA are computed.

$$
\begin{aligned}
& d_{S}=7.20-\left(\frac{8.00}{2}\right)=3.200 \mathrm{in} \\
& d_{T F}=(8.00-7.20)+2.00+(27.00-26.75)=3.05 \mathrm{in}
\end{aligned}
$$




$$
\begin{aligned}
& d_{T B}=(8.00-7.20)+2.00+(27.00-26.00)=3.78 \mathrm{in} \\
& d_{W}=(8.00-7.200)+2.00+(27.00-13.50)=16.30 \mathrm{in} \\
& d_{B B}=(8.00-7.20)+2.00+(27.00-1.00)=28.82 \mathrm{in} \\
& d_{B F}=(8.00-7.20)+2.00+(27.00-0.25)=29.55 \mathrm{in}
\end{aligned}
$$

Where:

$d_{S}=$ distance from the plastic neutral axis to centroid of concrete slab (in)

$d_{T F}=$ distance from the plastic neutral axis to centroid of top flange (in)

$d_{T B}=$ distance from the plastic neutral axis to centroid of top bend (in)

$d_{W}=$ distance from the plastic neutral axis to centroid of web (in)

$d_{B B}=$ distance from the plastic neutral axis to centroid of bottom bend (in)

$d_{B F}=$ distance from the plastic neutral axis to centroid of bottom flange (in)

The plastic moment of the composite section $\left(M_{p}\right)$ is then evaluated using Equation 3.27.

$$
\begin{aligned}
& M_{p}=\left(\frac{\overline{Y^{2}} P_{S}}{2 t_{s}}\right)+\left[P_{T F} d_{T F}+P_{T B} d_{T B}+P_{W} d_{W}+P_{B B} d_{B B}\right. \\
& \left.+P_{B F} d_{B F}\right] \\
& M_{p}=\left(\frac{(7.200)^{2} * 2611.2}{2(8.00)}\right) \\
& +[(300)(3.050)+(182.3)(3.782)+(1151.1)(16.300) \\
& +(182.3)(28.818)+(543.3)(29.550)] \\
& M_{p}=49870.2 \text { in kip }=4155.9 \mathrm{ft} \mathrm{kip}
\end{aligned}
$$


For a composite section in positive flexure to be considered compact, according to AASHTO Article 6.10.6.2.2, the section must meet three requirements. The first requirement states the minimum yield strengths of the flanges must not exceed $70.0 \mathrm{ksi}$, which is met by the $50 \mathrm{ksi}$ steel used throughout this design example. The second requirement is that the web satisfies AASHTO Article 6.10.2.1.1, which was evaluated earlier in Section 3.7.1 Cross Section Proportion Limits. The third requirement is that the section satisfies the web slenderness limit found in Equation 3.12.

$$
\frac{2 D_{c p}}{t_{w}} \leq 3.76 \sqrt{\frac{E}{F_{y c}}}
$$

Where:

$D_{c p}=$ depth of the web in compression at the plastic moment determined in AASHTO Article D6.3.2 (in)

$t_{w}=$ thickness of web (in)

$E=$ modulus of elasticity of steel (ksi)

$F_{y c}=$ minimum compression strength of compression flange (ksi)

It was previously determined the PNA was in the concrete slab. Therefore, $D_{c p}=0$, satisfying the third requirement. Since AASHTO Article 6.10.6.2.2 requirements have been met, this section is classified as compact. For compact composite sections in positive flexure, AASHTO Article 6.10.7.1.2 states the nominal flexural resistance $\left(M_{n}\right)$ is computed using Equations 3.29 and 3.30:

$$
\begin{aligned}
& \text { If } D_{p} \leq 0.1 D_{t} \text {, then: } \\
& M_{n}=M_{p}
\end{aligned}
$$


Otherwise:

$$
M_{n}=M_{p}\left(1.07-0.7 \frac{D_{p}}{D_{t}}\right)
$$

Where:

$D_{p}=$ distance from the top of the concrete deck to the neutral axis of the composite section at the plastic moment (in)

$D_{t}=$ total depth of the composite section (in)

$M_{n}=$ nominal flexural resistance (kip-in)

$$
D_{p}=\bar{Y}=7.20 \mathrm{in}
$$

$D_{t}=8.00+2.00+27.00=37.00$ in

$0.1 D_{t}=3.70 \mathrm{in}$

$D_{p}>0.1 D_{t}$

Therefore, solving Equation 3.30:

$$
M_{n}=4155.9\left(1.07-0.7 \frac{7.20}{37.0}\right)=3880.7 \mathrm{ft} \mathrm{kip}
$$

To satisfy strength limit state requirements, the section must satisfy the following relation:

$$
M_{u}+\frac{1}{3} f_{l} S_{x t} \leq \phi_{f} M_{n}
$$

Where:

$\phi_{f}=$ resistance factor for flexure specified in AASHTO Article 6.5.4.2

$f_{l}=$ flange lateral bending stress determined as specified in AASHTO Article 6.10.1.6 (ksi) 
$M_{n}=$ nominal flexural resistance of the section determined as specified in AASHTO Article 6.10.1.6 (kip-in)

$M_{u}=$ bending moment about the major-axis of the cross-section determined as specified in AASHTO Article 6.10.1.6 (kip-in)

$M_{y t}=$ yield moment with respect to the tension flange determined as specified in AASHTO Article D6.2 (kip-in)

$S_{x t}=$ elastic section modulus about the major axis of the section to the tension flange (in ${ }^{3}$ )

Due to wind forces and other lateral loads being neglected at the finished state, $f_{l}=0$. From the moments generated for this girder, a maximum Strength I bending moment of $2436.9 \mathrm{ft}-\mathrm{kip}$ was found, as seen in Table 3.10, indicating this girder meets strength limit state requirements of the modified Equation 3.31 for flexure.

$$
M_{u} \leq \phi_{f} M_{n}
$$

2436.9 ft kip $<1.00(3880.7$ ft kip $) \therefore$ OK $($ Ratio $=0.628)$

\subsubsection{2 $\underline{\text { Shear }}$}

The provisions of AASHTO Article 6.11.9 are applied to determine whether sections meet strength limit state requirements for shear. The first step in finding shear is to determine the plastic shear capacity of the web, which is found using Equation 3.32. Note that $D$ in AASHTO Article 6.10.9 shall be taken as the depth of web plate measured along the slope.

$$
\begin{aligned}
& V_{p}=0.58 F_{y w} D t_{w} \\
& V_{p}=0.58(50)(23.02)(0.5)=333.8 \mathrm{kip}
\end{aligned}
$$

Where:

$$
V_{p}=\text { plastic shear force (kip) }
$$


The plastic shear capacity of the web is then modified by $C$ to obtain the nominal shear resistance. $C$ is the ratio of shear-buckling resistance to shear yield strength and is a function of the slenderness of the web. For this computation, a shear buckling coefficient $(k)$ is introduced. However, as this web is unstiffened, $k$ is taken as a constant value equal to 5.0. Therefore, $C$ is determined using Equation 3.33.

$$
\begin{aligned}
& \frac{D}{t_{w}} \leq 1.12 \sqrt{\frac{E k}{F_{y w}}} \\
& \frac{23.02}{0.5} \leq 1.12 \sqrt{\frac{(29000)(5.0)}{(50)}} \\
& 46.0 \leq 60.3
\end{aligned}
$$

Therefore:

$$
C=1.0
$$

The nominal shear capacity $\left(V_{n}\right)$ is then determined using Equation 3.34 .

$$
\begin{aligned}
& V_{n}=V_{c r}=C V_{p} \\
& V_{n}=(1.0)(333.8)=333.8 \mathrm{kip}
\end{aligned}
$$

From the shears generated for this girder, a maximum Strength I shear of 196.5 kip was found in Table 3.11. Equation 3.35 indicates the girder meets strength limit state requirements for shear.

$$
V_{u} \leq \phi_{v} V_{n}
$$

$174.3 \mathrm{kip} \leq(1.0)(333.8 \mathrm{kip}) \therefore$ OK $($ Ratio $=0.522)$ 
Where:

$\phi_{v}=$ resistance factor for shear specified in AASHTO Article 6.5.4.2

$V_{n}=$ nominal shear resistance (kip)

$V_{u}=$ shear in the web at the section under consideration due to the factored loads (kip)

\subsubsection{Ductility}

An additional ductility requirement is placed on composite sections in positive flexure. Specifically, sections shall meet the requirements in Equation 3.36.

$$
D_{p} \leq 0.42 D_{t}
$$

$$
7.20 \leq(0.42)(37.0)
$$

7.20 in $\leq 15.4$ in $\therefore$ OK $($ Ratio $=0.463)$

For this requirement, using previously determined values, the section performs satisfactorily.

\subsubsection{Shear Connectors}

The fatigue shear resistance of an individual shear stud $\left(Z_{r}\right)$ is based on the Fatigue I load combination because the $(A D T T)_{S L}$ is greater than 960 trucks per day. Equation 3.37 is used to calculate the fatigue shear resistance of an individual shear stud. The diameter of the shear studs used in this design example $(d)$ are 7/8 inch.

$$
Z_{r}=5.5 d^{2}
$$




$$
Z_{r}=5.5\left(\frac{7}{8}\right)^{2}=4.21 \mathrm{kip}
$$

The next step in determining the maximum distance between shear studs is to determine the first moment of the deck with respect to the neutral axis of the composite section $(Q)$. The distance from the centroid of the deck to the centroid of the composite section is 6.84 inches and the transformed area of the deck is $47 \mathrm{in}^{2}$.

$$
Q=(6.84 i n)\left(47 i n^{2}\right)=656.96 i n^{3}
$$

The Vertical Shear Force Range Under the Applicable Fatigue Load $\left(V_{f}\right)$ is found by finding the difference between the maximum and the minimum shears for each tenth point along the span, as seen in Table 3.16.

Table 3.16: Calculation of Vertical Shear Force Range

\begin{tabular}{|c|c|c|c|c|}
\hline \multirow{2}{*}{$x(f t)$} & \multirow{2}{*}{$x / L$} & \multicolumn{2}{|c|}{$1.50(L L+I M)$} & \multirow{2}{*}{$V_{\mathbf{f}}$ (kip) } \\
\cline { 3 - 4 } & & $(+)$ & $(-)$ & \\
\hline 0 & 0 & 49.5 & 0.0 & 49.5 \\
6 & 0.1 & 42.4 & -3.2 & 45.6 \\
12 & 0.2 & 35.3 & -6.3 & 41.6 \\
18 & 0.3 & 28.5 & -10.0 & 38.5 \\
24 & 0.4 & 22.1 & -14.0 & 36.1 \\
30 & 0.5 & 17.9 & -17.9 & 35.8 \\
36 & 0.6 & 14.0 & -22.1 & 36.1 \\
42 & 0.7 & 10.0 & -28.5 & 38.5 \\
48 & 0.8 & 6.3 & -35.3 & 41.6 \\
54 & 0.9 & 3.2 & -42.4 & 45.6 \\
60 & 1 & 0.0 & -49.5 & 49.5 \\
\hline
\end{tabular}


The Longitudinal Fatigue Shear Range per Unit Length $\left(V_{f a t}\right)$ is calculated using the Vertical Shear Force Ranges at tenth points by evaluating Equation 3.38. The Horizontal Fatigue Shear Range per Unit Length $\left(V_{s r}\right)$ is simply the same as the Longitudinal Fatigue Shear Range per Unit Length because the radial shear due to curvature may be conservatively neglected for box sections as stated in AASHTO Section C6.11.10, as seen in Equation 3.39.

$$
V_{\text {fat }}=\frac{V_{f} Q}{I}
$$

Where:

$V_{f}=$ vertical shear force range under the applicable fatigue load

$I=$ moment of inertia of the short-term composite section (in $\left.{ }^{4}\right)$

$$
V_{s r}=\sqrt{\left(V_{f a t}\right)^{2}+\left(F_{f a t}\right)^{2}}
$$

Therefore, the maximum pitch $(p)$, or distance between shear studs, required to meet fatigue requirements, at tenth points, for shear studs is calculated using Equation 3.40. The minimum pitch values at tenth points can be seen in Table 3.17.

$$
p \leq \frac{n Z_{r}}{V_{s r}}
$$

Where:

$n=$ number of shear connectors in a cross-section 
Table 3.17: Calculation of Minimum Pitch

\begin{tabular}{|c|c|c|c|c|c|}
\hline \multirow{2}{*}{$x(f t)$} & \multirow{2}{*}{$x / L$} & \multicolumn{3}{|c|}{ Stresses (ksi) } & \multirow{2}{*}{$\boldsymbol{p}$ (in) } \\
\cline { 3 - 5 } & & $\mathrm{V}_{\text {fat }}$ & $\mathrm{H}_{\mathrm{fat}}$ & $\mathrm{V}_{\mathrm{sr}}$ & \\
\hline 0 & 0 & 1.700 & 0 & 1.700 & 9.91 \\
6 & 0.1 & 1.565 & 0 & 1.565 & 10.76 \\
12 & 0.2 & 1.429 & 0 & 1.429 & 11.79 \\
18 & 0.3 & 1.321 & 0 & 1.321 & 12.75 \\
24 & 0.4 & 1.239 & 0 & 1.239 & 13.59 \\
30 & 0.5 & 1.230 & 0 & 1.230 & 13.69 \\
36 & 0.6 & 1.239 & 0 & 1.239 & 13.59 \\
42 & 0.7 & 1.321 & 0 & 1.321 & 12.75 \\
48 & 0.8 & 1.429 & 0 & 1.429 & 11.79 \\
54 & 0.9 & 1.565 & 0 & 1.565 & 10.76 \\
60 & 1 & 1.700 & 0 & 1.700 & 9.91 \\
\hline
\end{tabular}

Linear interpolation reveals a 12 inch pitch occurs at approximately 13.33 feet or 160 inches. A pitch of 9 inches will be used on the girder until 13.5 feet or 162 inches from the centerline of bearing from either side. A 12 inch pitch will be used on the central region of the beam as seen in Figure 3.5. The pitch layout allows for 70 rows of studs and a total of 280 studs per girder.
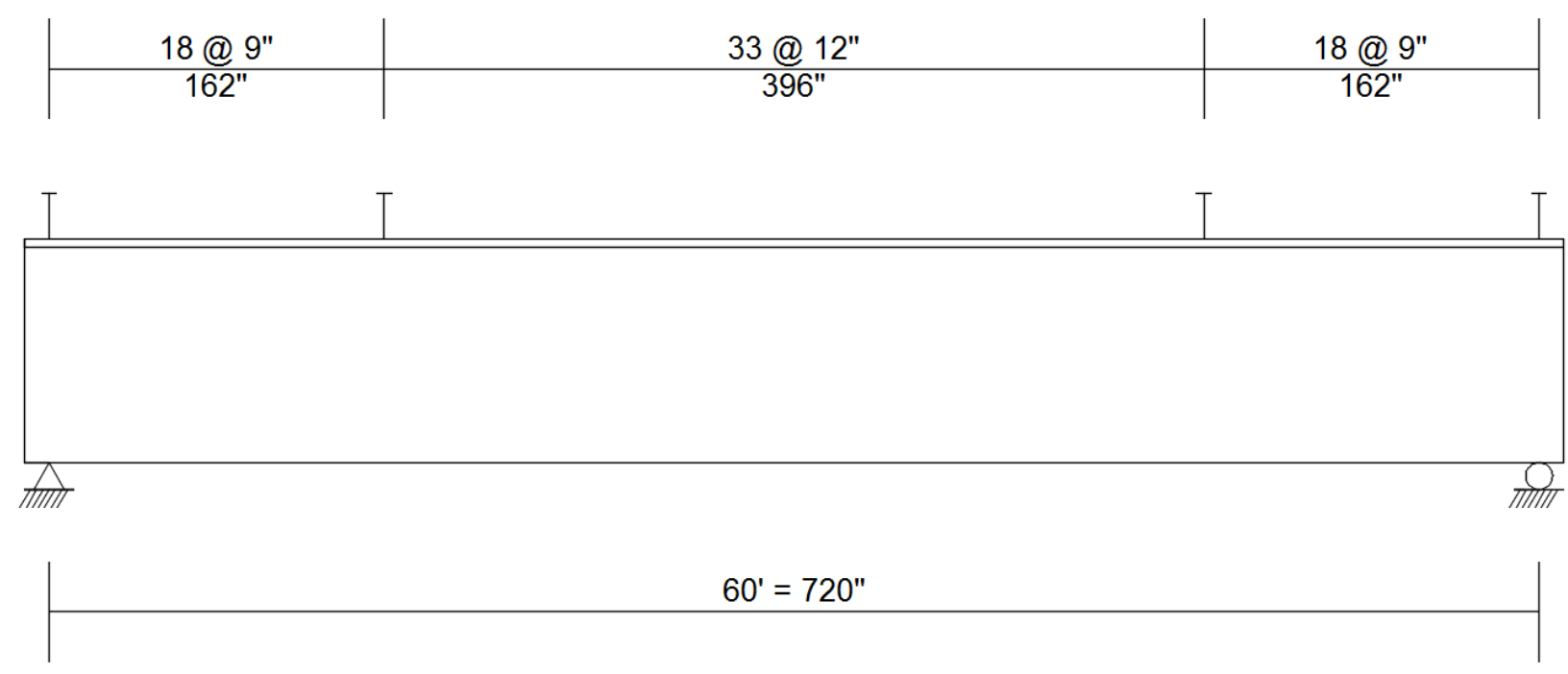

Figure 3.5: Shear Stud Spacing 


\subsection{Performance Summary}

A tabulated summary of the girder's performance ratios is presented in Table 3.18. As shown, the girder performs satisfactorily under all evaluated design checks, with the permanent deformation at the service limit state governing (Ratio $=0.776)$.

Table 3.18: Performance Ratio Summary

\begin{tabular}{lc} 
Service Limit State & \\
\hline Elastic Deformations & 0.650 \\
Permanent Deformations & \\
Top Flange & 0.398 \\
Bottom Flange & 0.776
\end{tabular}

$\underline{\text { Fatigue Limit State }}$

Bends in Plate Steel

Top Flange $\quad 0.019$

Bottom Flange $\quad 0.593$

$\underline{\text { Strength Limit State }}$

Moment 0.628

Shear 0.522

Ductility 0.463

\subsection{AASHTO EQUATION REFERENCES}

Table 3.19 details a summary of the equations referenced in the chapter along with their respective AASHTO equation and page numbers. 
Table 3.19: Equation Legend (AASHTO, 2014)

\begin{tabular}{ccc} 
Chapter 3 & AASHTO 7th Edition & $\begin{array}{c}\text { AASHTO 7th } \\
\text { Edition Page } \\
\text { Number }\end{array}$ \\
\hline Equation 3.1 & Table 4.6.2.2.2b-1 & $4-37$ \\
Equation 3.3 & Article 2.5.2.6.2 & $2-11$ \\
Equation 3.4 & Equation 6.11.2.1.2-1 & $6-179$ \\
Equation 3.5 & Equation 6.11.2.2-1 & $6-180$ \\
Equation 3.6 & Equation 6.11.2.2-2 & $6-180$ \\
Equation 3.7 & Equation 6.10.4.2.2-1 & $6-130$ \\
Equation 3.8 & Equaiton 6.10.4.2.2-2 & $6-130$ \\
Equation 3.11 & Equation 6.6.1.2.2-1 & $6-34$ \\
Equation 3.12 & Equation 6.6.1.2.5-1 & $6-48$ \\
Equation 3.13 & Equaiton 6.6.1.2.5-2 & $6-48$ \\
Equation 3.14 & Equation 6.6.1.2.5-3 & $6-48$ \\
Equation 3.16 & Equation 3.6.1.4.2-1 & $3-31$ \\
Equation 3.26 & Table D6.1-1 & $6-325$ \\
Equation 3.27 & Table D6.1-1 & $6-325$ \\
Equation 3.28 & Equation 6.10.6.2.2-1 & $6-135$ \\
Equation 3.29 & Equation 6.10.7.1.2-1 & $6-140$ \\
Equation 3.30 & Equation 6.10.7.1.2-2 & $6-140$ \\
Equation 3.31 & Equation 6.10.7.1.1-1 & $6-139$ \\
Equation 3.32 & Equation 6.10.9.2-2 & $6-153$ \\
Equation 3.33 & Equation 6.10.9.3.2-4 & $6-154$ \\
Equation 3.34 & Equation 6.10.9.2-1 & $6-153$ \\
Equation 3.35 & Equation 6.10.9.1-1 & $6-151$ \\
Equation 3.36 & Equation 6.10.7.3-1 & $6-143$ \\
Equation 3.37 & Equation 6.10.10.2-1 & $6-158$ \\
Equation 3.38 & Equation 6.10.10.1.2-3 & $6-156$ \\
Equation 3.39 & Equation 6.10.10.1.2-2 & $6-156$ \\
Equation 3.40 & Equation 6.10.10.1.2-1 & $6-156$ \\
\hline & & \\
\hline Figure 3.4 & Section 2.5.2.6.2 & $2-12$ \\
\hline Table 3.4 & Table 3.6.1.1.2-1 \\
\hline & & $3-20$ \\
\hline
\end{tabular}




\section{CHAPTER 4: EXPERIMENTAL TESTING}

\subsection{INTRODUCTION}

This chapter is an overview of the experimental testing completed to assess the fatigue performance of uncoated versus galvanized steel. A brief description of each specimen consisting of a steel-brake-formed tub girder with a reinforced concrete deck is provided herein. An instrumentation plan of the strain gages and linear variable displacement transducers (LVDTs) and a determination of load applied is provided.

\subsection{OVerview of Testing Program}

To verify the fatigue performance of modular tub girders, testing was performed at the Major Units Laboratory at West Virginia University. Fatigue testing conducted on two simply supported composite press-brake-formed tub girder specimens occurred in three-point bending as shown in Figures 4.1 and 4.2.

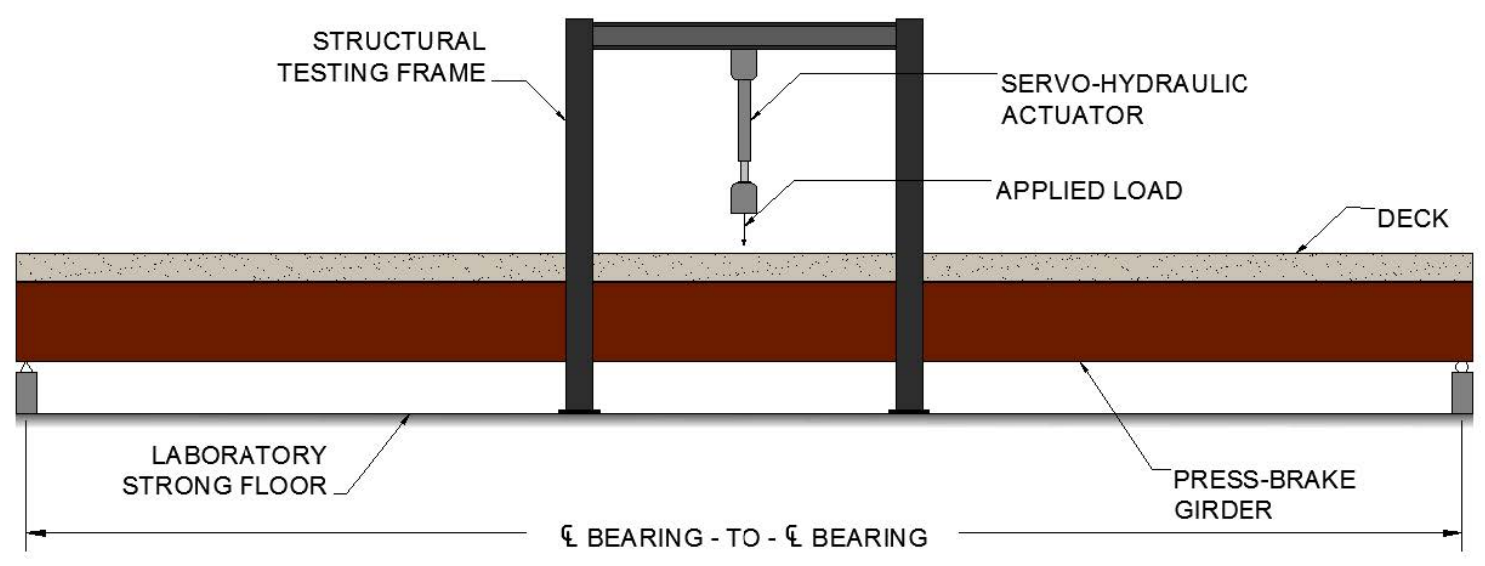

Figure 4.1: Test Setup Schematic 


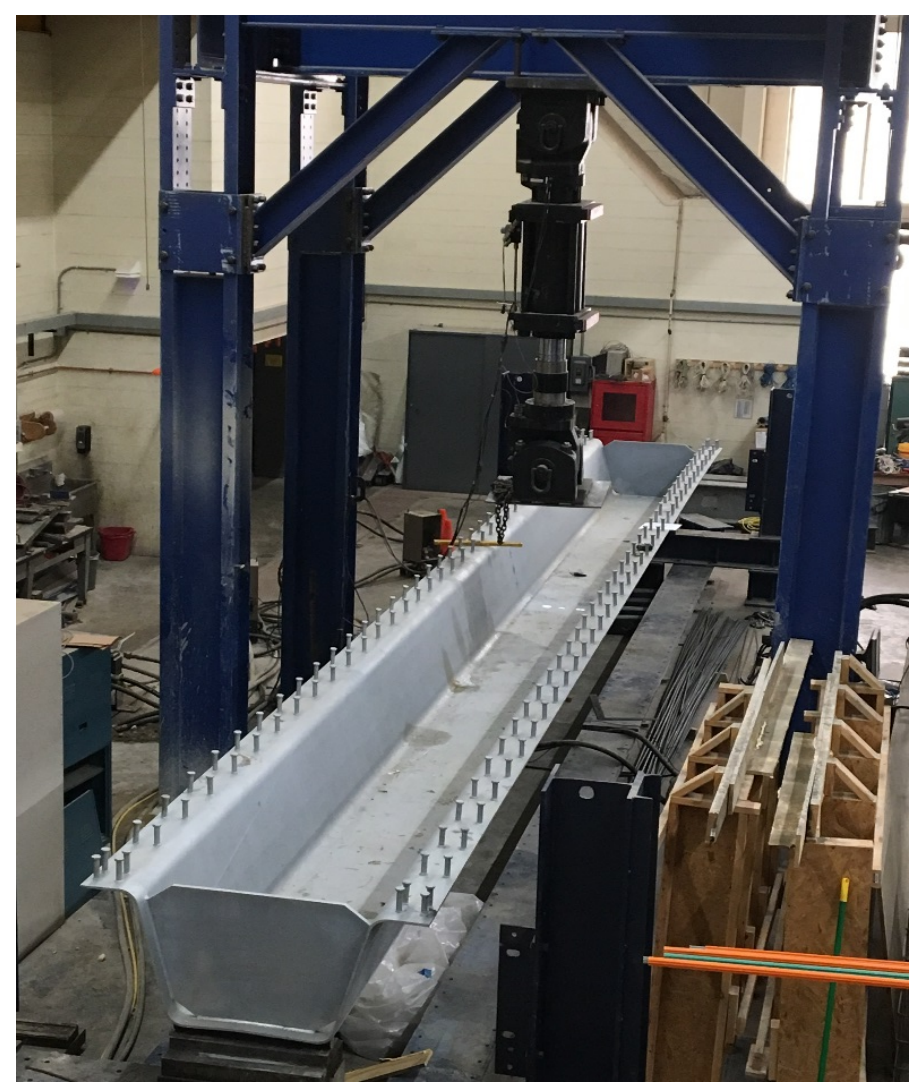

Figure 4.2: Isometric View of Typical Test Setup

Two-inch round diameter bars located under bearing plates, placed 37.5 feet between centerline of bearing to center line of bearing, simulated simply supported boundary conditions. One of the round bars was welded to the plate underneath, simulating a pinned boundary condition (Figure 4.3), and the other round bar was placed in a small groove allowing horizontal displacement, simulating a roller boundary condition (Figure 4.4). The two-inch diameter bars were supported by 6 inch x 24 inch x 2 inch plate steel, which were in turn supported by 12 inch x 24 inch x 2 inch plate steel. Four threaded rods connected the 12 inch x 24 inch x 2 inch plate, through two 6 inch x 6 inch hollow structural sections filled with concrete, to the support system shown in Figure 4.5. Lateral bracing at the support locations prevented unintentional rotation using equal leg angles connecting the specimen to the lateral-resisting steel frame. $1 / 2$ inch thick steel plate welded to the tub girder operated as connection plates for the lateral bracing elements. Figure 4.5 shows a complete setup of the lateral resisting system. 


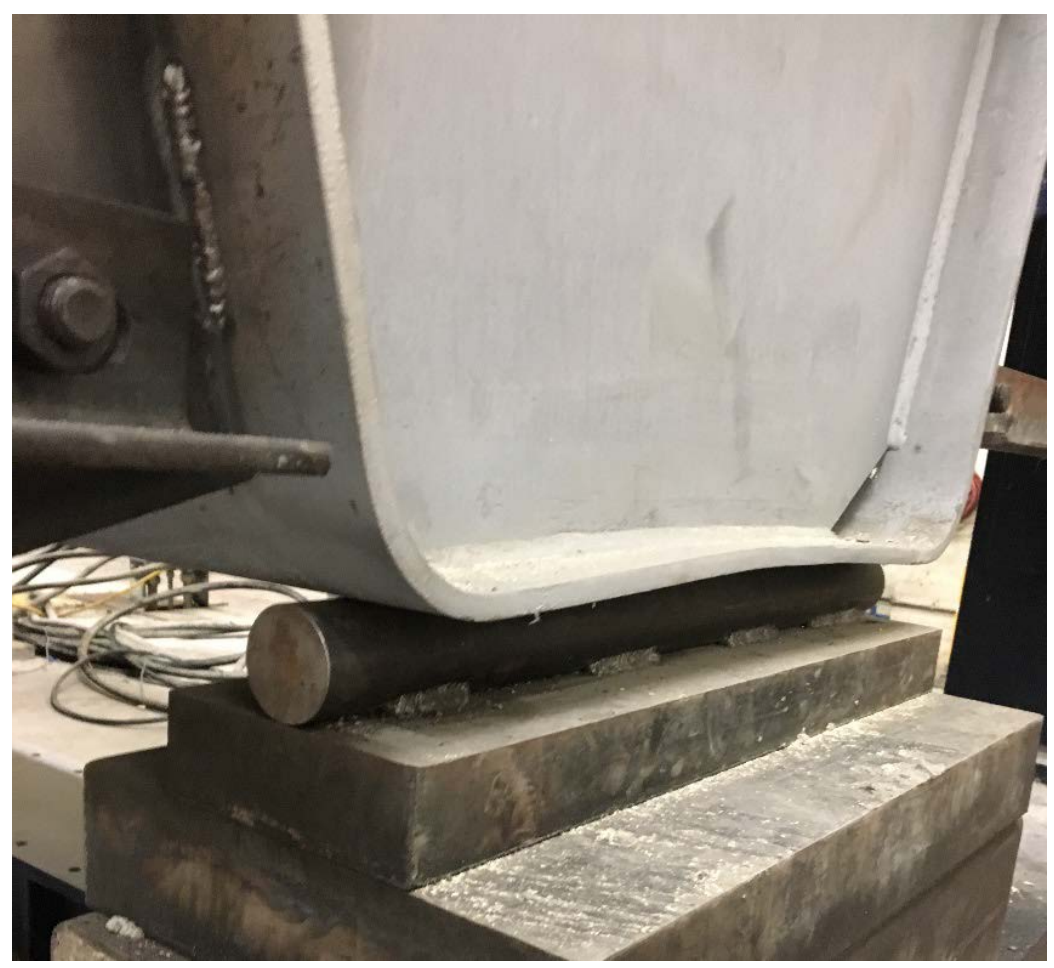

Figure 4.3: View of Pinned Boundary Condition

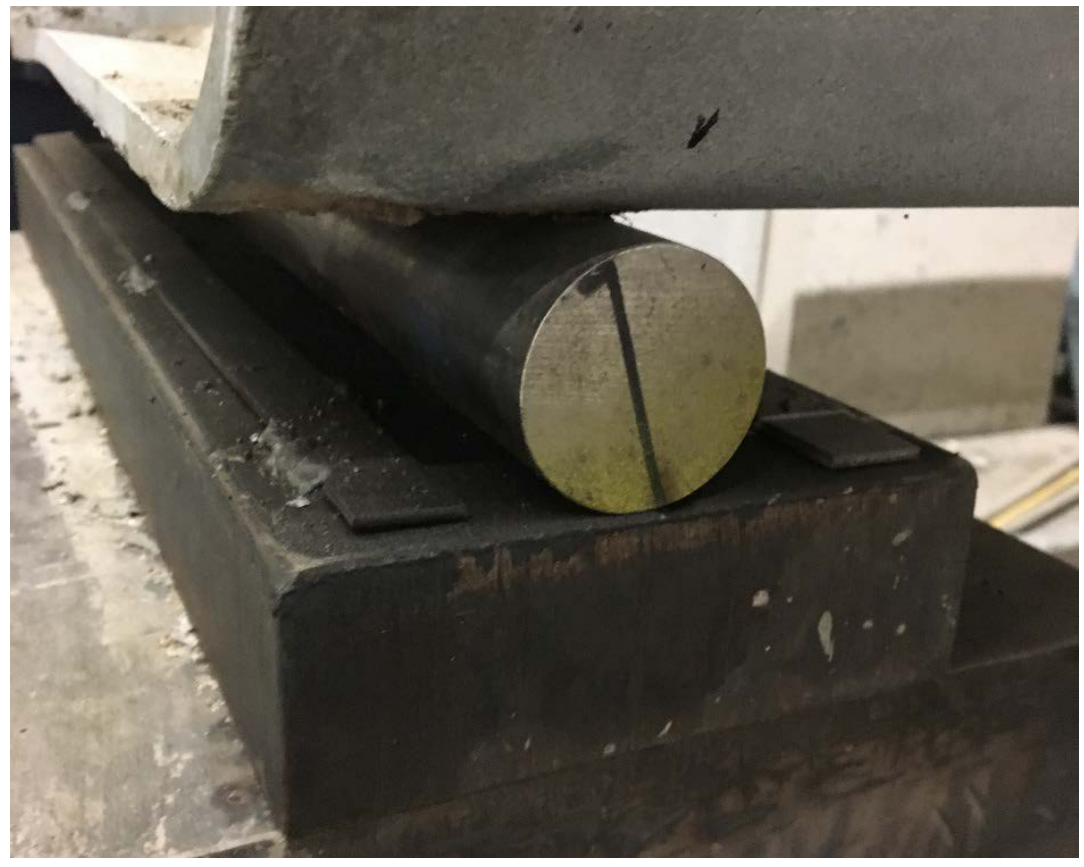

Figure 4.4: View of Roller Boundary Condition 


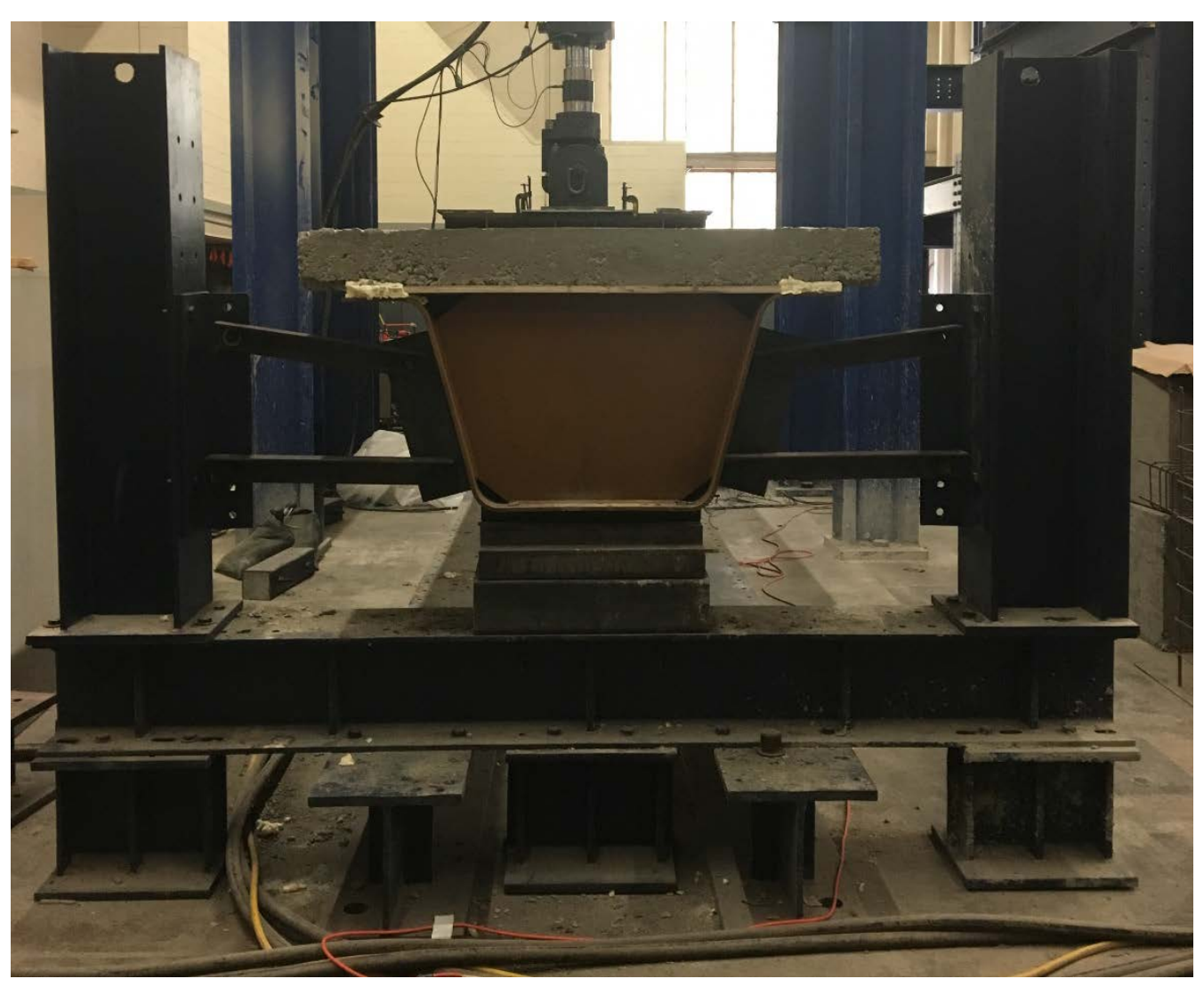

Figure 4.5: Lateral Bracing System

\subsection{SPECIMEN DESCRIPTIONS}

Michaelson (2014) found the optimum cross-section of an 84 inch x 7/16 inch plate for this press-brake-formed tub girder to have a 23 inch depth and a 6 inch top flange width. The girder was bent by being placed in a large capacity press-brake and cold-bent with the inside bend radius equal to five times the thickness of the plate. After the plate was bent into the shape (Figure 4.6), two rows of 7/8 inch by 4 inch shear studs were welded onto each 6 inch wide top flange. 3/4 inch bearing plates were then welded three inches from the end of the tub girder to prevent potential premature buckling during testing, as seen in Figures 4.7 and 4.8. Table 4.1 shows the noncomposite section properties of the 84 inch x 7/16 inch press-brake-formed tub girder (Kozhokin 2016). One specimen consisted of uncoated HPS-50 steel and the other consisted of HPS-50 steel hot dip galvanized prior to its arrival at the laboratory. 


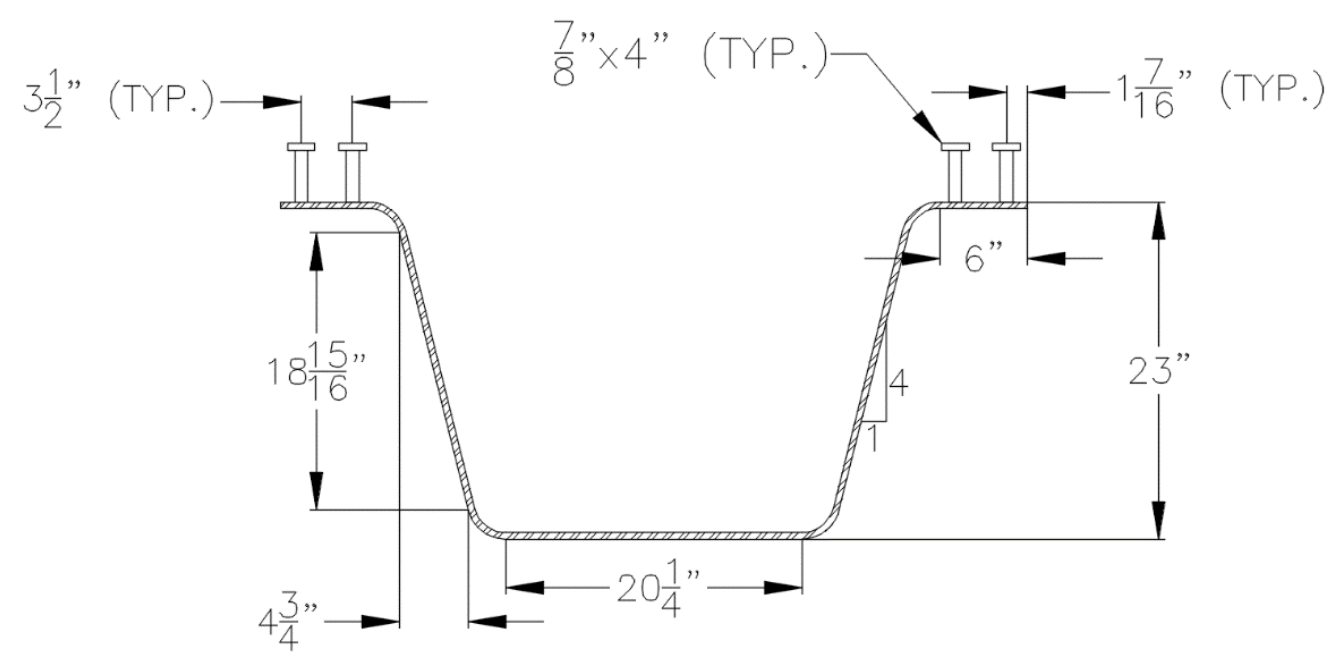

Figure 4.6: Press-Brake Tub Girder Cross Section

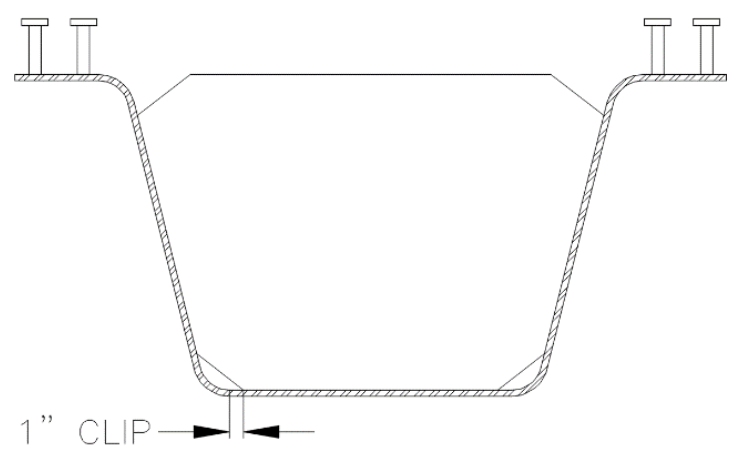

Figure 4.7: Press-Brake Tub Girder with End Diaphragm

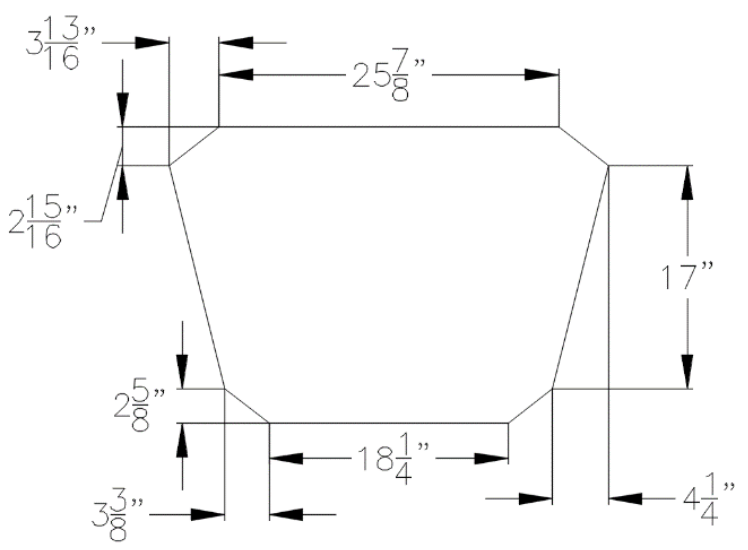

Figure 4.8: End Diaphragm 
Table 4.1: Press-Brake-Formed Tub Girder Non-Composite Section Properties

\begin{tabular}{|c|c|}
\hline Property & Value \\
\hline A (in $\left.{ }^{2}\right)$ & 36.75 \\
\hline $\mathrm{L}(\mathrm{in})$ & 444 \\
\hline $\mathrm{E}(\mathrm{ksi})$ & 29,000 \\
\hline $\mathrm{G}(\mathrm{ksi})$ & 11,154 \\
\hline $\mathrm{I}_{\mathrm{X}}\left(\mathrm{in}^{4}\right)$ & 2893.1 \\
\hline $\mathrm{I}_{\mathrm{y}}\left(\right.$ in $\left.^{4}\right)$ & 8049.6 \\
\hline $\mathrm{I}_{\text {open }}\left(\right.$ in $\left.^{4}\right)$ & 2.3447 \\
\hline $\mathrm{I}_{\text {closed }}\left(\mathrm{in}^{4}\right)$ & 69,000 \\
\hline $\mathrm{I}_{\mathrm{W}}\left(\mathrm{in}^{6}\right)$ & 139,952 \\
\hline$\beta_{\mathrm{X}}(\mathrm{in})$ & -19.704 \\
\hline
\end{tabular}

\subsection{INSTRUMENTATION}

\subsubsection{Instruments}

Two types of bondable foil strain gages measured the strain in the tub girder: uniaxial linear pattern on the bottom flange and rectangular rosettes on the webs. The uniaxial strain gages recorded strain in one direction while the rectangular rosettes recorded axial strain and shear at each gage location. LVDTs measured the vertical deflections at various locations. The strain gages and LVDTs connected to a Micro-Measurements Model 5100 Scanner, which in turn utilized StrainSmart software (Micro-Measurements, 2010) to record the strain and displacement data. An MTS Model 201.70 330-kip servo hydraulic actuator applied the load to the system.

\subsubsection{Layout of Strain Gages}

Six uniaxial strain gages, placed along the top and bottom of the bottom flange of the tub girder measured the extreme tensile stresses in the system. Twelve rectangular rosettes, placed along the interior and exterior of the webs, captured the bending and shear strains. The eighteen strain gages employed during testing are shown in Figure 4.9. The gages were placed at 46 inches, 
twice the girder depth, away from the load application to avoid strain concentration effects of the load. The nine strain gages on the interior face of the girder can be seen in Figure 4.10. The interior gages where then covered with two inch insulation board for protection during the concrete pour (Figure 4.11). The exterior gages were covered in a roll of plastic for protection from regular laboratory operations.

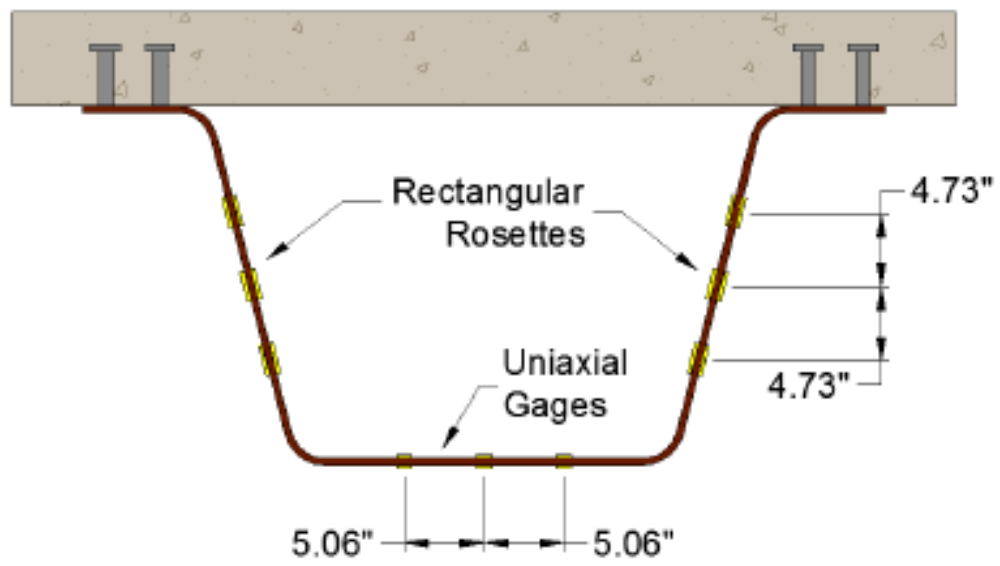

Figure 4.9: Strain Gage Layout

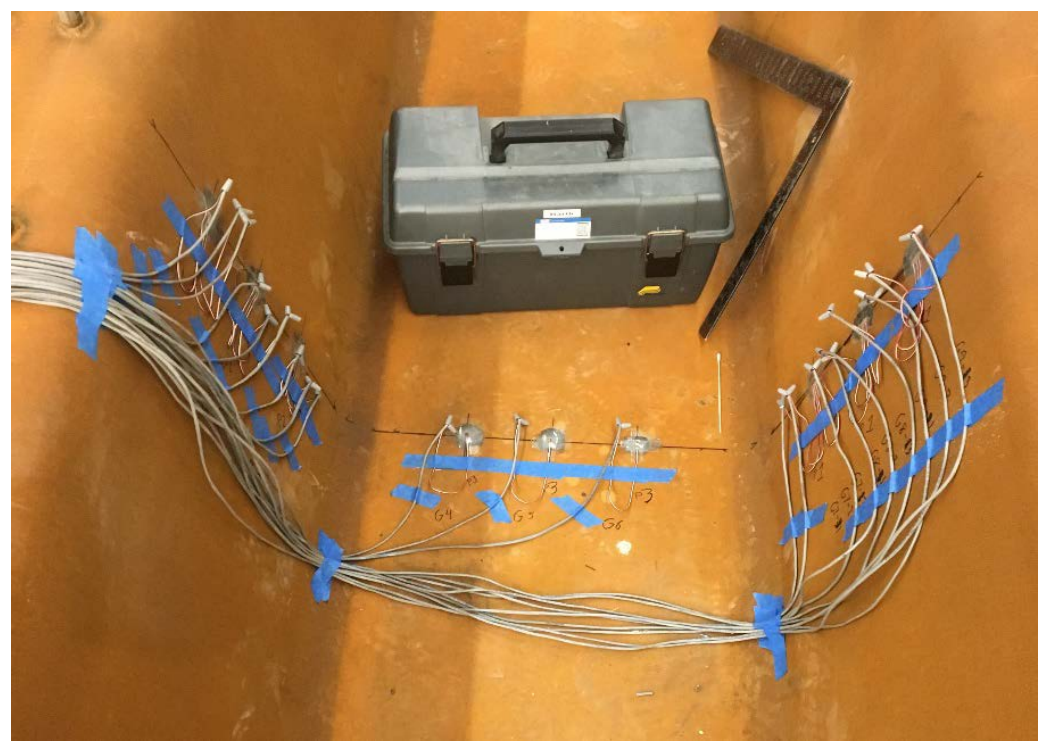

Figure 4.10: Exposed Strain Gages 


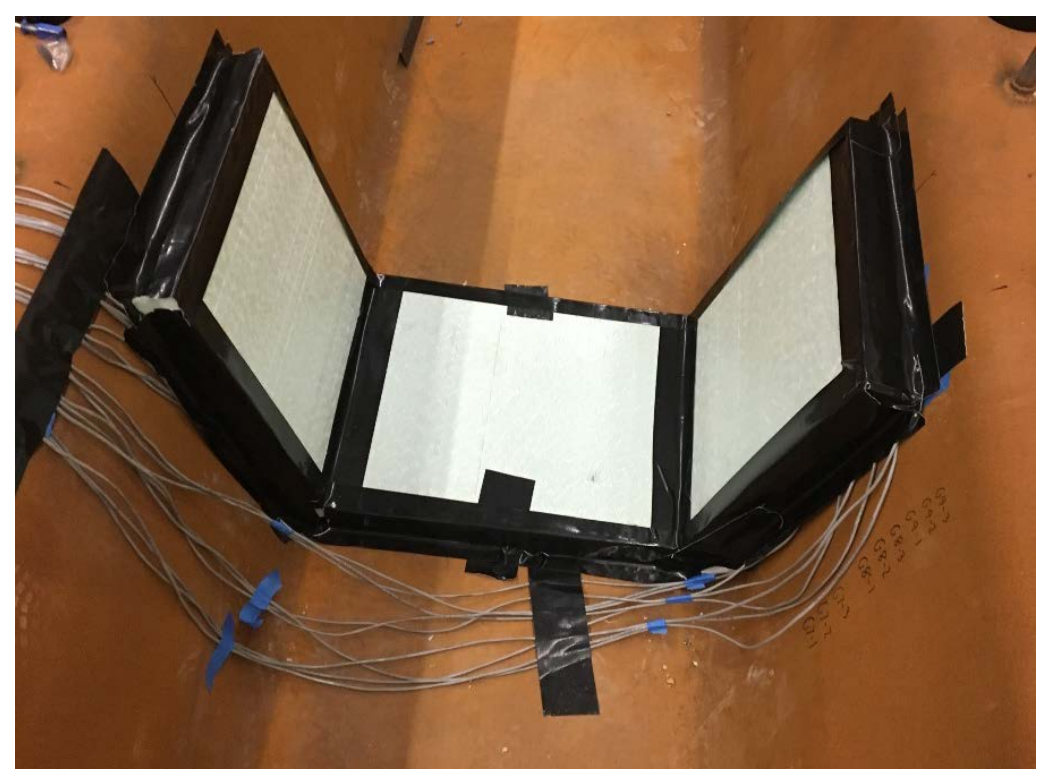

Figure 4.11: Covered Strain Gages

\subsubsection{Layout of LVDTs}

Three LVDTs along the length of the girder measured vertical deflections. One LVDT was located at mid-span and the other two were placed at quarter points on the girder. These LVDTs were placed in the center of the bottom flange. By placing the LVDTs under the bottom flange, consideration of torsional deflections from the flanges were neglected.

\subsection{Test Specimen AsSEmbly}

\subsubsection{Concrete Formwork}

Concrete formwork was placed in and around the 38 foot long tub girders. 2 inch $\mathrm{x} 4$ inch dimensional lumber was cut to fit inside the girders to support the stay in place plywood (Figure 4.12). Expanding spray foam sealed locations not completely enclosed by the frame work, such as where the wires connecting the interior strain gages entered the tub girder. During construction for industry, the plywood forms would be replaced with SIP metal formwork. 


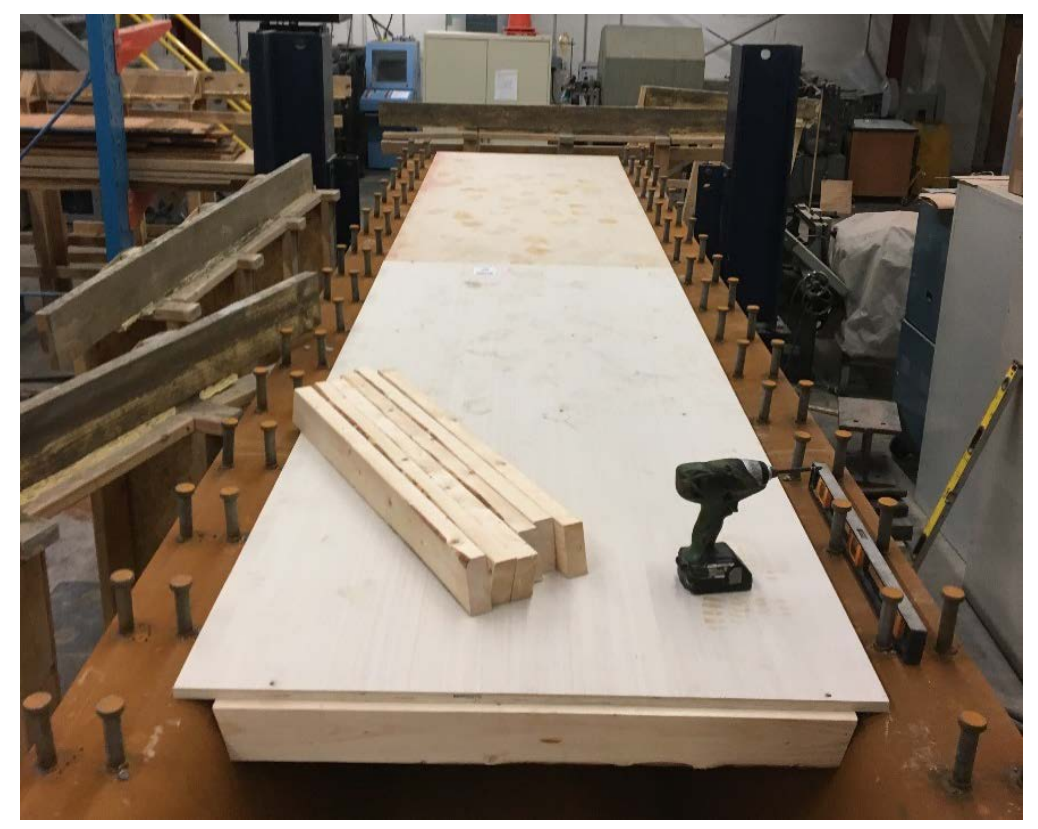

Figure 4.12: Supports Inside the Girder

Most exterior forms were reused from previous testing performed by Michaelson (2014) and Kozhokin (2016), but their specimens were 35 feet long where the specimens tested for this study were 38 feet long. This difference necessitated additional framework construction. 2 inch $\mathrm{x}$ 8 inch lumber was cut to produce a 6 inch deep concrete deck and was placed around the top of the formwork. The forms allowed a 4.5 inch overhang on either side of the steel tub girder for the concrete deck. The formwork was braced using large concrete blocks as dead-man anchors. Repeated use of the forms created a bow in the formwork, requiring the use of additional bracing as seen in Figure 4.13 


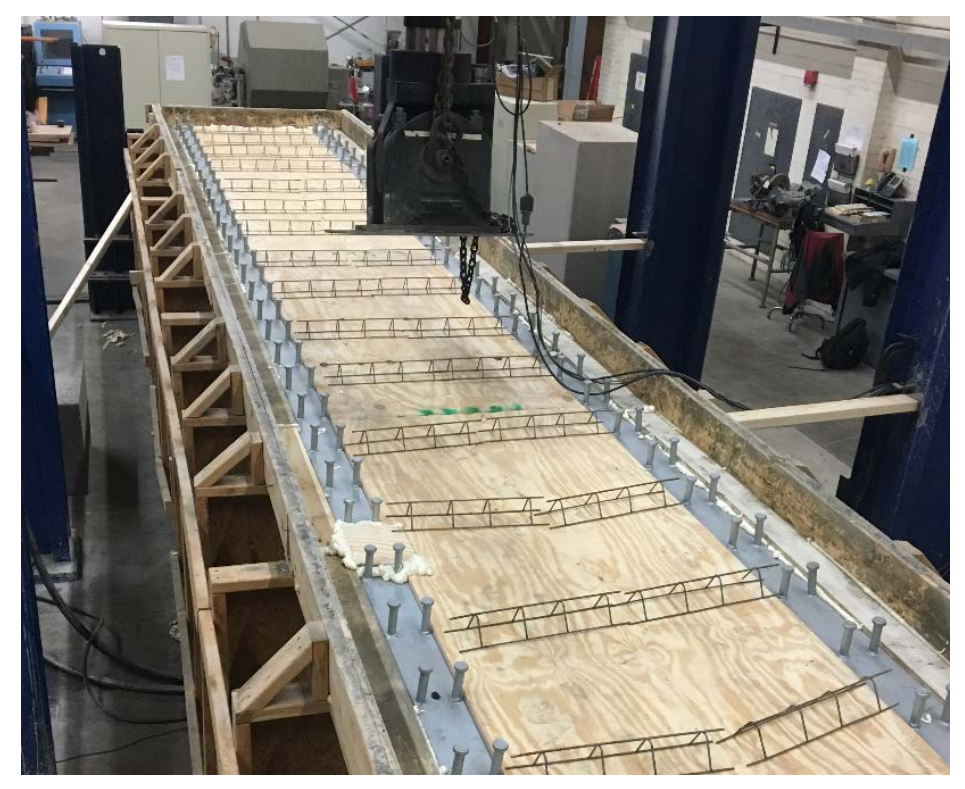

Figure 4.13: Completed Concrete Formwork

\subsubsection{Reinforcing Bars}

AASHTO Article 9.7.2 was used to design the reinforcement pattern with the empirical deck method. The bottom mat of reinforcing steel bars consisted of \#5 rebar with a bottom cover of one inch. The top mat of reinforcement consisted of \#4 rebar placed two inches above the bottom mat, creating a top cover of two inches. The longitudinal rebar of both layers was spaced at 12 inches with an edge space of two inches. The transverse bars had a spacing of 12 inches, which coincided with the placement of the shear studs and the typical edge spacing of two inches. The reinforcement pattern can be seen in Figure 4.14. 


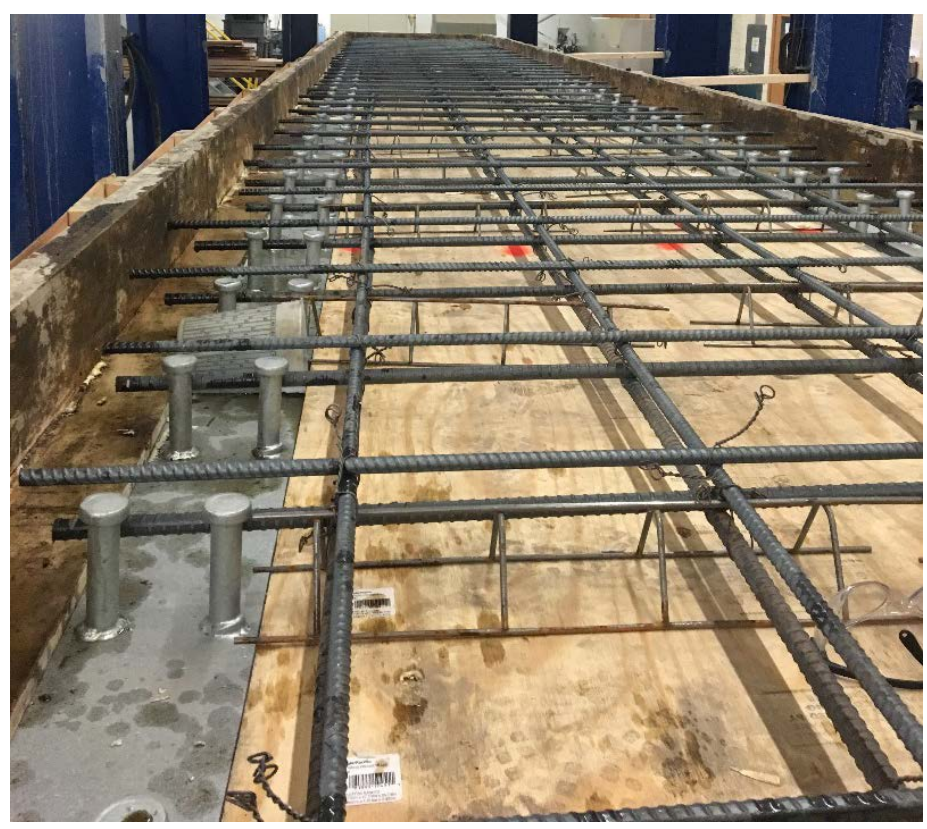

Figure 4.14: Placement of Reinforcing Steel

\subsubsection{Concrete Deck Pour}

Approximately two days prior to the concrete pour, the outer formwork was coated in form release. This allowed the easy removal of the forms for reuse in future tests without significant damage to the concrete deck. Once the concrete arrived on site, four 6 inch diameter cylinders were poured for future compressive strength testing. A one yard concrete bucket attached to an overhead ten ton crane (Figure 4.15) delivered the wet concrete from the truck to the pour location. The concrete was vibrated after each successive pour from the bucket to minimize air pockets and honey combing. 


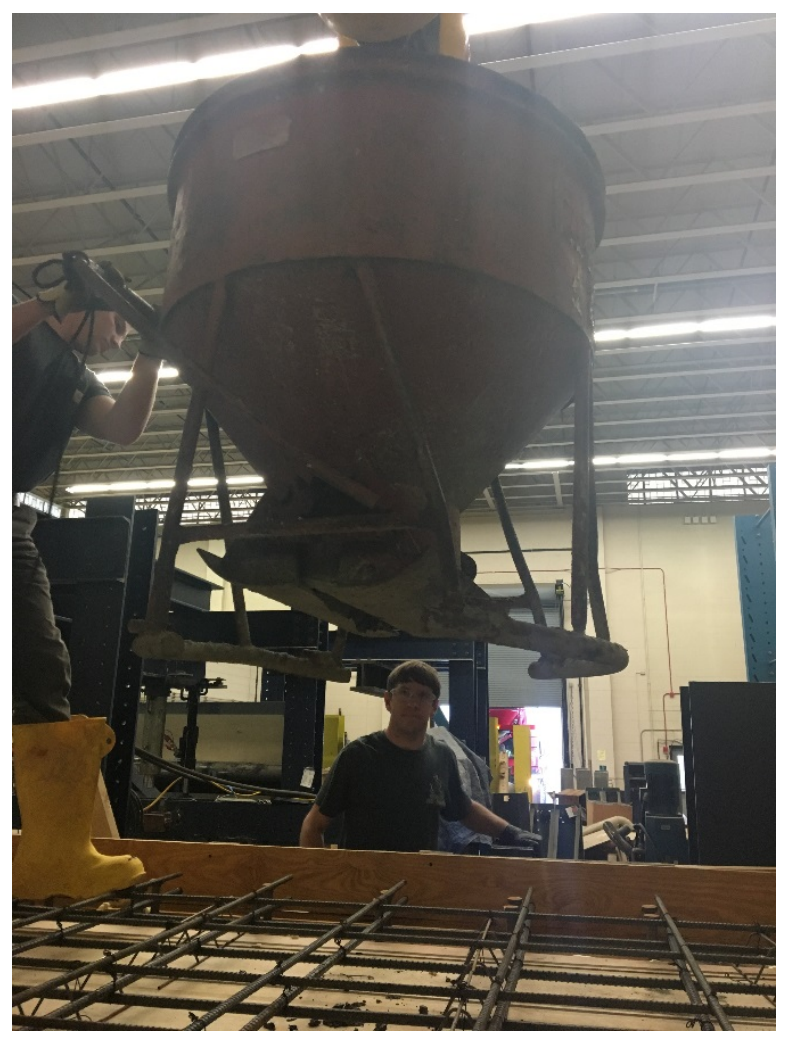

Figure 4.15: Concrete Bucket Lowering into Position

The entire pouring process lasted approximately two hours for each deck placement. The concrete cured before the formwork was stripped from the composite unit. The deck was inspected for any damage from the removal of the formwork and only minimal localized damage occurred at locations where forms were pried away from the deck. The completed concrete deck is seen in Figure 4.16. The concrete was allowed to cure for at least 28 days prior to loading. 


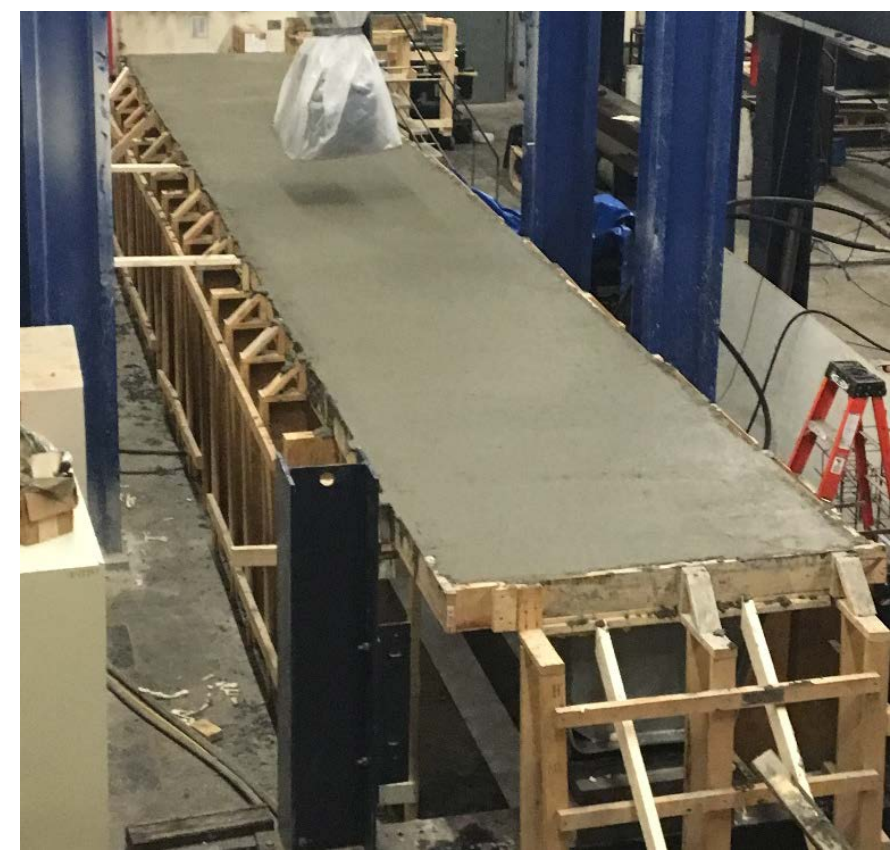

Figure 4.16: Poured Concrete Deck

\subsection{LOAD CONFIGURATION}

The induced load was applied at the mid-span of the system by an MTS 330-kip servohydraulic actuator mounted to a large steel structural frame bolted to the floor of the major unit's laboratory (Figure 4.17). A large spreader beam was attached to the head of the actuator using large C-clamps to avoid localized concrete crushing due to concentrated load effects. An elastomeric pad was placed between the spreader beam and the concrete deck, as seen in Figure 4.17. Elastomeric bearing pads consist of alternating layers of neoprene, an industrial grade rubber, and steel strips. These bearing pads aid in transfer of load from the spreader beam to the deck. 


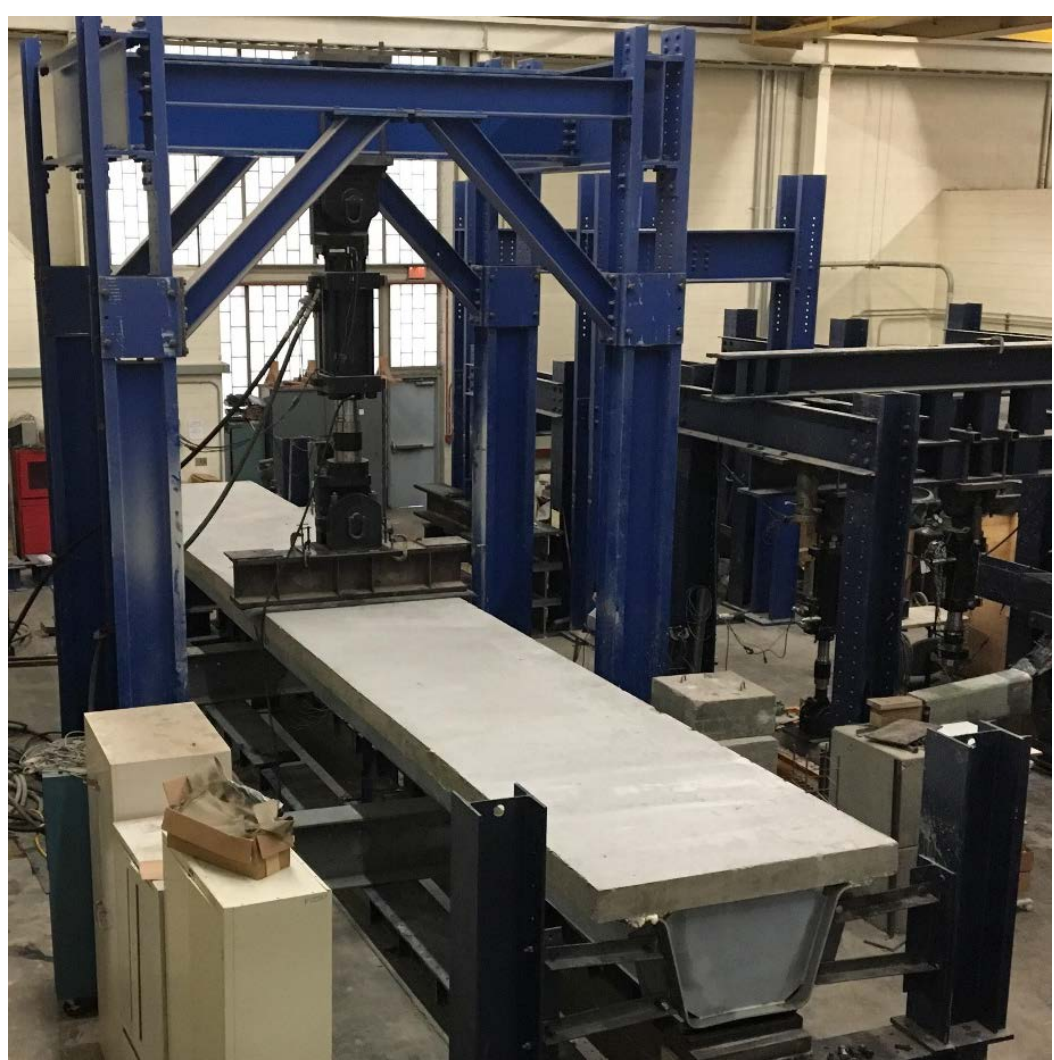

Figure 4.17: Load Applied to the System

\subsection{LOAd MAgNitude DETERMinAtion}

\subsubsection{Load Determination Overview}

The loads required to induce the Service II and Fatigue I moments needed to be calculated prior to testing of the specimen. The Service II load combination is intended to control yielding of steel structures due to vehicular live loads and is determined using AASHTO Tables 3.4.1-1 and 3.4.1-2.

Service II $=1.0 \mathrm{DC}+1.0 \mathrm{DW}+1.3(\mathrm{LL}+\mathrm{IM})$

Eq. 4.1 
The Fatigue I load combination is related to infinite load-induced fatigue life and is determined using AASHTO Tables 3.4.1-1 and 3.4.1-2.

$$
\text { Fatigue I = 1.75(LL + IM) }
$$

The terms used in AASHTO LRFD Article 3.3.2 for Equations 4.1 and 4.2 were previously defined in Section 3.4 Loads and Load Combinations.

\subsubsection{Magnitude of Applied Loads}

A static load of 92.50 kip was applied to the uncoated steel specimen to induce the Service II moment. The MTS 330-kip servo-hydraulic actuator applied a cyclic load of 68.30 kip to induce the Fatigue I moment. For the galvanized steel specimen, a static load of 93.00 kip was applied to induce the Service II moment. The actuator applied a cyclic load of 68.50 kip to induce the Fatigue I moment. Procedures outlining the calculation of these loads are described in Appendix A.

\subsubsection{Number of Cycles}

Three assumptions were made to determine the number of fatigue cycles:

1. The average daily traffic (ADT) was 800 vehicles.

2. The bridge was in a non-interstate rural environment.

3. The Design Life was 75 years

AASHTO Table C3.6.1.4.2-1 was used to determine 15\% of the ADT are trucks due to the rural non-interstate environment where the bridge is located. With two lanes available to trucks, AASHTO Table 3.6.1.4.2-1 expresses the $(A D T T)_{S L}$ is equal to $85 \%$ of the ADTT ( $\left.p=0.85\right)$. The number of fatigue cycles, assuming a 75 year design life, was determined as follows:

Number of Cycles $=800($ ADT) $\times 0.15$ (representing 15\% truck traffic) $\times 0.85(p) \times$ 365 (Days/Year) x 75 (years) $=$ 2,792,250 Cycles 


\subsection{Testing Procedure}

\subsubsection{Procedure for Fatigue Testing}

As discussed in Section 4.4 Instrumentation, nine strain gages were used on the interior of the tub girder and nine strain gages were used on the outside of the tub girder at a distance of 46 inches from midspan. Three LVDTs placed under the bottom flange of the girder were located at quarter points of the span to measure vertical deflections.

The fatigue loading frequency of the uncoated steel girder was kept constant at 0.5 hertz. The fatigue loading frequency for the galvanized steel girder initially began at 0.5 hertz, but through the cyclic loading the actuator began to no longer meet the required loading of 68.48 kip, so the frequency was slowed at 0.01 hertz increments until the load range needed to reach the Fatigue I moment was attained. Typically, the actuator needed to be slowed by 0.01 hertz after each static loading of the Service II load.

A static base test was conducted before fatigue loading began. Five LVDT and the strain gage readings were taken before any load was applied by the actuator. The load was increased in ten 9.30 kip intervals to reach the Service II loading. Every five minutes, five readings were recorded and the load was increased. The five minute wait insured the system had settled and removed any vibration effects from the previous increase in loading. The loading to 93 kip occurred twice and the readings from the strain gages and LVDTs were averaged. The static testing previously described was conducted at a predetermined number of cycles: 1e5; 2e5; 3e5; 5e5; 7e5; 9e5; 1.1e6; 1.3e6; 1.5e6; 1.7e6; 1.9e6; 2.1e6; 2.3e6; 2.5e6; 2.7e6; and 2.9e6. A thorough check of the bottom tub girder bend regions was performed after each static test. 


\subsubsection{Procedure for Test to Ultimate Failure}

Once the fatigue data was collected, a static test to failure was performed on both specimens. Each specimen was loaded in stroke control for increased safety and improved accuracy of the data. The load was increased in steps where the displacement of the actuator increased between 0.05 and 0.10 inches. Figure 4.18 shows the failure mode for a typical composite section. The specimen failed under ductility where the concrete deck was crushed.

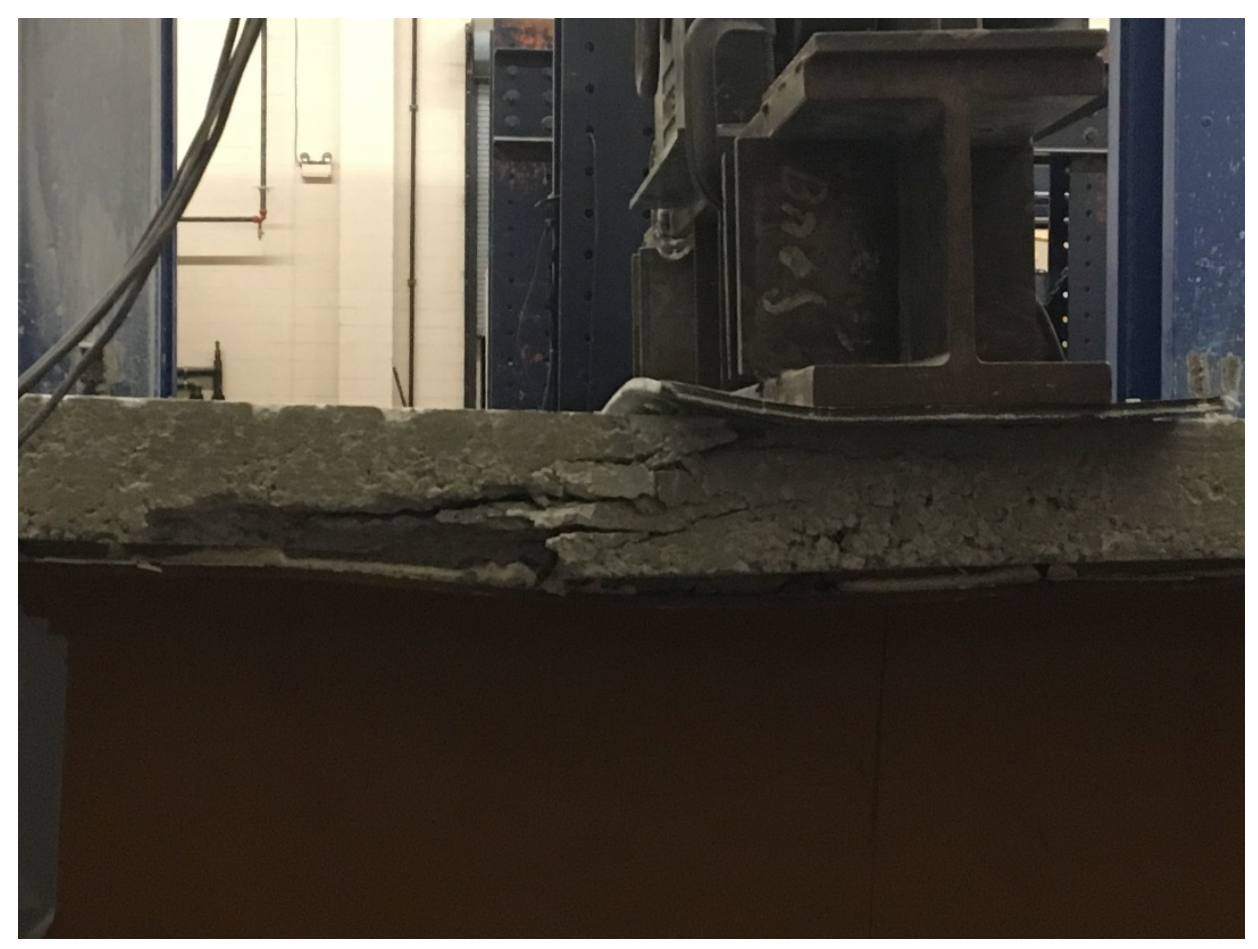

Figure 4.18: Typical Failure Mode for Composite Specimens

\subsection{SUMMARY}

This chapter described the assembly of the 38 foot modular specimens. The 38 foot specimens were simply supported under their bearing plates creating a 37.5 foot simple span. The strain gages were placed at a distance twice the depth of the steel tub girder away from the loading location. A reinforced concrete deck poured over the girder connected by shear studs created the composite modular unit. After the concrete deck cured for 28 days, fatigue loading commenced on the specimen. Strains and deflections at predetermined cycle implements were recorded. 


\section{CHAPTER 5: EXPERIMENTAL TESTING RESULTS}

\subsection{INTRODUCTION}

This chapter describes the results obtained during testing and the methods used to analyze the collected data. Results of the compressive testing of the concrete used in the concrete deck of each testing specimen are reported. A description of procedures used to calculate stresses and the moment induced by the applied load is included here. The testing summaries and comparison of experimental versus theoretical loads at each static test is provided. The deflections of each girder at the Service II loading are compared in the last section of this chapter.

\subsection{CONCRETE STRENGTH}

As noted in Chapter 4: Experimental Testing, concrete samples were tested after 28 days to calculate their compressive strength. The concrete compressive strength testing results of the deck for each test specimen are summarized in Table 5.1.

Table 5.1: Concrete Compressive Strength Results

\begin{tabular}{|c|c|}
\hline \multicolumn{2}{|c|}{ Uncoated Steel Specimen } \\
\hline Sample & Strength (psi) \\
\hline 1 & 3961 \\
\hline 2 & 3991 \\
\hline 3 & 4067 \\
\hline Average & 4006 \\
\hline
\end{tabular}

\begin{tabular}{|c|c|}
\hline \multicolumn{2}{|c|}{ Galvized Steel Specimen } \\
\hline Sample & Strength (psi) \\
\hline 1 & 2504 \\
\hline 2 & 2574 \\
\hline 3 & 2452 \\
\hline Average & 2510 \\
\hline
\end{tabular}

The concrete used for the deck of the uncoated steel girder met the desired compressive strength of 4000 psi. The concrete used in conjunction with the galvanized girder fell below the desired 4000 psi strength at 28 days. While it was crucial the compressive strength of the concrete not be significantly higher than 4000 psi to be able to ultimately fail the girder when testing concluded, the significantly weaker concrete was less than ideal. The weaker concrete led to more significant deck cracking throughout fatigue testing which was not as prevalent as in the testing 
with the uncoated steel girder. The weaker concrete altered the composite properties of the testing specimen, so higher deflections and strains are expected to be present in the experimental results. Additional concrete properties are shown in Table 5.2.

Table 5.2: Concrete Section Properties

\begin{tabular}{|c|c|}
\hline \multicolumn{2}{|c|}{ Uncoated Steel Specimen } \\
\hline Thickness (in) & 6 \\
\hline Width (in) & 60 \\
\hline $\mathrm{I}_{\text {slab }}\left(\right.$ in $\left.^{4}\right)$ & 1080 \\
\hline $\mathrm{E}_{\text {slab }}(\mathrm{ksi})$ & 3642.729 \\
\hline
\end{tabular}

\begin{tabular}{|c|c|}
\hline \multicolumn{2}{|c|}{ Galvized Steel Specimen } \\
\hline Thickness (in) & 6 \\
\hline Width (in) & 60 \\
\hline $\mathrm{I}_{\text {slab }}\left(\right.$ in $\left.^{4}\right)$ & 1080 \\
\hline $\mathrm{E}_{\text {slab }}(\mathrm{ksi})$ & 2883.422 \\
\hline
\end{tabular}

\subsection{Moment Calculation}

\subsubsection{Gage Configuration}

The stresses in the system were obtained from the strain data collected using a method adopted by Hewlig and Fan (2000). Longitudinal stresses caused by bending moments and axial stresses are linearly distributed across the cross section of the member. Only three stress readings from non-collinear points are needed to determine the distribution plane of the stresses. The distribution of the stress on the cross-section can be expressed using Equation 5.1:

$$
f(x, y)=a+b x+c y
$$

Where $\mathrm{a}, \mathrm{b}$, and c are constants and $\mathrm{x}$ and $\mathrm{y}$ are the coordinate system on the cross-section of the member. The strain gage location in terms of $\mathrm{x}$ and $\mathrm{y}$ coordinates is shown in Table 5.3 where the $\mathrm{x}$-datum is the bottom face of the bottom flange and y-datum is the short-term noncomposite section centroid. 
Table 5.3: $x, y$ Coordinates of Strain Gages

\begin{tabular}{|c|c|c|}
\hline \multicolumn{3}{|c|}{ Gauge Coordinates } \\
\hline \multirow{2}{*}{ Gauge } & \multicolumn{2}{|c|}{ From Datum } \\
\cline { 2 - 3 } & $\mathrm{x}$ (in) & $\mathrm{y}$ (in) \\
\hline G01 & -15.79 & 5.89 \\
\hline G02 & -14.61 & 1.16 \\
\hline G03 & -13.42 & -3.57 \\
\hline G04 & -5.06 & -9.96 \\
\hline G05 & 0.00 & -9.96 \\
\hline G06 & 5.06 & -9.96 \\
\hline G07 & 13.42 & -3.57 \\
\hline G08 & 14.61 & 1.16 \\
\hline G09 & 15.79 & 5.89 \\
\hline G10 & -16.21 & 5.78 \\
\hline G11 & -15.03 & 1.05 \\
\hline G12 & -13.85 & -3.68 \\
\hline G13 & -5.06 & -10.39 \\
\hline G14 & 0.00 & -10.39 \\
\hline G15 & 5.06 & -10.39 \\
\hline G16 & 13.85 & -3.68 \\
\hline G17 & 15.03 & 1.05 \\
\hline G18 & 16.21 & 5.78 \\
\hline
\end{tabular}

\subsubsection{Gage Data Selection}

After the system was statically loaded to the Service II moment twice, the strain gage and LVDT data were collected and sorted to only include consistent results, discarding any irregular data. Due to some inconsistencies, a degree of uncertainty is present in the system. Typically, a gage that performed irregularly would consistently perform irregularly, while gages that performed well consistently performed well. There were only a few instances where the data from a properly performing gage had to be discarded for inconsistency. The data inclusion matrix can be seen in Table 5.4 and 5.5, where " 0 " denotes data which was kept and " 1 " indicates data which was discarded due to inconsistency. Once a gage performed irregularly, it was not included in any further stress calculations. 
Table 5.4: Gage Inclusion Matrix for Uncoated Steel Test

\begin{tabular}{|c|c|c|c|c|c|c|c|c|c|c|c|c|c|c|c|c|c|}
\hline & \multicolumn{17}{|c|}{ Cycle Count } \\
\hline Gage & 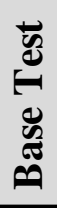 & 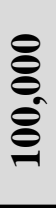 & 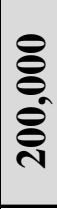 & 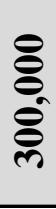 & $\begin{array}{l}\text { 8̊ } \\
\text { ᄋ̊ } \\
\text { 8̊ } \\
\text { 우 }\end{array}$ & $\begin{array}{l}8 \\
8 \\
8 \\
8 \\
8\end{array}$ & $\begin{array}{l}8 \\
8 \\
8 \\
\text { 8̊ } \\
\text { ᄋ̆ }\end{array}$ & 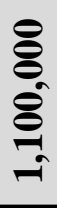 & 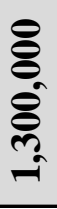 & 8ి & 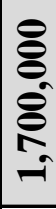 & 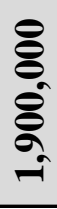 & 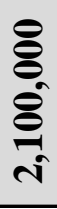 & 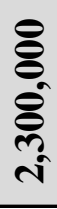 & 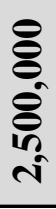 & 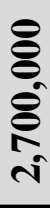 & 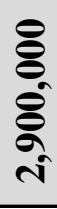 \\
\hline G01 & 1 & 1 & 1 & 1 & 1 & 1 & 1 & 1 & 1 & 1 & 1 & 1 & 1 & 1 & 1 & 1 & 1 \\
\hline G02 & 0 & 0 & 0 & 0 & 0 & 0 & 0 & 1 & 1 & 1 & 1 & 1 & 1 & 1 & 1 & 1 & 1 \\
\hline G03 & 0 & 0 & 0 & 0 & 0 & 0 & 0 & 0 & 0 & 0 & 0 & 0 & 0 & 0 & 0 & 0 & 0 \\
\hline G04 & 0 & 0 & 0 & 0 & 0 & 0 & 0 & 0 & 0 & 0 & 0 & 0 & 0 & 0 & 0 & 0 & 0 \\
\hline G05 & 0 & 0 & 0 & 0 & 0 & 0 & 0 & 0 & 0 & 0 & 0 & 0 & 0 & 0 & 0 & 0 & 0 \\
\hline G06 & 0 & 0 & 0 & 0 & 0 & 0 & 0 & 0 & 0 & 0 & 0 & 0 & 0 & 0 & 0 & 0 & 0 \\
\hline G07 & 1 & 1 & 1 & 1 & 1 & 1 & 1 & 1 & 1 & 1 & 1 & 1 & 1 & 1 & 1 & 1 & 1 \\
\hline G08 & 1 & 1 & 1 & 1 & 1 & 1 & 1 & 1 & 1 & 1 & 1 & 1 & 1 & 1 & 1 & 1 & 1 \\
\hline G09 & 1 & 1 & 1 & 1 & 1 & 1 & 1 & 1 & 1 & 1 & 1 & 1 & 1 & 1 & 1 & 1 & 1 \\
\hline G10 & 1 & 1 & 1 & 1 & 1 & 1 & 1 & 1 & 1 & 1 & 1 & 1 & 1 & 1 & 1 & 1 & 1 \\
\hline G11 & 0 & 0 & 0 & 0 & 0 & 0 & 0 & 0 & 0 & 0 & 0 & 0 & 0 & 0 & 0 & 0 & 0 \\
\hline G12 & 0 & 0 & 0 & 0 & 0 & 0 & 0 & 0 & 0 & 0 & 0 & 0 & 0 & 0 & 0 & 0 & 0 \\
\hline G13 & 0 & 0 & 0 & 0 & 0 & 0 & 0 & 0 & 0 & 0 & 0 & 0 & 0 & 0 & 0 & 0 & 0 \\
\hline G14 & 0 & 0 & 0 & 0 & 0 & 0 & 0 & 0 & 0 & 0 & 0 & 0 & 0 & 0 & 0 & 0 & 0 \\
\hline G15 & 0 & 0 & 0 & 0 & 0 & 0 & 0 & 0 & 0 & 0 & 0 & 0 & 0 & 0 & 0 & 0 & 0 \\
\hline G16 & 0 & 0 & 0 & 0 & 0 & 0 & 0 & 0 & 0 & 0 & 0 & 0 & 0 & 0 & 0 & 0 & 0 \\
\hline G17 & 0 & 0 & 0 & 0 & 0 & 0 & 0 & 0 & 0 & 0 & 0 & 0 & 0 & 0 & 1 & 1 & 1 \\
\hline G18 & 0 & 0 & 0 & 0 & 0 & 0 & 0 & 1 & 1 & 1 & 1 & 1 & 1 & 1 & 1 & 1 & 1 \\
\hline
\end{tabular}


Table 5.5: Gage Inclusion Matrix for Galvanized Steel Test

\begin{tabular}{|c|c|c|c|c|c|c|c|c|c|c|c|c|c|c|c|c|c|}
\hline & \multicolumn{17}{|c|}{ Cycle Count } \\
\hline Gage & 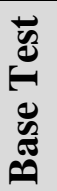 & 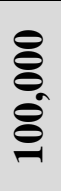 & $\begin{array}{l}\text { ठ̊ } \\
\text { ठิ } \\
\text { ¿ิ }\end{array}$ & 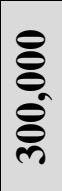 & 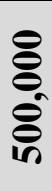 & 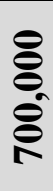 & $\begin{array}{l}\text { ठ̊. } \\
\text { \&े }\end{array}$ & 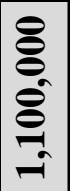 & 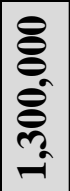 & 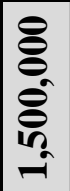 & 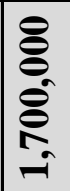 & 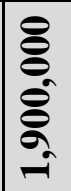 & 总 & 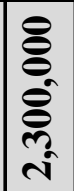 & 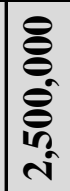 & 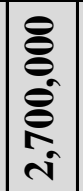 & 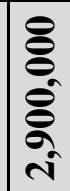 \\
\hline G01 & 1 & 1 & 1 & 1 & 1 & 1 & 1 & 1 & 1 & 1 & 1 & 1 & 1 & 1 & 1 & \begin{tabular}{|c|}
1 \\
\end{tabular} & 1 \\
\hline G02 & 0 & 0 & 0 & 0 & 0 & 0 & 0 & 0 & 0 & 0 & 0 & 0 & 0 & 1 & 1 & 1 & 1 \\
\hline G03 & 0 & 0 & 0 & 0 & 0 & 0 & 0 & 0 & 0 & 0 & 0 & 0 & 0 & 0 & 0 & 0 & 0 \\
\hline G04 & 0 & 0 & 0 & 0 & 0 & 0 & 0 & 0 & 0 & 0 & 0 & 0 & 0 & 0 & 0 & 0 & 0 \\
\hline G05 & 0 & 0 & 0 & 0 & 0 & 0 & 0 & 0 & 0 & 0 & 0 & 0 & 0 & 0 & 0 & 0 & 0 \\
\hline G06 & 0 & 0 & 0 & 0 & 0 & 0 & 0 & 0 & 0 & 0 & 0 & 0 & 0 & 0 & 0 & 0 & 0 \\
\hline G07 & 0 & 0 & 0 & 0 & 0 & 0 & 0 & 0 & 0 & 0 & 0 & 0 & 0 & 0 & 0 & 0 & 0 \\
\hline G08 & 0 & 0 & 0 & 0 & 0 & 0 & 0 & 1 & 1 & 1 & 1 & 1 & 1 & 1 & 1 & 1 & 1 \\
\hline G09 & 1 & 1 & 1 & 1 & 1 & 1 & 1 & 1 & 1 & 1 & 1 & 1 & 1 & 1 & 1 & 1 & 1 \\
\hline G10 & 1 & 1 & 1 & 1 & 1 & 1 & 1 & 1 & 1 & 1 & 1 & 1 & 1 & 1 & 1 & 1 & 1 \\
\hline G11 & 0 & 0 & 0 & 0 & 0 & 0 & 0 & 0 & 0 & 0 & 0 & 1 & 1 & 1 & 1 & 1 & 1 \\
\hline G12 & 0 & 0 & 0 & 1 & 1 & 1 & 1 & 1 & 1 & 1 & 1 & 1 & 1 & 1 & 1 & 1 & 1 \\
\hline G13 & 0 & 0 & 0 & 0 & 0 & 0 & 0 & 0 & 0 & 0 & 0 & 0 & 0 & 0 & 0 & 0 & 0 \\
\hline G14 & 0 & 0 & 0 & 0 & 0 & 0 & 0 & 0 & 0 & 0 & 0 & 0 & 0 & 1 & 1 & 1 & 1 \\
\hline G15 & 0 & 0 & 0 & 0 & 0 & 0 & 0 & 0 & 0 & 0 & 0 & 0 & 0 & 0 & 0 & 0 & 0 \\
\hline G16 & 0 & 0 & 0 & 0 & 0 & 0 & 0 & 0 & 0 & 0 & 0 & 0 & 0 & 0 & 0 & 0 & 0 \\
\hline G17 & 0 & 0 & 0 & 0 & 0 & 0 & 1 & 1 & 1 & 1 & 1 & 1 & 1 & 1 & 1 & 0 & 0 \\
\hline G18 & 0 & 1 & 1 & 1 & 1 & 1 & 1 & 1 & 1 & 1 & 1 & 1 & 1 & 1 & 1 & 1 & 1 \\
\hline
\end{tabular}

\subsubsection{Linear Regression}

To further reduce the error caused by physical measurements, due to erroneous readings, a three-dimensional linear regression algorithm was employed. The error between data points and the representative plane is at its least when using the regression method based on least square criteria. The regression method is a statistical tool and does not rely on physical assumptions. Constants $b$ and $c$ from Equation 5.1 can be solved using Equations 5.2 through 5.10. The constant $a$ can be solved using constants $b$ and $c$ in Equation 5.11. 


$$
\begin{aligned}
& {\left[\begin{array}{ll}
L_{11} & L_{12} \\
L_{21} & L_{22}
\end{array}\right]\left\{\begin{array}{l}
b \\
c
\end{array}\right\}=\left\{\begin{array}{l}
L_{10} \\
L_{20}
\end{array}\right\}} \\
& L_{11}=\sum_{i=1}^{n}\left(x_{i}-\bar{x}\right)^{2} \\
& L_{22}=\sum_{i=1}^{n}\left(y_{i}-\bar{y}\right)^{2} \\
& L_{12}=L_{21}=\sum_{i=1}^{n}\left(x_{i}-\bar{x}\right)\left(y_{i}-\bar{y}\right) \\
& L_{10}=\sum_{i=1}^{n}\left(x_{i}-\bar{x}\right)\left(f_{i}-\bar{f}\right) \\
& L_{20}=\sum_{i=1}^{n}\left(y_{i}-\bar{y}\right)\left(f_{i}-\bar{f}\right) \\
& \bar{x}=\frac{1}{n} \sum_{i=1}^{n} x_{i} \\
& \bar{y}=\frac{1}{n} \sum_{i=1}^{n} y_{i} \\
& \bar{f}=\frac{1}{n} \sum_{i=1}^{n} f_{i} \\
& a=\bar{f}-b \bar{x}-c \bar{y}
\end{aligned}
$$

\subsubsection{Calculation of Induced Moment}

The induced moments were calculated using a procedure developed from Imhoff (1998). The total moment the system carries can be broken down into three individual pieces: the steel girder bending about its own neutral axis $\left(M_{L}\right)$, concrete bending about its own neutral axis $\left(M_{u}\right)$, and the couple induced by the composite action of the deck and girder $\left(\mathrm{M}_{\mathrm{A}}\right)$ (Bertoldi 2009). Steel girder properties are summarized in Table 4.1 and concrete properties are summarized in Tables 5.1 and 5.2. These values were used in Equations 5.12 through 5.15 to calculate the total moment. 


$$
\begin{aligned}
& \mathrm{M}_{L}=\left(\sigma_{O}-\sigma_{C G}\right) S_{\text {steel }} \\
& \mathrm{M}_{u}=\left(\frac{E_{\text {slab }} I_{\text {slab }}}{E_{\text {steel }} I_{\text {steel }}}\right) M_{L} \\
& \mathrm{M}_{A}=\sigma_{C G} A_{\text {steel }}\left(d_{\text {steel }}-C G+\text { haunch }+\frac{t_{\text {slab }}}{2}\right) \\
& \mathrm{M}_{\text {total }}=M_{L}+M_{u}+M_{A} \\
& \text { Where: } \\
& S_{\text {steel }}=\text { section modulus of the steel girder } \\
& E_{\text {slab }}=\text { modulus of elasticity of concrete } \\
& I_{\text {steel }}=\text { moment of inertia of the steel girder } \\
& A_{\text {steel }}=\text { steel cross-sectional area } \\
& d_{\text {steel }}=\text { depth of steel girder section } \\
& \text { haunch = distance between the steel girder and concrete deck }
\end{aligned}
$$

The gage locations were $2 d$ (46 inches) away from midspan during testing; therefore, the moments calculated were adjusted to calculate the moments at midspan. The moment calculations for the uncoated steel specimen used centerline to centerline bearing distance of 37 feet, while the galvanized steel specimen used a centerline to centerline bearing distance of 37.5 feet. These values were used to back calculate the applied load using the equation for moment induced by a point load at midspan. The difference in distances between centerline to centerline bearing distances was due to an error in measurement of the specimens. The percent error values between the theoretical and back calculated loads at 92.5 and 93 kip are shown in Tables 5.1 and 5.2 along with the $\mathrm{R}^{2}$ values for the uncoated steel specimen and the galvanized steel specimen, respectively. 
Table 5.1: Least Squares and Percent Error for Uncoated Steel Specimen

\begin{tabular}{|r|c|c|}
\hline Cycle Count & Least Square, $\mathrm{R}^{2}$ & Percent Error, \% \\
\hline 0 & 0.9992 & 4.056 \\
\hline 100,000 & 0.9992 & 4.426 \\
\hline 200,000 & 0.9991 & 2.609 \\
\hline 300,000 & 0.9990 & 4.643 \\
\hline 500,000 & 0.9990 & 3.074 \\
\hline 700,000 & 0.9990 & 3.871 \\
\hline 900,000 & 0.9989 & 4.226 \\
\hline $1,100,000$ & 0.9989 & 3.988 \\
\hline $1,300,000$ & 0.9985 & 1.530 \\
\hline $1,500,000$ & 0.9988 & 7.052 \\
\hline $1,700,000$ & 0.9989 & 3.781 \\
\hline $1,900,000$ & 0.9986 & 2.524 \\
\hline $2,100,000$ & 0.9984 & 1.630 \\
\hline $2,300,000$ & 0.9988 & 3.688 \\
\hline $2,500,000$ & 0.9987 & -0.839 \\
\hline $2,700,000$ & 0.9982 & 0.770 \\
\hline $2,900,000$ & 0.9988 & 3.377 \\
\hline
\end{tabular}




\section{Table 5.2: Least Squares and Percent Error for Galvanized Steel Specimen}

\begin{tabular}{|r|c|c|}
\hline Cycle Count & Least Square, $\mathrm{R}^{2}$ & Percent Error, \% \\
\hline 0 & 0.9988 & 7.124 \\
\hline 100,000 & 0.9989 & 7.301 \\
\hline 200,000 & 0.9988 & 6.487 \\
\hline 300,000 & 0.9986 & 4.952 \\
\hline 500,000 & 0.9985 & 5.417 \\
\hline 700,000 & 0.9987 & 6.895 \\
\hline 900,000 & 0.9987 & 7.256 \\
\hline $1,100,000$ & 0.9986 & 7.161 \\
\hline $1,300,000$ & 0.9986 & 6.176 \\
\hline $1,500,000$ & 0.9988 & 6.323 \\
\hline $1,700,000$ & 0.9987 & 5.872 \\
\hline $1,900,000$ & 0.9987 & 6.260 \\
\hline $2,100,000$ & 0.9987 & 5.601 \\
\hline $2,300,000$ & 0.9989 & 5.105 \\
\hline $2,500,000$ & 0.9987 & 6.471 \\
\hline $2,700,000$ & 0.9989 & 5.645 \\
\hline $2,900,000$ & 0.9984 & 6.011 \\
\hline
\end{tabular}

Tables 5.3 through 5.19 summarize the moments induced into the uncoated steel specimen during each static test. In addition, Figures 5.1 through 5.17 show the plots of the theoretical load versus the experimentally calculated values. Tables 5.20 through 5.36 and Figures 5.18 through 5.34 summarize the same information for the galvanized steel specimen. Figures 5.1 through 5.36 show the theoretical load applied and the actual load induced in the system are very close and linear in nature. The theoretical load is the load the actuator applied into the entire structural system, including the girder and frame. The experimental loads are calculated using strains obtained in the tub girder systems. A small portion of the load deflected the structural frame, which explains the discrepancies between the experimental and theoretical loads. 
Table 5.3: Load Test Summary at 0 Cycles

\begin{tabular}{|c|c|c|c|}
\hline \multicolumn{4}{|c|}{ Load Test Summary (N=0) } \\
$\begin{array}{c}\text { Applied } \\
\text { Load, P (kip) }\end{array}$ & $\begin{array}{c}\text { Moment @ } \\
\text { Gage Loc. (ft-kip) }\end{array}$ & $\begin{array}{c}\text { Moment @ } \\
\text { Midspan (ft-kip) }\end{array}$ & $\begin{array}{c}\text { Back-Calc. } \\
\text { Appl. Load (kip) }\end{array}$ \\
\hline 0 & 0 & 0 & 0 \\
\hline 9.25 & 85.15 & 107.41 & 11.61 \\
\hline 18.50 & 148.72 & 187.59 & 20.28 \\
\hline 27.75 & 211.03 & 266.18 & 28.78 \\
\hline 37.00 & 273.46 & 344.93 & 37.29 \\
\hline 46.25 & 336.16 & 424.01 & 45.84 \\
\hline 55.50 & 398.49 & 502.64 & 54.34 \\
\hline 64.75 & 460.94 & 581.41 & 62.86 \\
\hline 74.00 & 523.88 & 660.80 & 71.44 \\
\hline 83.25 & 586.44 & 739.72 & 79.97 \\
\hline 92.50 & 650.82 & 820.92 & 88.75 \\
\hline
\end{tabular}

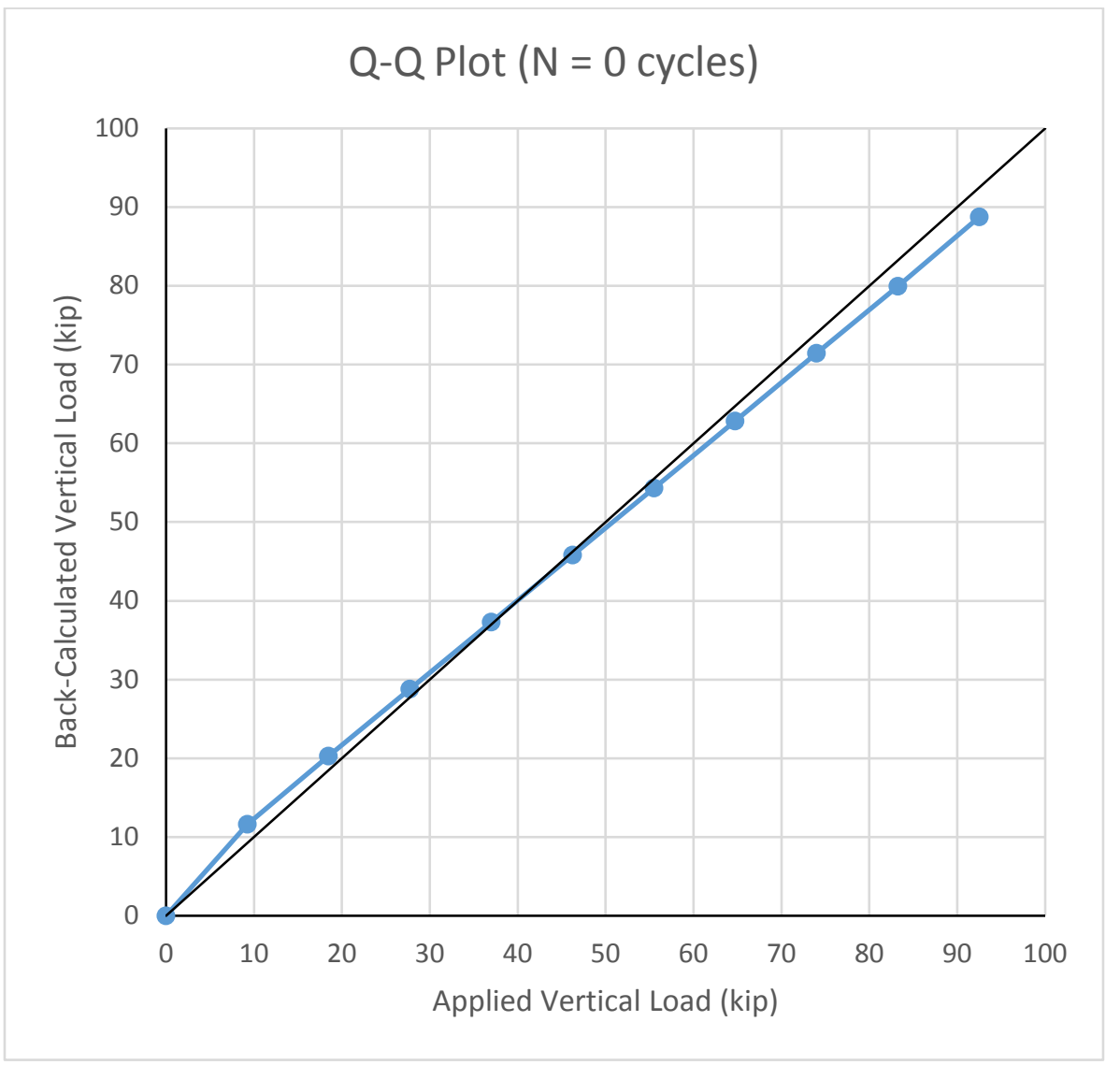

Figure 5.1: Experimental vs. Theoretical Loads at 0 Cycles 
Table 5.4: Load Test Summary at 100,000 Cycles

\begin{tabular}{|c|c|c|c|}
\hline $\begin{array}{c}|c| \\
\text { Load Test Summary (N=100,000) } \\
\text { Load, P (kip) }\end{array}$ & $\begin{array}{c}\text { Moment @ } \\
\text { Gage Loc. (ft-kip) }\end{array}$ & $\begin{array}{c}\text { Moment @ } \\
\text { Midspan (ft-kip) }\end{array}$ & $\begin{array}{c}\text { Back-Calc. } \\
\text { Appl. Load (kip) }\end{array}$ \\
\hline 0 & 0 & 0 & 0 \\
\hline 9.25 & 84.65 & 106.77 & 11.54 \\
\hline 18.50 & 147.93 & 186.60 & 20.17 \\
\hline 27.75 & 210.77 & 265.86 & 28.74 \\
\hline 37.00 & 273.41 & 344.87 & 37.28 \\
\hline 46.25 & 335.71 & 423.45 & 45.78 \\
\hline 55.50 & 398.04 & 502.07 & 54.28 \\
\hline 64.75 & 460.80 & 581.24 & 62.84 \\
\hline 74.00 & 522.75 & 659.38 & 71.28 \\
\hline 83.25 & 585.27 & 738.23 & 79.81 \\
\hline 92.50 & 648.31 & 817.76 & 88.41 \\
\hline
\end{tabular}

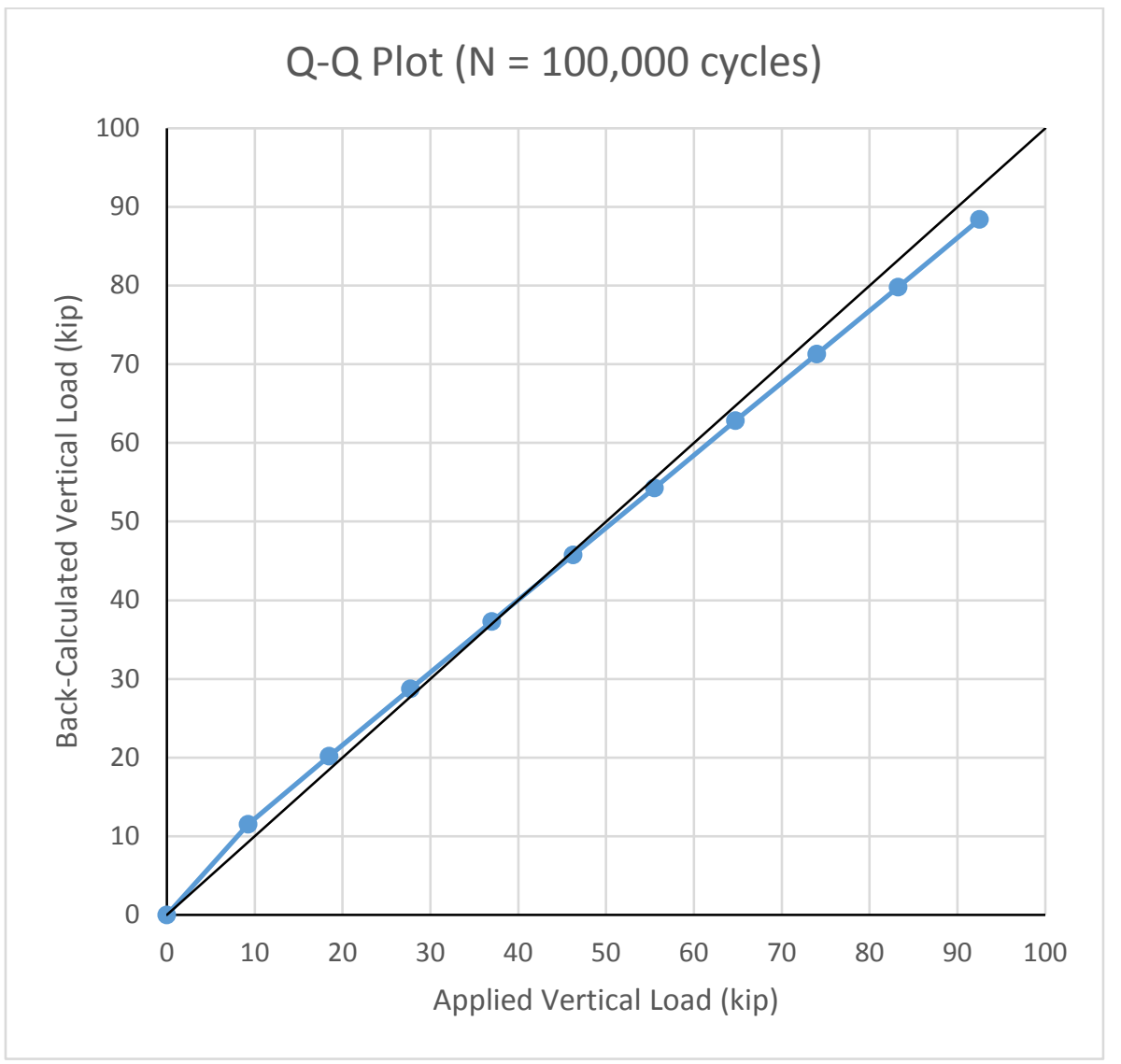

Figure 5.2: Experimental vs. Theoretical Loads at 100,000 Cycles 


\section{Table 5.5: Load Test Summary at 200,000 Cycles}

\begin{tabular}{|c|c|c|c|}
\hline $\begin{array}{c}\text { Load Test Summary (N=200,000) } \\
\text { Aoad, P (kip) }\end{array}$ & $\begin{array}{c}\text { Moment @ } \\
\text { Gage Loc. (ft-kip) }\end{array}$ & $\begin{array}{c}\text { Moment @ } \\
\text { Midspan (ft-kip) }\end{array}$ & $\begin{array}{c}\text { Back-Calc. } \\
\text { Appl. Load (kip) }\end{array}$ \\
\hline 0 & 0 & 0 & 0 \\
\hline 9.25 & 88.04 & 111.05 & 12.01 \\
\hline 18.50 & 151.81 & 191.48 & 20.70 \\
\hline 27.75 & 214.97 & 271.15 & 29.31 \\
\hline 37.00 & 278.98 & 351.89 & 38.04 \\
\hline 46.25 & 344.18 & 434.14 & 46.93 \\
\hline 55.50 & 407.67 & 514.22 & 55.59 \\
\hline 64.75 & 470.81 & 593.86 & 64.20 \\
\hline 74.00 & 534.18 & 673.80 & 72.84 \\
\hline 83.25 & 597.24 & 753.34 & 81.44 \\
\hline 92.50 & 660.63 & 833.30 & 90.09 \\
\hline
\end{tabular}

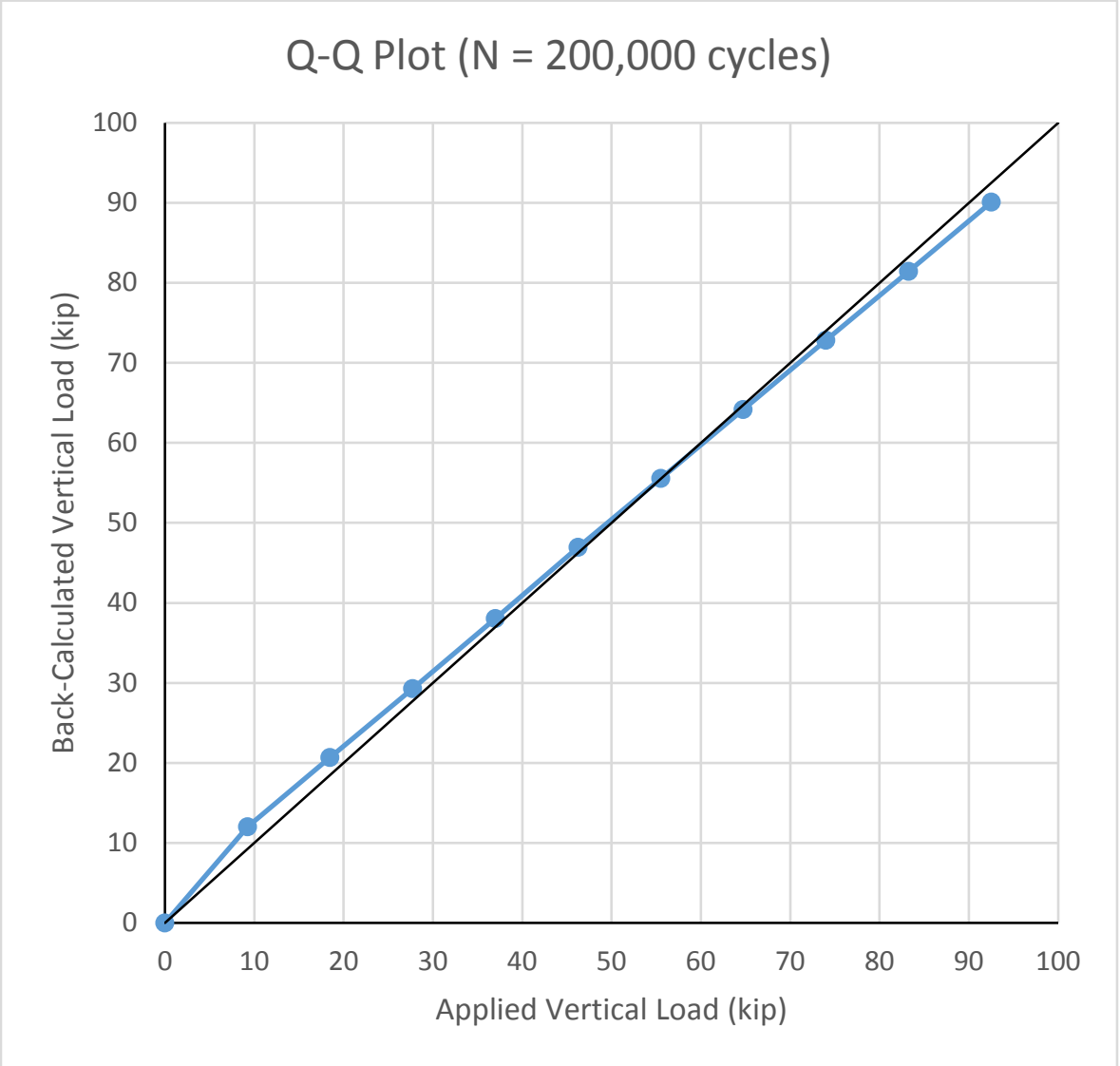

Figure 5.3: Experimental vs. Theoretical Loads at 200,000 Cycles 
Table 5.6: Load Test Summary at 300,000 Cycles

\begin{tabular}{|c|c|c|c|}
\hline $\begin{array}{c}|c| \\
\text { Applied } \\
\text { Load, P (kip) }\end{array}$ & $\begin{array}{c}\text { Moment @ } \\
\text { Gage Loc. (ft-kip) }\end{array}$ & $\begin{array}{c}\text { Moment @ } \\
\text { Midspan (ft-kip) }\end{array}$ & $\begin{array}{c}\text { Back-Calc. } \\
\text { Appl. Load (kip) }\end{array}$ \\
\hline 0 & 0 & 0 & 0 \\
\hline 9.25 & 87.32 & 110.14 & 11.91 \\
\hline 18.50 & 150.75 & 190.15 & 20.56 \\
\hline 27.75 & 214.20 & 270.18 & 29.21 \\
\hline 37.00 & 277.76 & 350.36 & 37.88 \\
\hline 46.25 & 339.96 & 428.82 & 46.36 \\
\hline 55.50 & 402.84 & 508.13 & 54.93 \\
\hline 64.75 & 465.56 & 587.24 & 63.48 \\
\hline 74.00 & 527.73 & 665.66 & 71.96 \\
\hline 83.25 & 590.44 & 744.76 & 80.51 \\
\hline 92.50 & 652.99 & 823.66 & 89.04 \\
\hline
\end{tabular}

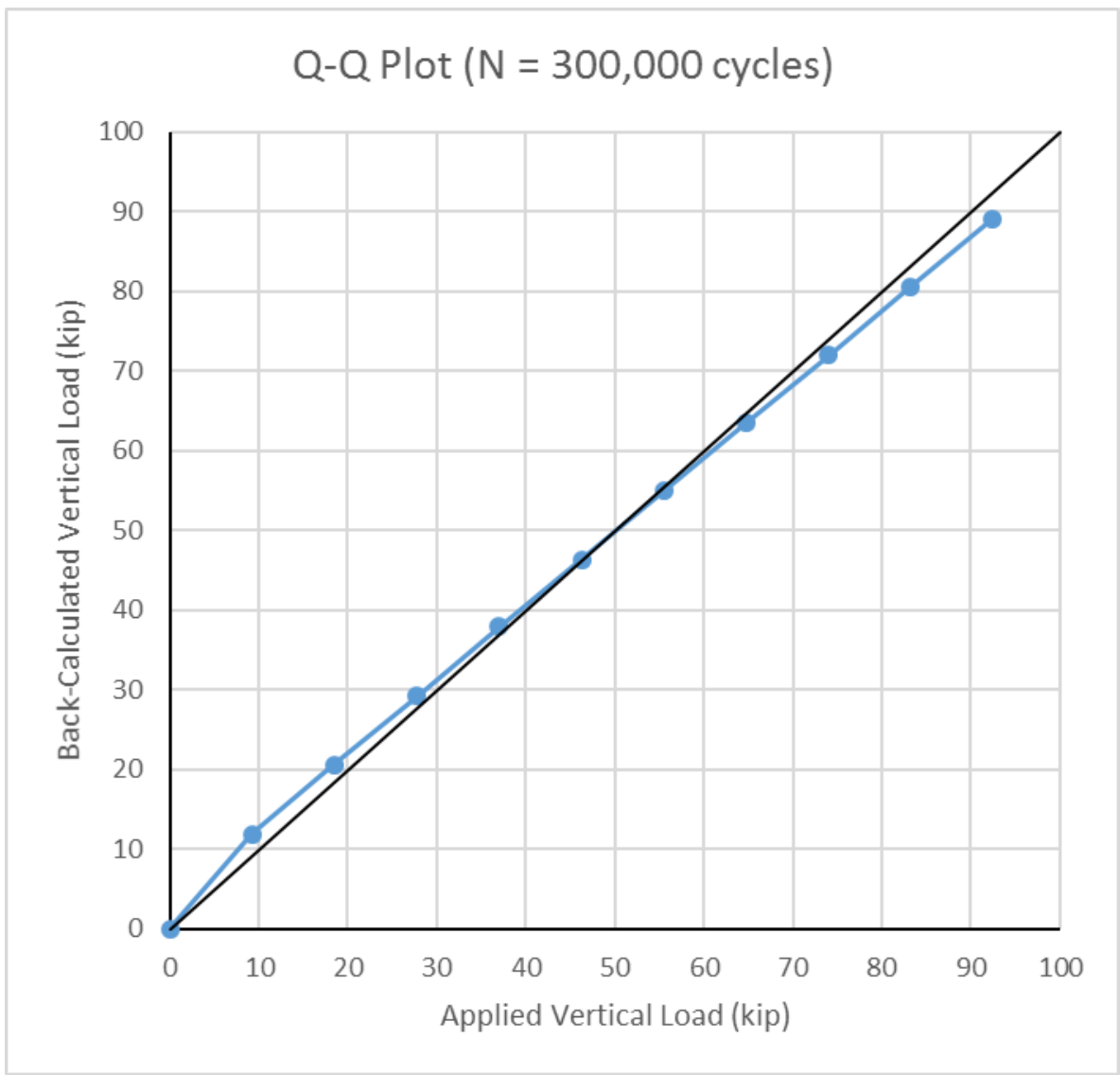

Figure 5.4: Experimental vs. Theoretical Loads at 300,000 Cycles 
Table 5.7: Load Test Summary at 500,000 Cycles

\begin{tabular}{|c|c|c|c|}
\hline $\begin{array}{c}|c| \\
\text { Load Test Summary (N=500,000) } \\
\text { Load, P (kip) }\end{array}$ & $\begin{array}{c}\text { Moment @ } \\
\text { Gage Loc. (ft-kip) }\end{array}$ & $\begin{array}{c}\text { Moment @ } \\
\text { Midspan (ft-kip) }\end{array}$ & $\begin{array}{c}\text { Back-Calc. } \\
\text { Appl. Load (kip) }\end{array}$ \\
\hline 0 & 0 & 0 & 0 \\
\hline 9.25 & 87.59 & 110.48 & 11.94 \\
\hline 18.50 & 151.76 & 191.43 & 20.69 \\
\hline 27.75 & 216.09 & 272.57 & 29.47 \\
\hline 37.00 & 279.25 & 352.23 & 38.08 \\
\hline 46.25 & 342.43 & 431.93 & 46.70 \\
\hline 55.50 & 405.45 & 511.42 & 55.29 \\
\hline 64.75 & 468.14 & 590.50 & 63.84 \\
\hline 74.00 & 531.68 & 670.64 & 72.50 \\
\hline 83.25 & 594.02 & 749.28 & 81.00 \\
\hline 92.50 & 657.48 & 829.32 & 89.66 \\
\hline
\end{tabular}

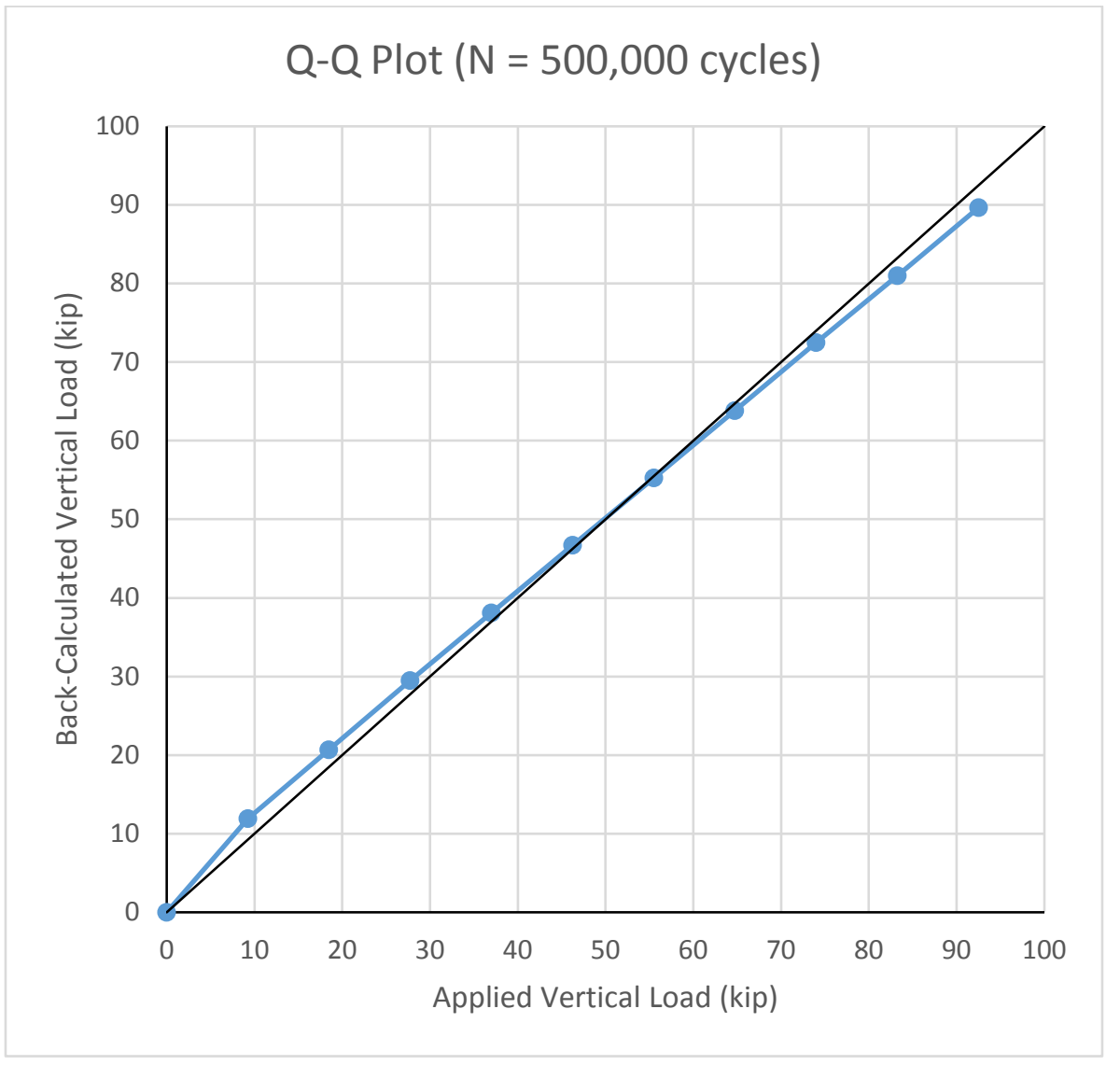

Figure 5.5: Experimental vs. Theoretical Loads at 500,000 Cycles 
Table 5.8: Load Test Summary at 700,000 Cycles

\begin{tabular}{|c|c|c|c|}
\hline $\begin{array}{c}|c| \\
\text { Load Test Summary (N=700,000) } \\
\text { Load, P (kip) }\end{array}$ & $\begin{array}{c}\text { Moment @ } \\
\text { Gage Loc. (ft-kip) }\end{array}$ & $\begin{array}{c}\text { Moment @ } \\
\text { Midspan (ft-kip) }\end{array}$ & $\begin{array}{c}\text { Back-Calc. } \\
\text { Appl. Load (kip) }\end{array}$ \\
\hline 0 & 0 & 0 & 0 \\
\hline 9.25 & 87.92 & 110.90 & 11.99 \\
\hline 18.50 & 152.70 & 192.61 & 20.82 \\
\hline 27.75 & 217.19 & 273.96 & 29.62 \\
\hline 37.00 & 280.44 & 353.74 & 38.24 \\
\hline 46.25 & 343.62 & 433.43 & 46.86 \\
\hline 55.50 & 406.18 & 512.34 & 55.39 \\
\hline 64.75 & 468.99 & 591.56 & 63.95 \\
\hline 74.00 & 531.32 & 670.19 & 72.45 \\
\hline 83.25 & 594.36 & 749.70 & 81.05 \\
\hline 92.50 & 657.22 & 828.99 & 89.62 \\
\hline
\end{tabular}

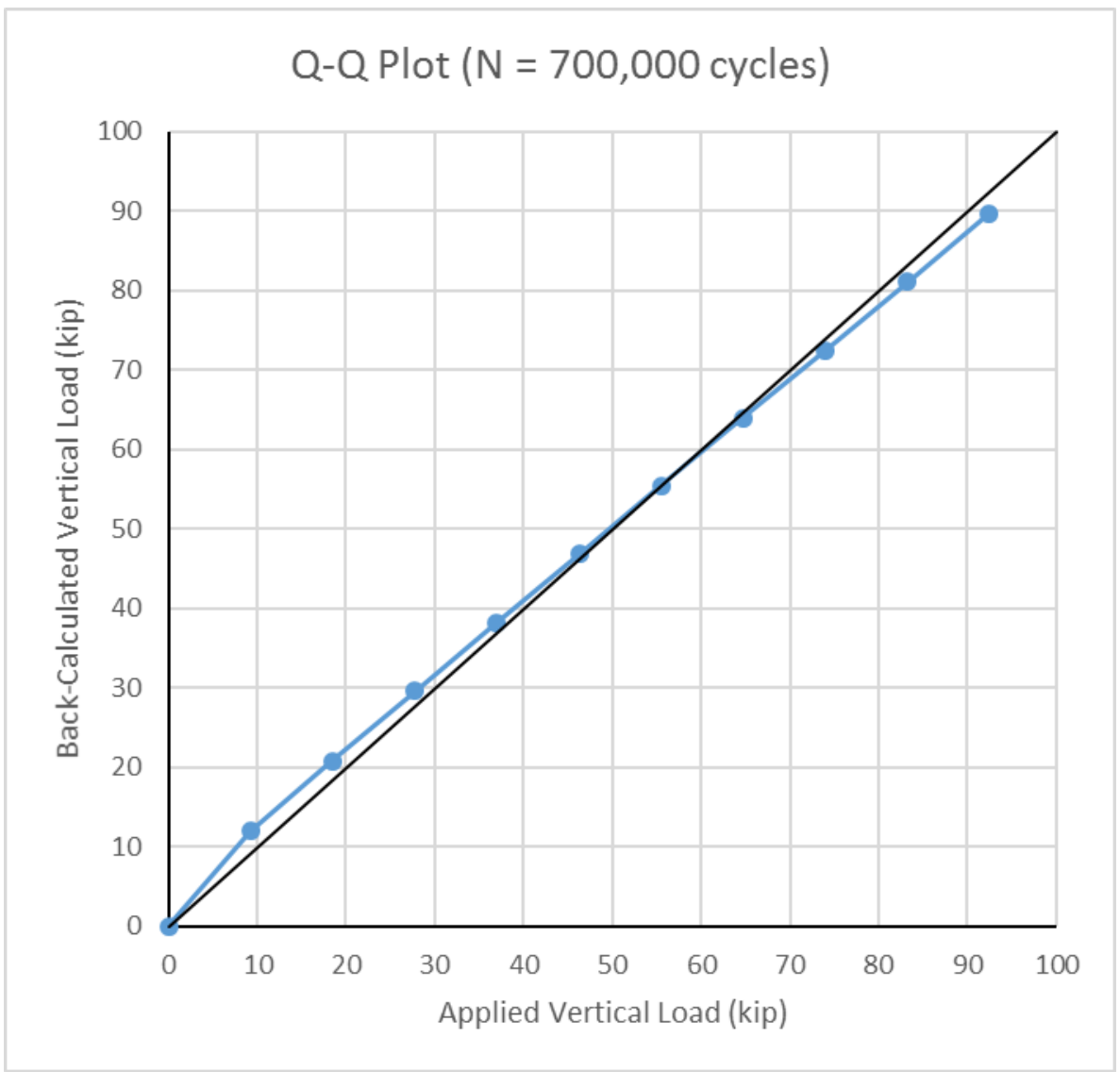

Figure 5.6: Experimental vs. Theoretical Loads at 700,000 Cycles 
Table 5.9: Load Test Summary at 900,000 Cycles

\begin{tabular}{|c|c|c|c|}
\hline $\begin{array}{c}|c| \\
\text { Load Test Summary (N=900,000) } \\
\text { Load, P (kip) }\end{array}$ & $\begin{array}{c}\text { Moment @ } \\
\text { Gage Loc. (ft-kip) }\end{array}$ & $\begin{array}{c}\text { Moment @ } \\
\text { Midspan (ft-kip) }\end{array}$ & $\begin{array}{c}\text { Back-Calc. } \\
\text { Appl. Load (kip) }\end{array}$ \\
\hline 0 & 0 & 0 & 0 \\
\hline 9.25 & 88.65 & 111.82 & 12.09 \\
\hline 18.50 & 153.48 & 193.60 & 20.93 \\
\hline 27.75 & 217.25 & 274.04 & 29.63 \\
\hline 37.00 & 280.34 & 353.61 & 38.23 \\
\hline 46.25 & 342.89 & 432.51 & 46.76 \\
\hline 55.50 & 405.61 & 511.62 & 55.31 \\
\hline 64.75 & 467.93 & 590.23 & 63.81 \\
\hline 74.00 & 529.75 & 668.21 & 72.24 \\
\hline 83.25 & 592.73 & 747.64 & 80.83 \\
\hline 92.50 & 654.89 & 826.05 & 89.30 \\
\hline
\end{tabular}

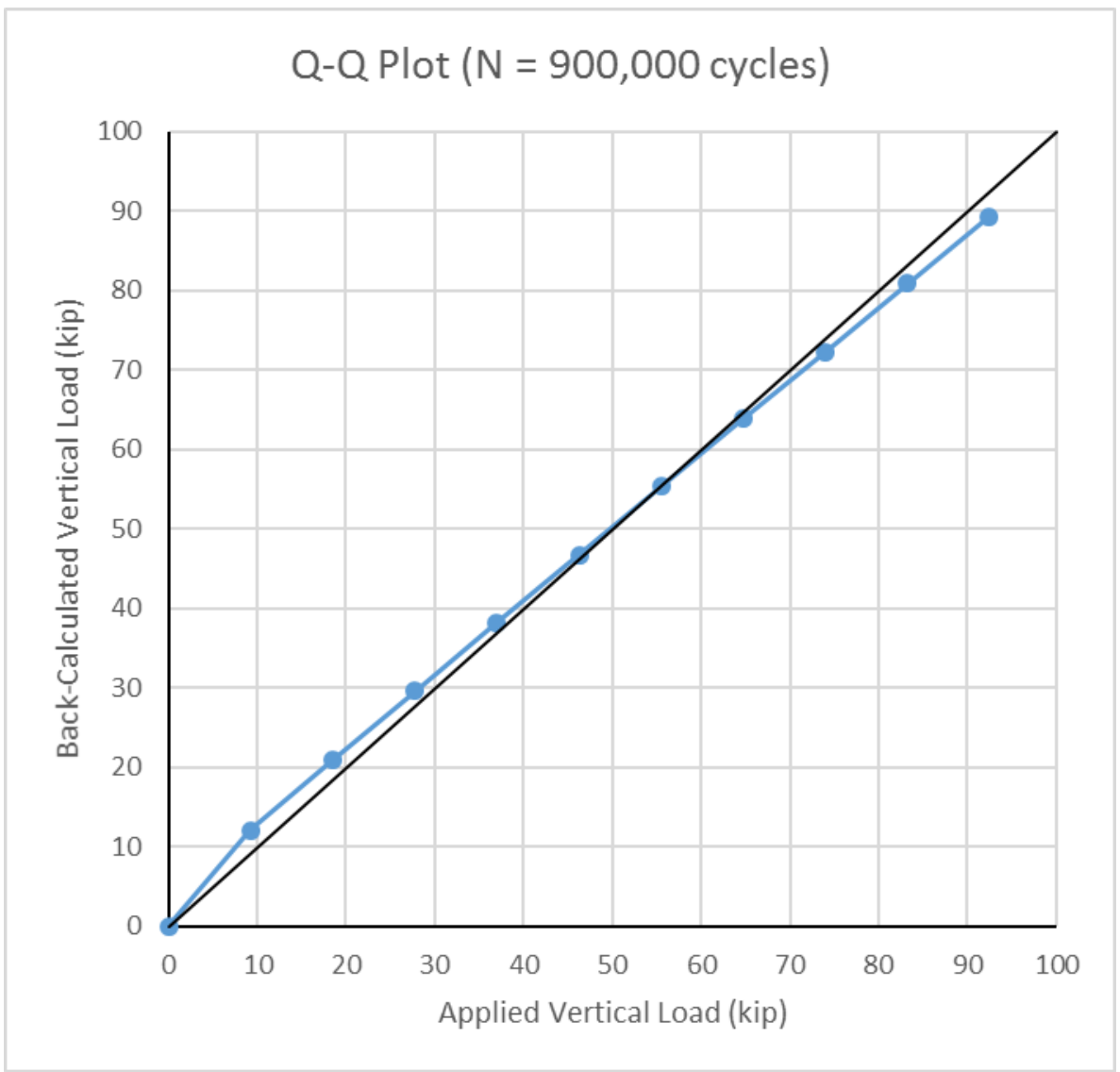

Figure 5.7: Experimental vs. Theoretical Loads at 900,000 Cycles 
Table 5.10: Load Test Summary at 1,100,000 Cycles

\begin{tabular}{|c|c|c|c|}
\hline $\begin{array}{c}\text { Load Test Summary (N=1,100,000) } \\
\text { Applied } \\
\text { Load, P (kip) }\end{array}$ & $\begin{array}{c}\text { Moment @ } \\
\text { Gage Loc. (ft-kip) }\end{array}$ & $\begin{array}{c}\text { Moment @ } \\
\text { Midspan (ft-kip) }\end{array}$ & $\begin{array}{c}\text { Back-Calc. } \\
\text { Appl. Load (kip) }\end{array}$ \\
\hline 0 & 0 & 0 & 0 \\
\hline 9.25 & 89.36 & 112.71 & 12.19 \\
\hline 18.50 & 154.06 & 194.32 & 21.01 \\
\hline 27.75 & 218.54 & 275.66 & 29.80 \\
\hline 37.00 & 282.12 & 355.85 & 38.47 \\
\hline 46.25 & 345.33 & 435.59 & 47.09 \\
\hline 55.50 & 408.33 & 515.05 & 55.68 \\
\hline 64.75 & 471.42 & 594.63 & 64.28 \\
\hline 74.00 & 534.63 & 674.36 & 72.90 \\
\hline 83.25 & 597.53 & 753.70 & 81.48 \\
\hline 92.50 & 660.70 & 833.38 & 90.10 \\
\hline
\end{tabular}

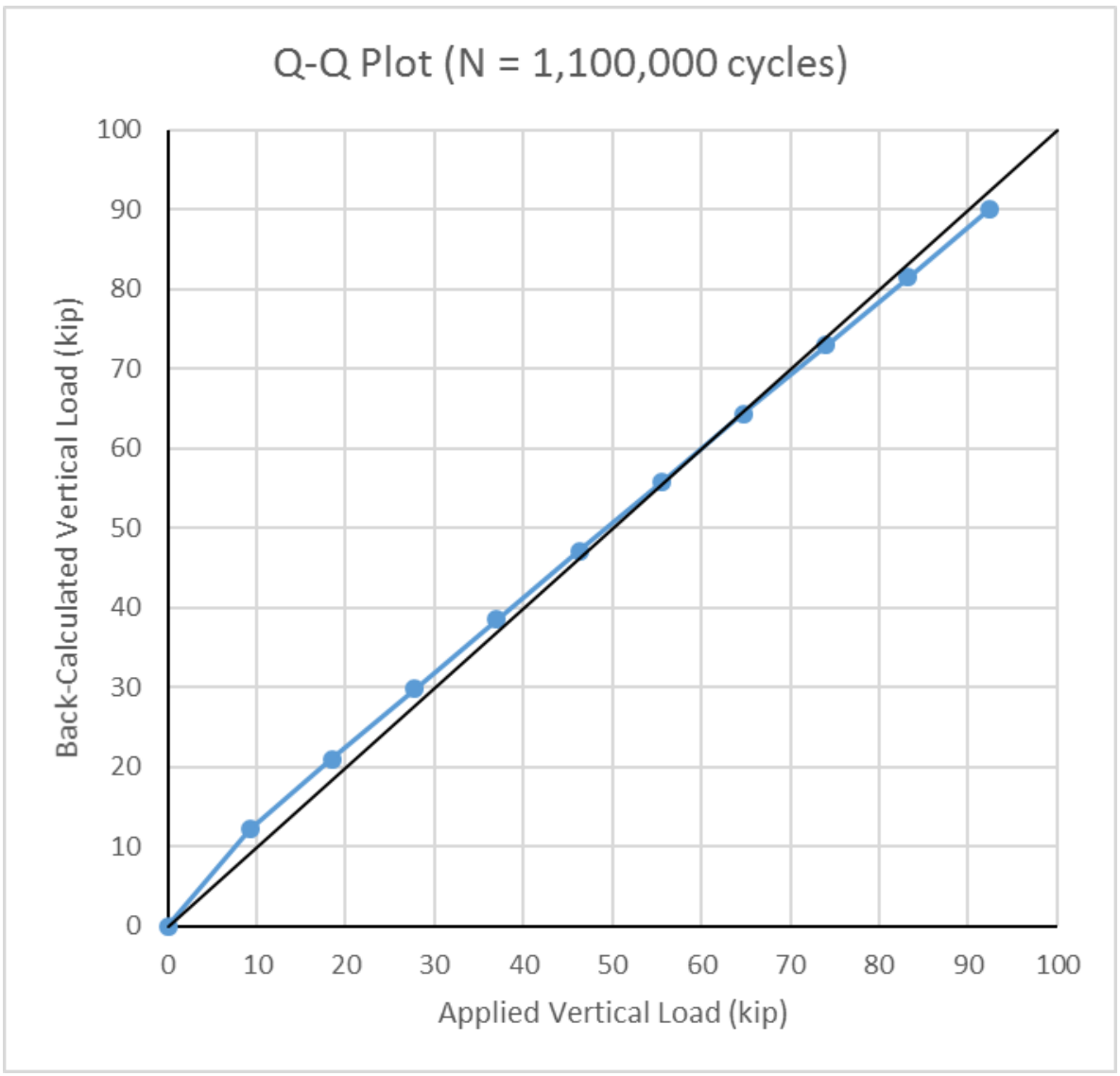

Figure 5.8: Experimental vs. Theoretical Loads at 1,100,000 Cycles 
Table 5.11: Load Test Summary at 1,300,000 Cycles

\begin{tabular}{|c|c|c|c|}
\hline $\begin{array}{c}\text { Load Test Summary (N=1,300,000) } \\
\text { Applied } \\
\text { Load, P (kip) }\end{array}$ & $\begin{array}{c}\text { Moment @ } \\
\text { Gage Loc. (ft-kip) }\end{array}$ & $\begin{array}{c}\text { Moment @ } \\
\text { Midspan (ft-kip) }\end{array}$ & $\begin{array}{c}\text { Back-Calc. } \\
\text { Appl. Load (kip) }\end{array}$ \\
\hline 0 & 0 & 0 & 0 \\
\hline 9.25 & 91.94 & 115.97 & 12.54 \\
\hline 18.50 & 156.91 & 197.92 & 21.40 \\
\hline 27.75 & 221.41 & 279.28 & 30.19 \\
\hline 37.00 & 286.05 & 360.82 & 39.01 \\
\hline 46.25 & 350.02 & 441.50 & 47.73 \\
\hline 55.50 & 413.01 & 520.95 & 56.32 \\
\hline 64.75 & 476.38 & 600.88 & 64.96 \\
\hline 74.00 & 540.05 & 681.20 & 73.64 \\
\hline 83.25 & 605.15 & 763.31 & 82.52 \\
\hline 92.50 & 668.45 & 843.16 & 91.15 \\
\hline
\end{tabular}

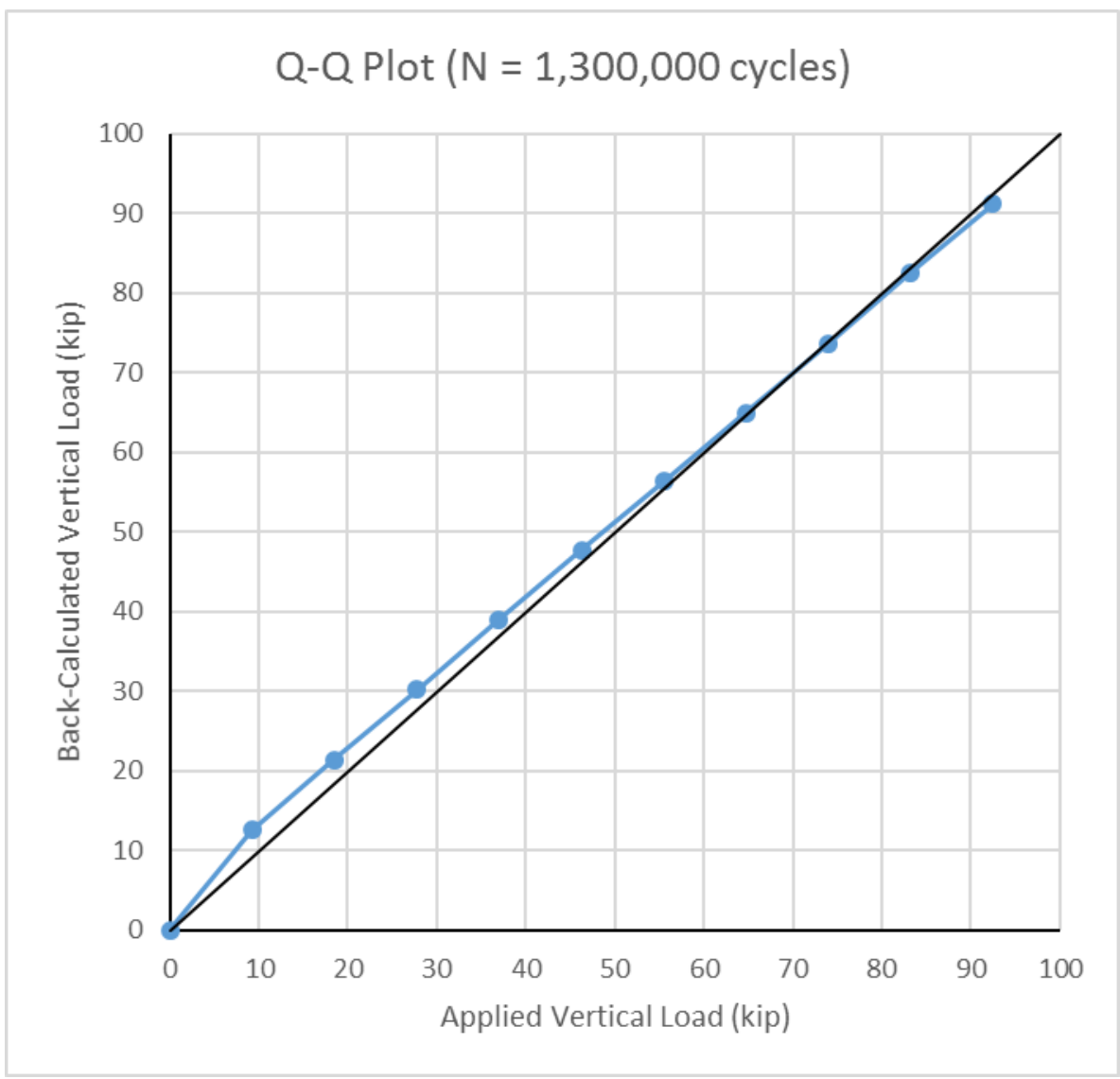

Figure 5.9: Experimental vs. Theoretical Loads at 1,300,000 Cycles 
Table 5.12: Load Test Summary at 1,500,000 Cycles

\begin{tabular}{|c|c|c|c|}
\hline $\begin{array}{c}\text { Load Test Summary (N=1,500,000) } \\
\text { Applied } \\
\text { Load, P (kip) }\end{array}$ & $\begin{array}{c}\text { Moment @ } \\
\text { Gage Loc. (ft-kip) }\end{array}$ & $\begin{array}{c}\text { Moment @ } \\
\text { Midspan (ft-kip) }\end{array}$ & $\begin{array}{c}\text { Back-Calc. } \\
\text { Appl. Load (kip) }\end{array}$ \\
\hline 0 & 0 & 0 & 0 \\
\hline 9.25 & 87.65 & 110.56 & 11.95 \\
\hline 18.50 & 152.23 & 192.02 & 20.76 \\
\hline 27.75 & 216.82 & 273.49 & 29.57 \\
\hline 37.00 & 280.70 & 354.07 & 38.28 \\
\hline 46.25 & 344.09 & 434.02 & 46.92 \\
\hline 55.50 & 406.97 & 513.34 & 55.50 \\
\hline 64.75 & 469.76 & 592.54 & 64.06 \\
\hline 74.00 & 532.75 & 671.99 & 72.65 \\
\hline 83.25 & 595.79 & 751.51 & 81.24 \\
\hline 92.50 & 658.52 & 830.64 & 89.80 \\
\hline
\end{tabular}

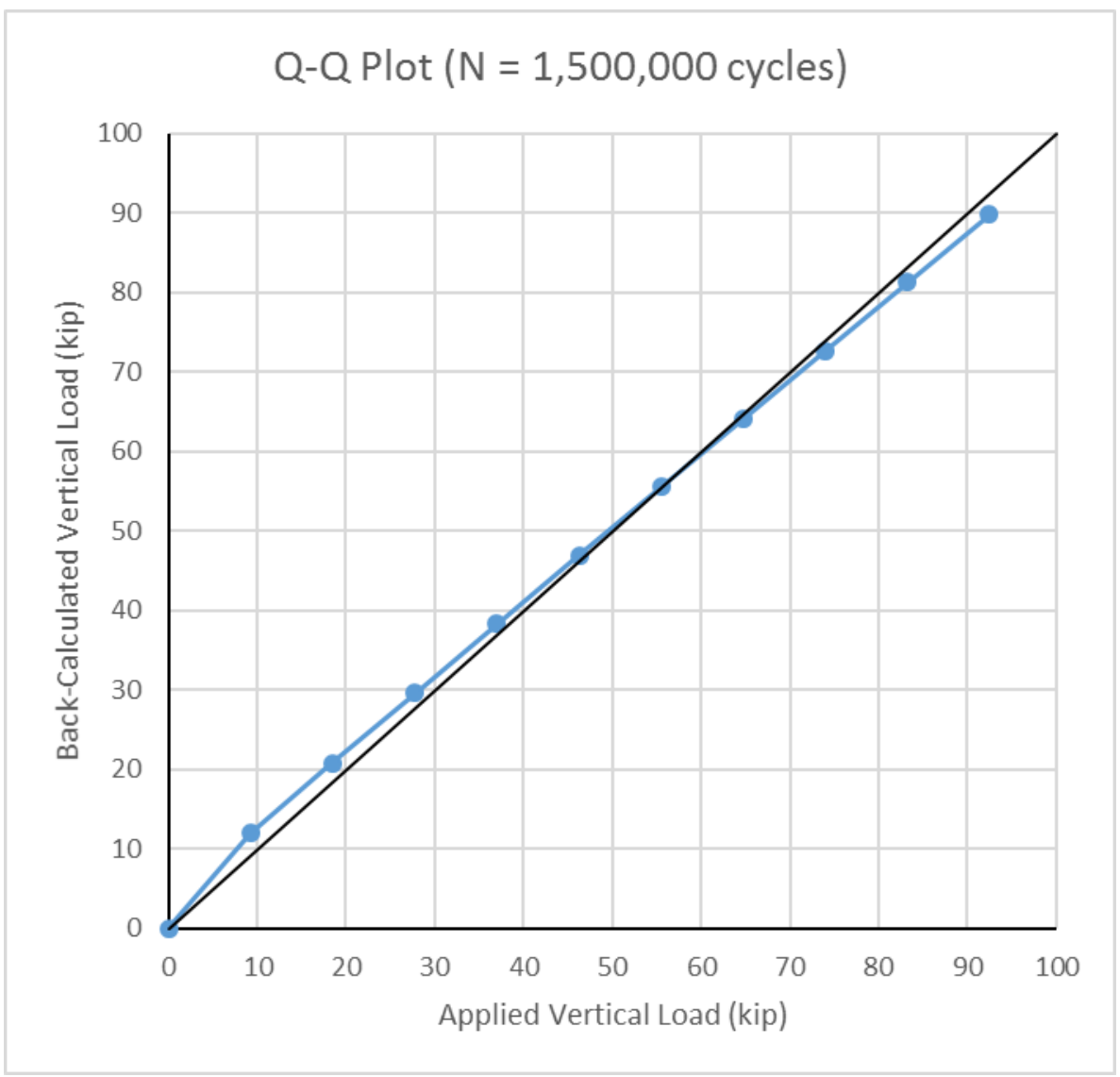

Figure 5.10: Experimental vs. Theoretical Loads at 1,500,000 Cycles 
Table 5.13: Load Test Summary at 1,700,000 Cycles

\begin{tabular}{|c|c|c|c|}
\hline $\begin{array}{c}\text { Load Test Summary (N=1,700,000) } \\
\text { Applied } \\
\text { Load, P (kip) }\end{array}$ & $\begin{array}{c}\text { Moment @ } \\
\text { Gage Loc. (ft-kip) }\end{array}$ & $\begin{array}{c}\text { Moment @ } \\
\text { Midspan (ft-kip) }\end{array}$ & $\begin{array}{c}\text { Back-Calc. } \\
\text { Appl. Load (kip) }\end{array}$ \\
\hline 0 & 0 & 0 & 0 \\
\hline 9.25 & 86.70 & 109.36 & 11.82 \\
\hline 18.50 & 152.14 & 191.90 & 20.75 \\
\hline 27.75 & 216.26 & 272.79 & 29.49 \\
\hline 37.00 & 280.20 & 353.43 & 38.21 \\
\hline 46.25 & 343.37 & 433.11 & 46.82 \\
\hline 55.50 & 406.80 & 513.12 & 55.47 \\
\hline 64.75 & 469.34 & 592.01 & 64.00 \\
\hline 74.00 & 532.62 & 671.83 & 72.63 \\
\hline 83.25 & 596.57 & 752.49 & 81.35 \\
\hline 92.50 & 659.78 & 832.23 & 89.97 \\
\hline
\end{tabular}

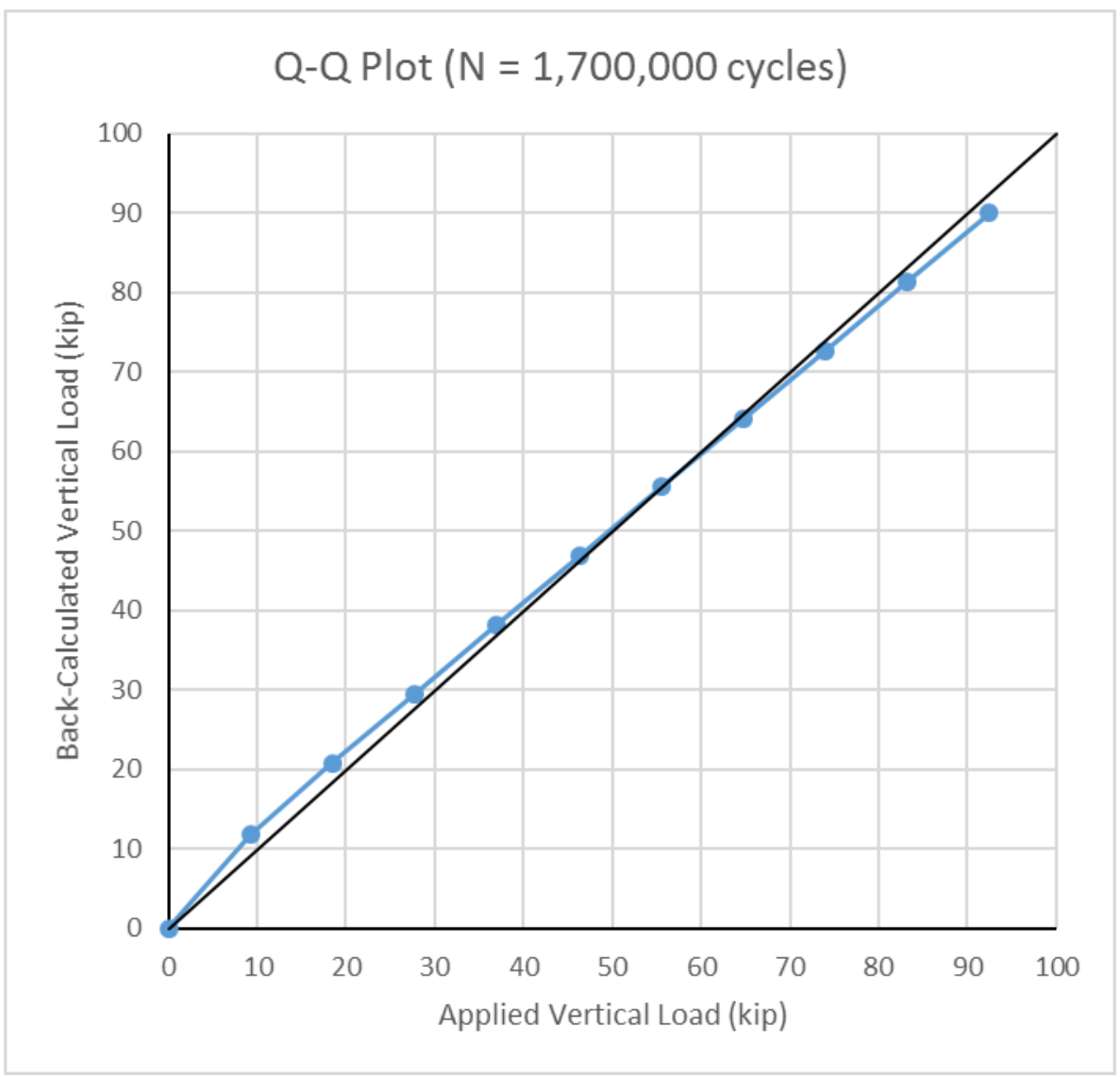

Figure 5.11: Experimental vs. Theoretical Loads at 1,700,000 Cycles 
Table 5.14: Load Test Summary at 1,900,000 Cycles

\begin{tabular}{|c|c|c|c|}
\hline $\begin{array}{c}\text { Load Test Summary (N=1,900,000) } \\
\text { Applied } \\
\text { Load, P (kip) }\end{array}$ & $\begin{array}{c}\text { Moment @ } \\
\text { Gage Loc. (ft-kip) }\end{array}$ & $\begin{array}{c}\text { Moment @ } \\
\text { Midspan (ft-kip) }\end{array}$ & $\begin{array}{c}\text { Back-Calc. } \\
\text { Appl. Load (kip) }\end{array}$ \\
\hline 0 & 0 & 0 & 0 \\
\hline 9.25 & 91.87 & 115.89 & 12.53 \\
\hline 18.50 & 157.12 & 198.19 & 21.43 \\
\hline 27.75 & 221.73 & 279.68 & 30.24 \\
\hline 37.00 & 286.02 & 360.77 & 39.00 \\
\hline 46.25 & 349.88 & 441.32 & 47.71 \\
\hline 55.50 & 413.29 & 521.31 & 56.36 \\
\hline 64.75 & 476.88 & 601.52 & 65.03 \\
\hline 74.00 & 540.35 & 681.58 & 73.68 \\
\hline 83.25 & 603.87 & 761.70 & 82.35 \\
\hline 92.50 & 667.48 & 841.93 & 91.02 \\
\hline
\end{tabular}

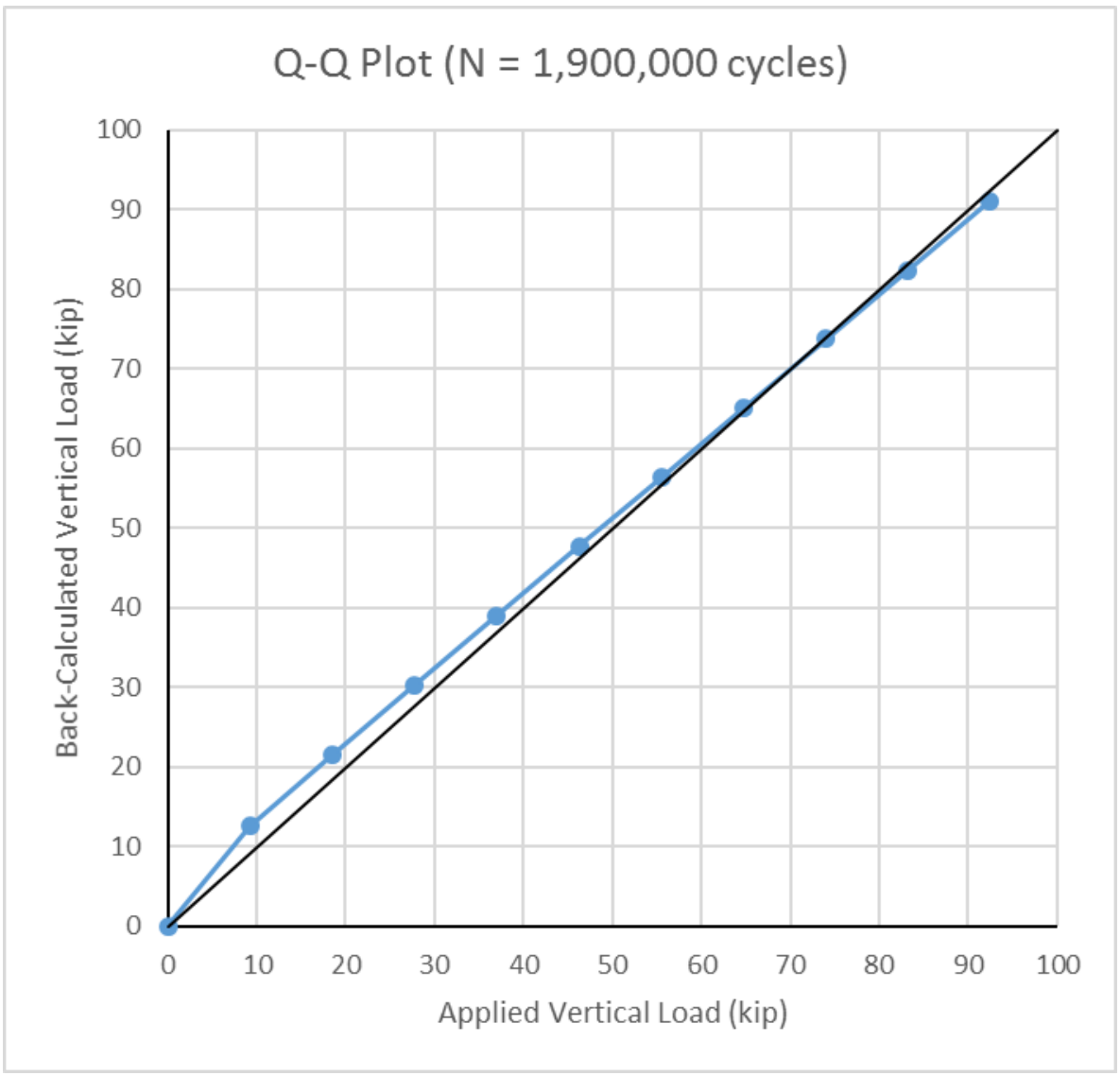

Figure 5.12: Experimental vs. Theoretical Loads at 1,900,000 Cycles 
Table 5.15: Load Test Summary at 2,100,000 Cycles

\begin{tabular}{|c|c|c|c|}
\hline $\begin{array}{c}\text { Load Test Summary (N=2,100,000) } \\
\text { Applied } \\
\text { Load, P (kip) }\end{array}$ & $\begin{array}{c}\text { Moment @ } \\
\text { Gage Loc. (ft-kip) }\end{array}$ & $\begin{array}{c}\text { Moment @ } \\
\text { Midspan (ft-kip) }\end{array}$ & $\begin{array}{c}\text { Back-Calc. } \\
\text { Appl. Load (kip) }\end{array}$ \\
\hline 0 & 0 & 0 & 0 \\
\hline 9.25 & 91.47 & 115.38 & 12.47 \\
\hline 18.50 & 157.18 & 198.26 & 21.43 \\
\hline 27.75 & 221.54 & 279.45 & 30.21 \\
\hline 37.00 & 285.78 & 360.48 & 38.97 \\
\hline 46.25 & 349.65 & 441.04 & 47.68 \\
\hline 55.50 & 413.19 & 521.18 & 56.34 \\
\hline 64.75 & 477.01 & 601.68 & 65.05 \\
\hline 74.00 & 540.38 & 681.62 & 73.69 \\
\hline 83.25 & 604.29 & 762.23 & 82.40 \\
\hline 92.50 & 667.28 & 841.68 & 90.99 \\
\hline
\end{tabular}

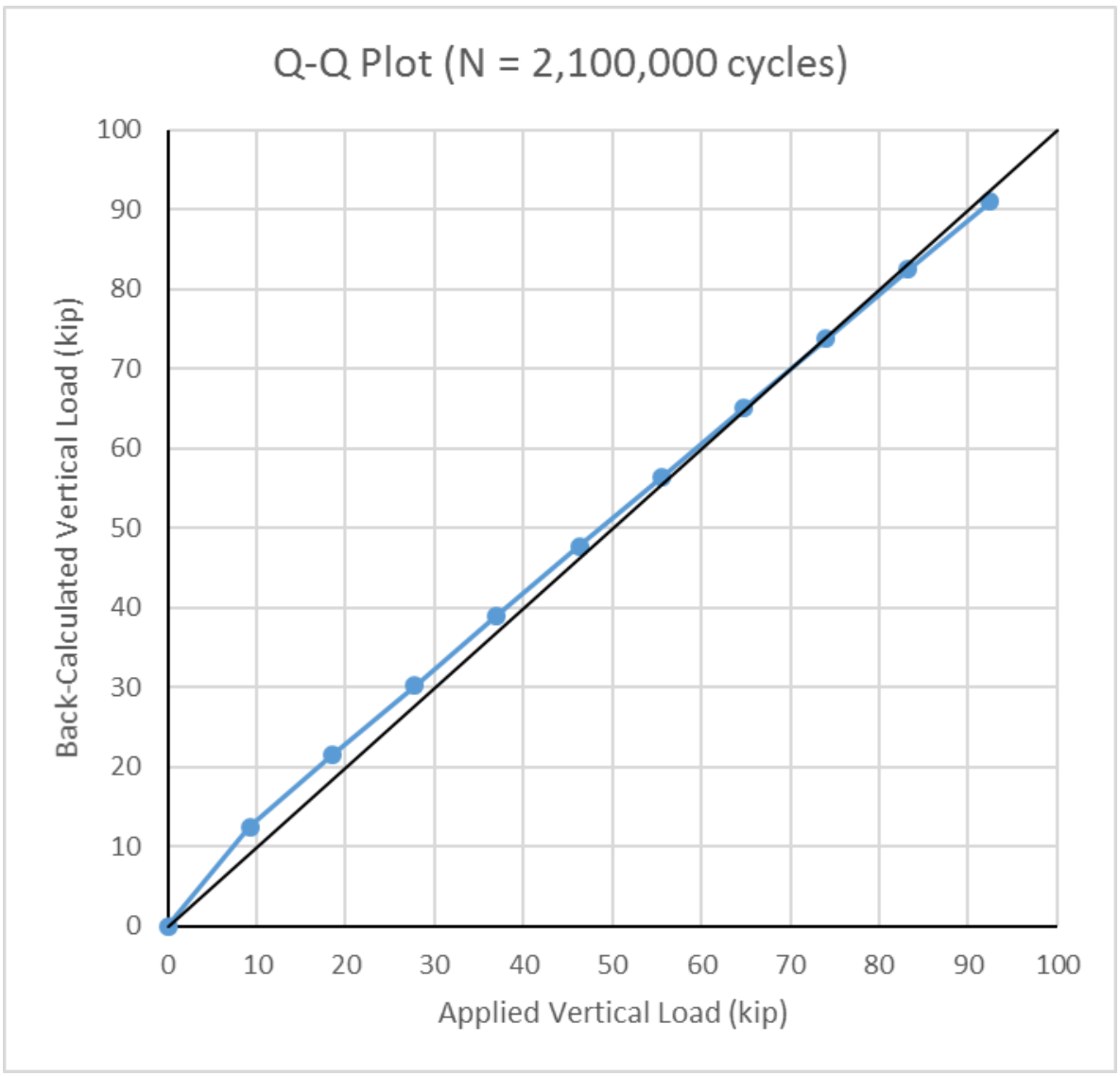

Figure 5.13: Experimental vs. Theoretical Loads at 2,100,000 Cycles 
Table 5.16: Load Test Summary at 2,300,000 Cycles

\begin{tabular}{|c|c|c|c|}
\hline $\begin{array}{c}|c| \\
\text { Applied } \\
\text { Load, P (kip) }\end{array}$ & $\begin{array}{c}\text { Moment @ } \\
\text { Gage Loc. (ft-kip) }\end{array}$ & $\begin{array}{c}\text { Moment @ } \\
\text { Midspan (ft-kip) }\end{array}$ & $\begin{array}{c}\text { Back-Calc. } \\
\text { Appl. Load (kip) }\end{array}$ \\
\hline 0 & 0 & 0 & 0 \\
\hline 9.25 & 88.44 & 111.56 & 12.06 \\
\hline 18.50 & 153.01 & 193.00 & 20.86 \\
\hline 27.75 & 216.79 & 273.45 & 29.56 \\
\hline 37.00 & 280.25 & 353.49 & 38.22 \\
\hline 46.25 & 342.97 & 432.61 & 46.77 \\
\hline 55.50 & 404.78 & 510.58 & 55.20 \\
\hline 64.75 & 466.95 & 588.99 & 63.67 \\
\hline 74.00 & 529.13 & 667.42 & 72.15 \\
\hline 83.25 & 591.70 & 746.35 & 80.69 \\
\hline 92.50 & 653.31 & 824.07 & 89.09 \\
\hline
\end{tabular}

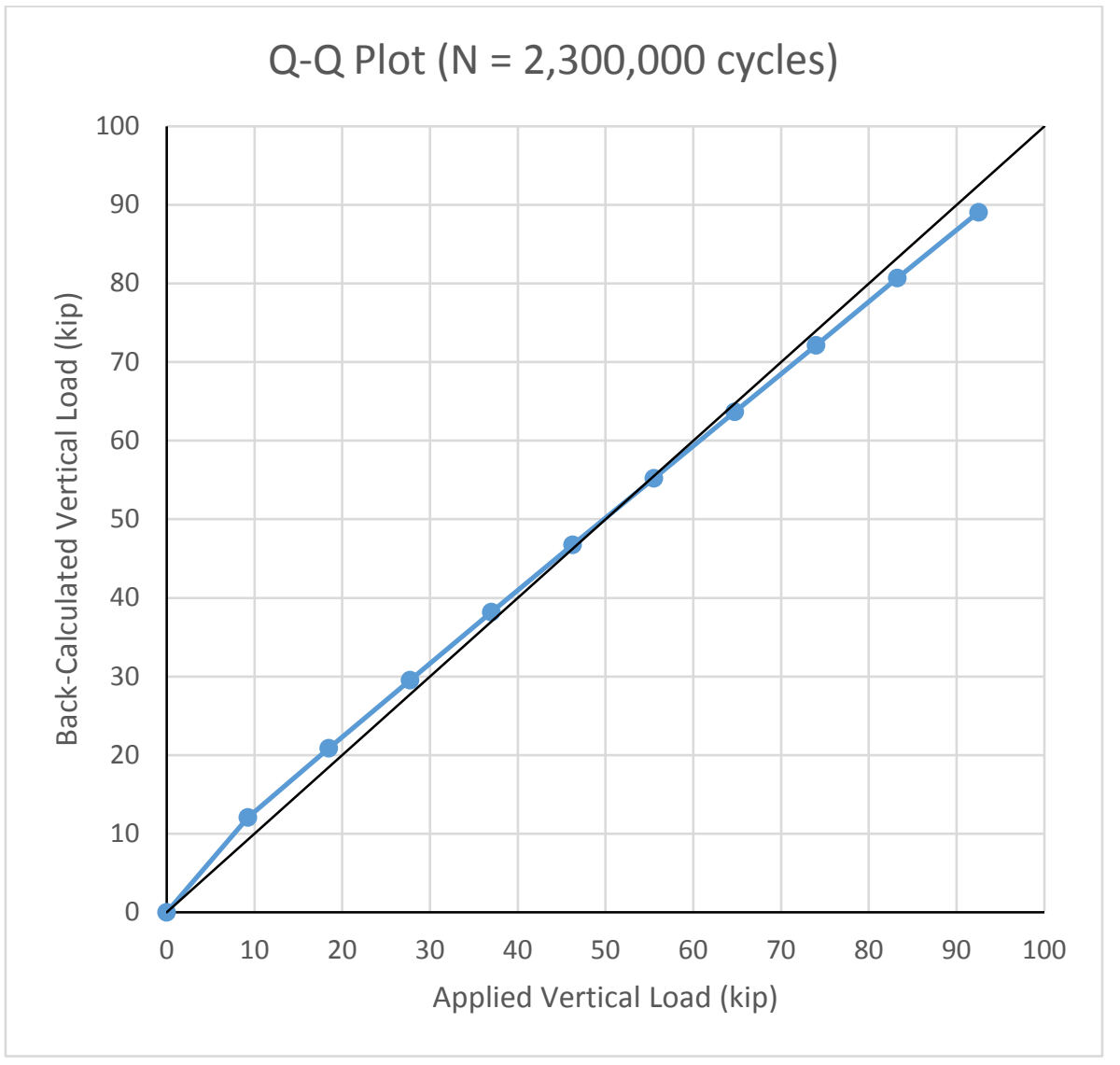

Figure 5.14: Experimental vs. Theoretical Loads at 2,300,000 Cycles 
Table 5.17: Load Test Summary at 2,500,000 Cycles

\begin{tabular}{|c|c|c|c|}
\hline $\begin{array}{c}|c| \\
\text { Applied } \\
\text { Load, P (kip) }\end{array}$ & $\begin{array}{c}\text { Moment @ } \\
\text { Gage Loc. (ft-kip) }\end{array}$ & $\begin{array}{c}\text { Moment @ } \\
\text { Midspan (ft-kip) }\end{array}$ & $\begin{array}{c}\text { Back-Calc. } \\
\text { Appl. Load (kip) }\end{array}$ \\
\hline 0 & 0 & 0 & 0 \\
\hline 9.25 & 93.79 & 118.30 & 12.79 \\
\hline 18.50 & 161.37 & 203.54 & 22.00 \\
\hline 27.75 & 227.65 & 287.15 & 31.04 \\
\hline 37.00 & 293.69 & 370.45 & 40.05 \\
\hline 46.25 & 359.17 & 453.04 & 48.98 \\
\hline 55.50 & 424.46 & 535.40 & 57.88 \\
\hline 64.75 & 489.26 & 617.14 & 66.72 \\
\hline 74.00 & 554.15 & 698.99 & 75.57 \\
\hline 83.25 & 619.19 & 781.02 & 84.44 \\
\hline 92.50 & 684.03 & 862.81 & 93.28 \\
\hline
\end{tabular}

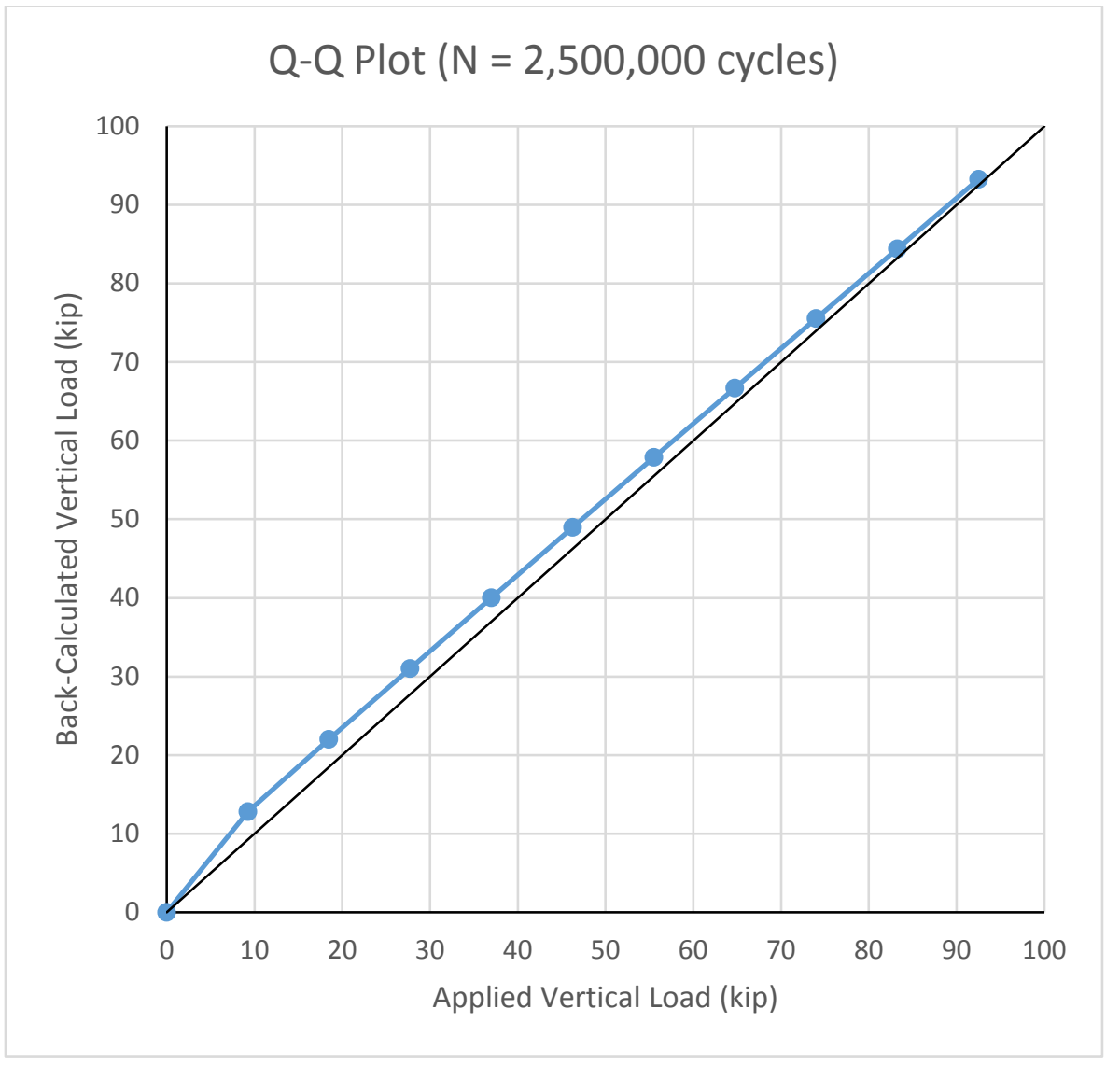

Figure 5.15: Experimental vs. Theoretical Loads at 2,500,000 Cycles 
Table 5.18: Load Test Summary at 2,700,000 Cycles

\begin{tabular}{|c|c|c|c|}
\hline $\begin{array}{c}|c| \\
\text { Applied } \\
\text { Load, P (kip) }\end{array}$ & $\begin{array}{c}\text { Moment @ } \\
\text { Gage Loc. (ft-kip) }\end{array}$ & $\begin{array}{c}\text { Moment @ } \\
\text { Midspan (ft-kip) }\end{array}$ & $\begin{array}{c}\text { Back-Calc. } \\
\text { Appl. Load (kip) }\end{array}$ \\
\hline 0 & 0 & 0 & 0 \\
\hline 9.25 & 94.29 & 118.94 & 12.86 \\
\hline 18.50 & 161.68 & 203.93 & 22.05 \\
\hline 27.75 & 228.04 & 287.65 & 31.10 \\
\hline 37.00 & 294.22 & 371.12 & 40.12 \\
\hline 46.25 & 359.32 & 453.24 & 49.00 \\
\hline 55.50 & 424.78 & 535.81 & 57.93 \\
\hline 64.75 & 489.87 & 617.90 & 66.80 \\
\hline 74.00 & 555.12 & 700.21 & 75.70 \\
\hline 83.25 & 620.19 & 782.28 & 84.57 \\
\hline 92.50 & 685.36 & 864.48 & 93.46 \\
\hline
\end{tabular}

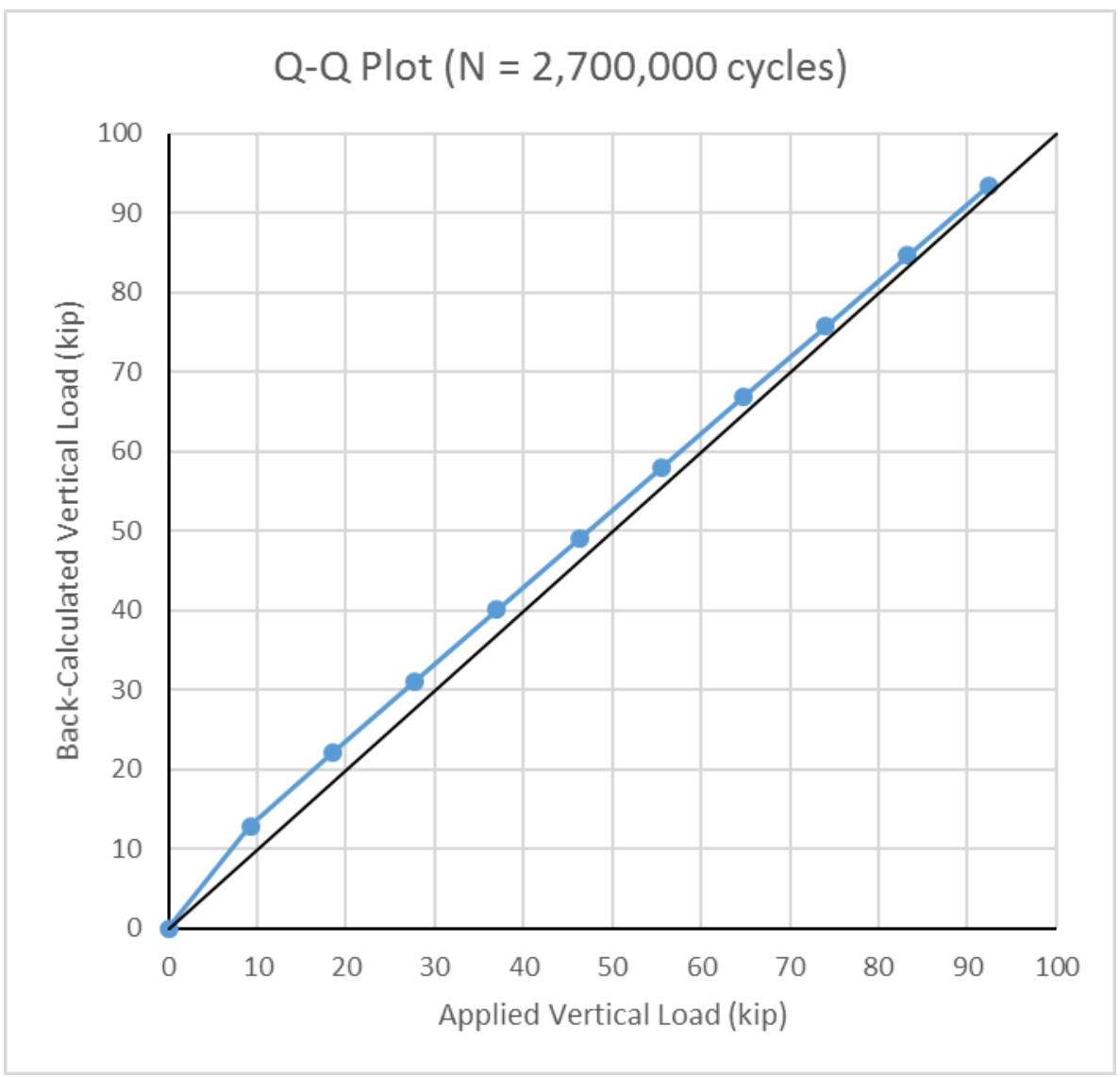

Figure 5.16: Experimental vs. Theoretical Loads at 2,700,000 Cycles 
Table 5.19: Load Test Summary at 2,900,000 Cycles

\begin{tabular}{|c|c|c|c|}
\hline $\begin{array}{c}\text { Load Test Summary (N=2,900,000) } \\
\text { Applied } \\
\text { Load, P (kip) }\end{array}$ & $\begin{array}{c}\text { Moment @ } \\
\text { Gage Loc. (ft-kip) }\end{array}$ & $\begin{array}{c}\text { Moment @ } \\
\text { Midspan (ft-kip) }\end{array}$ & $\begin{array}{c}\text { Back-Calc. } \\
\text { Appl. Load (kip) }\end{array}$ \\
\hline 0 & 0 & 0 & 0 \\
\hline 9.25 & 95.57 & 120.55 & 13.03 \\
\hline 18.50 & 163.33 & 206.02 & 22.27 \\
\hline 27.75 & 229.89 & 289.98 & 31.35 \\
\hline 37.00 & 295.84 & 373.17 & 40.34 \\
\hline 46.25 & 361.70 & 456.23 & 49.32 \\
\hline 55.50 & 426.29 & 537.71 & 58.13 \\
\hline 64.75 & 491.33 & 619.75 & 67.00 \\
\hline 74.00 & 556.22 & 701.60 & 75.85 \\
\hline 83.25 & 621.27 & 783.65 & 84.72 \\
\hline 92.50 & 686.50 & 865.93 & 93.61 \\
\hline
\end{tabular}

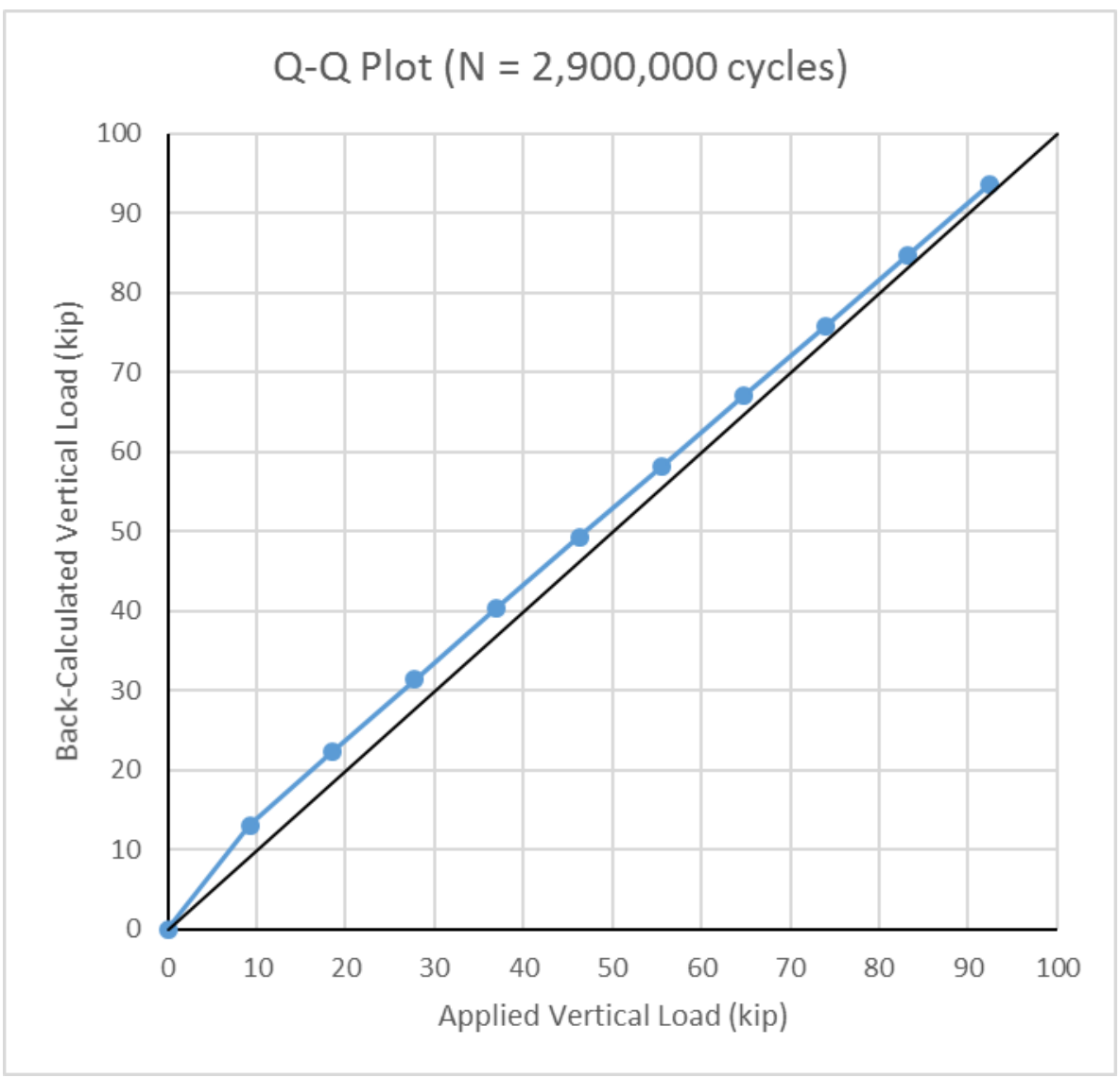

Figure 5.17: Experimental vs. Theoretical Loads at 2,900,000 Cycles 
Table 5.20: Load Test Summary at 0 Cycles

\begin{tabular}{|c|c|c|c|}
\hline $\begin{array}{c}|c| \\
\text { Applied } \\
\text { Load, P (kip) }\end{array}$ & $\begin{array}{c}\text { Moment @ } \\
\text { Gage Loc. (ft-kip) }\end{array}$ & $\begin{array}{c}\text { Moment @ } \\
\text { Midspan (ft-kip) }\end{array}$ & $\begin{array}{c}\text { Back-Calc. } \\
\text { Appl. Load (kip) }\end{array}$ \\
\hline 0 & 0 & 0 & 0 \\
\hline 9.30 & 87.09 & 109.46 & 11.68 \\
\hline 18.60 & 150.41 & 189.07 & 20.17 \\
\hline 27.90 & 213.07 & 267.83 & 28.57 \\
\hline 37.20 & 275.23 & 345.96 & 36.90 \\
\hline 46.50 & 337.87 & 424.70 & 45.30 \\
\hline 55.80 & 399.56 & 502.24 & 53.57 \\
\hline 65.10 & 460.86 & 579.30 & 61.79 \\
\hline 74.40 & 521.94 & 656.07 & 69.98 \\
\hline 83.70 & 583.02 & 732.85 & 78.17 \\
\hline 93.00 & 644.21 & 809.76 & 86.37 \\
\hline
\end{tabular}

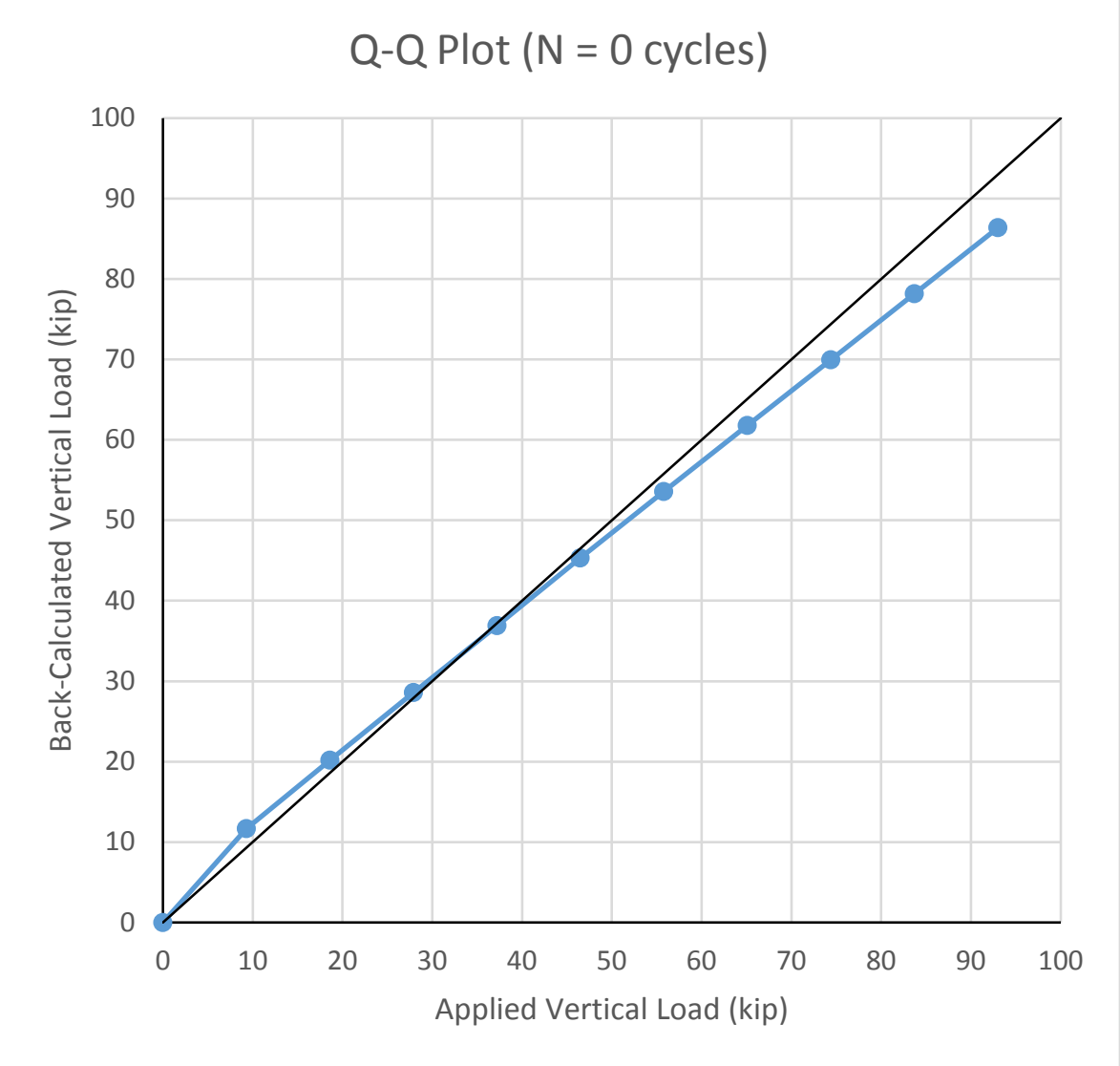

Figure 5.18: Experimental vs. Theoretical Loads at 0 Cycles 
Table 5.21: Load Test Summary at 100,000 Cycles

\begin{tabular}{|c|c|c|c|}
\hline $\begin{array}{c}\text { Load Test Summary (N=100,000) } \\
\text { Load, P (kip) }\end{array}$ & $\begin{array}{c}\text { Moment @ } \\
\text { Gage Loc. (ft-kip) }\end{array}$ & $\begin{array}{c}\text { Moment @ } \\
\text { Midspan (ft-kip) }\end{array}$ & $\begin{array}{c}\text { Back-Calc. } \\
\text { Appl. Load (kip) }\end{array}$ \\
\hline 0 & 0 & 0 & 0 \\
\hline 9.30 & 86.41 & 108.62 & 11.59 \\
\hline 18.60 & 149.13 & 187.45 & 20.00 \\
\hline 27.90 & 211.95 & 266.42 & 28.42 \\
\hline 37.20 & 274.23 & 344.70 & 36.77 \\
\hline 46.50 & 336.41 & 422.86 & 45.11 \\
\hline 55.80 & 398.24 & 500.58 & 53.39 \\
\hline 65.10 & 459.17 & 577.17 & 61.56 \\
\hline 74.40 & 520.52 & 654.29 & 69.79 \\
\hline 83.70 & 581.87 & 731.40 & 78.02 \\
\hline 93.00 & 642.98 & 808.22 & 86.21 \\
\hline
\end{tabular}

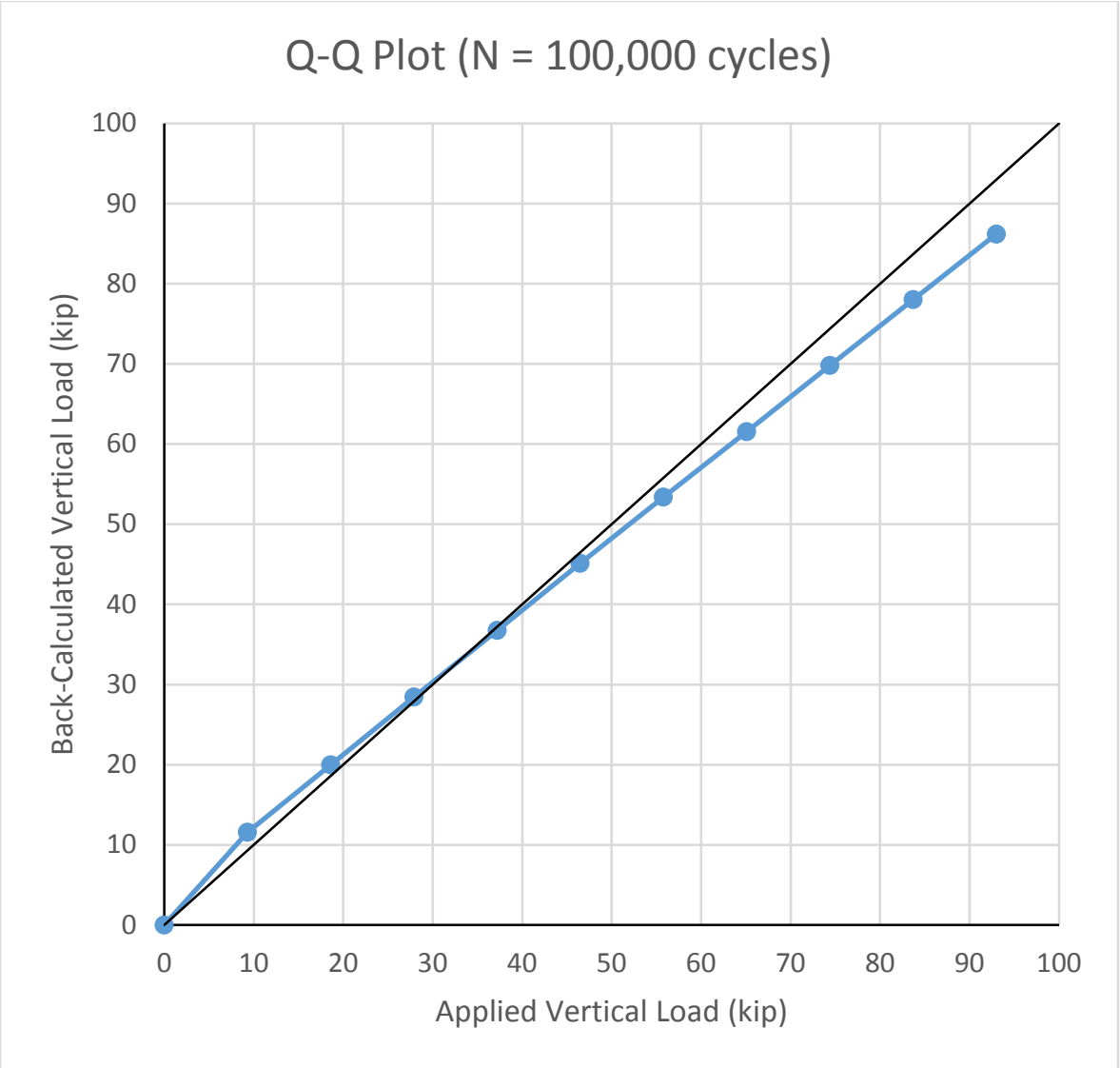

Figure 5.19: Experimental vs. Theoretical Loads at 100,000 Cycles 
Table 5.22: Load Test Summary at 200,000 Cycles

\begin{tabular}{|c|c|c|c|}
\hline $\begin{array}{c}|c| \\
\text { Load Test Summary (N=200,000) } \\
\text { Load, P (kip) }\end{array}$ & $\begin{array}{c}\text { Moment @ } \\
\text { Gage Loc. (ft-kip) }\end{array}$ & $\begin{array}{c}\text { Moment @ } \\
\text { Midspan (ft-kip) }\end{array}$ & $\begin{array}{c}\text { Back-Calc. } \\
\text { Appl. Load (kip) }\end{array}$ \\
\hline 0 & 0 & 0 & 0 \\
\hline 9.30 & 86.58 & 108.83 & 11.61 \\
\hline 18.60 & 149.37 & 187.76 & 20.03 \\
\hline 27.90 & 211.49 & 265.83 & 28.36 \\
\hline 37.20 & 273.37 & 343.62 & 36.65 \\
\hline 46.50 & 335.00 & 421.08 & 44.92 \\
\hline 55.80 & 396.87 & 498.86 & 53.21 \\
\hline 65.10 & 458.42 & 576.23 & 61.46 \\
\hline 74.40 & 520.19 & 653.86 & 69.75 \\
\hline 83.70 & 581.49 & 730.92 & 77.97 \\
\hline 93.00 & 643.31 & 808.62 & 86.25 \\
\hline
\end{tabular}

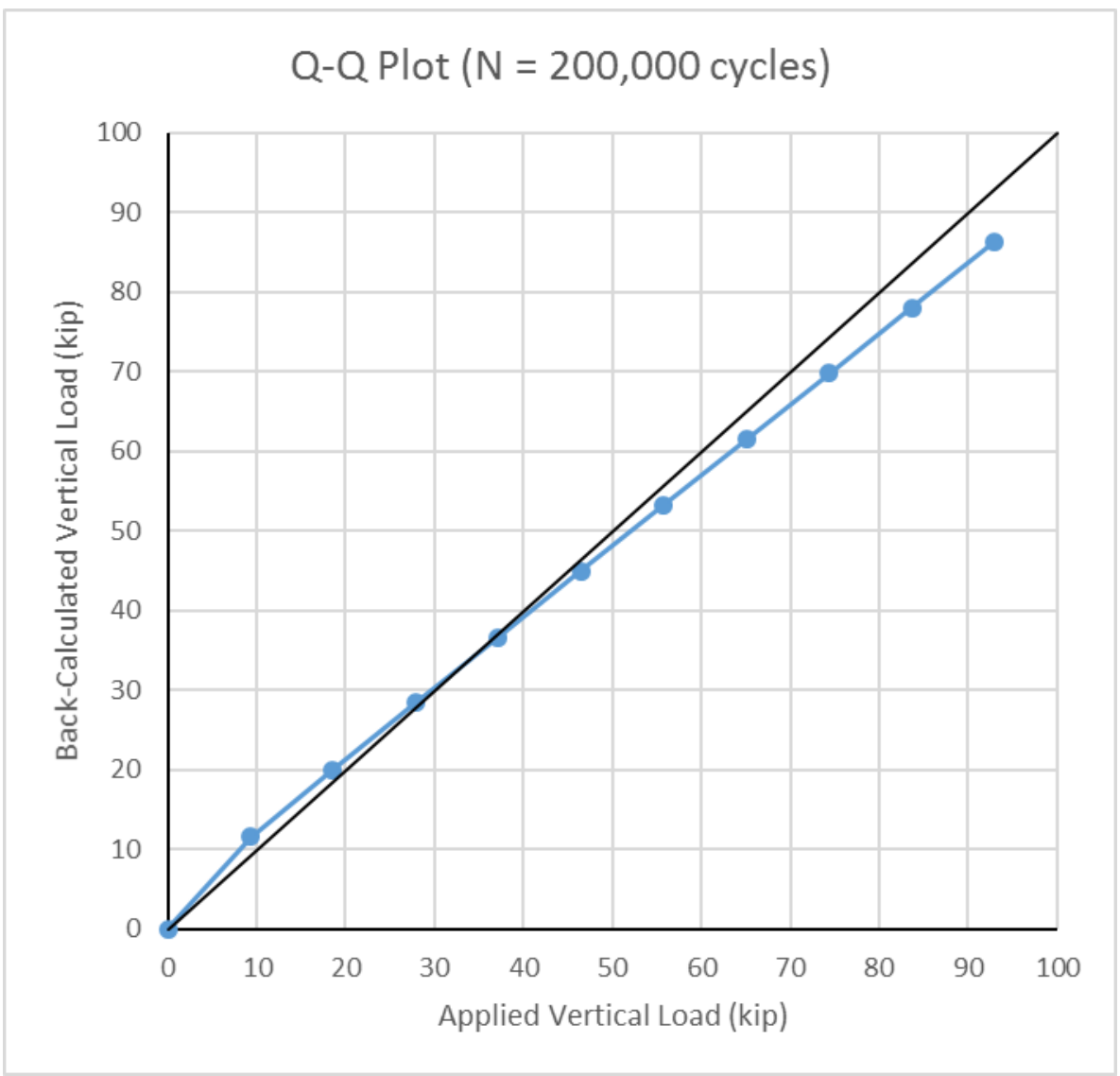

Figure 5.20: Experimental vs. Theoretical Loads at 200,000 Cycles 
Table 5.23: Load Test Summary at 300,000 Cycles

\begin{tabular}{|c|c|c|c|}
\hline $\begin{array}{c}|c| \\
\text { Load Test Summary (N=300,000) } \\
\text { Load, P (kip) }\end{array}$ & $\begin{array}{c}\text { Moment @ } \\
\text { Gage Loc. (ft-kip) }\end{array}$ & $\begin{array}{c}\text { Moment @ } \\
\text { Midspan (ft-kip) }\end{array}$ & $\begin{array}{c}\text { Back-Calc. } \\
\text { Appl. Load (kip) }\end{array}$ \\
\hline 0 & 0 & 0 & 0 \\
\hline 9.30 & 88.21 & 110.88 & 11.83 \\
\hline 18.60 & 152.69 & 191.93 & 20.47 \\
\hline 27.90 & 216.56 & 272.22 & 29.04 \\
\hline 37.20 & 279.89 & 351.82 & 37.53 \\
\hline 46.50 & 342.88 & 431.00 & 45.97 \\
\hline 55.80 & 405.42 & 509.60 & 54.36 \\
\hline 65.10 & 467.87 & 588.11 & 62.73 \\
\hline 74.40 & 529.73 & 665.86 & 71.03 \\
\hline 83.70 & 591.76 & 743.83 & 79.34 \\
\hline 93.00 & 653.30 & 821.19 & 87.59 \\
\hline
\end{tabular}

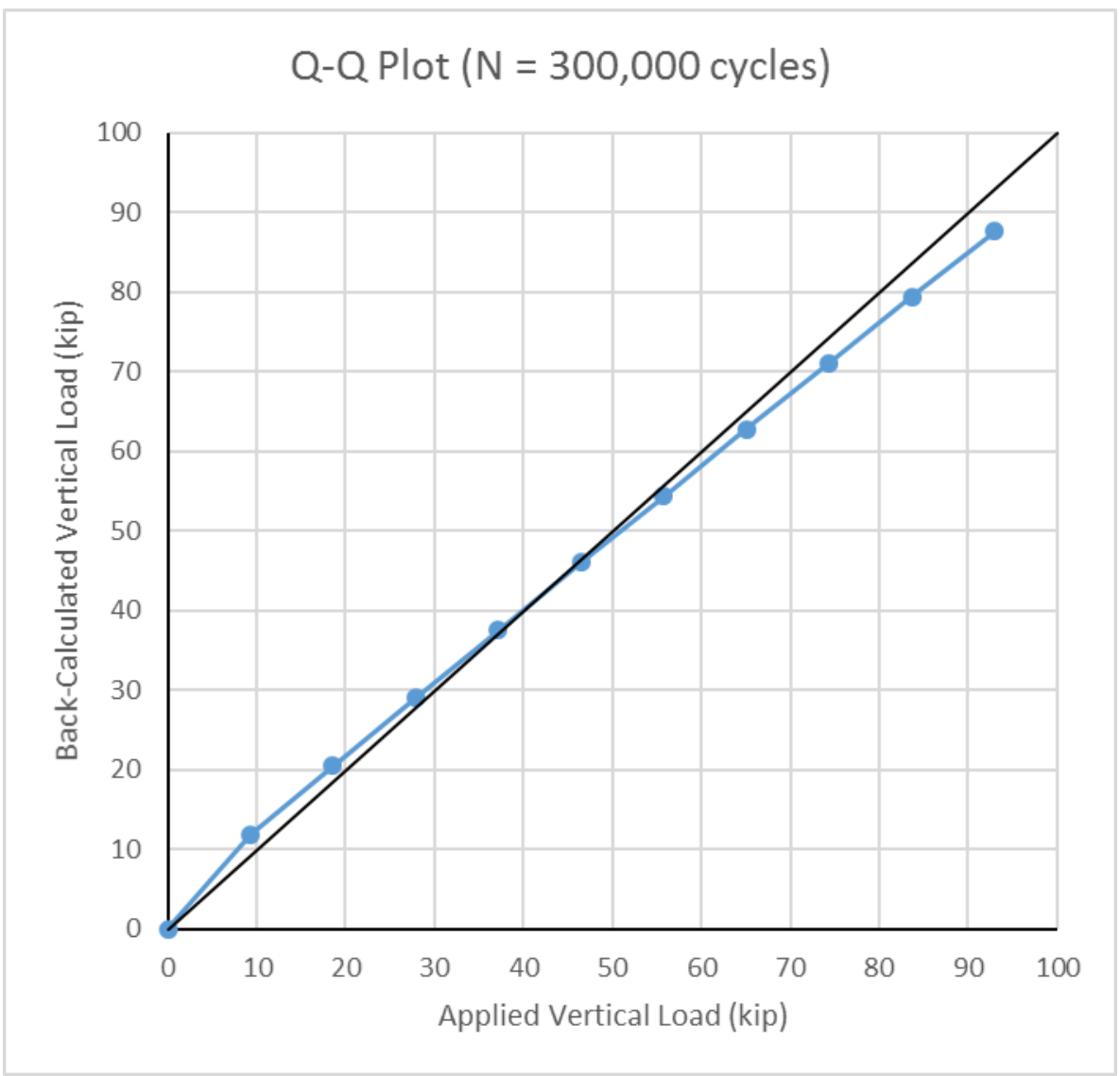

Figure 5.21: Experimental vs. Theoretical Loads at 300,000 Cycles 
Table 5.24: Load Test Summary at 500,000 Cycles

\begin{tabular}{|c|c|c|c|}
\hline $\begin{array}{c}|c| \\
\text { Load Test Summary (N=500,000) } \\
\text { Load, P (kip) }\end{array}$ & $\begin{array}{c}\text { Moment @ } \\
\text { Gage Loc. (ft-kip) }\end{array}$ & $\begin{array}{c}\text { Moment @ } \\
\text { Midspan (ft-kip) }\end{array}$ & $\begin{array}{c}\text { Back-Calc. } \\
\text { Appl. Load (kip) }\end{array}$ \\
\hline 0 & 0 & 0 & 0 \\
\hline 9.30 & 88.71 & 111.51 & 11.89 \\
\hline 18.60 & 154.18 & 193.81 & 20.67 \\
\hline 27.90 & 218.58 & 274.75 & 29.31 \\
\hline 37.20 & 281.96 & 354.42 & 37.80 \\
\hline 46.50 & 344.61 & 433.17 & 46.21 \\
\hline 55.80 & 407.49 & 512.20 & 54.64 \\
\hline 65.10 & 469.47 & 590.11 & 62.95 \\
\hline 74.40 & 531.78 & 668.44 & 71.30 \\
\hline 83.70 & 593.95 & 746.59 & 79.64 \\
\hline 93.00 & 655.85 & 824.39 & 87.93 \\
\hline
\end{tabular}

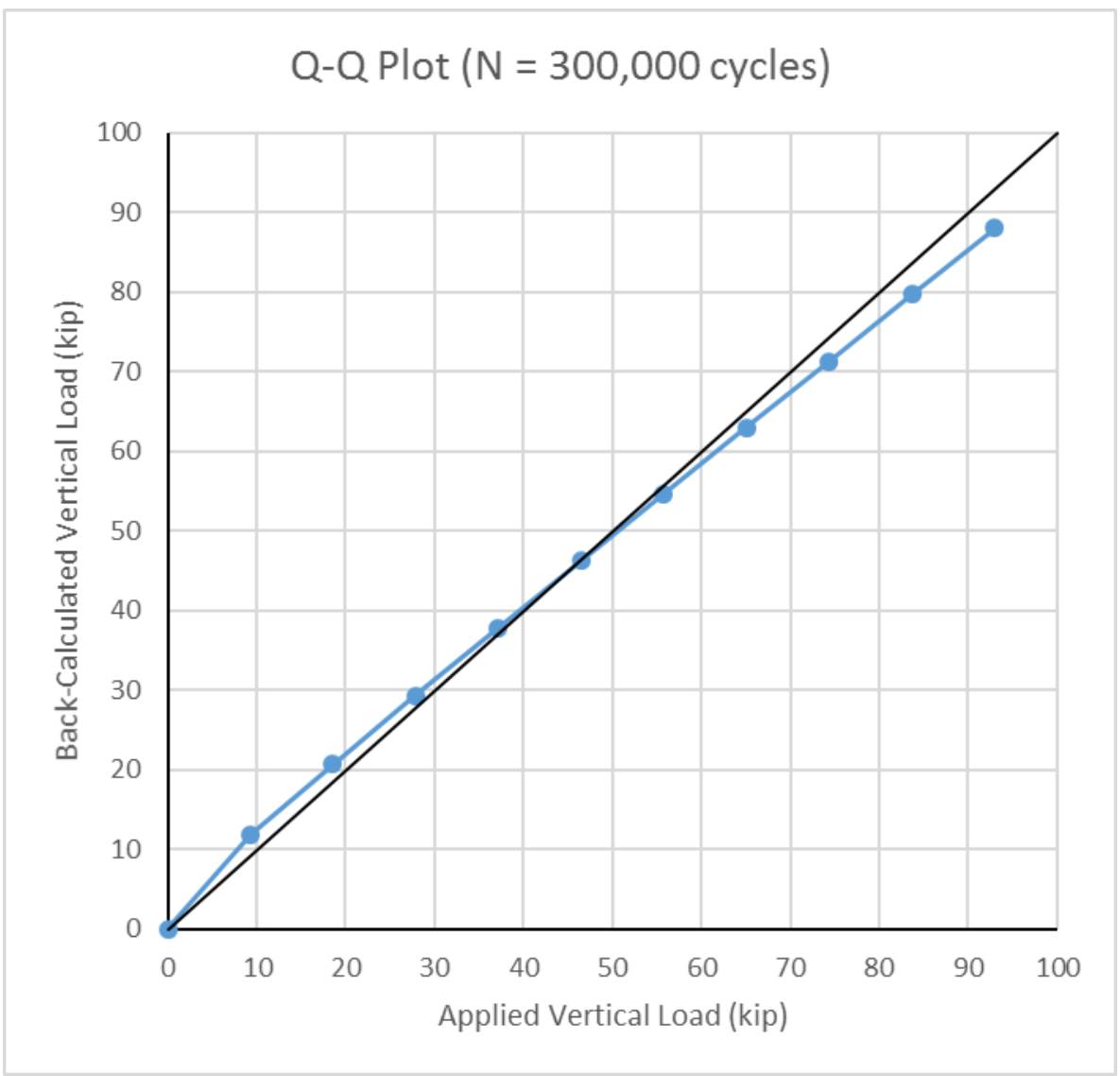

Figure 5.22: Experimental vs. Theoretical Loads at 500,000 Cycles 
Table 5.25: Load Test Summary at 700,000 Cycles

\begin{tabular}{|c|c|c|c|}
\hline $\begin{array}{c}\text { Load Test Summary (N=700,000) } \\
\text { Applied } \\
\text { Load, P (kip) }\end{array}$ & $\begin{array}{c}\text { Moment @ } \\
\text { Gage Loc. (ft-kip) }\end{array}$ & $\begin{array}{c}\text { Moment @ } \\
\text { Midspan (ft-kip) }\end{array}$ & $\begin{array}{c}\text { Back-Calc. } \\
\text { Appl. Load (kip) }\end{array}$ \\
\hline 0 & 0 & 0 & 0 \\
\hline 9.30 & 88.86 & 111.70 & 11.91 \\
\hline 18.60 & 153.27 & 192.66 & 20.55 \\
\hline 27.90 & 217.58 & 273.49 & 29.17 \\
\hline 37.20 & 281.37 & 353.67 & 37.73 \\
\hline 46.50 & 344.20 & 432.65 & 46.15 \\
\hline 55.80 & 406.46 & 510.92 & 54.50 \\
\hline 65.10 & 468.25 & 588.59 & 62.78 \\
\hline 74.40 & 529.60 & 665.70 & 71.01 \\
\hline 83.70 & 591.28 & 743.23 & 79.28 \\
\hline 93.00 & 652.80 & 820.56 & 87.53 \\
\hline
\end{tabular}

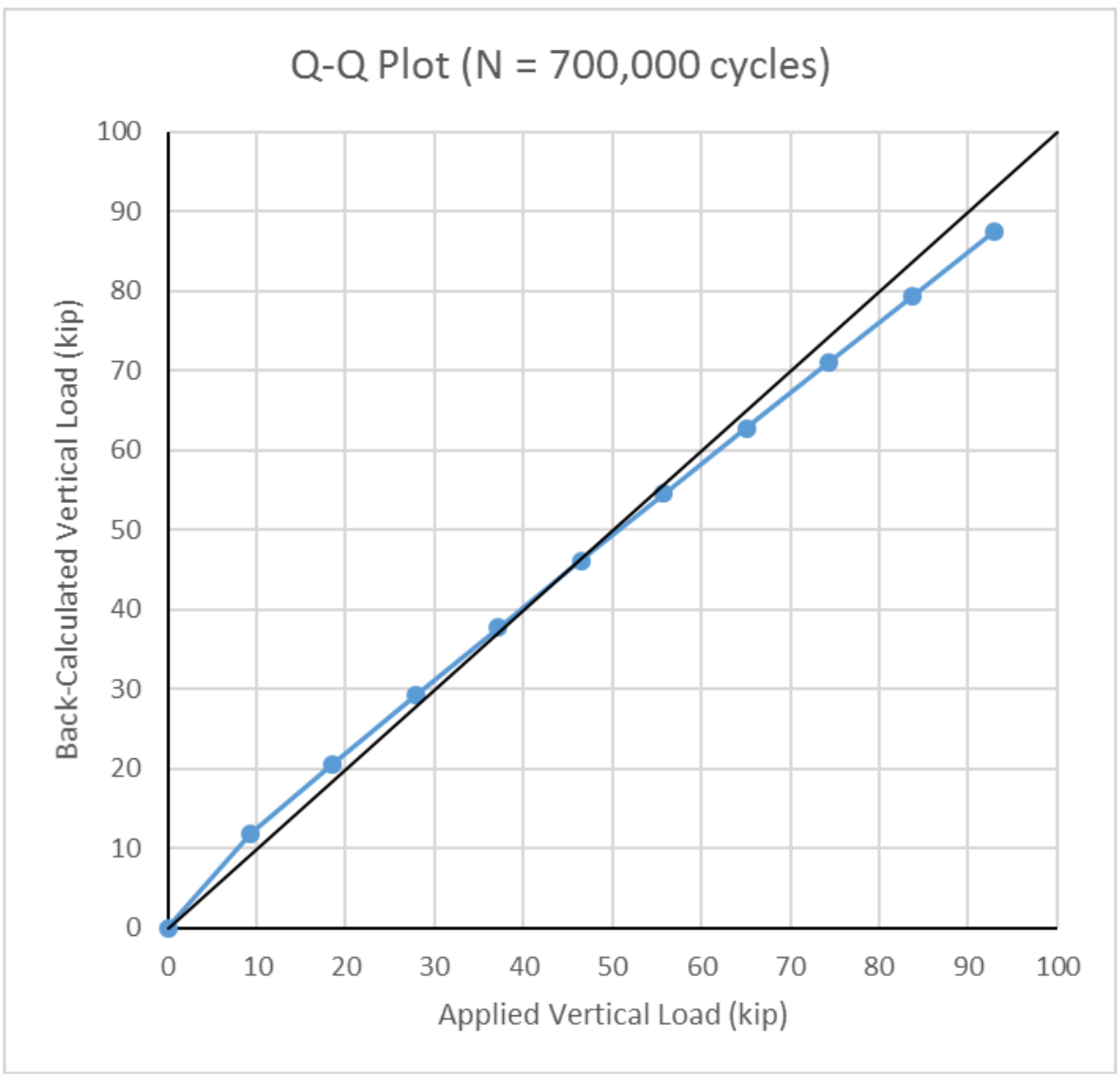

Figure 5.23: Experimental vs. Theoretical Loads at 700,000 Cycles 
Table 5.26: Load Test Summary at 900,000 Cycles

\begin{tabular}{|c|c|c|c|}
\hline $\begin{array}{c}|c| \\
\text { Load Test Summary (N=900,000) } \\
\text { Load, P (kip) }\end{array}$ & $\begin{array}{c}\text { Moment @ } \\
\text { Gage Loc. (ft-kip) }\end{array}$ & $\begin{array}{c}\text { Moment @ } \\
\text { Midspan (ft-kip) }\end{array}$ & $\begin{array}{c}\text { Back-Calc. } \\
\text { Appl. Load (kip) }\end{array}$ \\
\hline 0 & 0 & 0 & 0 \\
\hline 9.30 & 88.46 & 111.19 & 11.86 \\
\hline 18.60 & 152.89 & 192.18 & 20.50 \\
\hline 27.90 & 217.72 & 273.67 & 29.19 \\
\hline 37.20 & 280.76 & 352.92 & 37.64 \\
\hline 46.50 & 343.24 & 431.45 & 46.02 \\
\hline 55.80 & 404.93 & 508.99 & 54.29 \\
\hline 65.10 & 466.64 & 586.55 & 62.57 \\
\hline 74.40 & 528.36 & 664.15 & 70.84 \\
\hline 83.70 & 589.57 & 741.08 & 79.05 \\
\hline 93.00 & 650.19 & 817.28 & 87.18 \\
\hline
\end{tabular}

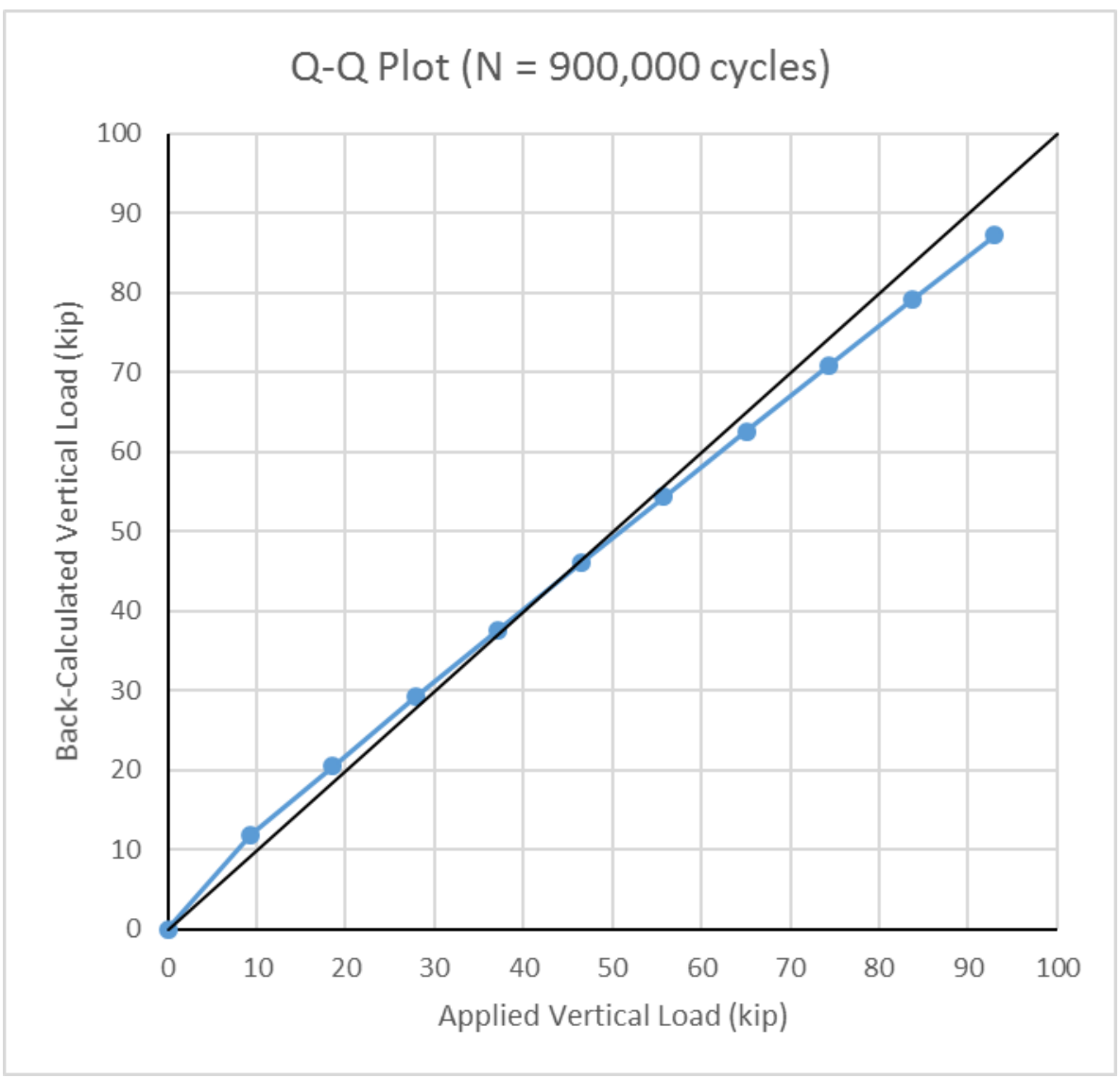

Figure 5.24: Experimental vs. Theoretical Loads at 900,000 Cycles 
Table 5.27: Load Test Summary at 1,100,000 Cycles

\begin{tabular}{|c|c|c|c|}
\hline $\begin{array}{c}\text { Load Test Summary (N=1,100,000) } \\
\text { Load, P (kip) }\end{array}$ & $\begin{array}{c}\text { Moment @ } \\
\text { Gage Loc. (ft-kip) }\end{array}$ & $\begin{array}{c}\text { Moment @ } \\
\text { Midspan (ft-kip) }\end{array}$ & $\begin{array}{c}\text { Back-Calc. } \\
\text { Appl. Load (kip) }\end{array}$ \\
\hline 0 & 0 & 0 & 0 \\
\hline 9.30 & 88.88 & 111.73 & 11.92 \\
\hline 18.60 & 153.57 & 193.03 & 20.59 \\
\hline 27.90 & 218.65 & 274.84 & 29.32 \\
\hline 37.20 & 282.11 & 354.61 & 37.82 \\
\hline 46.50 & 344.63 & 433.20 & 46.21 \\
\hline 55.80 & 406.59 & 511.08 & 54.52 \\
\hline 65.10 & 467.93 & 588.18 & 62.74 \\
\hline 74.40 & 529.07 & 665.03 & 70.94 \\
\hline 83.70 & 589.94 & 741.54 & 79.10 \\
\hline 93.00 & 650.74 & 817.97 & 87.25 \\
\hline
\end{tabular}

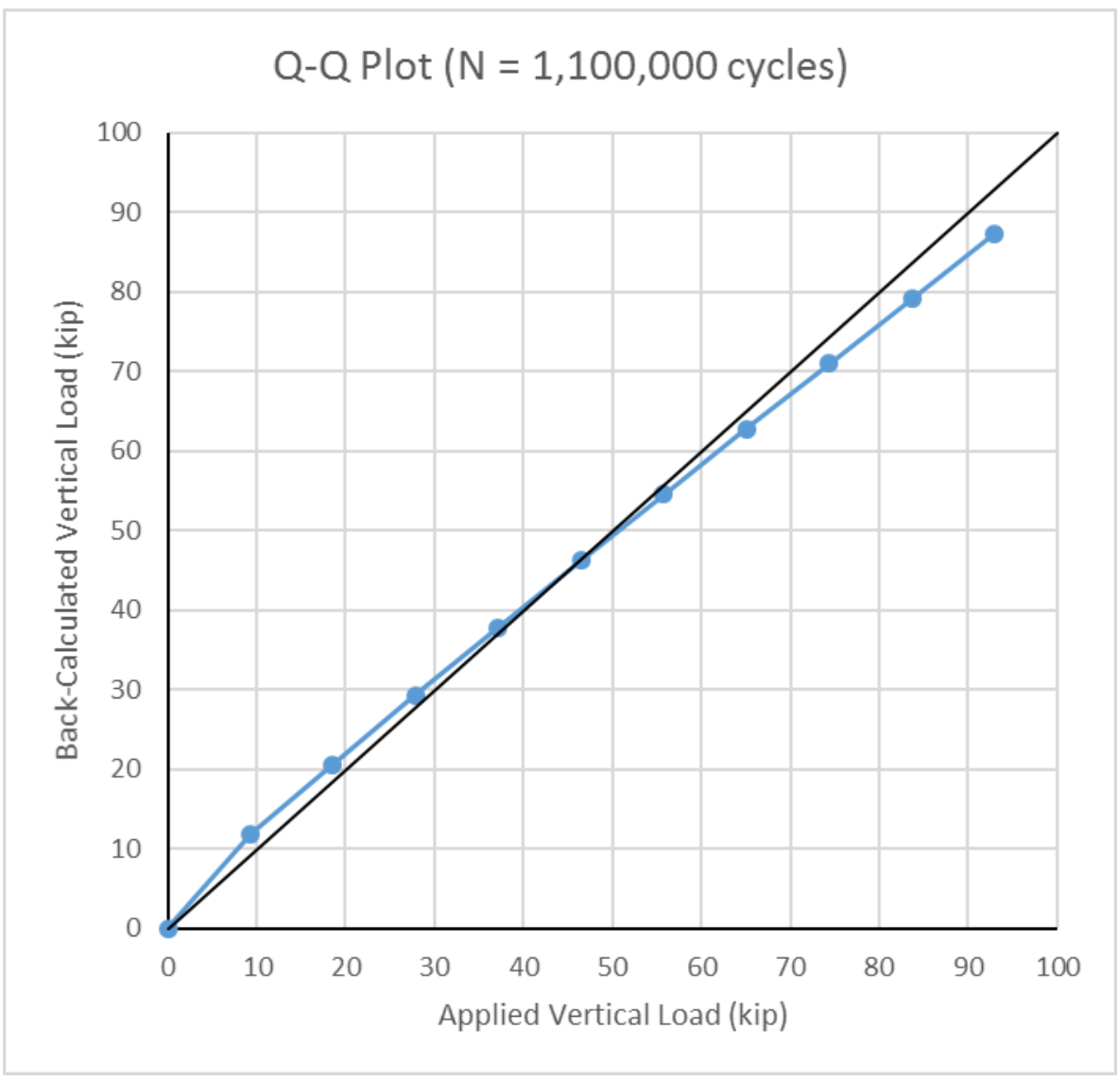

Figure 5.25: Experimental vs. Theoretical Loads at 1,100,000 Cycles 
Table 5.28: Load Test Summary at 1,300,000 Cycles

\begin{tabular}{|c|c|c|c|}
\hline $\begin{array}{c}|c| \\
\text { Applied } \\
\text { Load, P (kip) }\end{array}$ & $\begin{array}{c}\text { Moment @ } \\
\text { Gage Loc. (ft-kip) }\end{array}$ & $\begin{array}{c}\text { Moment @ } \\
\text { Midspan (ft-kip) }\end{array}$ & $\begin{array}{c}\text { Back-Calc. } \\
\text { Appl. Load (kip) }\end{array}$ \\
\hline 0 & 0 & 0 & 0 \\
\hline 9.30 & 89.51 & 112.52 & 12.00 \\
\hline 18.60 & 154.91 & 194.72 & 20.77 \\
\hline 27.90 & 220.36 & 276.99 & 29.55 \\
\hline 37.20 & 284.60 & 357.73 & 38.16 \\
\hline 46.50 & 347.74 & 437.11 & 46.62 \\
\hline 55.80 & 410.14 & 515.54 & 54.99 \\
\hline 65.10 & 472.48 & 593.90 & 63.35 \\
\hline 74.40 & 533.99 & 671.22 & 71.60 \\
\hline 83.70 & 595.74 & 748.84 & 79.88 \\
\hline 93.00 & 656.89 & 825.70 & 88.08 \\
\hline
\end{tabular}

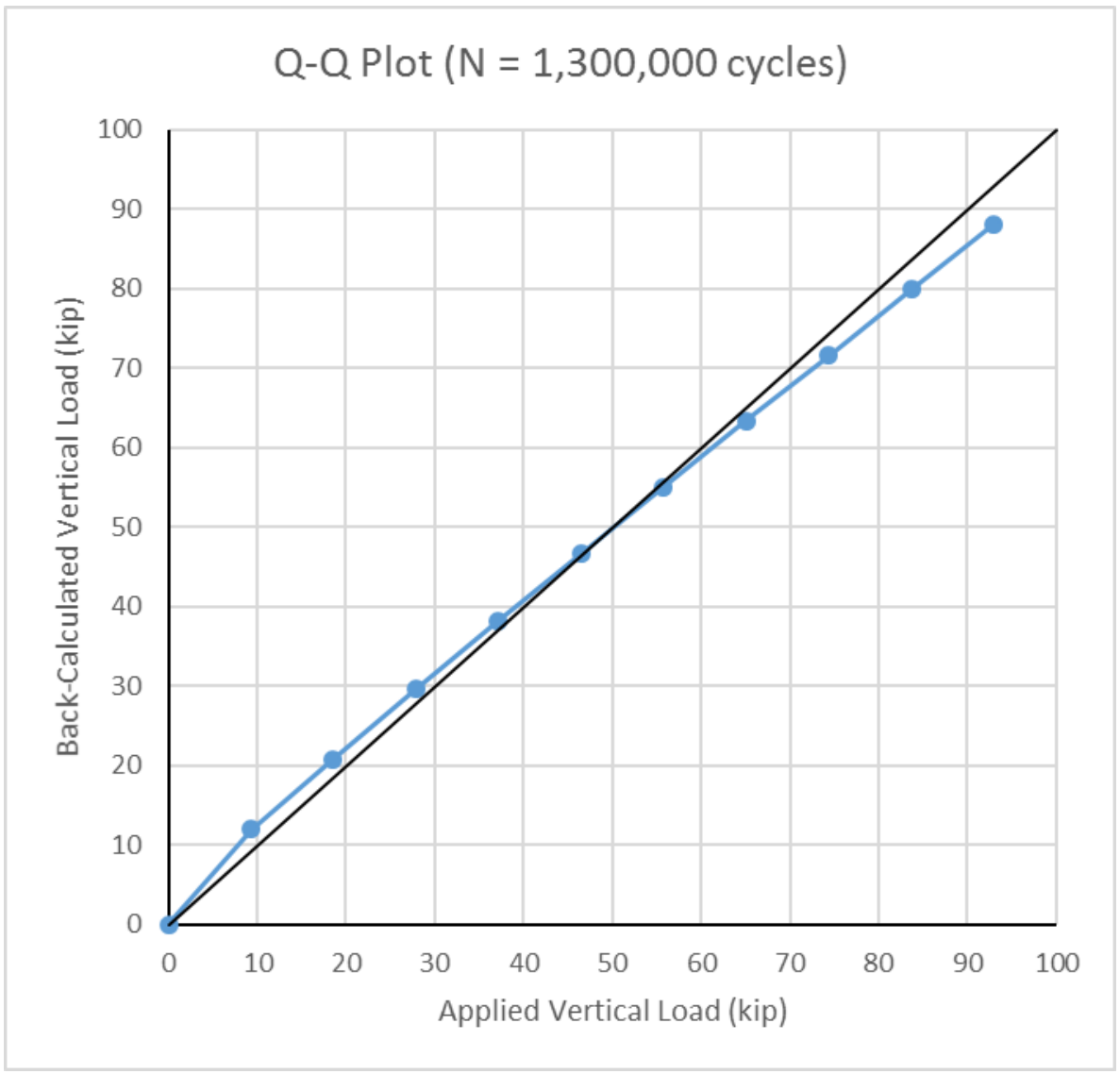

Figure 5.26: Experimental vs. Theoretical Loads at 1,300,000 Cycles 
Table 5.29: Load Test Summary at 1,500,000 Cycles

\begin{tabular}{|c|c|c|c|}
\hline $\begin{array}{c}\text { Load Test Summary (N=1,500,000) } \\
\text { Load, P (kip) }\end{array}$ & $\begin{array}{c}\text { Moment @ } \\
\text { Gage Loc. (ft-kip) }\end{array}$ & $\begin{array}{c}\text { Moment @ } \\
\text { Midspan (ft-kip) }\end{array}$ & $\begin{array}{c}\text { Back-Calc. } \\
\text { Appl. Load (kip) }\end{array}$ \\
\hline 0 & 0 & 0 & 0 \\
\hline 9.30 & 89.10 & 112.00 & 11.95 \\
\hline 18.60 & 154.73 & 194.50 & 20.75 \\
\hline 27.90 & 220.30 & 276.92 & 29.54 \\
\hline 37.20 & 284.71 & 357.88 & 38.17 \\
\hline 46.50 & 347.74 & 437.11 & 46.62 \\
\hline 55.80 & 410.38 & 515.85 & 55.02 \\
\hline 65.10 & 472.73 & 594.21 & 63.38 \\
\hline 74.40 & 534.72 & 672.14 & 71.69 \\
\hline 83.70 & 596.44 & 749.71 & 79.97 \\
\hline 93.00 & 658.21 & 827.36 & 88.25 \\
\hline
\end{tabular}

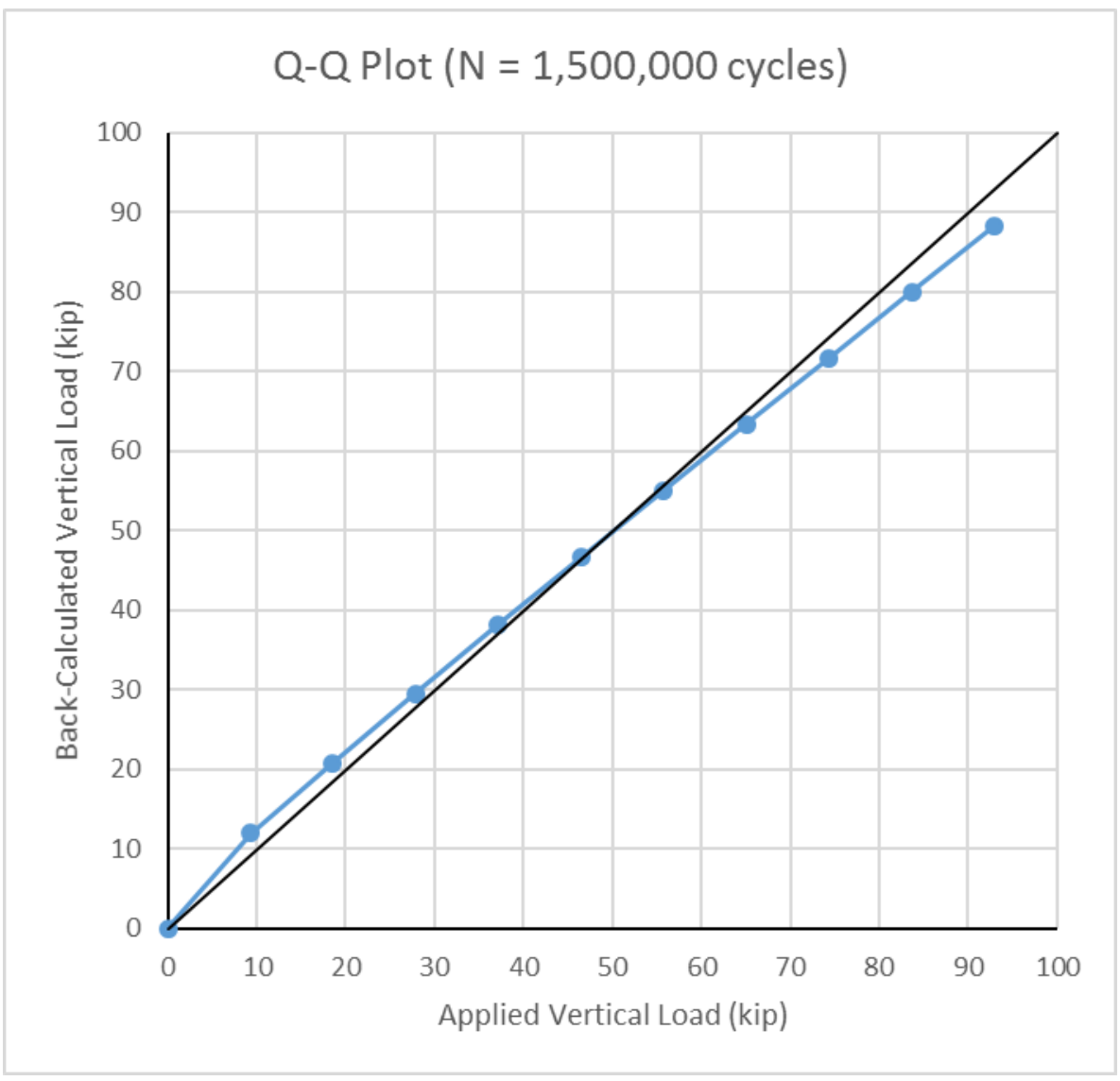

Figure 5.27: Experimental vs. Theoretical Loads at 1,500,000 Cycles 
Table 5.30: Load Test Summary at 1,700,000 Cycles

\begin{tabular}{|c|c|c|c|}
\hline $\begin{array}{c}\text { Load Test Summary (N=1,700,000) } \\
\text { Load, P (kip) }\end{array}$ & $\begin{array}{c}\text { Moment @ } \\
\text { Gage Loc. (ft-kip) }\end{array}$ & $\begin{array}{c}\text { Moment @ } \\
\text { Midspan (ft-kip) }\end{array}$ & $\begin{array}{c}\text { Back-Calc. } \\
\text { Appl. Load (kip) }\end{array}$ \\
\hline 0 & 0 & 0 & 0 \\
\hline 9.30 & 89.39 & 112.36 & 11.99 \\
\hline 18.60 & 154.79 & 194.57 & 20.75 \\
\hline 27.90 & 220.80 & 277.54 & 29.60 \\
\hline 37.20 & 285.32 & 358.64 & 38.25 \\
\hline 46.50 & 348.69 & 438.29 & 46.75 \\
\hline 55.80 & 411.38 & 517.10 & 55.16 \\
\hline 65.10 & 473.94 & 595.74 & 63.55 \\
\hline 74.40 & 535.58 & 673.22 & 71.81 \\
\hline 83.70 & 597.41 & 750.94 & 80.10 \\
\hline 93.00 & 659.03 & 828.39 & 88.36 \\
\hline
\end{tabular}

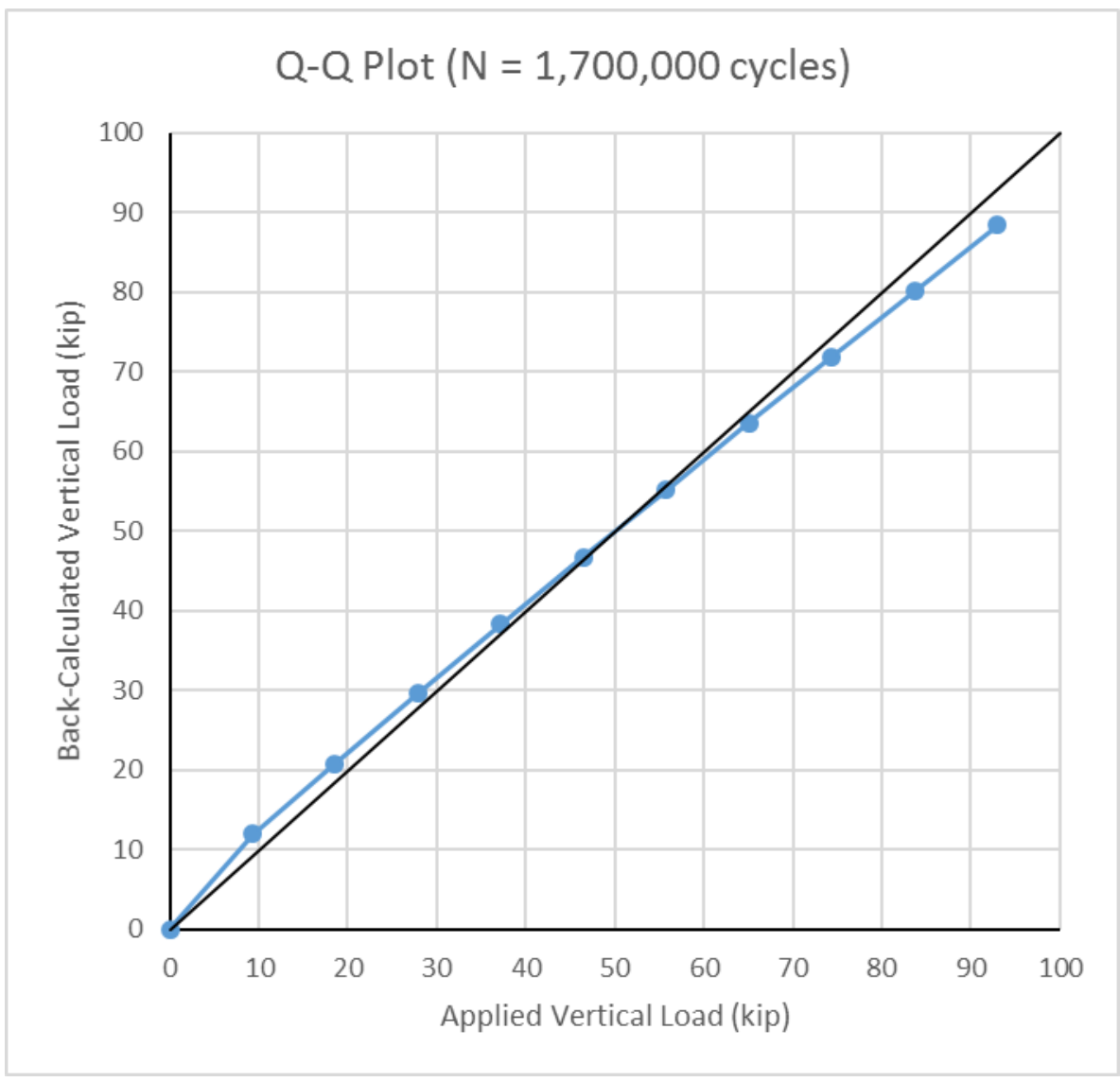

Figure 5.28: Experimental vs. Theoretical Loads at 1,700,000 Cycles 
Table 5.31: Load Test Summary at 1,900,000 Cycles

\begin{tabular}{|c|c|c|c|}
\hline $\begin{array}{c}\text { Load Test Summary (N=1,900,000) } \\
\text { Load, P (kip) }\end{array}$ & $\begin{array}{c}\text { Moment @ } \\
\text { Gage Loc. (ft-kip) }\end{array}$ & $\begin{array}{c}\text { Moment @ } \\
\text { Midspan (ft-kip) }\end{array}$ & $\begin{array}{c}\text { Back-Calc. } \\
\text { Appl. Load (kip) }\end{array}$ \\
\hline 0 & 0 & 0 & 0 \\
\hline 9.30 & 90.36 & 113.58 & 12.12 \\
\hline 18.60 & 157.05 & 197.41 & 21.06 \\
\hline 27.90 & 224.09 & 281.68 & 30.05 \\
\hline 37.20 & 289.27 & 363.61 & 38.79 \\
\hline 46.50 & 352.96 & 443.67 & 47.32 \\
\hline 55.80 & 415.76 & 522.61 & 55.74 \\
\hline 65.10 & 477.99 & 600.82 & 64.09 \\
\hline 74.40 & 539.70 & 678.39 & 72.36 \\
\hline 83.70 & 601.53 & 756.11 & 80.65 \\
\hline 93.00 & 662.87 & 833.21 & 88.88 \\
\hline
\end{tabular}

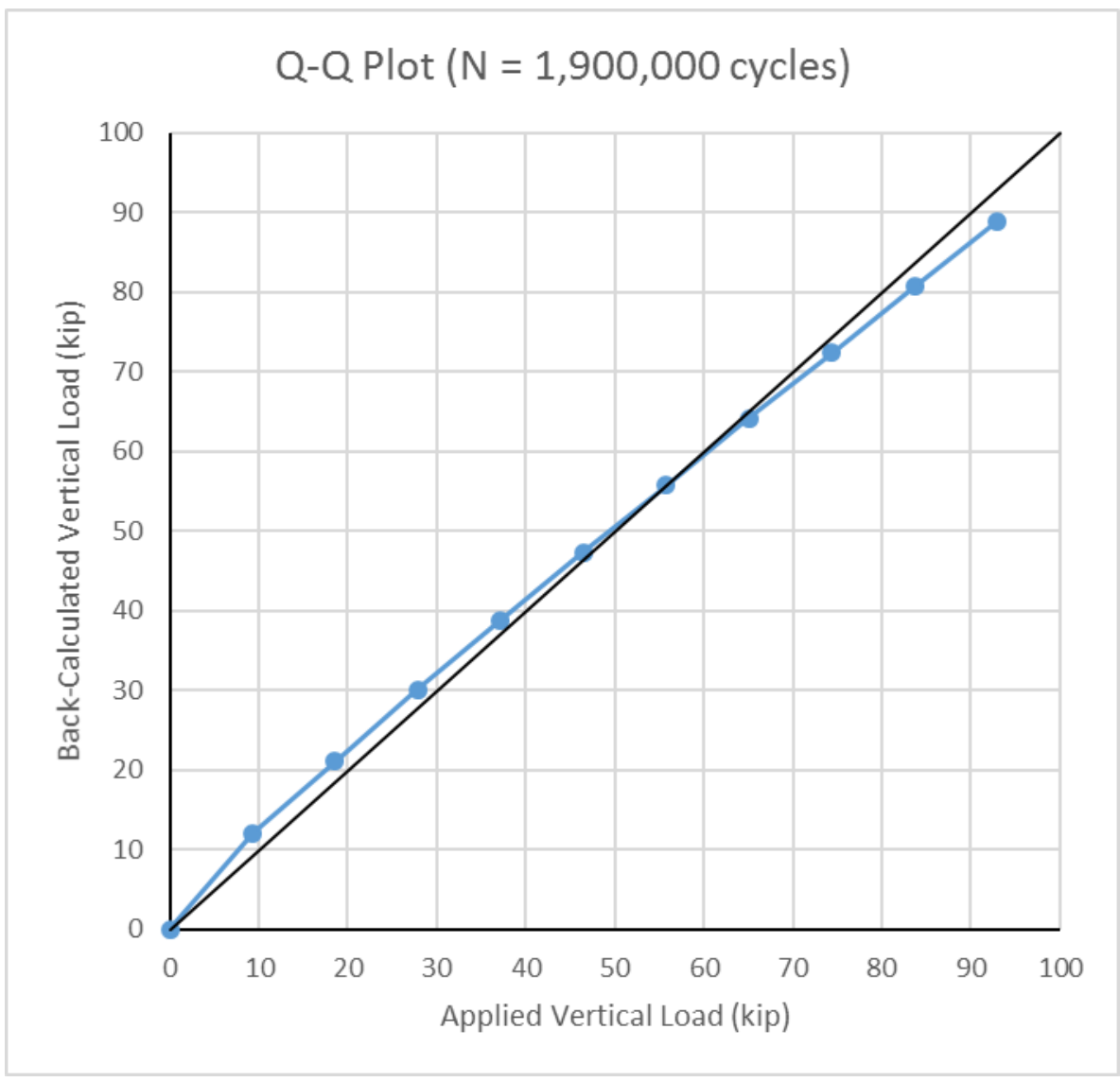

Figure 5.29: Experimental vs. Theoretical Loads at 1,900,000 Cycles 
Table 5.32: Load Test Summary at 2,100,000 Cycles

\begin{tabular}{|c|c|c|c|}
\hline $\begin{array}{c}\text { Load Test Summary (N=2,100,000) } \\
\text { Load, P (kip) }\end{array}$ & $\begin{array}{c}\text { Moment @ } \\
\text { Gage Loc. (ft-kip) }\end{array}$ & $\begin{array}{c}\text { Moment @ } \\
\text { Midspan (ft-kip) }\end{array}$ & $\begin{array}{c}\text { Back-Calc. } \\
\text { Appl. Load (kip) }\end{array}$ \\
\hline 0 & 0 & 0 & 0 \\
\hline 9.30 & 89.91 & 113.01 & 12.05 \\
\hline 18.60 & 156.43 & 196.63 & 20.97 \\
\hline 27.90 & 223.66 & 281.14 & 29.99 \\
\hline 37.20 & 289.34 & 363.69 & 38.79 \\
\hline 46.50 & 353.11 & 443.85 & 47.34 \\
\hline 55.80 & 415.88 & 522.76 & 55.76 \\
\hline 65.10 & 478.20 & 601.09 & 64.12 \\
\hline 74.40 & 539.67 & 678.36 & 72.36 \\
\hline 83.70 & 601.45 & 756.01 & 80.64 \\
\hline 93.00 & 662.83 & 833.17 & 88.87 \\
\hline
\end{tabular}

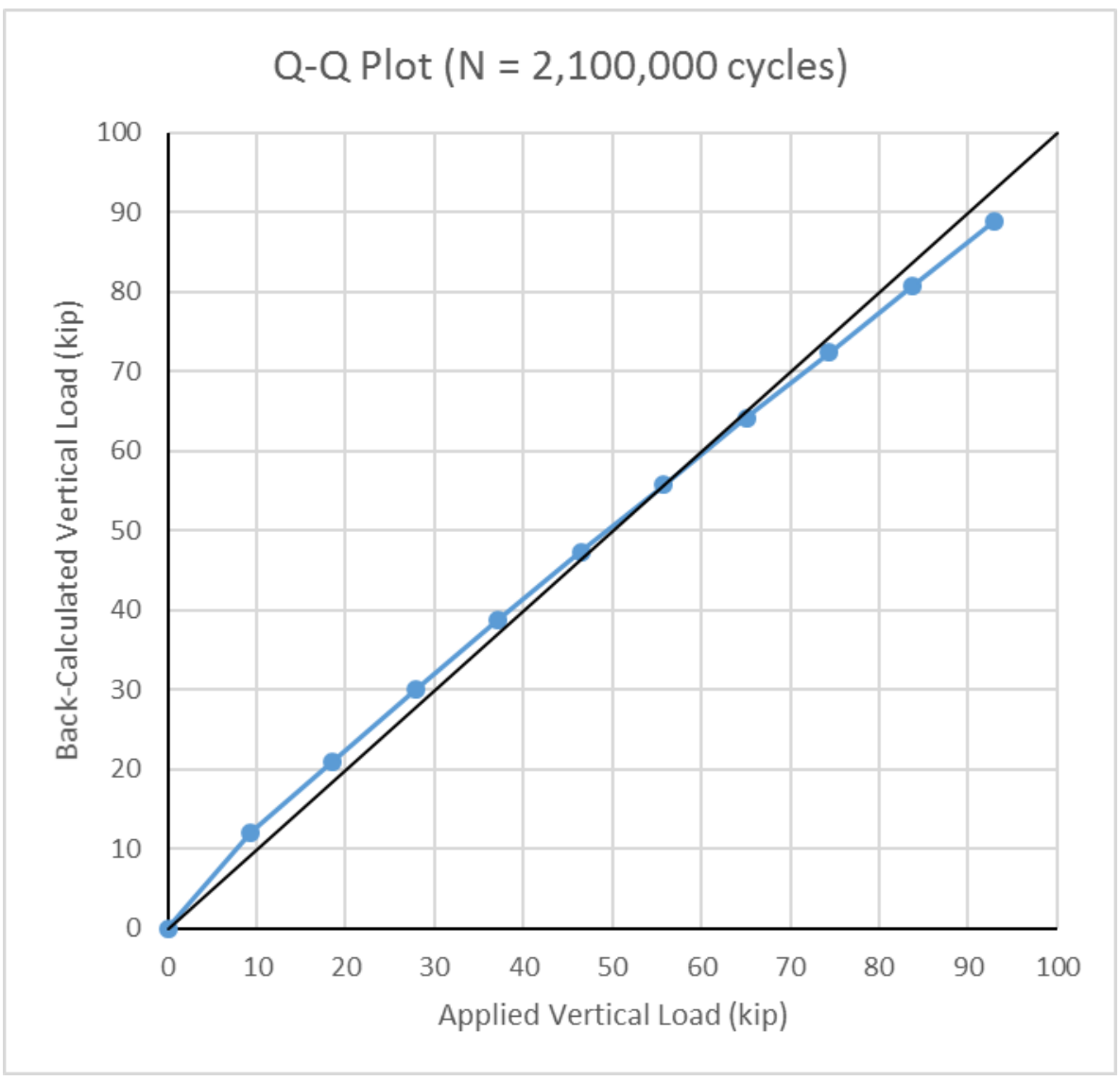

Figure 5.30: Experimental vs. Theoretical Loads at 2,100,000 Cycles 
Table 5.33: Load Test Summary at 2,300,000 Cycles

\begin{tabular}{|c|c|c|c|}
\hline $\begin{array}{c}|c| \\
\text { Applied } \\
\text { Load, P (kip) }\end{array}$ & $\begin{array}{c}\text { Moment @ } \\
\text { Gage Loc. (ft-kip) }\end{array}$ & $\begin{array}{c}\text { Moment @ } \\
\text { Midspan (ft-kip) }\end{array}$ & $\begin{array}{c}\text { Back-Calc. } \\
\text { Appl. Load (kip) }\end{array}$ \\
\hline 0 & 0 & 0 & 0 \\
\hline 9.30 & 89.22 & 112.15 & 11.96 \\
\hline 18.60 & 154.16 & 193.77 & 20.67 \\
\hline 27.90 & 219.39 & 275.77 & 29.42 \\
\hline 37.20 & 284.76 & 357.93 & 38.18 \\
\hline 46.50 & 349.43 & 439.22 & 46.85 \\
\hline 55.80 & 413.60 & 519.88 & 55.45 \\
\hline 65.10 & 477.85 & 600.65 & 64.07 \\
\hline 74.40 & 541.84 & 681.08 & 72.65 \\
\hline 83.70 & 605.58 & 761.21 & 81.20 \\
\hline 93.00 & 669.66 & 841.76 & 89.79 \\
\hline
\end{tabular}

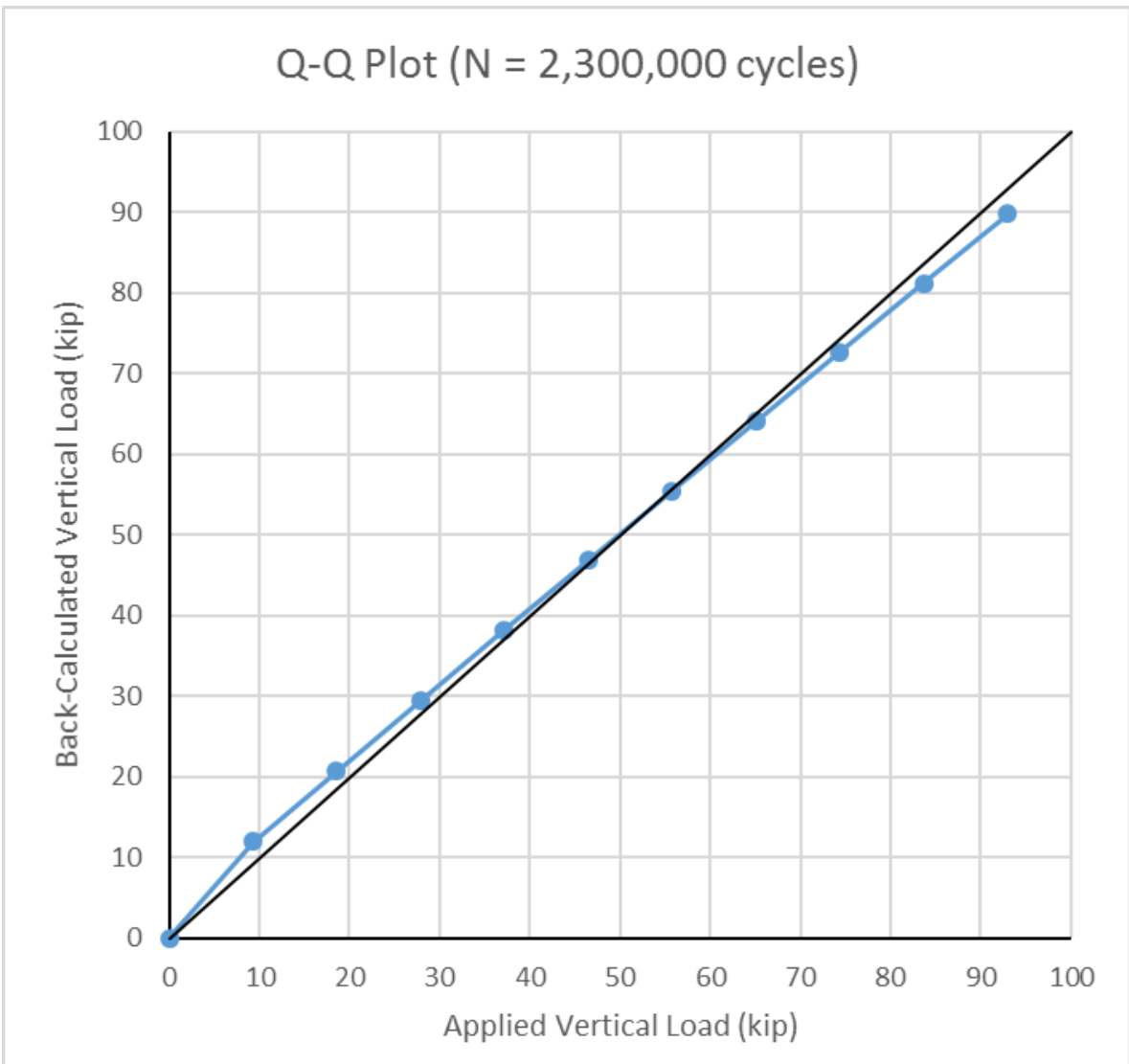

Figure 5.31: Experimental vs. Theoretical Loads at 2,300,000 Cycles 
Table 5.34: Load Test Summary at 2,500,000 Cycles

\begin{tabular}{|c|c|c|c|}
\hline $\begin{array}{c}|c| \\
\text { Applied } \\
\text { Load, P (kip) }\end{array}$ & $\begin{array}{c}\text { Moment @ } \\
\text { Gage Loc. (ft-kip) }\end{array}$ & $\begin{array}{c}\text { Moment @ } \\
\text { Midspan (ft-kip) }\end{array}$ & $\begin{array}{c}\text { Back-Calc. } \\
\text { Appl. Load (kip) }\end{array}$ \\
\hline 0 & 0 & 0 & 0 \\
\hline 9.30 & 89.19 & 112.11 & 11.96 \\
\hline 18.60 & 154.14 & 193.75 & 20.67 \\
\hline 27.90 & 220.17 & 276.75 & 29.52 \\
\hline 37.20 & 285.47 & 358.83 & 38.27 \\
\hline 46.50 & 350.26 & 440.27 & 46.96 \\
\hline 55.80 & 418.23 & 525.71 & 56.08 \\
\hline 65.10 & 479.58 & 602.83 & 64.30 \\
\hline 74.40 & 543.49 & 683.16 & 72.87 \\
\hline 83.70 & 607.83 & 764.04 & 81.50 \\
\hline 93.00 & 671.84 & 844.49 & 90.08 \\
\hline
\end{tabular}

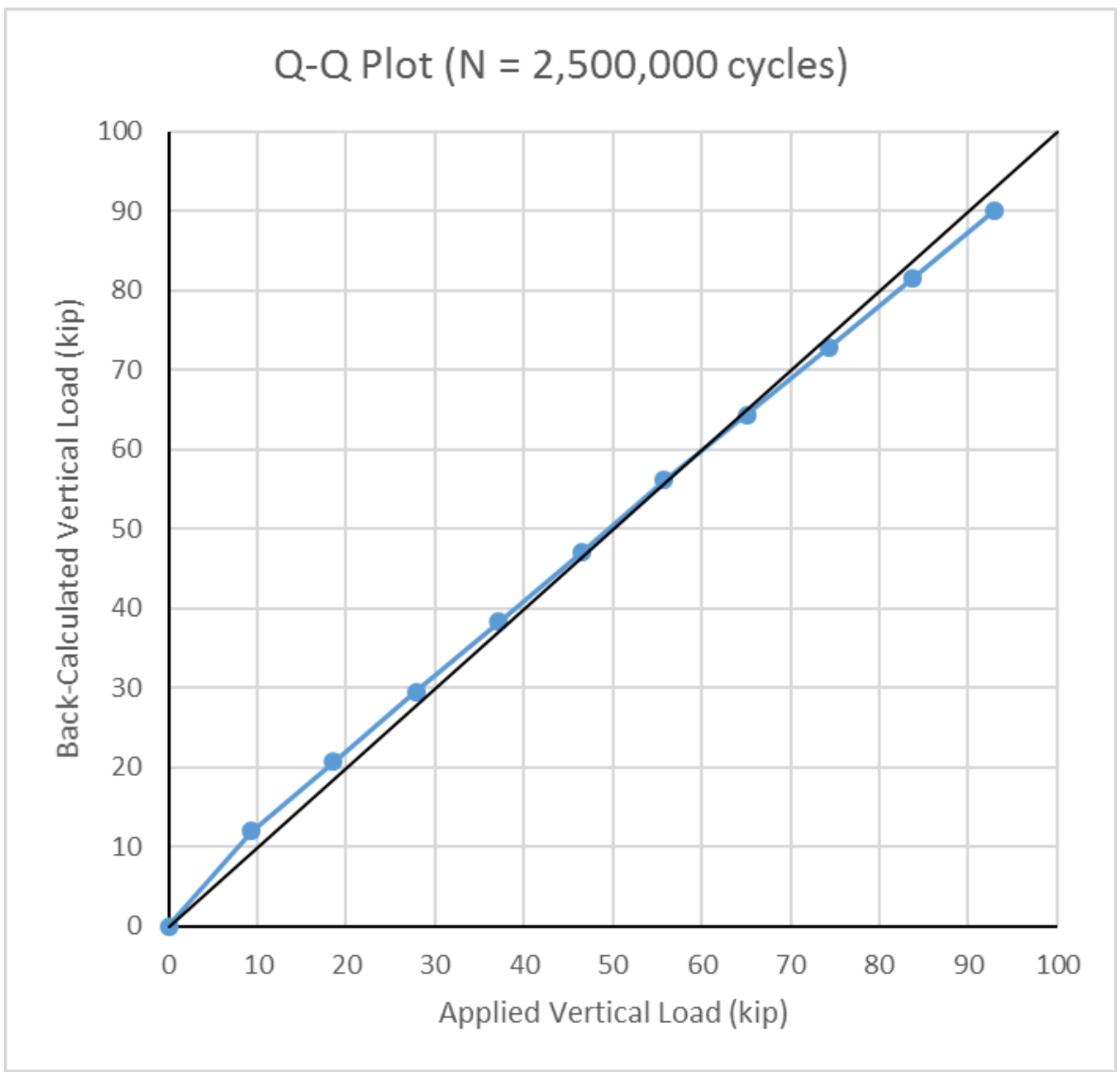

Figure 5.32: Experimental vs. Theoretical Loads at 2,500,000 Cycles 
Table 5.35: Load Test Summary at 2,700,000 Cycles

\begin{tabular}{|c|c|c|c|}
\hline $\begin{array}{c}\text { Load Test Summary (N=2,700,000) } \\
\text { Applied } \\
\text { Load, P (kip) }\end{array}$ & $\begin{array}{c}\text { Moment @ } \\
\text { Gage Loc. (ft-kip) }\end{array}$ & $\begin{array}{c}\text { Moment @ } \\
\text { Midspan (ft-kip) }\end{array}$ & $\begin{array}{c}\text { Back-Calc. } \\
\text { Appl. Load (kip) }\end{array}$ \\
\hline 0 & 0 & 0 & 0 \\
\hline 9.30 & 89.10 & 112.00 & 11.95 \\
\hline 18.60 & 153.71 & 193.21 & 20.61 \\
\hline 27.90 & 219.40 & 275.78 & 29.42 \\
\hline 37.20 & 284.52 & 357.64 & 38.15 \\
\hline 46.50 & 349.50 & 439.31 & 46.86 \\
\hline 55.80 & 414.05 & 520.46 & 55.52 \\
\hline 65.10 & 478.40 & 601.34 & 64.14 \\
\hline 74.40 & 542.47 & 681.88 & 72.73 \\
\hline 83.70 & 606.70 & 762.61 & 81.35 \\
\hline 93.00 & 670.03 & 842.22 & 89.84 \\
\hline
\end{tabular}

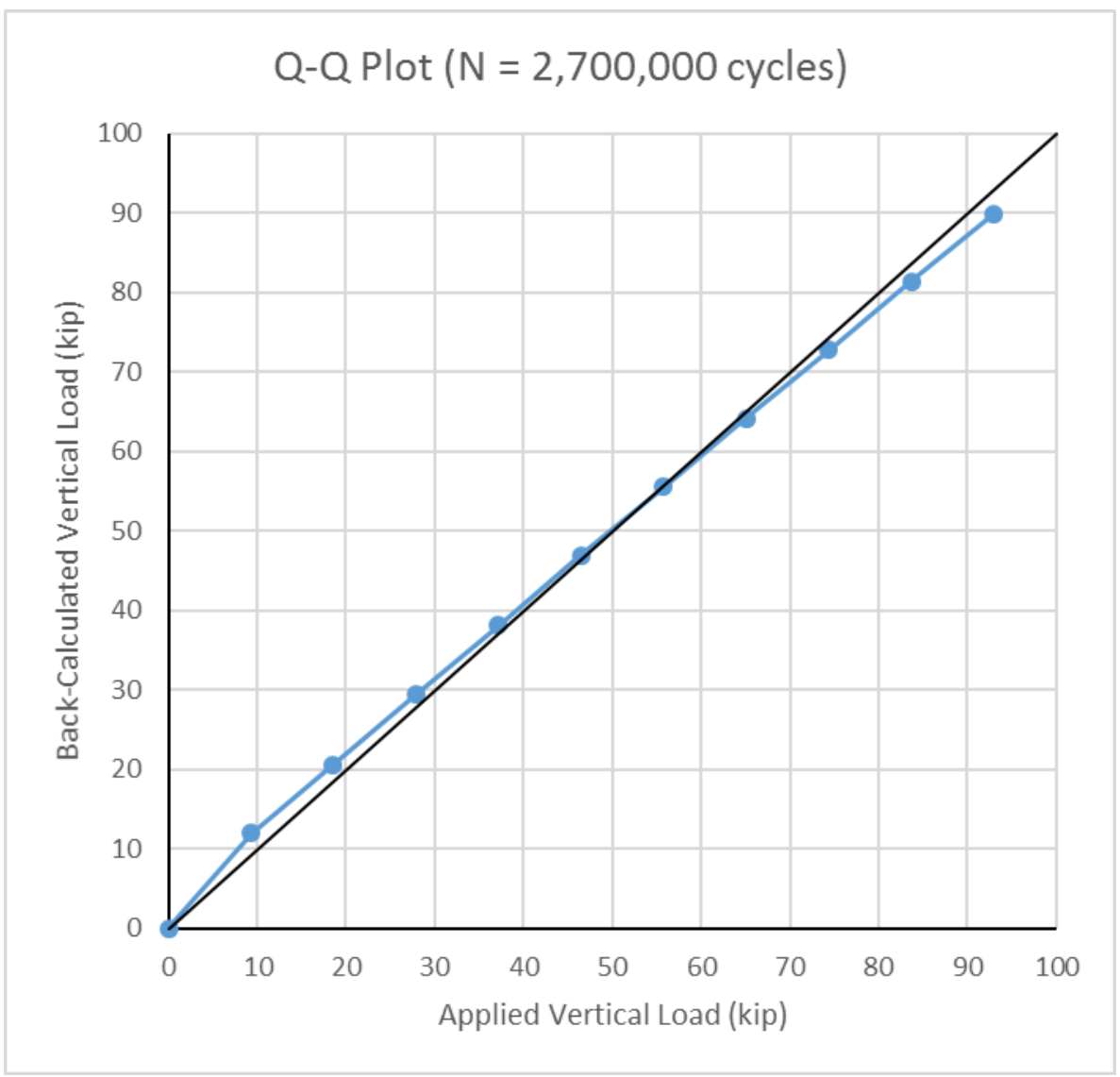

Figure 5.33: Experimental vs. Theoretical Loads at 2,700,000 Cycles 
Table 5.36: Load Test Summary at 2,900,000 Cycles

\begin{tabular}{|c|c|c|c|}
\hline $\begin{array}{c}|c| \\
\text { Applied } \\
\text { Load, P (kip) }\end{array}$ & $\begin{array}{c}\text { Moment @ } \\
\text { Gage Loc. (ft-kip) }\end{array}$ & $\begin{array}{c}\text { Moment @ } \\
\text { Midspan (ft-kip) }\end{array}$ & $\begin{array}{c}\text { Back-Calc. } \\
\text { Appl. Load (kip) }\end{array}$ \\
\hline 0 & 0 & 0 & 0 \\
\hline 9.30 & 88.81 & 111.63 & 11.91 \\
\hline 18.60 & 154.19 & 193.82 & 20.67 \\
\hline 27.90 & 219.55 & 275.97 & 29.44 \\
\hline 37.20 & 284.78 & 357.96 & 38.18 \\
\hline 46.50 & 349.61 & 439.45 & 46.87 \\
\hline 55.80 & 414.12 & 520.54 & 55.52 \\
\hline 65.10 & 478.35 & 601.28 & 64.14 \\
\hline 74.40 & 542.66 & 682.11 & 72.76 \\
\hline 83.70 & 606.66 & 762.56 & 81.34 \\
\hline 93.00 & 670.68 & 843.03 & 89.92 \\
\hline
\end{tabular}

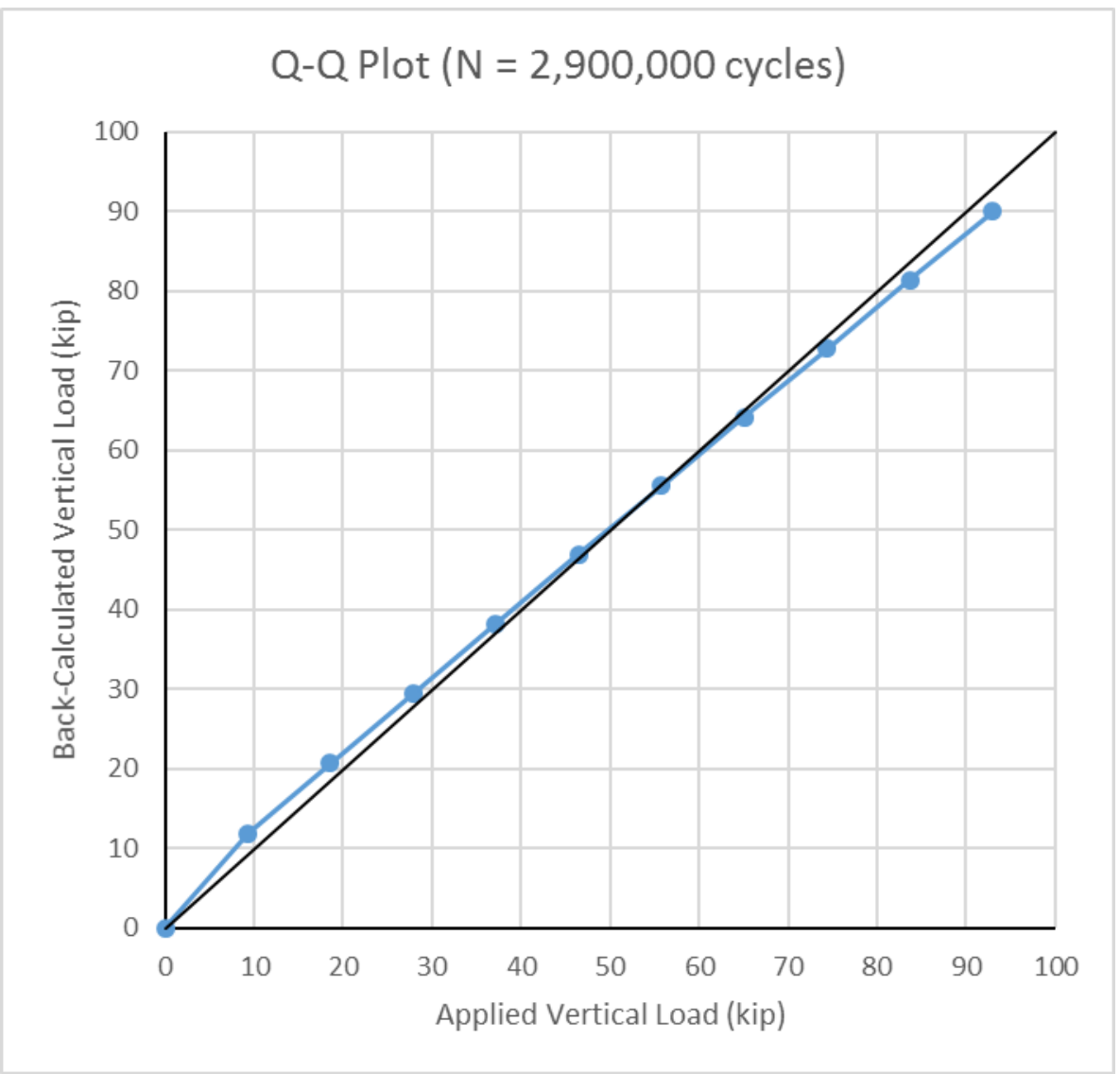

Figure 5.34: Experimental vs. Theoretical Loads at 2,900,000 Cycles 


\subsection{DEFLECTIONS}

LVDTs measured vertical deflections at 92.50 kip for the uncoated steel specimen and 93.00 kip for the galvanized steel specimen. The LVDTs were placed at quarter points of each of the specimens. As seen in Tables 5.37 and 5.38, the deflection values remained nearly uniform throughout the entirety of the testing. The deflections of the galvanized steel specimen are larger than the those of the uncoated steel specimen, which can be attributed to weaker concrete in the deck of the galvanized specimen.

Table 5.37: Summary of Uncoated Steel Specimen Deflections

\begin{tabular}{|c|c|c|c|}
\hline \multirow{2}{*}{$\begin{array}{c}\text { Cycle } \\
\text { Count }\end{array}$} & \multicolumn{3}{|c|}{ Deflection at 92.50 kip (in) } \\
\cline { 2 - 4 } & Q1 & Q2 & Q3 \\
\hline 0 & 0.536 & 0.809 & 0.568 \\
\hline 100,000 & 0.549 & 0.828 & 0.581 \\
\hline 200,000 & 0.556 & 0.837 & 0.586 \\
\hline 300,000 & 0.555 & 0.836 & 0.587 \\
\hline 500,000 & 0.565 & 0.850 & 0.596 \\
\hline 700,000 & 0.591 & 0.877 & 0.611 \\
\hline 900,000 & 0.596 & 0.885 & 0.615 \\
\hline $1,100,000$ & 0.609 & 0.903 & 0.629 \\
\hline $1,300,000$ & 0.617 & 0.917 & 0.637 \\
\hline $1,500,000$ & 0.615 & 0.913 & 0.635 \\
\hline $1,700,000$ & 0.619 & 0.918 & 0.637 \\
\hline $1,900,000$ & 0.633 & 0.939 & 0.650 \\
\hline $2,100,000$ & 0.637 & 0.945 & 0.655 \\
\hline $2,300,000$ & 0.637 & 0.945 & 0.652 \\
\hline $2,500,000$ & 0.642 & 0.951 & 0.655 \\
\hline $2,700,000$ & 0.649 & 0.962 & 0.663 \\
\hline $2,900,000$ & 0.658 & 0.974 & 0.674 \\
\hline
\end{tabular}


Table 5.38: Summary of Galvanized Steel Specimen Deflections

\begin{tabular}{|c|c|c|c|}
\hline \multirow{2}{*}{ Cycle Count } & \multicolumn{3}{|c|}{ Deflection at 93.00 kip (in) } \\
\cline { 2 - 4 } & Q1 & Q2 & Q3 \\
\hline 0 & 0.621 & 0.920 & 0.619 \\
\hline 100,000 & 0.639 & 0.951 & 0.637 \\
\hline 200,000 & 0.657 & 0.973 & 0.651 \\
\hline 300,000 & 0.672 & 0.994 & \\
\hline 500,000 & 0.692 & 0.994 & 0.685 \\
\hline 700,000 & 0.714 & 1.053 & 0.711 \\
\hline 900,000 & 0.730 & 1.074 & 0.729 \\
\hline $1,100,000$ & 0.743 & 1.095 & 0.744 \\
\hline $1,300,000$ & 0.759 & 1.116 & 0.760 \\
\hline $1,500,000$ & 0.760 & 1.127 & 0.767 \\
\hline $1,700,000$ & 0.779 & 1.144 & 0.775 \\
\hline $1,900,000$ & 0.793 & 1.164 & 0.789 \\
\hline $2,100,000$ & 0.799 & 1.171 & 0.793 \\
\hline $2,300,000$ & 0.803 & 1.178 & 0.797 \\
\hline $2,500,000$ & 0.811 & 1.188 & 0.804 \\
\hline $2,700,000$ & & 1.201 & 0.814 \\
\hline $2,900,000$ & 0.824 & 1.208 & 0.820 \\
\hline
\end{tabular}

\subsection{Test to Failure Results}

The midspan load-deflection results for the uncoated steel specimen are shown in Figure 5.35. The LVDTs were removed from the testing after the specimen had deflected approximately 3.5 inches as the range the LVDTs could accurately measure had been exceeded. The strain-load relationship is shown in Figure 5.36. The load strain results show the ultimate load the specimen can hold before composite action is lost. After the loss of composite action, any additional load introduced into the system will cause increased deflection without increased load resistance. If the loading of the specimen would have been in load control instead of stroke control, there would have been a sudden and catastrophic failure of the system. The test to failure of the galvanized steel specimen is not included in this thesis due to time constraints. The collected data and analysis shall be included in a future paper synthesized from work performed in this thesis and the results from the flexural testing of the galvanized steel specimen. 


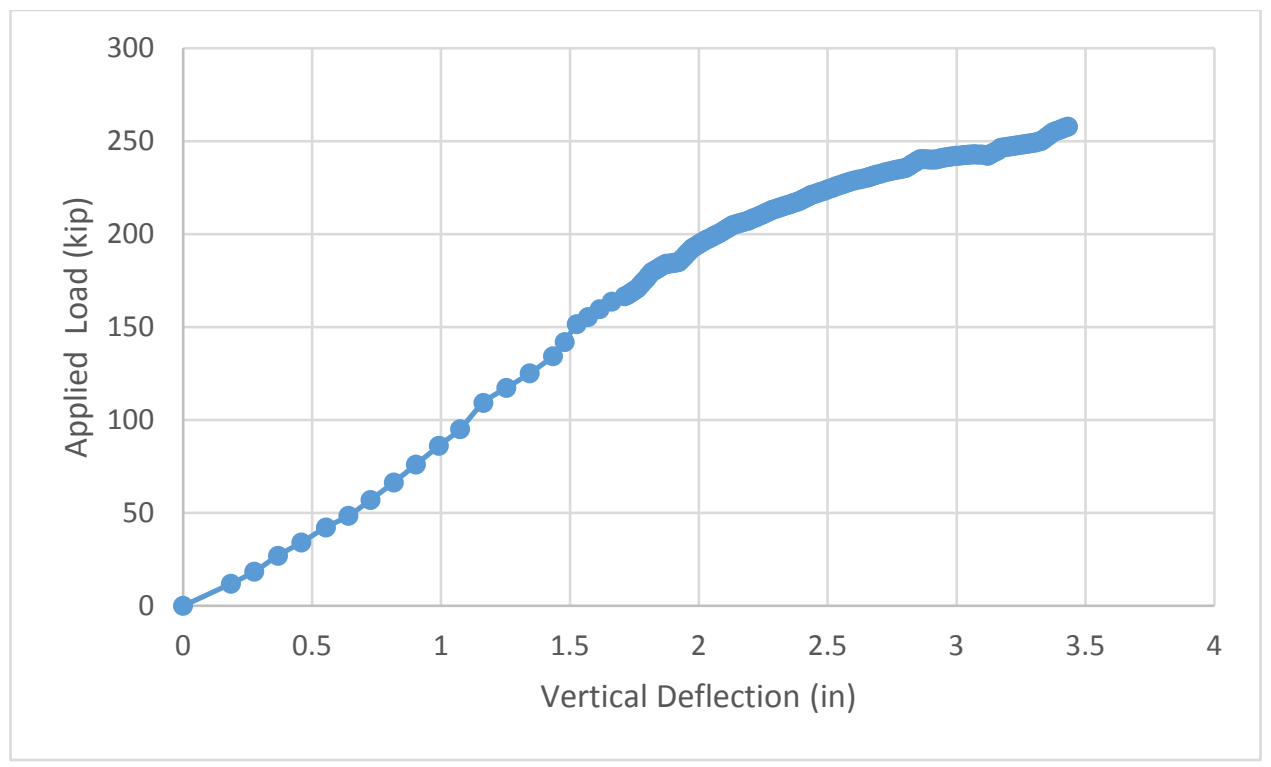

Figure 5.35: Load-Deflection Data from Flexural Testing of Uncoated Steel Specimen

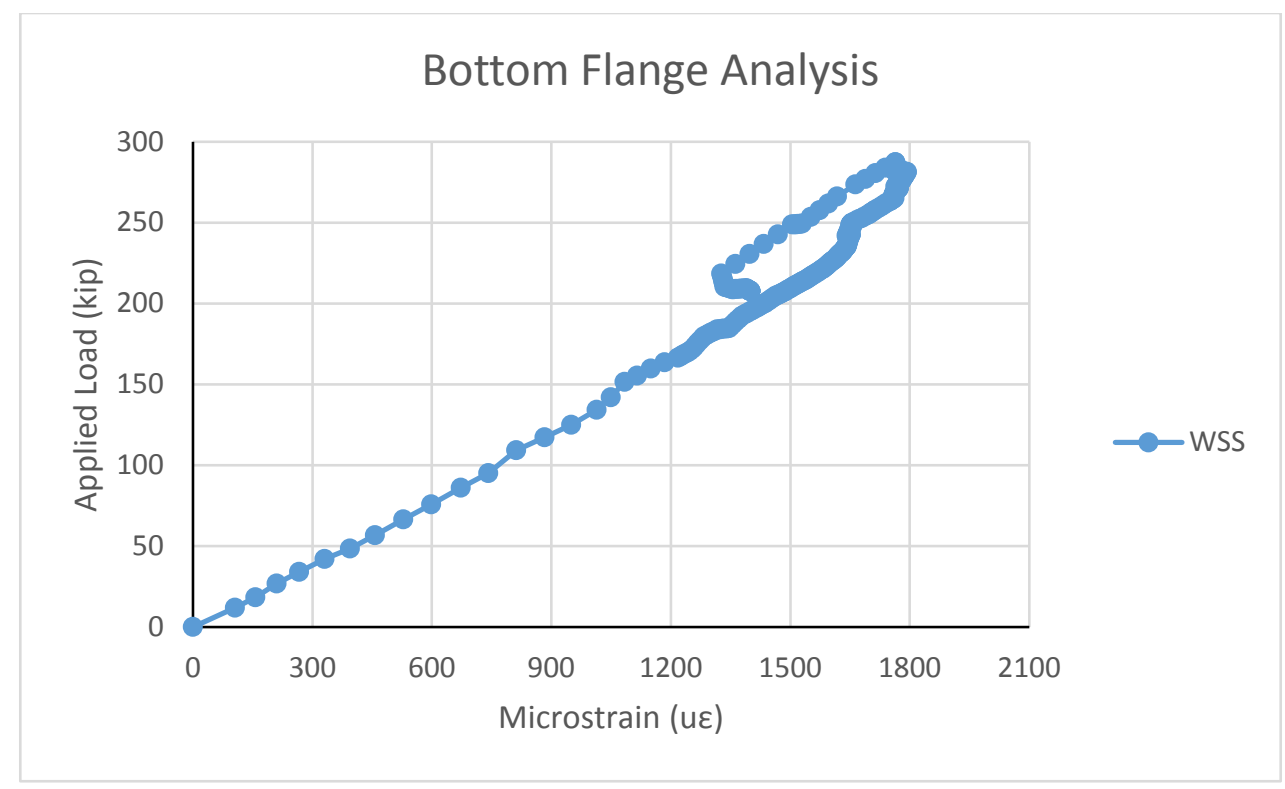

Figure 5.36: Bottom Flange Load-Strain Data from Flexural Testing Uncoated Steel Specimen 


\subsection{SUMMARY}

This chapter summarized the results obtained throughout the testing of the different specimens. Hewlig and Fan's method to determine the longitudinal stresses from the strains obtained from the gages, in conjunction with Imhoff's procedure to calculate the induced moment from the stresses found, proved to be effective tools in the analysis of the obtained data. After some of the gages were removed for behaving inconsistently, a linear regression algorithm was also used to further reduce the error. Each girder behaved consistently for the entirety of the testing on each specimen, not varying significantly within its loading cycle. A difference in the magnitude of deflections and stresses is present between the two specimens, but the difference is constant through the test, so neither specimen behaved worse than the other through the testing. Overall, both steel specimens exhibited satisfactory performance through the fatigue analysis. 


\section{CHAPTER 6: PROJECT SUMMARY AND RECOMMENDATIONS FOR FUTURE WORK}

\subsection{Project Summary}

The scope of this project was to evaluate the fatigue performance of modular press-brakeformed tub girders with differing steel types. This was accomplished by testing full-scale 38 foot composite girders inside a laboratory. The composite units consisted of a press-brake-formed tub girder with a six inch concrete deck cast on top of the upper flanges of the girder. The first girder consisted of ASTM A709 Grade 50 uncoated steel and the other consisted of ASTM A709 Grade 50 steel hot-dipped galvanized prior to arrival at the laboratory. Each specimen was fatigue tested to simulate a 75 year period in a non-interstate rural environment with an ADT of 800 vehicles, $15 \%$ of which were assumed to be truck traffic. A Service II moment was induced into each specimen at a predetermined number of cycles to evaluate the performance of each specimen. Based on the collected and analyzed strain gage and LVDT data, performance of each specimen behaved consistently throughout the entirety of the test. While the low strength of the concrete used in the galvanized steel specimen lead to overall higher strains and deflections, the specimens behaved similarly at every stage of testing, with the stresses increasing at approximately the same rate for each specimen. The data collected show the heat of the galvanization process does not have an adverse effect on the fatigue performance of cold bent press-brake-formed steel tub girders.

\subsection{RECOMMENDATIONS FOR CONTINUED RESEARCH}

Based on this study, the following recommendations for future work are given:

- Research could be conducted into the viability of longer span bridges using spliced tub girders. Performance of the composite system in negative flexure could lead to feasibility of press-brake-formed tub girders over longer spans and continuous span applications. 
- The casting of the concrete deck in controlled conditions could benefit from improved detailing of the SIP metal formwork in the interior of the tub girder. Research into the effectiveness of crimping versus pour stop angles could improve the cost-effectiveness of the system.

- Once the press-brake-formed steel tub girder has been implemented for mainstream use, long-term monitoring may provide valuable information regarding fatigue performance.

- Research on improved live load distribution factors for steel box girders with a concrete deck could be conducted. For other types of superstructures, there are different distribution factors for whether shear or moment are being distributed to either interior or exterior beams and there is only one distribution factor for all beams in all cases for steel box girders with concrete decks. 


\section{REFERENCES}

(2014). AASHTO LRFD bridge design specifications. Washington, DC: American Association of State Highway and Transportation Officials.

(4 Jul 2016). Weathering steel: A guide to Corten and the A/B equivalents, origins \& standards. Retrieved from www.azom.com/article.aspx?ArticleID=12974.

Adams, M., Nicks, J., Stabile, T., Wu, J., Schlatter, W., \& Hartmann, J. (2011). Geosynthetic reinforced soil integrated bridge system, synthesis report (Report No. FHWA-HRT-11027). U. S. Department of Transportation, Federal Highway Administration.

Barth, K. E., Barth, A. S., Michaelson, G. K., Gibbs, C. L., \& Tennant, R. M. (2017). Evaluation of SMDI short span steel bridge design standards.

Barth, K., Albrecht, P., \& Righman, J. (2005). Performance of weathering steel bridges in West Virginia.

Bentley Systems, Inc. (2008). LEAP CONSYS ${ }^{\mathrm{TM}}$ AASHTO standard and LRFD live and static load analysis user manual (Version 01.03.02.00) [Computer Software].

Bertoldi, A. G. (2009). A strength and serviceability assessement of high performance steel bridge 10462 (Master’s thesis). Available from ProQuest.

Burgueño, R., \& Pavlich, B. S. (2008). Evaluation of prefabricated composite steel box girder systems for rapid bridge construction. (Report No. RC-1507).

Burner, K. A. (2010). Experimental investigation of folded plate girders and slap joints used in modular construction (Master's Thesis). Available from University of Nebraska-Lincoln Database.

Chandar, G., Hyzak, M. D., \& Wolf, L. M. (2010). Rapid, economical bridge replacement. Available from Modern Steel Construction.

Chen, B. S., Yura, J. A., Williamson, E. B., \& Frank, K. H. (2005). Top-lateral bracing systems for trapezoidal steel box-girder bridges. (Report No. FHWA/TX-07/0-1898-4). 
Corus Construction \& Industrial. (2004). The prevention of corrosion on structural steelwork. Scunthorpe, Lincolnshire: Corus Construction \& Industrial.

Culmo, M. P. (2011). Accelerated bridge construction: Experience in design, fabrication and erection of prefabricated bridge elements and systems (Report No. FHWA-HIF-12-013). U. S. Department of Transportation, Federal Highway Administration.

Ghavamian, A., Maghami, M. R., \& Gomes, C. (2015). Concerns of corrosive effects with respect to lightning protection systems. Engineering Failure Analysis, November 2015. doi:101016/j.engfailanal.2015008.019

Gibbs, C. L. (2017). Field performance assessment of press-brake-formed steel tub girder superstructures (Master’s thesis). Available from ProQuest.

Gilchrist, C. L., Yura, J. A., \& Frank, K. H. (1997). Buckling behavior of U-shaped girders. (Report No. FHWA/TX-97/0-1395-1).

Glaser, L. A. (2010). Constructability testing of folded plate girders (Master's Thesis). Available from University of Nebraska-Lincoln Database.

Helwig, T. A., \& Fan, Z. (2000). Field and computational studies of steel trapezoidal box girder bridges (Report No. 1395-3). Austin, Texas: Texas Department of Transportation.

Hudson, R. (2004). The prevention of corrosion on structural steelwork. Corus Construction and Industrial. Corus: North Lincolnshire.

Imhoff, C. M. (1998). Testing and modeling of Bridge R-289. (Master's Thesis). Available from University of Missouri.

Kassimali, A. (2015). Structural analysis (5th ed.). Stamford, CT: Cengage Learning.

Kelly, L. T. (2014). Experimental evaluation of non-composite shallow press-brake-formed steel tub girders (Master’s thesis). Available from ProQuest.

Kline, E. (2009). Durable bridge coatings. Modern Steel Construction, 46-50.

Kozhokin, P. (2016). Evaluation of modular press-brake-formed tub girders with UHPC joints (Master’s thesis). Available from ProQuest. 
Masteel UK, Ltd. (2016). Weathering steel: A guide to Corten and the A/B equivalents, origins and standards. Retrieved from https://www.azom.com/.

Michaelson, G. K. (2014). Development and feasibility assessment of shallow press-brake-formed steel tub girders for short-span bridge applications (Doctoral dissertation). Available from ProQuest.

Micro-Measurements, Inc. (2010). StrainSmart [Data Collection]. Raleigh, North Carolina: MicroMeasurements, Inc.

Nakamura, S. (2002). Bending behavior of composite girders with cold formed steel U section. ASCE Journal of Structural Engineering, 128(9), 1169-1176. Doi: 10.1061-(ASCE)07339455(2002)128:9(1169).

National Physical Laboratory. (2000). Coating for the protection of structural steelwork. Teddington, Middlesex: Crown.

Olson, A., Williams, T., Hudson, M., \& Fleming, D. W. (3 Mar 2017). Steel bridges protected with two-coat polyaspartic urethane coatings. Retrieved from www.materialsperformance.com/articles/cathodic-protection/2017/01/steel-bridgesprotected-with-two-coat-polyaspartic-urethane-coatings.

Phares, B., Deng, Y., \& Steffens, O. (2017). Evaluation of a folded plate girder bridge system. (Report No. InTrans Project 13-458).

Taly, N. B., \& GangaRao, H. V. S. (1976). Development and design of standardized short span bridge superstructural. (Report No. FHWA-WV-76-5).

Tricon Engineering Group, Ltd. (2008). Standard design and details of press-brake-formed steel tub girder. Tricon Engineering Group: Michigan.

U. S. Department of Transportation, Federal Highway Administration. (2013). Slide-in bridge construction implementation guide: Planning and executing projects with the lateral slide method (Project No. F-ST99(232)).

U. S. Department of Transportation, Federal Highway Administration. (2014). Every day counts: Accelerated bridge construction. 


\section{APPENDiX A: LoAding CALCUlations}

Influence Line analysis was used to determine the moments at the midspan of a simply supported beam. Equation A1.1 displays the set of functions for the moment at midspan:

$$
f(x)=\left\{\begin{array}{cc}
x / 2 & {[0, L / 2]} \\
(L-x) / 2 & {[L / 2, L]}
\end{array}\right.
$$

The AASHTO fatigue load model consists of a single HL-93 truck with a rear axle spacing fixed at 30 feet. Using a load factor of 1.75 for an infinite life fatigue, an impact factor of 1.15 and a live load distribution factor of 1.00, the Fatigue I moment was determined according to Equation A1.2:

$$
M_{\text {Fatigue I }}=(1.75)(1.15)(1.00) M_{\text {Fatigue Truck }}
$$

Since the fatigue truck is longer than the bridge span, only the front and middle axles were used to determine the highest moment induced at midspan. Figure A1.1 shows the AASHTO fatigue truck placement.

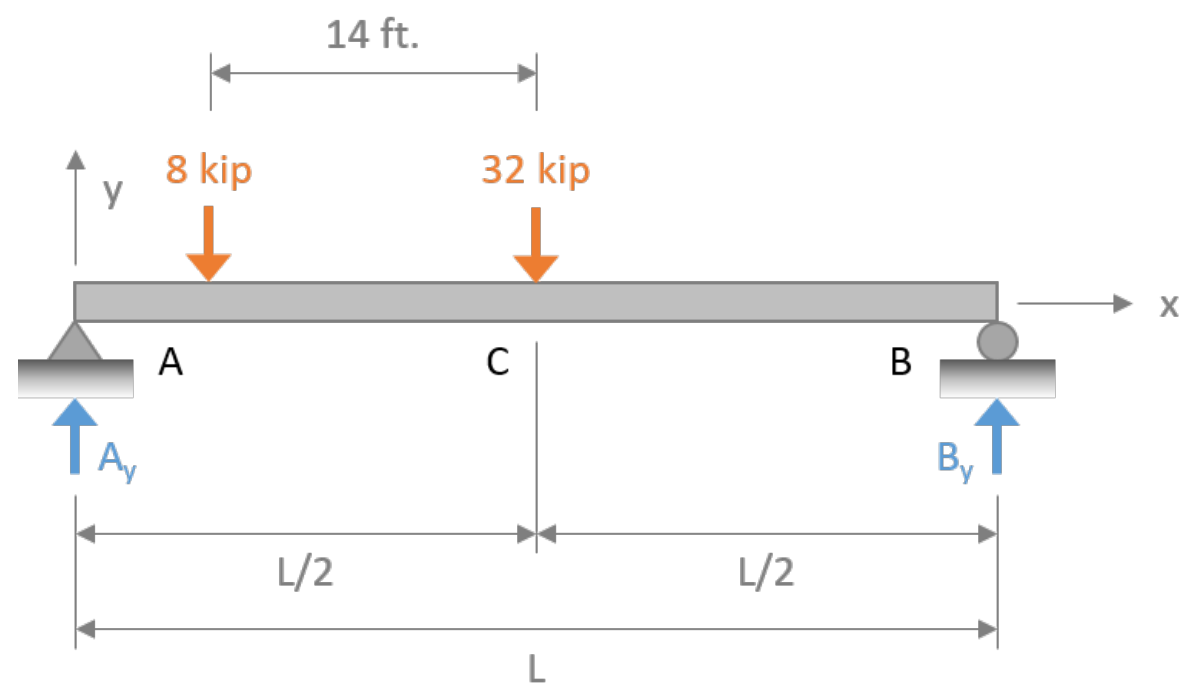

Figure A.1: HL-93 Fatigue Truck Placement 
Using the influence line method, the fatigue-induced moment was determined as follows:

$$
\begin{aligned}
M_{\text {Fatigue Truck }} & =\sum_{i=1}^{n} P_{i} \times f\left(x_{i}\right) \\
& =8 \times f(L / 2-14)+32 \times f(L / 2) \\
& =8 \times(L / 4-7)+32 \times f(L / 4) \\
& =2 L-56+8 L \\
& M_{\text {Fatigue Truck }}=10 L-56
\end{aligned}
$$

Therefore, the moment at midspan due to design fatigue loading for infinite life is as follows:

$$
\begin{aligned}
\qquad M_{\text {Fatigue I }} & =(1.75)(1.15)(1.00)(10 \mathrm{~L}-56) \\
{ }^{*} \text { For L=37.00ft (Uncoated Steel) } & =(1.75)(1.15)(1.00)(314) \\
& =631.93 \mathrm{kip}-\mathrm{ft} \\
{ }^{*} \text { For L=37.50 ft (Galvanized Steel) } & =(1.75)(1.15)(1.00)(319) \\
& =641.99 \mathrm{kip}-\mathrm{ft}
\end{aligned}
$$

To determine a point load to induce this moment, the equation for moment in a simply supported beam was rearranged:

$$
\begin{aligned}
& P_{\text {Fatigue I }}=\frac{4 M_{\text {Fatigue I }}}{L} \\
& { }^{*} \text { For } L=37.00 \mathrm{ft} \text { (Uncoated Steel) } \quad=\frac{4 \times 631.93}{37.00} \\
& =68.32 \mathrm{kip} \\
& { }^{*} \text { For } L=37.50 \mathrm{ft} \text { (Galvanized Steel) } \quad=\frac{4 \times 641.99}{37.50} \\
& =68.48 \text { kip }
\end{aligned}
$$


A similar procedure was used to determine the Service II moment. The AASHTO HL-93 load model consists of either the truck and the lane or the tandem and the lane. Using a load factor of 1.30 for Service II, an impact factor of 1.33 and a live load distribution factor of 1.00 , the Service II moment was determined using Equation A1.3:

$$
M_{\text {Service II }}=(1.30)(1.00)\left(1.33 M_{\text {Vehicle }}+M_{\text {Lane }}\right)
$$

Figure A1.2 shows the HL-93 Truck placement on the simple span bridge.

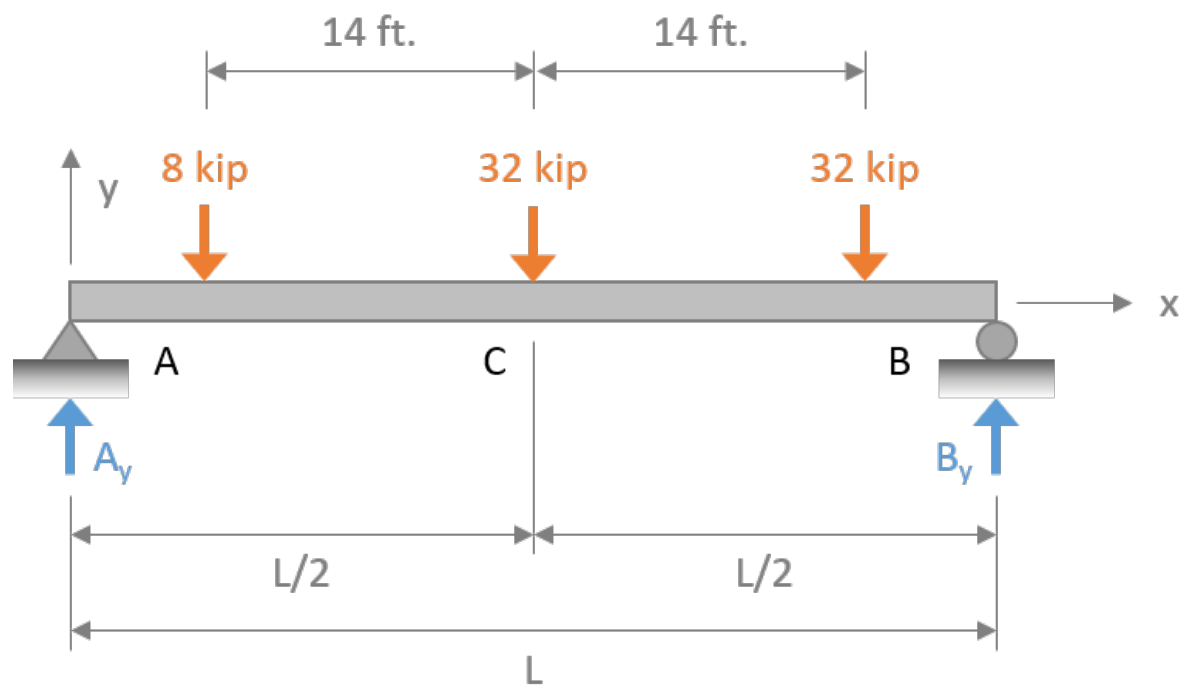

Figure A.2: HL-93 Truck Placement

Using the influence line method, the moment induced by the HL-93 Truck was determined as follows:

$$
\begin{aligned}
M_{\text {Truck }} & =\sum_{i=1}^{n} P_{i} \times f\left(x_{i}\right) \\
& =8 \times f(L / 2-14)+32 \times f(L / 2)+32 \times f(L / 2+14) \\
& =8 \times(L / 4-7)+32 \times f(L / 4)+32 \times(L / 4-7) \\
& =2 L-56+8 L+8 L-224 \\
& M_{\text {Truck }}=18 L-280
\end{aligned}
$$


Figure A1.3 shows the HL-93 Tandem placement on the simple span bridge.

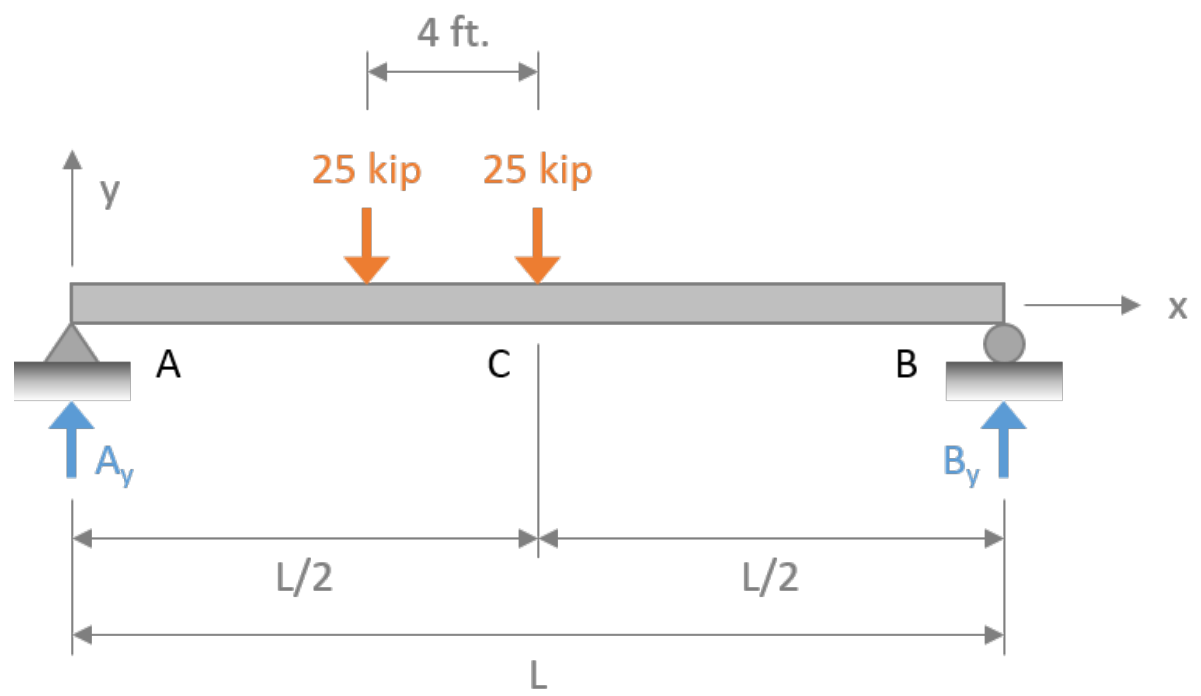

Figure A.3: HL-93 Tandem Placement

Using the influence line method, the moment induced by the HL-93 Tandem was determined as follows:

$$
\begin{aligned}
M_{\text {Tandem }} & =\sum_{i=1}^{n} P_{i} \times f\left(x_{i}\right) \\
& =25 \times f(L / 2-4)+25 \times f(L / 2) \\
& =25 \times(L / 4-2)+25 \times f(L / 4) \\
& =6.25 L-50+6.25 L \\
& M_{\text {Tandem }}=12.5 L-50
\end{aligned}
$$

Figure A1.4 shows the HL-93 Lane model. 


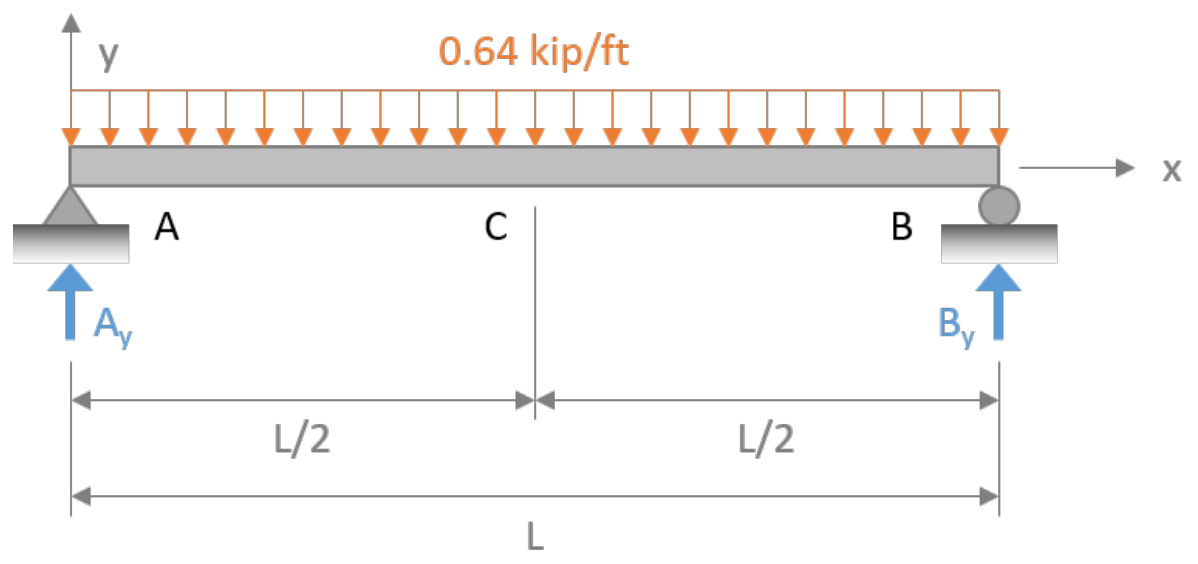

Figure A.4: HL-93 Lane Model

The moment at midspan is determined as follows:

$$
\begin{aligned}
M_{\text {Lane }} & =\sum_{i=1}^{n} w_{i} \times A_{i} \\
& =0.64 \times\left(L^{2} / 8\right) \\
& M_{\text {Lane }}=0.08 L^{2}
\end{aligned}
$$

Using a 37 foot clear span, for the uncoated steel specimen, moments due to the individual HL-93 Truck, Tandem, and Lane components were determined and are summarized in Table A1.1.

Table A.1: Summary of Moments for Uncoated Steel Specimen by Individual Components

\begin{tabular}{|c|c|}
\hline Component & Moment (kip-ft) \\
\hline HL-93 Truck & 386 \\
\hline HL-93 Tandem & 412.5 \\
\hline HL-93 Lane & 109.52 \\
\hline
\end{tabular}

The greater of the moments induced by either the truck or the tandem is used in Equation A1.3 as a vehicular load. Therefore, using the moments induced by the tandem and the lane components, the Service II moment was determined:

$$
M_{\text {Service II }}=(1.30)(1.00)(1.33 \times 412.5+109.52)=855.59 \mathrm{kip}-f t
$$


To determine a point load to induce this moment, the equation for moment in a simply supported beam was rearranged:

$$
\begin{aligned}
& P_{\text {Service II }}=\frac{4 M_{\text {Serivce II }}}{L} \\
& { }^{*} \text { For } L=37.00 \mathrm{ft} \text { (Uncoated Steel) } \quad=\frac{4 \times 855.59}{37.00} \\
& =92.50 \mathrm{kip}
\end{aligned}
$$

Using a 37.5 foot clear span, for the galvanized steel specimen, moments due to the individual HL-93 Truck, Tandem, and Lane components were determined and are summarized in Table A1.2.

Table A.2: Summary of Moments for Galvanized Steel Specimen by Individual Components

\begin{tabular}{|c|c|}
\hline Component & Moment (kip-ft) \\
\hline HL-93 Truck & 395 \\
\hline HL-93 Tandem & 418.75 \\
\hline HL-93 Lane & 112.5 \\
\hline
\end{tabular}

The greater of the moments induced by either the truck or the tandem is used in Equation A1.3 as a vehicular load. Therefore, using the moments induced by the tandem and the lane components, the Service II moment was determined:

$$
M_{\text {Service II }}=(1.30)(1.00)(1.33 \times 418.75+112.5)=870.27 \mathrm{kip}-f t
$$

To determine a point load to induce this moment, the equation for moment in a simply supported beam was rearranged:

$$
\begin{aligned}
& P_{\text {Service II }}=\frac{4 M_{\text {Serivce II }}}{L} \\
& { }^{*} \text { For } L=37.00 \mathrm{ft} \text { (Uncoated Steel) } \quad=\frac{4 \times 870.27}{37.50} \\
& =92.83 \mathrm{kip}
\end{aligned}
$$




\section{APPENDIX B: GAGE DATA}

\section{Original RaW Data From Uncoated SteEl SPECIMEN}

\begin{tabular}{|c|c|c|c|c|c|c|c|c|c|c|c|}
\hline \multirow{2}{*}{ Gage } & \multicolumn{10}{|c|}{ Original Raw Data $(\mathrm{N}=0)$} \\
\cline { 2 - 13 } & $\mathrm{P}=0.00 \mathrm{k}$ & $\mathrm{P}=9.25 \mathrm{k}$ & $\mathrm{P}=18.50 \mathrm{k}$ & $\mathrm{P}=27.75 \mathrm{k}$ & $\mathrm{P}=37.00 \mathrm{k}$ & $\mathrm{P}=46.25 \mathrm{k}$ & $\mathrm{P}=55.50 \mathrm{k}$ & $\mathrm{P}=64.75 \mathrm{k}$ & $\mathrm{P}=74.00 \mathrm{k}$ & $\mathrm{P}=83.25 \mathrm{k}$ & $\mathrm{P}=92.50 \mathrm{k}$ \\
\hline G01 & 0 & -15.224 & -0.1663 & 55.814 & 39.2439 & 44.2175 & 52.0127 & 74.2791 & 73.9819 & 84.55 & 116.7128 \\
\hline G02 & 0 & 27.8766 & 49.7993 & 72.5814 & 96.351 & 119.5538 & 143.0262 & 167.0097 & 191.8139 & 216.0558 & 240.7927 \\
\hline G03 & 0 & 51.7089 & 90.2524 & 128.7178 & 166.8543 & 205.0399 & 243.5516 & 281.7342 & 320.2515 & 358.4259 & 397.3667 \\
\hline G04 & 0 & 85.4519 & 148.7265 & 209.5947 & 269.3096 & 328.8922 & 387.7847 & 446.3128 & 504.9409 & 563.808 & 621.1482 \\
\hline G05 & 0 & 87.9375 & 151.3364 & 214.5117 & 276.6729 & 339.0276 & 400.4615 & 462.4605 & 524.1416 & 585.2728 & 646.5511 \\
\hline G06 & 0 & 83.6526 & 143.4869 & 202.9065 & 262.0993 & 321.0648 & 379.3814 & 437.7046 & 496.1286 & 554.372 & 612.6219 \\
\hline G07 & 0 & 22.9263 & 35.0565 & 44.49 & 55.2284 & 65.7335 & 74.7015 & 84.9734 & 94.3118 & 105.703 & 113.5117 \\
\hline G08 & 0 & 14.2775 & 13.1899 & 28.6214 & 57.7037 & 83.4308 & 106.7507 & 144.3436 & 180.6332 & 211.7429 & 246.6887 \\
\hline G09 & 0 & 5.7433 & 9.9543 & 14.9137 & 20.5661 & 27.3762 & 34.5608 & 42.302 & 49.8108 & 58.2897 & 65.7988 \\
\hline G10 & 0 & 5.1218 & 8.8543 & 14.2082 & 19.5617 & 25.4679 & 31.8814 & 39.0325 & 46.4136 & 55.2727 & 65.6124 \\
\hline G11 & 0 & 29.9822 & 51.8642 & 73.4701 & 95.4042 & 116.9191 & 138.2947 & 159.5747 & 182.0612 & 204.5024 & 226.7617 \\
\hline G12 & 0 & 62.4231 & 108.1183 & 153.7263 & 199.1969 & 245.0884 & 290.4742 & 335.8124 & 381.1637 & 426.5641 & 472.0167 \\
\hline G13 & 0 & 53.7736 & 92.9952 & 131.9417 & 170.0101 & 208.6376 & 245.9699 & 284.4642 & 323.982 & 364.6165 & 402.0064 \\
\hline G14 & 0 & 88.1166 & 151.9623 & 215.2586 & 278.2842 & 341.3642 & 404.5456 & 467.0839 & 529.8623 & 592.4629 & 654.9785 \\
\hline G15 & 0 & 77.5802 & 143.8021 & 203.1633 & 264.7594 & 327.1993 & 389.4609 & 452.0091 & 514.5183 & 573.2268 & 651.5001 \\
\hline G16 & 0 & 57.7601 & 99.4894 & 140.894 & 182.7224 & 225.201 & 267.7752 & 310.2594 & 353.2595 & 396.8176 & 439.4068 \\
\hline G17 & 0 & 31.5189 & 55.1825 & 79.2186 & 103.6686 & 128.8622 & 154.009 & 179.4338 & 205.0908 & 231.2133 & 257.3377 \\
\hline G18 & 0 & 12.3004 & 22.75 & 33.0099 & 43.9709 & 54.7888 & 66.1231 & 77.2221 & 88.7421 & 100.2647 & 111.5069 \\
\hline
\end{tabular}

\begin{tabular}{|c|c|c|c|c|c|c|c|c|c|c|c|c|}
\hline \multirow{2}{*}{ Gage } & \multicolumn{10}{|c|}{ Original Raw Data $(\mathrm{N}=100,000)$} \\
\cline { 2 - 12 } & $\mathrm{P}=0.00 \mathrm{k}$ & $\mathrm{P}=9.25 \mathrm{k}$ & $\mathrm{P}=18.50 \mathrm{k}$ & $\mathrm{P}=27.75 \mathrm{k}$ & $\mathrm{P}=37.00 \mathrm{k}=46.25 \mathrm{k}$ & $\mathrm{P}=55.50 \mathrm{k}$ & $\mathrm{P}=64.75 \mathrm{k}$ & $\mathrm{P}=74.00 \mathrm{k}$ & $\mathrm{P}=83.25 \mathrm{k}$ & $\mathrm{P}=92.50 \mathrm{k}$ \\
\hline G01 & 0 & -1.3916 & 0.2603 & 3.2465 & 6.7378 & 10.9665 & 15.425 & 20.9883 & 26.5528 & 32.7688 & 38.8385 \\
\hline G02 & 0 & 26.1061 & 47.1532 & 69.1598 & 91.8728 & 114.5978 & 137.7329 & 161.7933 & 185.836 & 209.7515 & 234.1213 \\
\hline G03 & 0 & 50.3726 & 88.3118 & 126.3485 & 164.5726 & 202.5639 & 240.6064 & 279.2057 & 317.2519 & 355.5355 & 393.9561 \\
\hline G04 & 0 & 85.4492 & 149.3835 & 212.026 & 273.1917 & 333.5755 & 393.4096 & 452.6936 & 510.9166 & 566.4068 & 626.9654 \\
\hline G05 & 0 & 87.4591 & 151.485 & 214.9147 & 277.1459 & 339.198 & 400.7937 & 462.5368 & 523.7757 & 584.6973 & 645.812 \\
\hline G06 & 0 & 83.3322 & 144.3883 & 203.9538 & 262.9174 & 321.7003 & 380.0685 & 438.4908 & 496.5446 & 554.746 & 613.0009 \\
\hline G07 & 0 & 27.6365 & 42.8402 & 56.5075 & 70.2712 & 84.1276 & 97.3321 & 111.8376 & 127.5107 & 144.0669 & 217.9184 \\
\hline G08 & 0 & 80.7727 & 116.5919 & 169.9238 & 194.2392 & 237.3874 & 257.0743 & 283.0763 & 296.9662 & 329.2492 & 350.4917 \\
\hline G09 & 0 & 2.0285 & 4.572 & 9.9874 & 15.8672 & 22.1164 & 28.9197 & 36.8337 & 44.7491 & 52.7121 & 61.829 \\
\hline G10 & 0 & 3.964 & 8.013 & 16.5956 & 24.2988 & 30.802 & 37.7629 & 44.7238 & 51.5924 & 55.6865 & 62.7376 \\
\hline G11 & 0 & 27.0394 & 49.1794 & 70.9476 & 93.5072 & 115.6023 & 137.9755 & 160.4887 & 182.4033 & 206.4926 & 229.7024 \\
\hline G12 & 0 & 60.193 & 106.0897 & 151.4391 & 196.8394 & 242.6583 & 288.2037 & 333.9368 & 378.5232 & 424.3073 & 469.4551 \\
\hline G13 & 0 & 53.3929 & 93.7658 & 133.1221 & 172.9914 & 211.9831 & 251.6733 & 291.5987 & 331.6196 & 371.5979 & 412.9706 \\
\hline G14 & 0 & 87.7729 & 152.7192 & 216.7455 & 280.3615 & 343.3821 & 405.9464 & 469.4934 & 531.5158 & 593.964 & 656.6522 \\
\hline G15 & 0 & 83.3683 & 144.4089 & 204.9468 & 264.7967 & 324.4221 & 383.9616 & 443.508 & 503.0157 & 564.8033 & 624.5108 \\
\hline G16 & 0 & 57.2911 & 99.6231 & 142.2389 & 184.8101 & 227.3897 & 270.3393 & 313.4294 & 355.7372 & 399.1156 & 442.5401 \\
\hline G17 & 0 & 30.5083 & 53.2492 & 77.1001 & 101.7392 & 126.4704 & 151.4371 & 177.3738 & 202.4795 & 228.0949 & 254.3125 \\
\hline G18 & 0 & 11.8351 & 21.7243 & 32.0303 & 42.3322 & 52.6836 & 63.5479 & 74.5522 & 85.6558 & 97.0841 & 108.6073 \\
\hline
\end{tabular}




\begin{tabular}{|c|c|c|c|c|c|c|c|c|c|c|c|c|}
\hline \multirow{2}{*}{ Gage } & \multicolumn{9}{|c|}{ Original Raw Data $(\mathrm{N}=200,000)$} \\
\cline { 2 - 14 } & $\mathrm{P}=0.00 \mathrm{k}$ & $\mathrm{P}=9.25 \mathrm{k}$ & $\mathrm{P}=18.50 \mathrm{k}$ & $\mathrm{P}=27.75 \mathrm{k}=37.00 \mathrm{k}$ & $\mathrm{P}=46.25 \mathrm{k}$ & $\mathrm{P}=55.50 \mathrm{k}$ & $\mathrm{P}=64.75 \mathrm{k}$ & $\mathrm{P}=74.00 \mathrm{k}$ & $\mathrm{P}=83.25 \mathrm{k}$ & $\mathrm{P}=92.50 \mathrm{k}$ \\
\hline G01 & 0 & -0.2342 & 0.8145 & 3.9805 & 8.1141 & 13.1216 & 18.5891 & 24.38 & 31.1869 & 38.0826 & 44.746 \\
\hline G02 & 0 & 26.1383 & 45.8308 & 67.6393 & 90.0788 & 113.4274 & 136.6076 & 160.4773 & 184.5262 & 208.6743 & 233.0499 \\
\hline G03 & 0 & 51.5174 & 89.5026 & 127.7195 & 166.2643 & 204.6283 & 243.4107 & 282.0107 & 320.519 & 359.0312 & 397.5 \\
\hline G04 & 0 & 89.7971 & 155.4267 & 218.1868 & 283.0902 & 362.3036 & 424.1605 & 486.5361 & 547.9903 & 608.8943 & 669.4344 \\
\hline G05 & 0 & 89.4933 & 153.8385 & 217.1238 & 280.0921 & 342.3249 & 404.5655 & 465.8382 & 527.3044 & 588.6854 & 649.7019 \\
\hline G06 & 0 & 85.9915 & 147.6975 & 207.4908 & 267.3849 & 326.5369 & 385.6961 & 444.2999 & 502.8168 & 561.247 & 619.9183 \\
\hline G07 & 0 & 37.4341 & 73.4075 & 86.1268 & 97.6356 & 153.3023 & 161.4089 & 174.8818 & 190.5905 & 205.9299 & 214.5966 \\
\hline G08 & 0 & 26.2052 & 41.9803 & 54.9665 & 70.6722 & 86.2798 & 106.1815 & 124.1632 & 146.5473 & 166.7346 & 192.0807 \\
\hline G09 & 0 & 2.9519 & 4.7997 & 9.8445 & 16.0908 & 22.5706 & 30.6691 & 38.4914 & 46.9598 & 55.3848 & 64.5023 \\
\hline G10 & 0 & 3.7198 & 8.6894 & 15.3214 & 23.8905 & 31.0747 & 39.6901 & 48.6789 & 56.7889 & 65.6848 & 74.5805 \\
\hline G11 & 0 & 30.0773 & 52.5298 & 75.5873 & 98.8767 & 121.7947 & 145.3624 & 168.6567 & 192.0887 & 215.2007 & 238.775 \\
\hline G12 & 0 & 61.4769 & 106.7775 & 152.0787 & 198.027 & 243.4296 & 288.7882 & 334.3364 & 379.4285 & 424.2478 & 469.1628 \\
\hline G13 & 0 & 58.9763 & 101.5569 & 143.5385 & 185.5235 & 227.3271 & 269.4583 & 311.6859 & 354.0561 & 396.476 & 439.4099 \\
\hline G14 & 0 & 90.1455 & 155.3274 & 219.1714 & 283.2556 & 346.7907 & 410.0553 & 472.4449 & 534.8888 & 597.2012 & 659.986 \\
\hline G15 & 0 & 87.5103 & 150.5105 & 211.4784 & 273.2888 & 334.3643 & 395.1231 & 455.425 & 516.291 & 576.4683 & 637.0707 \\
\hline G16 & 0 & 58.9533 & 101.1476 & 143.2981 & 186.2862 & 228.5824 & 271.9944 & 314.6699 & 357.9005 & 400.6279 & 444.2823 \\
\hline G17 & 0 & 31.2565 & 52.9857 & 76.6149 & 101.0743 & 125.9985 & 151.3389 & 176.4978 & 202.302 & 228.4363 & 254.3371 \\
\hline G18 & 0 & 12.729 & 22.1531 & 31.9457 & 42.7669 & 53.4457 & 64.1222 & 74.7539 & 86.3239 & 97.3332 & 108.9028 \\
\hline
\end{tabular}

\begin{tabular}{|c|c|c|c|c|c|c|c|c|c|c|c|c|}
\hline \multirow{2}{*}{ Gage } & \multicolumn{9}{|c|}{ Original Raw Data $(\mathrm{N}=300,000)$} \\
\cline { 2 - 14 } & $\mathrm{P}=0.00 \mathrm{k}$ & $\mathrm{P}=9.25 \mathrm{k}$ & $\mathrm{P}=18.50 \mathrm{k}$ & $\mathrm{P}=27.75 \mathrm{k}$ & $\mathrm{P}=37.00 \mathrm{k}$ & $\mathrm{P}=46.25 \mathrm{k}$ & $\mathrm{P}=55.50 \mathrm{k}$ & $\mathrm{P}=64.75 \mathrm{k}$ & $\mathrm{P}=74.00 \mathrm{k}$ & $\mathrm{P}=83.25 \mathrm{k}$ & $\mathrm{P}=92.50 \mathrm{k}$ \\
\hline G01 & 0 & -2.4549 & -1.8629 & 0.9397 & 5.4364 & 9.614 & 14.8481 & 20.4679 & 26.807 & 33.2782 & 40.1194 \\
\hline G02 & 0 & 26.5349 & 46.5598 & 68.648 & 91.0131 & 113.5851 & 137.2154 & 161.0398 & 184.0047 & 208.2103 & 232.772 \\
\hline G03 & 0 & 51.6012 & 89.4413 & 128.2115 & 166.7044 & 204.973 & 243.7511 & 281.8395 & 320.3409 & 359.125 & 397.4499 \\
\hline G04 & 0 & 89.552 & 153.7322 & 217.0397 & 279.3799 & 339.6852 & 400.1369 & 459.9458 & 519.0652 & 578.1453 & 636.8602 \\
\hline G05 & 0 & 89.2353 & 153.9195 & 217.4047 & 280.4336 & 342.2622 & 404.1453 & 465.5711 & 526.5862 & 587.6552 & 648.546 \\
\hline G06 & 0 & 85.9068 & 147.3385 & 207.3256 & 266.9454 & 324.8857 & 383.9104 & 441.6769 & 499.6373 & 557.7922 & 616.1412 \\
\hline G07 & 0 & 20.5825 & 34.2895 & 48.0455 & 61.2865 & 74.3485 & 87.5921 & 101.0808 & 114.6295 & 127.7768 & 141.2546 \\
\hline G08 & 0 & 21.3509 & 37.8991 & 56.6386 & 76.139 & 95.2825 & 116.9278 & 135.8675 & 156.7584 & 177.7937 & 200.0107 \\
\hline G09 & 0 & 2.4446 & 3.8304 & 8.7355 & 15.7218 & 22.0156 & 30.1144 & 38.2593 & 46.6845 & 55.8003 & 64.1768 \\
\hline G10 & 0 & 4.2002 & 8.8953 & 15.4381 & 22.8984 & 29.9008 & 38.1006 & 46.7145 & 55.0552 & 63.4821 & 72.2774 \\
\hline G11 & 0 & 29.3058 & 51.2115 & 74.0462 & 97.2918 & 119.9417 & 143.1929 & 166.7718 & 189.4701 & 213.2333 & 236.299 \\
\hline G12 & 0 & 61.3276 & 106.6623 & 152.3654 & 198.257 & 243.3269 & 288.6759 & 333.8432 & 378.5113 & 423.5962 & 468.1777 \\
\hline G13 & 0 & 56.2099 & 97.7339 & 138.4736 & 179.0774 & 219.221 & 259.507 & 299.9349 & 339.8564 & 380.4769 & 421.2394 \\
\hline G14 & 0 & 89.3537 & 154.8126 & 219.3047 & 283.3875 & 346.1775 & 408.9295 & 471.503 & 533.5736 & 596.1165 & 658.1091 \\
\hline G15 & 0 & 87.5717 & 150.781 & 212.7005 & 274.3961 & 334.662 & 395.1669 & 456.2356 & 515.8739 & 575.7052 & 635.5898 \\
\hline G16 & 0 & 58.4967 & 100.3207 & 143.0783 & 185.9257 & 228.4607 & 271.2261 & 313.8095 & 356.8137 & 399.6812 & 443.0166 \\
\hline G17 & 0 & 31.2639 & 52.9964 & 76.3488 & 101.5045 & 125.8325 & 150.805 & 176.6142 & 201.9151 & 227.9564 & 253.8139 \\
\hline G18 & 0 & 11.3772 & 20.4266 & 30.1256 & 40.8965 & 50.5441 & 61.4099 & 72.3227 & 83.518 & 94.712 & 105.9556 \\
\hline
\end{tabular}




\begin{tabular}{|c|c|c|c|c|c|c|c|c|c|c|c|c|}
\hline \multirow{2}{*}{ Gage } & \multicolumn{9}{|c|}{ Original Raw Data $(\mathrm{N}=500,000)$} \\
\cline { 2 - 13 } & $\mathrm{P}=0.00 \mathrm{k}$ & $\mathrm{P}=9.25 \mathrm{k}$ & $\mathrm{P}=18.50 \mathrm{k}$ & $\mathrm{P}=27.75 \mathrm{k}=37.00 \mathrm{k}$ & $\mathrm{P}=46.25 \mathrm{k}$ & $\mathrm{P}=55.50 \mathrm{k}$ & $\mathrm{P}=64.75 \mathrm{k}$ & $\mathrm{P}=74.00 \mathrm{k}$ & $\mathrm{P}=83.25 \mathrm{k}$ & $\mathrm{P}=92.50 \mathrm{k}$ \\
\hline G01 & 0 & -2.8609 & -2.6766 & -0.7489 & 2.102 & 6.103 & 10.6576 & 15.808 & 22.5703 & 28.2295 & 34.2106 \\
\hline G02 & 0 & 25.3709 & 45.1768 & 66.5426 & 88.6896 & 111.2588 & 134.4569 & 158.1947 & 182.7483 & 206.8172 & 231.1111 \\
\hline G03 & 0 & 51.565 & 89.9625 & 129.0576 & 167.3725 & 205.5986 & 243.7811 & 282.7072 & 321.3551 & 359.3633 & 397.9242 \\
\hline G04 & 0 & 91.4315 & 157.718 & 222.9916 & 285.9984 & 348.4563 & 410.1323 & 471.3973 & 532.8097 & 593.2538 & 653.5192 \\
\hline G05 & 0 & 90.0336 & 155.6666 & 220.008 & 282.7324 & 345.326 & 406.9517 & 467.6561 & 529.2968 & 590.1089 & 651.1607 \\
\hline G06 & 0 & 87.1382 & 149.5088 & 210.5873 & 270.1409 & 329.3773 & 387.6917 & 446.3381 & 504.9909 & 562.7221 & 620.7853 \\
\hline G07 & 0 & 83.595 & 133.5157 & 169.7949 & 186.9353 & 204.6324 & 220.0087 & 237.4771 & 255.0799 & 271.156 & 288.3936 \\
\hline G08 & 0 & 21.3022 & 37.4133 & 58.2245 & 79.1914 & 101.0613 & 122.3419 & 144.6186 & 167.4049 & 190.2917 & 219.0268 \\
\hline G09 & 0 & -4.1291 & -5.3828 & -1.2659 & 4.6568 & 11.1371 & 19.0501 & 27.195 & 36.357 & 44.5029 & 54.2206 \\
\hline G10 & 0 & 2.0743 & 4.4228 & 9.3097 & 14.7506 & 21.1628 & 27.7106 & 35.7375 & 44.129 & 51.5591 & 59.4437 \\
\hline G11 & 0 & 28.9311 & 50.6528 & 73.0662 & 94.9745 & 117.3016 & 139.6275 & 162.0469 & 185.529 & 207.3967 & 230.4205 \\
\hline G12 & 0 & 62.4621 & 108.1966 & 154.7592 & 200.3615 & 245.9224 & 291.212 & 335.907 & 381.3844 & 425.6755 & 471.0712 \\
\hline G13 & 0 & 58.2241 & 100.5188 & 143.002 & 183.8674 & 225.3849 & 267.4616 & 308.43 & 350.977 & 393.0182 & 435.3873 \\
\hline G14 & 0 & 91.1982 & 157.7035 & 222.7313 & 286.6059 & 350.0238 & 413.0787 & 475.3045 & 537.7702 & 599.5002 & 662.4005 \\
\hline G15 & 0 & 88.3256 & 152.1463 & 214.492 & 276.3354 & 337.6302 & 398.0513 & 458.387 & 519.1011 & 579.0803 & 641.2005 \\
\hline G16 & 0 & 57.344 & 99.5414 & 142.4833 & 185.0158 & 227.6448 & 270.4125 & 313.3247 & 356.8407 & 399.2041 & 442.4934 \\
\hline G17 & 0 & 27.1891 & 47.7127 & 71.2897 & 95.1942 & 119.8393 & 145.412 & 170.7512 & 196.8344 & 222.3193 & 248.5411 \\
\hline G18 & 0 & 10.9158 & 20.3425 & 30.5093 & 40.5768 & 50.8801 & 61.789 & 72.3732 & 83.5657 & 94.3356 & 106.2785 \\
\hline
\end{tabular}

\begin{tabular}{|c|c|c|c|c|c|c|c|c|c|c|c|}
\hline \multirow{2}{*}{ Gage } & \multicolumn{9}{|c|}{ Original Raw Data $(\mathrm{N}=700,000)$} \\
\cline { 2 - 13 } & $\mathrm{P}=0.00 \mathrm{k}$ & $\mathrm{P}=9.25 \mathrm{k}$ & $\mathrm{P}=18.50 \mathrm{k}$ & $\mathrm{P}=27.75 \mathrm{k}$ & $\mathrm{P}=37.00 \mathrm{k}$ & $\mathrm{P}=46.25 \mathrm{k}$ & $\mathrm{P}=55.50 \mathrm{k}$ & $\mathrm{P}=64.75 \mathrm{k}$ & $\mathrm{P}=74.00 \mathrm{k}$ & $\mathrm{P}=83.25 \mathrm{k}$ & $\mathrm{P}=92.50 \mathrm{k}$ \\
\hline G01 & 0 & -8.7076 & -17.6899 & -19.3514 & -16.963 & -12.9651 & -9.0132 & -3.5414 & 2.1591 & 8.3176 & 14.5682 \\
\hline G02 & 0 & 20.1962 & 33.1142 & 51.6221 & 73.2215 & 95.7883 & 118.5416 & 141.586 & 164.2952 & 188.0151 & 212.2587 \\
\hline G03 & 0 & 50.6888 & 86.7345 & 124.8657 & 163.1388 & 201.506 & 239.8781 & 278.5719 & 317.1802 & 356.1115 & 394.5819 \\
\hline G04 & 0 & 94.0825 & 163.2055 & 227.8337 & 289.9165 & 351.4495 & 411.6896 & 472.4941 & 532.2841 & 591.8027 & 651.7925 \\
\hline G05 & 0 & 93.7171 & 162.8906 & 229.1019 & 292.9533 & 355.6519 & 417.3824 & 479.1677 & 539.845 & 601.2271 & 662.0587 \\
\hline G06 & 0 & 89.4401 & 154.6961 & 216.8017 & 276.4526 & 335.2744 & 393.4987 & 450.9864 & 508.6196 & 566.3533 & 624.0926 \\
\hline G07 & 0 & -16.452 & -2.0388 & 11.0255 & 23.8106 & 36.9693 & 49.1045 & 64.3192 & 154.1619 & 163.9197 & 173.6766 \\
\hline G08 & 0 & 17.2275 & 31.586 & 49.7402 & 70.1698 & 91.8599 & 113.7306 & 135.5349 & 158.9243 & 181.803 & 205.4167 \\
\hline G09 & 0 & -11.0271 & -16.9077 & -14.9174 & -9.6871 & -2.6507 & 4.5691 & 12.6223 & 21.2342 & 29.7982 & 38.8713 \\
\hline G10 & 0 & -3.3379 & -8.5689 & -6.7883 & -1.3118 & 5.4585 & 12.6924 & 19.877 & 27.7105 & 35.9141 & 43.703 \\
\hline G11 & 0 & 25.596 & 42.4087 & 62.9189 & 85.1905 & 107.5086 & 129.9225 & 152.4766 & 175.8644 & 198.8368 & 221.9498 \\
\hline G12 & 0 & 61.2985 & 105.8587 & 152.0777 & 197.5658 & 243.4261 & 288.3707 & 333.4565 & 378.4112 & 423.6424 & 468.4644 \\
\hline G13 & 0 & 60.3699 & 105.5944 & 148.4133 & 190.1697 & 232.0222 & 272.9047 & 314.4396 & 355.5147 & 398.3082 & 439.9001 \\
\hline G14 & 0 & 93.9911 & 164.2171 & 231.4799 & 295.8247 & 359.7594 & 422.7268 & 485.7015 & 547.6618 & 610.0479 & 672.3023 \\
\hline G15 & 0 & 91.8151 & 159.4474 & 223.9364 & 285.8365 & 347.1414 & 407.4801 & 468.1972 & 527.9469 & 588.2145 & 648.8604 \\
\hline G16 & 0 & 56.5523 & 99.4463 & 142.5246 & 185.1016 & 227.8217 & 270.315 & 313.5492 & 356.232 & 399.6609 & 442.9059 \\
\hline G17 & 0 & 24.2322 & 42.8182 & 65.4264 & 89.1054 & 113.6643 & 139.1974 & 164.5451 & 189.7542 & 216.0298 & 241.9357 \\
\hline G18 & 0 & 9.142 & 17.6818 & 27.9391 & 37.5403 & 47.7972 & 58.2859 & 68.6363 & 79.8744 & 91.1179 & 102.5919 \\
\hline
\end{tabular}




\begin{tabular}{|c|c|c|c|c|c|c|c|c|c|c|c|c|}
\hline \multirow{2}{*}{ Gage } & \multicolumn{10}{|c|}{ Original Raw Data $(\mathrm{N}=900,000)$} \\
\cline { 2 - 14 } & $\mathrm{P}=0.00 \mathrm{k}$ & $\mathrm{P}=9.25 \mathrm{k}$ & $\mathrm{P}=18.50 \mathrm{k}$ & $\mathrm{P}=27.75 \mathrm{k}$ & $\mathrm{P}=37.00 \mathrm{k}$ & $\mathrm{P}=46.25 \mathrm{k}$ & $\mathrm{P}=55.50 \mathrm{k}$ & $\mathrm{P}=64.75 \mathrm{k}$ & $\mathrm{P}=74.00 \mathrm{k}$ & $\mathrm{P}=83.25 \mathrm{k}$ & $\mathrm{P}=92.50 \mathrm{k}$ \\
\hline G01 & 0 & -8.2002 & -17.9192 & -21.8368 & -19.9545 & -16.5978 & -12.1839 & -7.2155 & -1.5107 & 4.3309 & 10.5033 \\
\hline G02 & 0 & 21.2251 & 34.1022 & 51.3627 & 72.4951 & 94.9675 & 118.0908 & 141.6267 & 165.3948 & 189.765 & 214.0896 \\
\hline G03 & 0 & 51.1867 & 86.9966 & 124.2909 & 162.4165 & 200.9166 & 239.0487 & 277.4168 & 315.509 & 354.2501 & 392.4403 \\
\hline G04 & 0 & 95.4125 & 165.3128 & 231.9268 & 294.6497 & 356.1264 & 417.0998 & 476.9194 & 536.5144 & 595.9301 & 654.8885 \\
\hline G05 & 0 & 94.4265 & 164.399 & 230.9449 & 294.3409 & 356.6766 & 417.9514 & 479.6057 & 540.0125 & 601.4028 & 662.1032 \\
\hline G06 & 0 & 91.3264 & 157.9477 & 220.5043 & 280.8673 & 339.7388 & 398.2892 & 456.3312 & 514.1924 & 572.2949 & 629.982 \\
\hline G07 & 0 & 24.3693 & 38.6441 & 52.5987 & 66.2271 & 79.0633 & 92.7375 & 106.4621 & 119.8651 & 134.0119 & 146.6683 \\
\hline G08 & 0 & 16.8255 & 30.6821 & 47.5584 & 67.738 & 89.0037 & 110.9285 & 133.5533 & 156.4659 & 179.3128 & 202.646 \\
\hline G09 & 0 & -13.0642 & -20.1948 & -20.0991 & -15.4709 & -8.6207 & -0.6622 & 6.7896 & 14.5662 & 23.4508 & 32.2479 \\
\hline G10 & 0 & -8.3236 & -19.2767 & -23.7656 & -20.7256 & -15.5624 & -9.6622 & -3.9455 & 7.4102 & 17.4686 & 22.672 \\
\hline G11 & 0 & 25.517 & 41.5062 & 60.7845 & 82.1436 & 103.9667 & 126.3884 & 148.7698 & 170.7786 & 193.8503 & 216.3684 \\
\hline G12 & 0 & 61.9594 & 106.4186 & 151.7559 & 197.3755 & 242.7473 & 288.141 & 333.4122 & 378.0799 & 423.2275 & 467.6517 \\
\hline G13 & 0 & 59.4364 & 103.0803 & 145.2914 & 185.3281 & 224.8584 & 264.6694 & 304.7622 & 344.4873 & 385.2815 & 425.8012 \\
\hline G14 & 0 & 95.1508 & 165.8527 & 233.0354 & 297.952 & 361.2044 & 424.3261 & 486.3869 & 547.9911 & 610.7179 & 672.8481 \\
\hline G15 & 0 & 92.2061 & 160.7925 & 225.2628 & 286.8212 & 347.6913 & 407.9201 & 468.1562 & 527.3326 & 587.351 & 647.3765 \\
\hline G16 & 0 & 57.1927 & 99.7132 & 141.5427 & 184.0723 & 226.2325 & 269.6447 & 312.3235 & 354.5392 & 398.15 & 440.6981 \\
\hline G17 & 0 & 23.1155 & 41.3277 & 61.8999 & 85.8974 & 110.3136 & 135.8362 & 160.9476 & 185.9678 & 212.1442 & 237.5364 \\
\hline G18 & 0 & 9.4279 & 17.3646 & 26.2702 & 35.9198 & 46.0386 & 56.8098 & 67.0684 & 78.0309 & 89.7903 & 100.5189 \\
\hline
\end{tabular}

\begin{tabular}{|c|c|c|c|c|c|c|c|c|c|c|c|c|c|}
\hline \multirow{2}{*}{ Gage } & \multicolumn{10}{|c|}{ Original Raw Data ( $=1,100,000)$} \\
\cline { 2 - 13 } & $\mathrm{P}=0.00 \mathrm{k}$ & $\mathrm{P}=9.25 \mathrm{k}$ & $\mathrm{P}=18.50 \mathrm{k}$ & $\mathrm{P}=27.75 \mathrm{k}$ & $\mathrm{P}=37.00 \mathrm{k}=46.25 \mathrm{k}$ & $\mathrm{P}=55.50 \mathrm{k}$ & $\mathrm{P}=64.75 \mathrm{k}$ & $\mathrm{P}=74.00 \mathrm{k}=83.25 \mathrm{k}$ & $\mathrm{P}=92.50 \mathrm{k}$ \\
\hline G01 & 0 & -11.2858 & -21.6067 & -25.8501 & -24.802 & -21.6358 & -16.764 & -11.8945 & -5.7826 & 0.1473 & 6.6273 \\
\hline G02 & 0 & 19.3386 & 31.5235 & 47.8618 & 68.7673 & 90.5971 & 113.0715 & 136.4227 & 160.2344 & 184.5621 & 208.9747 \\
\hline G03 & 0 & 50.1257 & 86.1683 & 123.6472 & 161.4537 & 199.6312 & 238.0427 & 276.269 & 314.7767 & 353.4742 & 391.2927 \\
\hline G04 & 0 & 96.2615 & 165.9861 & 233.2129 & 296.2693 & 357.2909 & 417.576 & 477.5435 & 537.2393 & 596.2918 & 655.5837 \\
\hline G05 & 0 & 97.2503 & 167.9137 & 235.7076 & 299.5632 & 361.9869 & 423.7215 & 485.3708 & 546.5169 & 607.4843 & 668.6915 \\
\hline G06 & 0 & 93.724 & 160.9141 & 224.5076 & 285.1584 & 344.4112 & 402.7807 & 461.3915 & 519.6811 & 577.6962 & 635.7648 \\
\hline G07 & 0 & 21.6865 & 34.7653 & 48.231 & 61.4673 & 74.8851 & 88.5038 & 102.2829 & 116.7733 & 130.9508 & 145.9112 \\
\hline G08 & 0 & 15.486 & 28.7573 & 45.7734 & 65.4842 & 86.3887 & 108.7336 & 130.7918 & 153.8676 & 176.4746 & 199.5374 \\
\hline G09 & 0 & -15.2399 & -23.2972 & -24.0371 & -19.78 & -13.4862 & -6.2196 & 1.2304 & 9.7461 & 17.7523 & 26.5461 \\
\hline G10 & 0 & -4.454 & -12.1863 & -12.7064 & -7.2688 & 0.481 & 9.8461 & 19.8606 & 31.7712 & 44.193 & 59.7576 \\
\hline G11 & 0 & 25.3688 & 41.5868 & 60.579 & 82.0248 & 104.0759 & 126.6795 & 149.3325 & 172.7736 & 195.4748 & 218.4556 \\
\hline G12 & 0 & 62.6393 & 106.7 & 152.1843 & 197.4031 & 242.8076 & 287.633 & 332.4994 & 377.3106 & 422.5408 & 467.4061 \\
\hline G13 & 0 & 59.6267 & 102.5791 & 145.1646 & 185.0658 & 224.6919 & 263.8113 & 303.2582 & 343.0328 & 382.8105 & 422.7305 \\
\hline G14 & 0 & 97.4156 & 168.9928 & 237.5158 & 302.38 & 366.4166 & 429.2074 & 491.6806 & 554.3479 & 616.465 & 678.8692 \\
\hline G15 & 0 & 94.0155 & 163.1013 & 228.0691 & 290.1233 & 351.0258 & 411.0536 & 471.414 & 530.9462 & 590.6246 & 650.0787 \\
\hline G16 & 0 & 57.9348 & 100.6865 & 142.8367 & 185.3661 & 227.7586 & 270.2922 & 312.9676 & 355.9682 & 398.373 & 441.7078 \\
\hline G17 & 0 & 22.235 & 39.5694 & 60.0938 & 83.3033 & 107.3926 & 132.3626 & 157.5674 & 183.001 & 208.3904 & 234.4279 \\
\hline G18 & 0 & 10.1483 & 17.251 & 25.8858 & 35.4063 & 45.2537 & 55.5205 & 65.931 & 77.2812 & 87.9276 & 98.9938 \\
\hline
\end{tabular}




\begin{tabular}{|c|c|c|c|c|c|c|c|c|c|c|c|c|}
\hline \multirow{2}{*}{ Gage } & \multicolumn{9}{|c|}{ Original Raw Data $(\mathrm{N}=1,300,000)$} \\
\cline { 2 - 14 } & $\mathrm{P}=0.00 \mathrm{k}$ & $\mathrm{P}=9.25 \mathrm{k}$ & $\mathrm{P}=18.50 \mathrm{k}$ & $\mathrm{P}=27.75 \mathrm{k}$ & $\mathrm{P}=37.00 \mathrm{k}=46.25 \mathrm{k}=55.50 \mathrm{k}$ & $\mathrm{P}=64.75 \mathrm{k}$ & $\mathrm{P}=74.00 \mathrm{k}$ & $\mathrm{P}=83.25 \mathrm{k}$ & $\mathrm{P}=92.50 \mathrm{k}$ \\
\hline G01 & 0 & -14.8263 & -25.2354 & -31.5505 & -30.823 & -27.4707 & -23.4286 & -18.372 & -13.3183 & -7.0154 & -0.719 \\
\hline G02 & 0 & 16.2471 & 27.6978 & 42.7887 & 62.9083 & 85.2406 & 107.1639 & 130.2837 & 153.6814 & 177.9445 & 201.8063 \\
\hline G03 & 0 & 49.9414 & 85.3851 & 121.9397 & 160.2531 & 198.661 & 236.1945 & 274.7026 & 313.0695 & 351.6243 & 389.9988 \\
\hline G04 & 0 & 100.447 & 171.5705 & 240.0109 & 304.6523 & 367.5838 & 428.8973 & 489.8463 & 550.3848 & 614.3229 & 674.1794 \\
\hline G05 & 0 & 99.5568 & 170.4754 & 238.5235 & 303.4685 & 366.4241 & 428.4579 & 489.8951 & 551.805 & 612.7926 & 674.0201 \\
\hline G06 & 0 & 95.7808 & 163.8122 & 227.919 & 289.3646 & 349.131 & 408.1553 & 466.8586 & 525.2407 & 583.5829 & 642.2127 \\
\hline G07 & 0 & 30.7773 & 47.2727 & 63.9085 & 80.6886 & 97.2359 & 112.5771 & 128.9422 & 144.7487 & 163.5629 & 179.2261 \\
\hline G08 & 0 & 15.7975 & 28.0971 & 44.3242 & 64.2673 & 86.178 & 107.6453 & 129.6079 & 152.4622 & 179.0152 & 201.9047 \\
\hline G09 & 0 & -15.8855 & -25.1915 & -27.6894 & -23.5253 & -17.0478 & -10.7989 & -3.2544 & 4.6098 & 13.4992 & 22.1066 \\
\hline G10 & 0 & -13.9922 & 2.8251 & 5.5391 & 30.1152 & 55.2004 & 69.2869 & 83.8794 & 96.5757 & 109.1346 & 118.9611 \\
\hline G11 & 0 & 25.5815 & 41.3288 & 59.5754 & 80.5058 & 102.8259 & 124.8726 & 147.5222 & 170.3559 & 193.7015 & 216.3969 \\
\hline G12 & 0 & 63.1332 & 106.8911 & 152.069 & 198.0837 & 243.6817 & 288.2289 & 333.6949 & 378.8862 & 423.562 & 468.4804 \\
\hline G13 & 0 & 63.0495 & 109.4726 & 154.1395 & 197.0032 & 238.7119 & 280.0065 & 321.2584 & 363.1627 & 404.9315 & 445.7303 \\
\hline G14 & 0 & 99.2763 & 171.3546 & 240.4238 & 306.6224 & 370.6455 & 433.6084 & 496.6256 & 559.3715 & 621.4283 & 684.4225 \\
\hline G15 & 0 & 97.1262 & 166.9575 & 233.1812 & 296.584 & 358.0465 & 418.2642 & 478.6745 & 539.2315 & 610.3773 & 670.1147 \\
\hline G16 & 0 & 60.437 & 102.821 & 144.6539 & 187.7396 & 230.3189 & 272.8126 & 315.3543 & 358.3585 & 402.0647 & 445.0778 \\
\hline G17 & 0 & 23.8501 & 40.538 & 60.2314 & 83.3963 & 107.8572 & 132.0428 & 156.7847 & 182.4987 & 208.0821 & 233.5665 \\
\hline G18 & 0 & 12.728 & 20.3494 & 28.9367 & 38.8308 & 48.6306 & 58.3812 & 68.6951 & 79.6676 & 90.4891 & 101.4166 \\
\hline
\end{tabular}

\begin{tabular}{|c|c|c|c|c|c|c|c|c|c|c|c|c|}
\hline \multirow{2}{*}{ Gage } & \multicolumn{9}{|c|}{ Original Raw Data ( $=1,500,000)$} \\
\cline { 2 - 13 } & $\mathrm{P}=0.00 \mathrm{k}$ & $\mathrm{P}=9.25 \mathrm{k}$ & $\mathrm{P}=18.50 \mathrm{k}$ & $\mathrm{P}=27.75 \mathrm{k}$ & $\mathrm{P}=37.00 \mathrm{k}$ & $\mathrm{P}=46.25 \mathrm{k}=55.50 \mathrm{k}$ & $\mathrm{P}=64.75 \mathrm{k}$ & $\mathrm{P}=74.00 \mathrm{k}$ & $\mathrm{P}=83.25 \mathrm{k}$ & $\mathrm{P}=92.50 \mathrm{k}$ \\
\hline G01 & 0 & -13.9063 & -24.6845 & -32.061 & -32.2175 & -29.3421 & -24.8867 & -20.1567 & -14.4592 & -8.1609 & -1.8155 \\
\hline G02 & 0 & -6.5763 & -104.766 & -113.854 & -160.684 & -121.03 & -108.388 & -192.038 & -201.304 & -184.102 & -128.754 \\
\hline G03 & 0 & 48.3479 & 84.0817 & 121.2014 & 160.8248 & 200.5867 & 238.8709 & 277.6676 & 315.9082 & 354.8457 & 392.3052 \\
\hline G04 & 0 & 94.7797 & 164.4019 & 234.173 & 297.2168 & 358.921 & 419.0527 & 478.1691 & 536.6416 & 595.1678 & 653.3751 \\
\hline G05 & 0 & 95.5257 & 166.6361 & 235.6196 & 300.5707 & 363.578 & 425.5708 & 487.3396 & 548.6041 & 609.783 & 670.6442 \\
\hline G06 & 0 & 91.564 & 159.3117 & 224.1186 & 285.2335 & 344.6231 & 403.7852 & 462.1582 & 520.3969 & 578.3617 & 636.6609 \\
\hline G07 & 0 & 26.4083 & 42.4546 & 57.0073 & 71.0015 & 86.2121 & 101.2368 & 115.0987 & 130.6373 & 146.1765 & 160.4105 \\
\hline G08 & 0 & 14.6261 & 26.8348 & 42.7807 & 62.0795 & 84.0363 & 104.9221 & 127.2069 & 149.8605 & 172.8015 & 195.8349 \\
\hline G09 & 0 & -15.4259 & -25.105 & -27.9303 & -24.2744 & -18.2124 & -11.037 & -3.6773 & 4.3296 & 12.5208 & 21.3173 \\
\hline G10 & 0 & -10.0039 & -18.7022 & -24.0297 & -22.1038 & -17.0365 & -10.6765 & -4.0395 & 3.4751 & 10.5728 & 18.1309 \\
\hline G11 & 0 & 23.746 & 39.6388 & 56.878 & 77.4026 & 99.1317 & 121.2318 & 143.4707 & 167.0551 & 190.1287 & 213.2503 \\
\hline G12 & 0 & 60.4425 & 104.0743 & 149.6917 & 195.3154 & 240.5187 & 285.8236 & 330.6708 & 376.0306 & 421.1123 & 466.1066 \\
\hline G13 & 0 & 58.8954 & 102.5963 & 144.6329 & 184.3087 & 222.8289 & 260.8884 & 298.719 & 336.8305 & 374.9451 & 413.1088 \\
\hline G14 & 0 & 95.1608 & 166.9845 & 237.1465 & 302.9992 & 367.235 & 430.271 & 493.0825 & 555.6232 & 618.1718 & 680.5421 \\
\hline G15 & 0 & 93.1809 & 162.7305 & 229.2287 & 292.2573 & 353.392 & 413.5134 & 473.3175 & 533.4529 & 592.9931 & 652.4934 \\
\hline G16 & 0 & 57.6563 & 100.0803 & 142.283 & 184.6743 & 227.1594 & 269.3717 & 312.0945 & 354.8675 & 398.1086 & 441.0269 \\
\hline G17 & 0 & 22.6032 & 39.2912 & 58.3344 & 80.8965 & 104.709 & 129.4468 & 154.4658 & 179.7126 & 205.3794 & 231.0015 \\
\hline G18 & 0 & 11.4595 & 18.8955 & 26.9699 & 35.8806 & 45.4933 & 55.2433 & 65.4654 & 76.156 & 87.2705 & 98.3865 \\
\hline
\end{tabular}




\begin{tabular}{|c|c|c|c|c|c|c|c|c|c|c|c|c|}
\hline \multirow{2}{*}{ Gage } & \multicolumn{10}{|c|}{ Original Raw Data $(\mathrm{N}=1,700,000)$} \\
\cline { 2 - 14 } & $\mathrm{P}=0.00 \mathrm{k}$ & $\mathrm{P}=9.25 \mathrm{k}$ & $\mathrm{P}=18.50 \mathrm{k}$ & $\mathrm{P}=27.75 \mathrm{k}$ & $\mathrm{P}=37.00 \mathrm{k}$ & $\mathrm{P}=46.25 \mathrm{k}=55.50 \mathrm{k}$ & $\mathrm{P}=64.75 \mathrm{k}$ & $\mathrm{P}=74.00 \mathrm{k}$ & $\mathrm{P}=83.25 \mathrm{k}$ & $\mathrm{P}=92.50 \mathrm{k}$ \\
\hline G01 & 0 & -15.6069 & -26.4283 & -34.079 & -34.1244 & -31.141 & -26.6854 & -21.9989 & -16.1948 & -9.716 & -3.4651 \\
\hline G02 & 0 & 14.3652 & 25.6281 & 39.6107 & 58.7183 & 80.2717 & 102.704 & 125.5504 & 149.0443 & 173.3246 & 197.3296 \\
\hline G03 & 0 & 46.8138 & 82.4494 & 118.7365 & 156.365 & 194.3673 & 232.7406 & 270.7002 & 309.3559 & 348.0582 & 386.6272 \\
\hline G04 & 0 & 95.7038 & 167.5985 & 236.623 & 301.8941 & 364.9897 & 427.1638 & 487.6263 & 548.0953 & 609.0368 & 669.1493 \\
\hline G05 & 0 & 95.2897 & 167.1864 & 235.8886 & 300.9759 & 363.3772 & 425.4602 & 486.9934 & 548.3019 & 609.8972 & 671.2207 \\
\hline G06 & 0 & 91.7982 & 160.2481 & 225.2886 & 286.7317 & 346.2152 & 405.6115 & 463.3285 & 521.9425 & 580.7038 & 638.8629 \\
\hline G07 & 0 & 27.821 & 46.664 & 77.6889 & 96.5442 & 113.1406 & 130.5854 & 156.9792 & 178.8961 & 195.4821 & 211.3693 \\
\hline G08 & 0 & 13.8693 & 26.5823 & 42.2399 & 61.9358 & 82.6759 & 104.3498 & 126.434 & 148.8016 & 171.9993 & 194.9764 \\
\hline G09 & 0 & -16.7646 & -27.1383 & -30.1472 & -26.8631 & -20.8 & -13.7207 & -6.7305 & 1.1828 & 10.1115 & 18.6764 \\
\hline G10 & 0 & -8.8872 & -16.012 & -21.1028 & -19.7289 & -14.6632 & -7.566 & -0.2803 & 8.0678 & 15.9473 & 24.1562 \\
\hline G11 & 0 & 23.1 & 39.0404 & 55.8622 & 76.3864 & 97.7896 & 120.3504 & 142.6358 & 165.1992 & 188.5038 & 211.3494 \\
\hline G12 & 0 & 60.7059 & 105.8584 & 151.1258 & 197.2371 & 242.2588 & 287.4328 & 332.0154 & 377.2922 & 423.1037 & 467.8435 \\
\hline G13 & 0 & 56.9775 & 100.9315 & 143.0352 & 183.4262 & 223.0784 & 261.945 & 300.8615 & 339.6415 & 378.3321 & 417.9532 \\
\hline G14 & 0 & 94.9311 & 167.8243 & 237.0596 & 303.1462 & 367.2442 & 430.2818 & 492.6767 & 555.5443 & 618.5589 & 681.21 \\
\hline G15 & 0 & 92.1409 & 163.1481 & 229.3873 & 292.6659 & 353.5397 & 414.0957 & 474.1952 & 534.7195 & 595.2512 & 654.8155 \\
\hline G16 & 0 & 57.1593 & 99.8662 & 141.7475 & 183.9103 & 226.4943 & 269.0769 & 311.1542 & 354.1597 & 397.9527 & 441.0146 \\
\hline G17 & 0 & 21.0337 & 37.5337 & 56.6273 & 78.8661 & 102.4476 & 127.4639 & 152.0192 & 177.3606 & 203.6275 & 229.3424 \\
\hline G18 & 0 & 10.8019 & 17.9993 & 25.6946 & 34.7909 & 44.35 & 54.5166 & 64.4041 & 74.8083 & 86.5717 & 97.2126 \\
\hline
\end{tabular}

\begin{tabular}{|c|c|c|c|c|c|c|c|c|c|c|c|}
\hline \multirow{2}{*}{ Gage } & \multicolumn{11}{|c|}{ Original Raw Data $(\mathrm{N}=1,900,000)$} \\
\hline & $P=0.00 k$ & $P=9.25 \mathrm{k}$ & $P=18.50 \mathrm{~K}$ & $P=27.75 k$ & $P=37.00 \mathrm{k}$ & $P=46.25 \mathrm{k}$ & $P=55.50 k$ & $P=64.75 \mathrm{k}$ & $P=74.00 k$ & $P=83.25 k$ & $P=92.50 k$ \\
\hline G01 & 0 & -17.31 & -29.1879 & -38.4917 & -40.5749 & -38.1904 & -34.3339 & -29.5558 & -24.1772 & -18.1539 & -12.087 \\
\hline $\mathrm{G} 02$ & 0 & 14.6839 & 25.6284 & 38.4597 & 56.6431 & 77.8248 & 100.025 & 122.8219 & 146.3166 & 170.0862 & 194.3662 \\
\hline G03 & 0 & 49.6269 & 85.2116 & 121.5388 & 159.2552 & 197.6676 & 235.9898 & 274.1294 & 312.6412 & 351.5727 & 389.8114 \\
\hline G04 & 0 & 101.4754 & 174.6473 & 244.1611 & 310.6191 & 374.4849 & 437.058 & 499.1742 & 560.4615 & 621.3382 & 682.2688 \\
\hline G05 & 0 & 100.7152 & 173.2574 & 242.5587 & 308.8963 & 372.5012 & 434.6273 & 496.8076 & 558.2516 & 619.7034 & 680.9768 \\
\hline G06 & 0 & 96.4817 & 165.9163 & 232.0363 & 294.2774 & 354.8399 & 414.0043 & 473.2695 & 531.8855 & 590.649 & 648.7635 \\
\hline G07 & 0 & 33.0108 & 51.6747 & 69.8837 & 87.493 & 104.9642 & 122.0214 & 139.4074 & 157.0753 & 175.3514 & 1631 \\
\hline G08 & 0 & 14.458 & 25.0 & 40.1884 & 58.9269 & & 101. & 6665 & & 168.6348 & 607 \\
\hline G09 & 0 & -17.3189 & -29.774 & -34.1259 & -32.05 & -26.4 & & & & 4414 & 584 \\
\hline G10 & 0 & -12. & -22 & 735 & -30.9504 & -27.2538 & 4245 & & & 4146 & 8.8433 \\
\hline G1 & & & & 655 & & & & 336 & 534 & 186.7999 & 209.6831 \\
\hline G1 & & & 107. & 1782 & 197.7197 & 243.2553 & 4245 & 458 & 7708 & 4006 & 468.5458 \\
\hline G13 & 0 & & 107. & 7694 & 193.7 & 234.9936 & 275.4982 & 315.7747 & 0739 & .0524 & 439.7759 \\
\hline G14 & 0 & 99.92 & & 7526 & 310.7365 & 375.2674 & 438.9232 & 502.216 & 7722 & 527.8486 & 690.0951 \\
\hline G15 & 0 & 97.8367 & 168.7455 & 237.2523 & 301.5003 & 363.6228 & 424.6389 & 485.5227 & & 606.6637 & 667.1525 \\
\hline G16 & 0 & 59.8914 & 102.1869 & 144.3002 & 186.6041 & 228.7708 & 271.3584 & 314.1349 & 357.0979 & 399.786 & 443.1759 \\
\hline G17 & c & 23. & 38.5 & 56.6622 & 78.7 & 102.1518 & 126.4701 & 4359 & 4958 & 201.9729 & 227.7297 \\
\hline G18 & 0 & 11.8365 & 18.1465 & 25.657 & 34.2367 & 43.1868 & 2.885 & 63.1922 & 73.6898 & 83.9069 & 95.481 \\
\hline
\end{tabular}




\begin{tabular}{|c|c|c|c|c|c|c|c|c|c|c|c|}
\hline \multirow{2}{*}{ Gage } & \multicolumn{11}{|c|}{ Original Raw Data $(N=2,100,000)$} \\
\hline & $P=0.00 k$ & $P=9.25 \mathrm{k}$ & $P=18.50 \mathrm{k}$ & $P=27.75 k$ & $P=37.00 k$ & $P=46.25 k$ & $P=55.50 \mathrm{k}$ & $P=64.75 \mathrm{k}$ & $P=74.00 k$ & $P=83.25 k$ & $P=92.50 k$ \\
\hline G01 & 0 & -17.7238 & -30.6619 & -40.709 & -42.6953 & -40.2213 & -36.1361 & -31.5896 & -26.4451 & -19.6421 & -14.3121 \\
\hline 02 & 0 & .7244 & 25.5709 & 38.1238 & 56.6747 & 77.6214 & 100.0 & 122.3376 & 145.4145 & 169.1347 & \\
\hline $\mathrm{G} 03$ & 0 & 397 & 84.8779 & 120.78 & 158.5002 & 196.7701 & 235.2 & 273.5461 & 312.0556 & 350.6581 & \\
\hline G04 & 0 & 1278 & 174.7343 & 245.0537 & 311.6667 & 376.105 & 438.5 & 501.0093 & 562. & 035 & \\
\hline G05 & 0 & 100 & 173. & 243. & 309. & 372.6644 & & 496 & 558. & 002 & \\
\hline G06 & 0 & 96.5054 & 165.7035 & 232.0092 & 294.299 & 354.2563 & 413.4245 & 472.1787 & 531.0336 & 589.7545 & \\
\hline G07 & 0 & 28.7195 & 47.2737 & 64.5754 & 82.8415 & 100.683 & 116.988 & 135.441 & 153.9186 & 172.0078 & 187.873 \\
\hline G08 & 0 & 14.4276 & 24.8435 & 39.1497 & 57.8296 & 78.6986 & 100.1375 & 122.5379 & 144.6678 & 167.357 & 190.1854 \\
\hline G09 & 0 & -18.0638 & -30.706 & -35.5675 & -33.5328 & -28.1215 & -21.1336 & -13.8708 & -6.0487 & 2.0948 & 9.7284 \\
\hline G10 & 0 & 191.4719 & 140.8971 & 105.1777 & 178.2823 & 144.2137 & 95.0897 & 64.2476 & -240.168 & -244.814 & -258.842 \\
\hline G11 & 0 & 24.4758 & 40.1752 & 56.5745 & 76.3495 & 97.8855 & 120.3439 & 142.8982 & 165.6853 & 189.1209 & 211.8193 \\
\hline G12 & 0 & 62.5798 & 107.1007 & 151.6136 & 197.0443 & 242.3066 & 287.5628 & 333.3644 & 378.0576 & 423.3377 & 468.1445 \\
\hline G13 & 0 & 61.7757 & 108.4023 & 151.742 & 194.0658 & 235.2342 & 275.71 & 316.9314 & 357.6921 & \begin{tabular}{|l|}
399.1057 \\
\end{tabular} & \begin{tabular}{|l|l|}
440.0588 \\
\end{tabular} \\
\hline G14 & 0 & 100.1222 & 173.8336 & 244.2106 & 311.1594 & 375.8402 & 439.5536 & 502.9025 & 565.6559 & 628.7884 & 690.6273 \\
\hline G15 & 0 & 97.562 & 169.0767 & 236.8436 & 301.141 & 363.6358 & 424.6548 & 486.0984 & 546.157 & 606.6405 & 666.9459 \\
\hline G16 & 0 & 59.6106 & 102.227 & 143.8762 & 185.9944 & 228.4383 & 270.7454 & 313.7499 & 356.4352 & 399.4458 & 442.091 \\
\hline G17 & 0 & 22.7436 & 38.1363 & 56.1186 & 77.7089 & 101.1983 & 125.612 & 150.4885 & 175.416 & 201.0348 & 226.1031 \\
\hline G18 & 0 & 11.2242 & 17.4426 & 24.3418 & 33.0116 & 42.2435 & 52.3589 & 62.5225 & 72.2663 & 83.3703 & 94.0553 \\
\hline
\end{tabular}

\begin{tabular}{|c|c|c|c|c|c|c|c|c|c|c|c|c|}
\hline \multirow{2}{*}{ Gage } & \multicolumn{10}{|c|}{ Original Raw Data ( $=2,300,000)$} \\
\cline { 2 - 13 } & $\mathrm{P}=0.00 \mathrm{k}$ & $\mathrm{P}=9.25 \mathrm{k}$ & $\mathrm{P}=18.50 \mathrm{k}$ & $\mathrm{P}=27.75 \mathrm{k}$ & $\mathrm{P}=37.00 \mathrm{k}=46.25 \mathrm{k}$ & $\mathrm{P}=55.50 \mathrm{k}$ & $\mathrm{P}=64.75 \mathrm{k}$ & $\mathrm{P}=74.00 \mathrm{k}$ & $\mathrm{P}=83.25 \mathrm{k}$ & $\mathrm{P}=92.50 \mathrm{k}$ \\
\hline G01 & 0 & -17.6305 & -30.3831 & -40.3821 & -43.291 & -41.4118 & -38.059 & -33.462 & -28.0371 & -22.4756 & -17.0959 \\
\hline G02 & 0 & 13.5325 & 23.8329 & 35.374 & 52.9569 & 73.8598 & 96.1084 & 118.9965 & 142.1684 & 166.0762 & 189.9825 \\
\hline G03 & 0 & 48.2974 & 83.4756 & 119.2542 & 156.794 & 195.0293 & 233.3141 & 271.1397 & 309.5688 & 347.9958 & 386.3387 \\
\hline G04 & 0 & 99.375 & 172.5724 & 243.2715 & 310.4032 & 374.0124 & 436.1891 & 497.63 & 558.5204 & 619.6044 & 679.1609 \\
\hline G05 & 0 & 98.9517 & 171.7267 & 241.7716 & 308.2954 & 371.7147 & 433.9344 & 495.6038 & 557.1878 & 618.5471 & 679.1236 \\
\hline G06 & 0 & 95.4494 & 165.1637 & 231.5629 & 294.4582 & 354.4104 & 413.105 & 471.9468 & 530.1401 & 588.7616 & 646.6866 \\
\hline G07 & 0 & 28.5138 & 44.9087 & 60.2725 & 76.2226 & 92.1148 & 107.5208 & 123.0118 & 138.8955 & 156.1472 & 172.1566 \\
\hline G08 & 0 & 13.3019 & 23.1122 & 36.5649 & 54.1703 & 75.612 & 96.277 & 118.2208 & 140.2624 & 163.1367 & 186.0545 \\
\hline G09 & 0 & -18.5308 & -33.447 & -39.4229 & -38.405 & -33.4092 & -27.3457 & -20.4491 & -12.9946 & -5.1301 & 2.6478 \\
\hline G10 & 0 & -13.0074 & -24.0653 & -33.0858 & -33.5123 & -29.0441 & -22.172 & -15.72 & -8.7114 & -0.1815 & 8.3979 \\
\hline G11 & 0 & 23.3702 & 38.7952 & 54.0861 & 73.1688 & 94.4262 & 116.2383 & 138.7 & 161.2079 & 184.3179 & 206.7836 \\
\hline G12 & 0 & 61.4305 & 105.9365 & 150.4037 & 196.0696 & 241.4241 & 286.2547 & 331.621 & 376.9151 & 422.1489 & 466.3594 \\
\hline G13 & 0 & 60.2476 & 105.5771 & 149.4737 & 191.8905 & 231.9002 & 271.4493 & 310.9551 & 350.6499 & 390.7186 & 431.0225 \\
\hline G14 & 0 & 98.7227 & 171.8722 & 243.7776 & 311.2798 & 376.3752 & 439.2942 & 502.7792 & 565.2962 & 628.4717 & 690.1205 \\
\hline G15 & 0 & 96.3327 & 167.7707 & 236.3883 & 301.0719 & 363.3497 & 423.7324 & 484.0295 & 544.5659 & 605.2028 & 664.4075 \\
\hline G16 & 0 & 58.8652 & 100.8284 & 142.7957 & 184.8145 & 227.3466 & 269.3748 & 311.8166 & 354.5886 & 397.5927 & 439.586 \\
\hline G17 & 0 & 21.8651 & 36.0998 & 53.5256 & 74.4667 & 97.8165 & 121.5836 & 146.0415 & 171.3827 & 196.7218 & 221.5569 \\
\hline G18 & 0 & 10.8105 & 16.8933 & 23.6586 & 32.0528 & 40.9125 & 50.1458 & 60.3625 & 70.8135 & 81.2655 & 91.9091 \\
\hline
\end{tabular}




\begin{tabular}{|c|c|c|c|c|c|c|c|c|c|c|c|}
\hline \multirow{2}{*}{ Gage } & \multicolumn{11}{|c|}{ Original Raw Data $(\mathrm{N}=2,500,000)$} \\
\hline & $P=0.00 k$ & $P=9.25 \mathrm{k}$ & $P=18.50 k$ & $P=27.75 k$ & $P=37.00 k$ & $P=46.25 \mathrm{k}$ & $P=55.50 k$ & $P=64.75 \mathrm{k}$ & $P=74.00 k$ & $P=83.25 k$ & $P=92.50 k$ \\
\hline $\mathrm{G} 01$ & 0 & 19.3352 & -32.5024 & -43.9322 & -47.6671 & -45.8783 & -42.9867 & -38.3421 & -33.6998 & -28.1341 & -22.3881 \\
\hline $\mathrm{G02}$ & 0 & .1261 & 22.8287 & 4.2826 & 2.1899 & 72.9549 & 95.2916 & 117.7645 & 141.2104 & 165.3023 & 141.8028 \\
\hline G03 & & 7.9306 & 83.3839 & 119.0723 & 156.5629 & 194.612 & 232.7089 & 270.5784 & 309.0033 & 347.526 & 385.9554 \\
\hline G04 & $\mathrm{c}$ & 100.3945 & 173.219 & 243.6845 & 311.3258 & 375.1196 & 437.853 & 499.4318 & 560.4142 & 620.8461 & 680.3086 \\
\hline G05 & & 99.8825 & 172.3807 & 242.7989 & 309.5102 & 373.3959 & 435.5703 & 497.7524 & 558.9662 & 620.2339 & 680.9046 \\
\hline G06 & 0 & 96.4376 & 166.1092 & 233.2144 & 295.5044 & 355.5068 & 414.9075 & 473.425 & 531.6682 & 590.2931 & 648.456 \\
\hline G07 & 0 & 28.6856 & 46.0731 & 61.2279 & 75.2183 & 92.0518 & 108.2817 & 124.8411 & 141.8201 & 158.427 & 187.578 \\
\hline G08 & 0 & 11.805 & 20.5585 & 33.4716 & 52.0278 & 72.9385 & 94.2697 & 116.6731 & 138.7594 & \begin{tabular}{|l|l|}
161.4023 \\
\end{tabular} & 184.2802 \\
\hline G09 & 0 & -20.2851 & -35.6601 & -43.5326 & -43.3512 & -37.9837 & -31.2273 & -23.9614 & -17 & -9.152 & -0.9602 \\
\hline G10 & 0 & -14.704 & -28.8979 & -41.2801 & -44.2463 & -38.9022 & -28.6615 & -19.4392 & -10.6333 & 11.9446 & -12.8035 \\
\hline G11 & 0 & 23.0976 & 38.1097 & 53.0802 & 71.4278 & 92.6391 & 114.4994 & 136.8691 & 159.0533 & 181.7978 & 204.6323 \\
\hline G12 & 0 & 62.3867 & 106.6907 & 151.2043 & 196.941 & 242.4415 & 287.7522 & 332.7383 & 377.5204 & 422.4853 & 467.0559 \\
\hline G13 & 0 & 61.6679 & 106.661 & 150.4533 & 192.1174 & 233.1362 & 274.4366 & 314.6275 & 354.868 & 395.2974 & 436.1937 \\
\hline G14 & 0 & 99.8293 & 173.2516 & 244.7798 & 312.6949 & 377.7848 & 441.7217 & 504.6441 & 567.4815 & \begin{tabular}{|l|l|}
630.0944 \\
\end{tabular} & 692.2034 \\
\hline G15 & 0 & 96.8318 & 167.8904 & 236.4541 & 301.5009 & 363.7719 & 424.9833 & \begin{tabular}{|l}
485.5987 \\
\end{tabular} & 545.6179 & 605.5052 & 665.8171 \\
\hline G16 & 0 & 58.2665 & 100.2296 & 141.7353 & 184.1697 & 226.5153 & 269.2337 & 311.4906 & 354.449 & 397.3145 & 440.0911 \\
\hline G17 & 0 & .666 & 34.4394 & 50.8975 & 71.9334 & 95.1906 & 119.6043 & 144.2506 & 169.0832 & 194.3351 & 219.9095 \\
\hline G18 & 0 & 10.111 & 16.2897 & 22.1663 & 30.7956 & 39.6076 & 48.9785 & 59.1474 & 69.0359 & 79.3952 & 90.5986 \\
\hline
\end{tabular}

\begin{tabular}{|c|c|c|c|c|c|c|c|c|c|c|c|c|c|}
\hline \multirow{2}{*}{ Gage } & \multicolumn{10}{|c|}{ Original Raw Data $(\mathrm{N}=2,700,000)$} \\
\cline { 2 - 13 } & $\mathrm{P}=0.00 \mathrm{k}$ & $\mathrm{P}=9.25 \mathrm{k}$ & $\mathrm{P}=18.50 \mathrm{k}=27.75 \mathrm{~K}$ & $\mathrm{P}=37.00 \mathrm{k}$ & $\mathrm{P}=46.25 \mathrm{k}$ & $\mathrm{P}=55.50 \mathrm{k}$ & $\mathrm{P}=64.75 \mathrm{k}$ & $\mathrm{P}=74.00 \mathrm{k}$ & $\mathrm{P}=83.25 \mathrm{k}$ & $\mathrm{P}=92.50 \mathrm{k}$ \\
\hline G01 & 0 & 9.25 & 18.5 & 27.75 & 37 & 46.25 & 55.5 & 64.75 & 74 & 83.25 & 92.5 \\
\hline G02 & 0 & -19.3289 & -33.9497 & -45.8816 & -50.355 & -48.5208 & -45.1246 & -40.7134 & -35.7967 & -30.2347 & -23.7517 \\
\hline G03 & 0 & 12.7862 & -47.407 & -34.5206 & -17.9672 & 2.7879 & 25.4397 & 48.4966 & 78.204 & 103.0314 & 127.2137 \\
\hline G04 & 0 & 48.8929 & 84.2959 & 120.1199 & 157.4702 & 195.5158 & 233.8382 & 272.0746 & 310.4488 & 348.9666 & 387.4371 \\
\hline G05 & 0 & 102.2945 & 176.0318 & 247.457 & 315.8704 & 380.2029 & 443.7534 & 506.1959 & 568.2269 & 629.4754 & 690.8249 \\
\hline G06 & 0 & 100.5401 & 173.6943 & 244.3501 & 311.9495 & 375.3756 & 438.3919 & 500.5328 & 562.3558 & 623.3498 & 684.7693 \\
\hline G07 & 0 & 96.3826 & 166.3545 & 234.0437 & 297.5781 & 358.3593 & 417.9785 & 476.762 & 535.4118 & 594.0218 & 652.6387 \\
\hline G08 & 0 & 9.0083 & 28.0017 & 45.944 & 63.5638 & 82.065 & 100.9994 & 119.5804 & 139.0554 & 158.525 & 172.5233 \\
\hline G09 & 0 & 13.1533 & 20.4623 & 33.128 & 50.0234 & 70.1359 & 91.7807 & 113.5052 & 135.6674 & 158.2599 & 181.2725 \\
\hline G10 & 0 & -19.1283 & -35.2879 & -43.9489 & -44.8299 & -40.5755 & -33.9131 & -27.5757 & -20.1268 & -12.3084 & -3.8394 \\
\hline G11 & 0 & 595.893 & 54556.69 & 54610.42 & 13435.47 & 17705.62 & 54302.8 & 54345.29 & 54329.1 & 54316.82 & 54376.04 \\
\hline G12 & 0 & 23.3684 & 37.6848 & 52.4242 & 70.9991 & 91.4258 & 113.2872 & 135.4732 & 158.1679 & 181.0505 & 203.5622 \\
\hline G13 & 0 & 61.9591 & 105.7984 & 149.6426 & 195.0122 & 240.3977 & 285.4449 & 330.6657 & 375.6493 & 420.4542 & 465.4156 \\
\hline G14 & 0 & 62.4397 & 107.6065 & 152.7776 & 196.0993 & 237.5249 & 278.3051 & 319.5519 & 360.9415 & 402.4733 & 444.7039 \\
\hline G15 & 0 & 99.6369 & 173.3328 & 245.414 & 314.0676 & 379.0607 & 443.2721 & 506.2833 & 569.4884 & 631.9116 & 694.2029 \\
\hline G16 & 0 & 97.9281 & 169.717 & 238.9184 & 304.5112 & 366.7717 & 428.6229 & 489.6459 & 550.1198 & 610.8328 & 671.321 \\
\hline G17 & 0 & 58.501 & 100.0097 & 141.3366 & 183.0843 & 224.8827 & 267.4685 & 309.9664 & 352.8358 & 395.4762 & 438.4923 \\
\hline G18 & 0 & 21.6349 & 34.7158 & 50.9911 & 71.01 & 93.6673 & 117.8512 & 142.036 & 166.9595 & 192.1178 & 217.5079 \\
\hline
\end{tabular}




\begin{tabular}{|c|c|c|c|c|c|c|c|c|c|c|c|}
\hline \multirow{2}{*}{ Gage } & \multicolumn{10}{|c|}{ Original Raw Data (N=2,900,000) } \\
\cline { 2 - 14 } & $\mathrm{P}=0.00 \mathrm{k}$ & $\mathrm{P}=9.25 \mathrm{k}$ & $\mathrm{P}=18.50 \mathrm{k}$ & $\mathrm{P}=27.75 \mathrm{k}$ & $\mathrm{P}=37.00 \mathrm{k}$ & $\mathrm{P}=46.25 \mathrm{k}$ & $\mathrm{P}=55.50 \mathrm{k}$ & $\mathrm{P}=64.75 \mathrm{k}$ & $\mathrm{P}=74.00 \mathrm{k}$ & $\mathrm{P}=83.25 \mathrm{k}$ & $\mathrm{P}=92.50 \mathrm{k}$ \\
\hline G01 & 0 & -20.2625 & -35.2333 & -47.4905 & -52.2135 & -50.9453 & -47.8735 & -42.8753 & -37.785 & -32.1839 & -26.2145 \\
\hline G02 & 0 & 18.423 & 28.9301 & 40.0088 & 56.5964 & 77.3143 & 98.674 & 121.3398 & 144.2744 & 167.9136 & 191.6023 \\
\hline G03 & 0 & 49.4866 & 84.6093 & 120.4727 & 158.0029 & 196.413 & 234.2226 & 272.9134 & 311.2357 & 349.4252 & 388.1253 \\
\hline G04 & 0 & 103.2615 & 177.6896 & 249.9443 & 318.492 & 383.8881 & 446.6425 & 508.9866 & 570.6876 & 631.0476 & 692.2516 \\
\hline G05 & 0 & 102.3445 & 176.0978 & 247.3529 & 314.6694 & 379.0674 & 441.5218 & 503.984 & 565.4781 & 626.7471 & 688.0236 \\
\hline G06 & 0 & 97.9878 & 168.553 & 236.4584 & 299.7826 & 360.6321 & 419.755 & 478.9326 & 537.7416 & 596.6512 & 655.1463 \\
\hline G07 & 0 & 27.0286 & 44.0149 & 60.8637 & 77.3941 & 94.2041 & 110.2903 & 126.4545 & 143.1844 & 161.6578 & 180.085 \\
\hline G08 & 0 & 12.8603 & 21.3271 & 34.242 & 51.101 & 71.3463 & 92.188 & 114.0065 & 136.2995 & 158.7457 & 181.4738 \\
\hline G09 & 0 & -19.9238 & -36.5575 & -44.5277 & -45.458 & -41.0165 & -35.2319 & -28.1505 & -20.9309 & -13.4791 & -5.1469 \\
\hline G10 & 0 & 0 & 0 & -44858.7 & 0 & -51361 & 0 & 0 & 0 & 0 & 0 \\
\hline G11 & 0 & 22.7345 & 36.7318 & 50.6914 & 68.7212 & 89.2472 & 110.4696 & 132.0186 & 154.3996 & 176.8284 & 199.6724 \\
\hline G12 & 0 & 62.5725 & 106.1406 & 151.014 & 197.3039 & 242.9513 & 287.556 & 333.1366 & 377.6404 & 422.4217 & 467.3908 \\
\hline G13 & 0 & 60.3205 & 104.4178 & 147.2669 & 188.6819 & 228.0597 & 266.5588 & 305.4788 & 343.9841 & 383.6987 & 424.2049 \\
\hline G14 & 0 & 101.5179 & 175.8818 & 248.6767 & 317.0683 & 382.7271 & 446.3496 & 509.8409 & 572.8291 & 635.3131 & 697.9446 \\
\hline G15 & 0 & 99.3863 & 172.0257 & 241.7993 & 307.4523 & 370.0519 & 431.4985 & 492.6277 & 553.2073 & 613.8408 & 674.0634 \\
\hline G16 & 0 & 59.7471 & 101.7565 & 143.2166 & 184.6813 & 227.4944 & 269.4288 & 311.734 & 354.2749 & 397.2378 & 440.2948 \\
\hline G17 & 0 & 22.1951 & 35.046 & 51.2754 & 71.3916 & 94.3317 & 117.9645 & 142.5715 & 167.2233 & 191.9237 & 217.6892 \\
\hline G18 & 0 & 10.1026 & 15.4827 & 20.655 & 28.297 & 37.198 & 46.3306 & 55.9288 & 65.8104 & 76.1185 & 86.8927 \\
\hline
\end{tabular}




\section{Original RAW Data From Galvanized SteEl SPECimen}

\begin{tabular}{|c|c|c|c|c|c|c|c|c|c|c|c|}
\hline \multirow{2}{*}{ Gage } & \multicolumn{10}{|c|}{ Original Raw Data $(\mathrm{N}=0)$} \\
\cline { 2 - 13 } & $\mathrm{P}=0.00 \mathrm{k}$ & $\mathrm{P}=9.30 \mathrm{k}$ & $\mathrm{P}=18.60 \mathrm{k}$ & $\mathrm{P}=27.90 \mathrm{k}$ & $\mathrm{P}=37.20 \mathrm{k}$ & $\mathrm{P}=46.50 \mathrm{k}$ & $\mathrm{P}=55.80 \mathrm{k}$ & $\mathrm{P}=65.10 \mathrm{k}$ & $\mathrm{P}=74.40 \mathrm{k}$ & $\mathrm{P}=83.70 \mathrm{k}$ & $\mathrm{P}=93.00 \mathrm{k}$ \\
\hline G01 & 0 & 0.1371 & -1.4046 & -1.6435 & 1.0125 & 3.9408 & 7.3326 & 9.608 & 14.3618 & 18.4155 & 29.5738 \\
\hline G02 & 0 & 19.9219 & 33.0148 & 45.8308 & 59.6152 & 73.6278 & 87.1786 & 100.6378 & 114.3709 & 127.7806 & 141.467 \\
\hline G03 & 0 & 54.4659 & 94.4533 & 133.8436 & 173.1931 & 212.4057 & 252.2256 & 291.4497 & 330.7661 & 370.3652 & 410.0116 \\
\hline G04 & 0 & 93.2085 & 162.4181 & 229.4067 & 294.7319 & 359.9261 & 424.5246 & 488.2482 & 551.4686 & 614.7436 & 678.3981 \\
\hline G05 & 0 & 89.8304 & 155.3361 & 218.2539 & 279.3245 & 339.7532 & 399.2615 & 457.9422 & 516.4903 & 574.3955 & 632.5861 \\
\hline G06 & 0 & 89.5685 & 156.198 & 220.9774 & 283.9059 & 346.7029 & 408.7639 & 470.2744 & 531.0489 & 592.2489 & 652.8054 \\
\hline G07 & 0 & 51.0482 & 87.7082 & 126.5897 & 165.5664 & 205.3777 & 245.1942 & 284.5059 & 324.4218 & 364.1567 & 404.3109 \\
\hline G08 & 0 & 19.9838 & 32.9832 & 50.6105 & 70.6424 & 92.0623 & 114.0857 & 135.9727 & 158.3679 & 181.1343 & 203.9472 \\
\hline G09 & 0 & -8.2113 & -16.8818 & -18.8629 & -16.5117 & -12.7359 & -8.2239 & -3.014 & 2.8853 & 8.8288 & 15.0028 \\
\hline G10 & 0 & -1.3309 & -3.7298 & -3.7279 & -1.2296 & 2.282 & 6.4851 & 10.8287 & 16.3675 & 21.908 & 28.1386 \\
\hline G11 & 0 & 25.3921 & 43.2541 & 61.9059 & 80.6499 & 100.2719 & 119.85 & 139.9405 & 160.0737 & 180.2997 & 200.6195 \\
\hline G12 & 0 & 44.2846 & 74.9512 & 104.826 & 136.5674 & 170.9201 & 200.4278 & 231.7103 & 260.9882 & 290.5021 & 321.274 \\
\hline G13 & 0 & 90.3425 & 157.2284 & 219.7157 & 281.7939 & 342.5799 & 401.3777 & 460.2289 & 518.1126 & 575.1202 & 631.856 \\
\hline G14 & 0 & 91.9949 & 159.8548 & 225.9159 & 289.4356 & 353.5661 & 417.1484 & 479.9035 & 542.8523 & 606.5974 & 668.7734 \\
\hline G15 & 0 & 88.2067 & 153.861 & 217.2947 & 278.8327 & 340.3311 & 401.3265 & 461.818 & 521.945 & 581.7077 & 641.7095 \\
\hline G16 & 0 & 52.7642 & 90.7764 & 130.1363 & 169.1322 & 208.7322 & 248.6137 & 287.8504 & 327.2286 & 366.9791 & 406.7318 \\
\hline G17 & 0 & 25.5313 & 42.5337 & 62.5789 & 84.3356 & 106.6912 & 129.6948 & 152.1951 & 175.4776 & 198.8986 & 222.7359 \\
\hline G18 & 0 & 10.4083 & 16.4023 & 24.7995 & 33.387 & 42.3062 & 51.1327 & 59.7213 & 69.0671 & 78.2692 & 87.8961 \\
\hline
\end{tabular}

\begin{tabular}{|c|c|c|c|c|c|c|c|c|c|c|c|}
\hline \multirow{2}{*}{ Gage } & \multicolumn{9}{|c|}{ Original Raw Data $(\mathrm{N}=100,000)$} \\
\cline { 2 - 13 } & $\mathrm{P}=0.00 \mathrm{k}$ & $\mathrm{P}=9.30 \mathrm{k}$ & $\mathrm{P}=18.60 \mathrm{k}$ & $\mathrm{P}=27.90 \mathrm{k}$ & $\mathrm{P}=37.20 \mathrm{k}$ & $\mathrm{P}=46.50 \mathrm{k}$ & $\mathrm{P}=55.80 \mathrm{k}$ & $\mathrm{P}=65.10 \mathrm{k}$ & $\mathrm{P}=74.40 \mathrm{k}$ & $\mathrm{P}=83.70 \mathrm{k}$ & $\mathrm{P}=93.00 \mathrm{k}$ \\
\hline G01 & 0 & -5.2774 & -10.9245 & -14.5212 & -13.4071 & -11.6458 & -7.6392 & -3.7735 & 0.3708 & 5.9657 & 11.0914 \\
\hline G02 & 0 & 18.9645 & 31.5614 & 43.9676 & 57.7073 & 71.672 & 85.494 & 99.0416 & 112.5858 & 126.037 & 139.5363 \\
\hline G03 & 0 & 53.9216 & 92.8967 & 131.9257 & 171.3305 & 211.1983 & 251.1193 & 290.255 & 329.9948 & 369.2732 & 409.1131 \\
\hline G04 & 0 & 96.7219 & 168.2883 & 237.6356 & 304.205 & 369.3891 & 433.7453 & 497.0873 & 560.5772 & 623.7956 & 686.4181 \\
\hline G05 & 0 & 92.2497 & 160.5439 & 225.5089 & 287.6067 & 348.8307 & 408.8099 & 467.4041 & 526.0048 & 584.4274 & 642.3002 \\
\hline G06 & 0 & 92.5039 & 161.9274 & 228.7116 & 292.6224 & 355.7046 & 417.8186 & 478.7781 & 539.6977 & 600.5321 & 660.8619 \\
\hline G07 & 0 & 50.1665 & 86.1774 & 123.8063 & 163.2422 & 202.7261 & 242.3529 & 281.8469 & 321.6671 & 361.6763 & 401.5024 \\
\hline G08 & 0 & 16.4708 & 26.2322 & 40.5756 & 59.917 & 80.5964 & 102.2027 & 124.4607 & 147.3681 & 170.0907 & 192.861 \\
\hline G09 & 0 & -16.4226 & -31.2755 & -38.8385 & -39.2594 & -35.6672 & -31.8022 & -26.1341 & -21.5768 & -14.9417 & -9.9234 \\
\hline G10 & 0 & -8.1041 & -16.5855 & -21.3307 & -20.6312 & -17.578 & -13.1416 & -8.3851 & -2.382 & 4.1268 & 10.6342 \\
\hline G11 & 0 & 22.3884 & 37.3873 & 54.1423 & 72.5603 & 92.2738 & 112.494 & 132.3935 & 152.8012 & 173.7182 & 194.3112 \\
\hline G12 & 0 & 42.9834 & 73.9806 & 105.3953 & 136.4398 & 167.8561 & 199.2291 & 230.0006 & 261.9371 & 294.4804 & 325.5792 \\
\hline G13 & 0 & 93.5801 & 162.1764 & 228.9262 & 290.7674 & 352.0129 & 412.1059 & 470.9062 & 529.4351 & 587.414 & 644.842 \\
\hline G14 & 0 & 94.9169 & 165.9773 & 235.1467 & 300.6628 & 365.6772 & 429.4009 & 492.1129 & 554.832 & 617.2814 & 679.8306 \\
\hline G15 & 0 & 91.6025 & 159.8626 & 225.8559 & 289.4892 & 351.3652 & 413.2488 & 473.1882 & 533.5997 & 594.0184 & 655.6532 \\
\hline G16 & 0 & 52.3608 & 89.5023 & 128.3608 & 167.9203 & 207.2033 & 246.5367 & 285.78 & 325.1651 & 365.0134 & 404.5903 \\
\hline G17 & 0 & 22.0298 & 35.0247 & 52.7181 & 73.3666 & 95.3998 & 117.8496 & 140.8549 & 164.1809 & 187.7388 & 211.4341 \\
\hline G18 & 0 & 7.8725 & 11.7097 & 17.794 & 26.1004 & 34.5036 & 43.4707 & 52.485 & 61.9248 & 71.7386 & 81.6476 \\
\hline
\end{tabular}




\begin{tabular}{|c|c|c|c|c|c|c|c|c|c|c|c|}
\hline \multirow{2}{*}{ Gage } & \multicolumn{9}{|c|}{ Original Raw Data $(\mathrm{N}=200,000)$} \\
\cline { 2 - 13 } & $\mathrm{P}=0.00 \mathrm{k}$ & $\mathrm{P}=9.30 \mathrm{k}$ & $\mathrm{P}=18.60 \mathrm{k}$ & $\mathrm{P}=27.90 \mathrm{k}=37.20 \mathrm{k}$ & $\mathrm{P}=46.50 \mathrm{k}$ & $\mathrm{P}=55.80 \mathrm{k}$ & $\mathrm{P}=65.10 \mathrm{k}$ & $\mathrm{P}=74.40 \mathrm{k}$ & $\mathrm{P}=83.70 \mathrm{k}$ & $\mathrm{P}=93.00 \mathrm{k}$ \\
\hline G01 & 0 & -9.2429 & -19.0439 & -25.5325 & -25.6796 & -24.9432 & -21.3595 & -17.8224 & -12.3718 & -7.3847 & -2.2133 \\
\hline G02 & 0 & 18.6486 & 31.4401 & 43.2517 & 56.9025 & 70.7309 & 84.6949 & 98.5178 & 112.5226 & 126.3434 & 140.213 \\
\hline G03 & 0 & 53.159 & 91.6838 & 129.8723 & 168.8511 & 208.2976 & 247.9772 & 287.7999 & 327.8073 & 367.4963 & 407.7451 \\
\hline G04 & 0 & 98.6156 & 171.661 & 241.9769 & 308.3075 & 373.5785 & 438.2538 & 501.7756 & 565.5843 & 628.8433 & 692.5291 \\
\hline G05 & 0 & 93.7322 & 163.1387 & 229.4014 & 291.684 & 352.444 & 412.5624 & 471.6196 & 531.288 & 590.0354 & 649.2072 \\
\hline G06 & 0 & 94.1371 & 164.0313 & 231.6113 & 295.2953 & 357.6855 & 419.8045 & 481.047 & 542.112 & 603.1835 & 664.1236 \\
\hline G07 & 0 & 49.9536 & 85.6081 & 122.4652 & 160.9906 & 200.5385 & 240.3207 & 280.2464 & 320.3109 & 360.5208 & 400.5484 \\
\hline G08 & 0 & 14.2497 & 22.9043 & 35.0734 & 53.627 & 74.4963 & 96.1496 & 118.9635 & 141.9161 & 164.6859 & 187.5949 \\
\hline G09 & 0 & -18.4051 & -35.0545 & -45.2016 & -45.8493 & -43.2725 & -39.2206 & -33.2775 & -28.1209 & -21.993 & -15.3569 \\
\hline G10 & 0 & -11.5148 & -22.713 & -29.9888 & -30.6246 & -28.6293 & -24.2413 & -18.9752 & -12.516 & -5.5454 & 1.1008 \\
\hline G11 & 0 & 20.4959 & 33.742 & 48.8837 & 66.6603 & 85.4537 & 105.5401 & 125.7666 & 146.406 & 167.4203 & 188.4319 \\
\hline G12 & 0 & 44.0049 & 74.6271 & 105.8105 & 136.6212 & 167.0122 & 198.2441 & 229.8529 & 261.6438 & 292.8816 & 325.5187 \\
\hline G13 & 0 & 94.6634 & 164.1067 & 229.384 & 291.8858 & 352.8639 & 412.4102 & 471.825 & 530.1784 & 587.9816 & 646.0237 \\
\hline G14 & 0 & 96.5028 & 168.5441 & 237.8136 & 303.7542 & 368.1261 & 431.9499 & 494.8997 & 557.8585 & 620.2675 & 683.2877 \\
\hline G15 & 0 & 92.5339 & 162.0967 & 228.7429 & 291.9139 & 353.6529 & 415.0279 & 475.6201 & 535.8943 & 595.8043 & 656.6043 \\
\hline G16 & 0 & 51.7582 & 88.8557 & 126.7461 & 165.6116 & 204.7142 & 244.6512 & 284.0344 & 324.1602 & 363.8258 & 403.7716 \\
\hline G17 & 0 & 20.3284 & 31.9881 & 47.8912 & 68.3136 & 89.5232 & 112.4416 & 135.772 & 159.7041 & 183.3132 & 207.1528 \\
\hline G18 & 0 & 7.6374 & 10.3013 & 14.79 & 22.251 & 30.1864 & 38.7305 & 48.078 & 57.6129 & 67.2893 & 77.0101 \\
\hline
\end{tabular}

\begin{tabular}{|c|c|c|c|c|c|c|c|c|c|c|c|}
\hline \multirow{2}{*}{ Gage } & \multicolumn{11}{|c|}{ Original Raw Data $(\mathrm{N}=300,000)$} \\
\hline & $P=0.00 k$ & $P=9.30 k$ & $P=18.60 k$ & $P=27.90 k$ & $P=37.20 \mathrm{k}$ & $P=46.50 \mathrm{k}$ & $P=55.80 \mathrm{k}$ & $P=65.10 k$ & $P=74.40 \mathrm{k}$ & $P=83.70 k$ & $P=93.00 k$ \\
\hline G01 & 0 & -10.1012 & -18.5105 & -25.7543 & -25.8062 & -25.023 & -21.0106 & -14.3309 & \begin{tabular}{|l|}
-7.7461 \\
\end{tabular} & -1.2526 & 4.6767 \\
\hline G02 & 0 & 18.8405 & 31.9162 & 44.1082 & 57.3469 & 71.4088 & 85.191 & 99.0616 & 112.6541 & 126.1986 & 139.7951 \\
\hline G03 & 0 & 53.5445 & 92.4618 & 130.6536 & 169.9185 & 209.6943 & 249.4273 & 289.0229 & 328.8084 & 368.7837 & 408.2056 \\
\hline G04 & 0 & 99.6576 & 174.1586 & 246.7657 & 314.6906 & 380.7195 & 445.6419 & 509.9679 & 573.0471 & 636.3669 & 699.6949 \\
\hline G05 & 0 & 95.4434 & 166.0993 & 234.4002 & 298.1649 & 359.9436 & 420.3844 & 479.9984 & 538.7368 & 597.8534 & 656.3738 \\
\hline G06 & 0 & 95.1079 & 166.4856 & 235.7351 & 300.6716 & 363.8026 & 426.0588 & 487.8576 & 549.0121 & 609.8026 & 670.1351 \\
\hline G07 & 0 & 49.4322 & 85.4029 & 121.6494 & 160.3492 & 199.9341 & 239.8007 & 279.808 & 319.5886 & 359.837 & 399.6698 \\
\hline G08 & 0 & 13.5121 & 21.4246 & 32.1146 & 50.114 & \begin{tabular}{|l|}
70.7957 \\
\end{tabular} & 92.4978 & 114.9411 & 137.4781 & 160.3863 & 182.7396 \\
\hline G09 & 0 & -20.5704 & -37.0768 & -51.6982 & -54.2854 & -52.0325 & -48.9523 & -44.0262 & -38.2679 & -32.2806 & -26.3831 \\
\hline G10 & 0 & -13.4978 & -26.7696 & -36.8586 & -39.9833 & -38.5444 & -34.6138 & -29.6754 & -23.4425 & -17.1184 & -10.8878 \\
\hline G11 & 0 & 20.2207 & 33.0045 & 47.3128 & 64.7662 & 83.8354 & 103.6417 & 123.7244 & 144.5501 & 165.3739 & 186.0599 \\
\hline G12 & 0 & 43.0122 & 73.2476 & 104.6468 & 135.302 & 146.8568 & 169.0752 & 194.4015 & 220.2656 & 247.9969 & 278.1975 \\
\hline G13 & 0 & 96.9064 & 168.9262 & 238.7297 & 303.3007 & 365.2822 & 426.0644 & 485.7872 & 544.3101 & 602.6541 & 660.2157 \\
\hline G14 & 0 & 97.5293 & 171.1989 & 242.5607 & 309.4803 & 374.7391 & 439.0319 & 502.637 & 565.276 & 628.0158 & 690.1602 \\
\hline G15 & 0 & 93.8778 & 164.5067 & 233.4271 & 297.8049 & 360.5647 & 421.9385 & 483.7381 & 544.151 & 604.525 & 664.5344 \\
\hline G16 & 0 & 51.4286 & 88.3341 & 125.942 & 165.2202 & 204.5496 & 244.1114 & 284.085 & 323.6509 & 363.5418 & 403.3925 \\
\hline G17 & 0 & 19.9567 & 30.6928 & 45.1181 & 65.2172 & 86.702 & 108.9251 & 132.2033 & 156.0365 & 179.9683 & 203.992 \\
\hline G18 & 0 & 8.3927 & 10.8174 & 15.2599 & 21.9635 & 30.4124 & 39.1451 & 48.3474 & 57.9257 & 67.7416 & 77.5553 \\
\hline
\end{tabular}




\begin{tabular}{|c|c|c|c|c|c|c|c|c|c|c|c|}
\hline \multirow{2}{*}{ Gage } & \multicolumn{11}{|c|}{ Original Raw Data $(N=500,000)$} \\
\hline & $P=0.00 k$ & $P=9.30 \mathrm{k}$ & $P=18.60 k$ & $P=27.90 k$ & $P=37.20 \mathrm{k}$ & $P=46.50 \mathrm{k}$ & $P=55.80 \mathrm{k}$ & $P=65.10 k$ & $P=74.40 \mathrm{k}$ & $P=83.70 k$ & $P=93.00 k$ \\
\hline G01 & 0 & -12.3476 & -26.6612 & -37.5593 & -41.7307 & -40.9921 & -37.6438 & -35.0345 & -30.1818 & -25.3322 & -21.5102 \\
\hline $\mathrm{G} 02$ & 0 & 19.3098 & 32.7607 & 45.466 & 59.077 & 73.0481 & 87.4282 & 100.8392 & 114.7529 & 128.7611 & 142.5378 \\
\hline $\mathrm{G} 03$ & 0 & 53.5878 & 92.3243 & 131.3921 & 170.1874 & 209.8648 & 249.8148 & 288.9458 & 329.1419 & 368.7855 & 408.4342 \\
\hline G04 & 0 & 101.3544 & 178.1154 & 252.5653 & 321.4985 & 387.5604 & 452.9343 & 516.5039 & 580.1282 & 643.8071 & 707.1689 \\
\hline G05 & 0 & 96.5111 & 169.0228 & 239.5972 & 304.3381 & 365.9792 & 427.0251 & 487.0111 & 546.4946 & 606.0308 & 665.7596 \\
\hline G06 & 0 & 96.0851 & 168.8116 & 239.7356 & 305.2311 & 368.5036 & 430.8072 & 491.8631 & 553.2521 & 613.9971 & 674.9359 \\
\hline G07 & 0 & 49.4823 & 85.2236 & 121.2435 & 159.7171 & 199.1667 & 238.8982 & 278.2648 & 318.7431 & 358.9015 & 398.6934 \\
\hline G08 & 0 & 12.955 & 19.3861 & 28.5923 & 45.1514 & 65.3684 & 86.9267 & 108.9051 & 132.0866 & 154.8985 & 177.6191 \\
\hline G09 & 0 & -20.7945 & -40.7211 & -57.2341 & -60.6036 & -58.9511 & -54.9932 & -50.4794 & -44.6766 & $\mid-38.8272$ & -32.8367 \\
\hline G10 & 0 & -15.9422 & -32.5265 & -45.655 & -49.653 & -48.3496 & -44.699 & -39.7524 & -33.4291 & -27.2446 & -20.7827 \\
\hline G11 & 0 & 18.8777 & 30.1833 & 43.4791 & 60.0509 & 78.3792 & 98.3235 & 118.3152 & 139.0919 & 159.7761 & 180.5519 \\
\hline G12 & 0 & 43.7326 & 75.1177 & 106.0357 & 137.9807 & 168.906 & 200.7605 & 231.7382 & 263.6904 & 295.1325 & 327.2745 \\
\hline G13 & 0 & 96.7827 & 169.9736 & 240.5769 & 305.1123 & 366.6861 & 426.8285 & 486.0968 & 544.7224 & 603.7255 & 661.5749 \\
\hline G14 & 0 & 98.964 & 178.2418 & 250.7153 & 318.9792 & 384.0055 & 448.9007 & 513.9899 & 576.5359 & 639.4605 & 701.8366 \\
\hline G15 & 0 & 94.6694 & 166.6467 & 236.7767 & 301.9456 & 364.3824 & 426.1761 & 486.8625 & 547.2769 & 607.6991 & 667.9424 \\
\hline G16 & 0 & 51.9915 & 88.3465 & 125.2186 & 163.9916 & 203.1849 & 242.9347 & 282.3684 & 322.5392 & 362.3902 & 402.0122 \\
\hline G17 & 0 & 19.7271 & 29.7743 & 41.9448 & 61.0786 & 82.2475 & 105.0732 & 127.9023 & 151.6985 & 175.5412 & 199.5235 \\
\hline G18 & 0 & 8.8098 & 11.5679 & 14.0346 & 20.7387 & 28.8118 & 36.9767 & 45.5208 & 55.0513 & 65.0996 & 74.8662 \\
\hline
\end{tabular}

\begin{tabular}{|c|c|c|c|c|c|c|c|c|c|c|c|}
\hline \multirow{2}{*}{ Gage } & \multicolumn{11}{|c|}{ Original Raw Data $(N=700,000)$} \\
\hline & $P=0.00 k$ & $P=9.30 k$ & $P=18.60 k$ & $\mathrm{P}=27.90 \mathrm{k}$ & $P=37.20 \mathrm{k}$ & $P=46.50 k$ & $P=55.80 k$ & $P=65.10 k$ & $P=74.40 \mathrm{k}$ & $\mathrm{P}=83.70 \mathrm{k}$ & $P=93.00 k$ \\
\hline G01 & 0 & -17.5049 & -32.8464 & -48.5665 & -55.0281 & -54.6164 & -52.5696 & -49.2607 & -45.4832 & -39.9725 & -35.3992 \\
\hline $\mathrm{G} 02$ & 0 & 18.5888 & 31.8681 & 44.7249 & 57.9786 & 71.5844 & 85.4148 & 99.0562 & 112.5119 & 126.2444 & 139.8398 \\
\hline G03 & 0 & 51.8772 & 89.6922 & 127.8818 & 166.5397 & 205.8945 & 245.6689 & 285.2606 & 324.9502 & 364.5011 & 404.2436 \\
\hline G04 & 0 & 102.3475 & 179.5394 & 255.5361 & 327.0371 & 393.7153 & 458.6832 & 522.6367 & 585.7617 & 648.7552 & 712.1287 \\
\hline G05 & 0 & 98.9472 & 171.9072 & 243.5332 & 310.3006 & 373.0426 & 433.8906 & 493.6327 & 552.2689 & 611.4683 & 670.4427 \\
\hline G06 & 0 & 98.287 & 171.7826 & 244.4528 & 312.3002 & 376.438 & 438.9575 & 500.5549 & 561.2295 & 622.1445 & 682.8804 \\
\hline G07 & 0 & 49.1888 & 83.9934 & 119.4484 & 157.4946 & 196.9339 & 236.6536 & 276.2389 & 316.3374 & 356.3923 & 396.4512 \\
\hline G08 & 0 & 10.0373 & 14.7563 & 20.9563 & 35.4359 & 55.192 & 76.4279 & 98.7307 & 121.0804 & 144.2188 & 166.8961 \\
\hline G09 & 0 & -26.2931 & -48.985 & -69.835 & -77.7233 & -77.3148 & -74.4196 & -69.8609 & -64.3784 & -58.6664 & -52.9071 \\
\hline G10 & 0 & -21.6158 & -42.5761 & -61.1371 & -70.2949 & -71.0181 & -68.1943 & -62.9293 & -57.6203 & -51.1591 & -44.6992 \\
\hline G11 & 0 & 15.8708 & 25.1937 & 35.8117 & 50.6316 & 68.872 & 88.4499 & 108.6764 & 129.1792 & 150.5627 & 170.9722 \\
\hline G12 & 0 & 42.5254 & 73.1808 & 101.6935 & 131.6504 & 161.2854 & 192.3142 & 222.6494 & 253.2676 & 284.6294 & 316.2275 \\
\hline G13 & 0 & 97.3931 & 169.7079 & 240.9199 & 306.2491 & 366.7136 & 424.7722 & 481.3057 & 536.8243 & 592.3026 & 648.3909 \\
\hline G14 & 0 & 101.738 & 177.8579 & 253.6185 & 324.0571 & 390.2387 & 454.7591 & 518.2673 & 580.9022 & 643.637 & 705.8699 \\
\hline G15 & 0 & 98.0574 & 171.056 & 243.6933 & 310.7205 & 374.3652 & 436.113 & 497.4035 & 557.4933 & 617.497 & 677.8335 \\
\hline G16 & 0 & 52.3509 & 88.3769 & 124.1298 & 162.5224 & 201.7067 & 241.2639 & 280.591 & 320.1055 & 359.9472 & 399.5596 \\
\hline G17 & 0 & 18.2846 & 26.4844 & 35.6555 & 52.2915 & 72.7588 & 94.7912 & 117.5176 & 141.2114 & 164.998 & 188.6465 \\
\hline G18 & 0 & 10.3213 & 13.318 & 14.85 & 20.5194 & 28.1234 & 36.8115 & 45.7814 & 55.2192 & 65.0821 & 74.5198 \\
\hline
\end{tabular}




\begin{tabular}{|c|c|c|c|c|c|c|c|c|c|c|c|}
\hline \multirow{2}{*}{ Gage } & \multicolumn{11}{|c|}{ Original Raw Data $(\mathrm{N}=900,000)$} \\
\hline & $=0.00 \mathrm{k}$ & $P=9.30 k$ & $P=18.60 k$ & $P=27.90 k$ & $P=37.20 k$ & $P=46.50 k$ & $P=55.80 k$ & $P=65.10 k$ & $P=74.40 k$ & $P=83.70 k$ & $P=93.00 k$ \\
\hline G01 & 0 & -18.8916 & -37.2284 & -53.0901 & -62.6389 & -63.3489 & -62.2375 & -58.555 & -54.1683 & -49.2216 & -46.0061 \\
\hline $\mathrm{G02}$ & 0 & 18.4515 & 31.6874 & 45.2865 & 57.663 & 71.1291 & 84.5448 & 98.3694 & 112.1461 & 125.6927 & 138.6395 \\
\hline G03 & 0 & 52.1082 & 89.6454 & 128.0205 & 166.355 & 205.5245 & 245.2564 & 284.8003 & 324.7669 & 364.5072 & 403.7837 \\
\hline G04 & 0 & 104.2438 & 182.4988 & 259.8836 & 331.705 & 399.0296 & 463.9466 & 528.2677 & 591.9466 & 654.7967 & 718.3051 \\
\hline G05 & 0 & 99.8472 & 174.0736 & 247.6615 & 314.86 & 377.9398 & 439.0782 & 499.3438 & 558.9658 & 618.1312 & 677.1182 \\
\hline G06 & 0 & 99.5247 & 174.1113 & 248.1049 & 316.2519 & 380.5958 & 442.9949 & 504.2849 & 565.7226 & 626.5163 & 687.0385 \\
\hline G07 & 0 & 49.4333 & 84.2454 & 119.7553 & 156.7945 & 196.0578 & 235.6508 & 275.5237 & 315.6336 & \begin{tabular}{|l|l|}
355.7446 \\
\end{tabular} & 395.1185 \\
\hline G08 & 0 & 9.2987 & 13.2316 & 19.0587 & 32.0577 & 51.1167 & 71.9813 & 93.8174 & 116.5813 & 139.3925 & 162.1129 \\
\hline G09 & 0 & -27.3904 & -51.6013 & -73.0962 & -80.9363 & -81.1722 & -78.5028 & -73.9913 & & -62.1089 & -56.8081 \\
\hline G10 & 0 & -23.3 & -46.265 & -66.8951 & -77.5284 & \begin{tabular}{|l|}
-78.8048 \\
\end{tabular} & -76.6244 & -71.867 & -65.2653 & -58.7559 & -52.9372 \\
\hline G11 & 0 & 14.3525 & 21.8793 & 31.0722 & 44.2787 & 61.3191 & 79.5146 & 99.5566 & 120 & 140.4726 & 160.0565 \\
\hline G12 & 0 & 40.6832 & 69.7152 & 99.4898 & 129.6843 & 159.5534 & 189.5664 & 220.1857 & 250.8978 & 281.9837 & 312.6076 \\
\hline G13 & 0 & 97.3417 & 169.9198 & 241.0227 & 305.9151 & 365.6164 & 423.1428 & \begin{tabular}{|l|l|}
479.1428 \\
\end{tabular} & 534.5456 & 588.7931 & 641.4206 \\
\hline G14 & 0 & 101.9005 & 178.8728 & 255.718 & 326.4516 & 392.8809 & 456.9523 & 520.5223 & 583.1713 & 645.6891 & 707.8901 \\
\hline G15 & 0 & & 171.4646 & 244.8144 & 312.5531 & 375.8398 & 437.3224 & 497.9754 & 558.2643 & \begin{tabular}{|l|l|}
617.9556 \\
\end{tabular} & 677.5151 \\
\hline G16 & 0 & .0283 & 88.1515 & 124.5564 & 162.6759 & 201.818 & 240.6848 & 280.3386 & 320.1325 & 359.8864 & 399.2257 \\
\hline G17 & c & 18. & 26.2669 & .9823 & 50.427 & 70.3471 & 91.7899 & 114.8445 & 138.6851 & 162.2457 & 185.7208 \\
\hline G18 & 0 & 9.575 & 10.6905 & 11.5667 & 15.78 & 22.5863 & 29.7218 & 38.503 & 47.285 & 56.3488 & 64.4679 \\
\hline
\end{tabular}

\begin{tabular}{|c|c|c|c|c|c|c|c|c|c|c|c|c|}
\hline \multirow{2}{*}{ Gage } & \multicolumn{10}{|c|}{ Original Raw Data ( $=1,100,000)$} \\
\cline { 2 - 13 } & $\mathrm{P}=0.00 \mathrm{k}$ & $\mathrm{P}=9.30 \mathrm{k}$ & $\mathrm{P}=18.60 \mathrm{k}$ & $\mathrm{P}=27.90 \mathrm{k}$ & $\mathrm{P}=37.20 \mathrm{k}$ & $\mathrm{P}=46.50 \mathrm{k}=55.80 \mathrm{k}$ & $\mathrm{P}=65.10 \mathrm{k}$ & $\mathrm{P}=74.40 \mathrm{k}$ & $\mathrm{P}=83.70 \mathrm{k}$ & $\mathrm{P}=93.00 \mathrm{k}$ \\
\hline G01 & 0 & -19.0817 & -39.0644 & -56.6631 & -66.4004 & -68.4691 & -66.655 & -64.4684 & -59.6574 & -56.5335 & -51.912 \\
\hline G02 & 0 & 17.9 & 30.8622 & 44.005 & 56.198 & 69.4821 & 83.1279 & 96.9534 & 110.3628 & 123.8662 & 136.9954 \\
\hline G03 & 0 & 51.3635 & 88.2065 & 126.0242 & 164.262 & 203.5692 & 243.0629 & 282.7932 & 322.1076 & 361.4736 & 401.1682 \\
\hline G04 & 0 & 103.9519 & 182.0577 & 260.1293 & 332.9636 & 400.3262 & 465.7462 & 529.5019 & 592.8473 & 655.6432 & 718.3537 \\
\hline G05 & 0 & 99.6139 & 173.6075 & 246.9625 & 315.134 & 378.7229 & 439.907 & 499.4292 & 558.7254 & 617.2408 & 675.855 \\
\hline G06 & 0 & 100.0014 & 174.9684 & 249.3897 & 318.9398 & 383.8488 & 446.5813 & 508.0653 & 569.0458 & 629.5215 & 690.1442 \\
\hline G07 & 0 & 49.1025 & 83.8656 & 119.2326 & 156.1727 & 195.2017 & 234.9269 & 274.2862 & 314.2059 & 353.8028 & 393.4497 \\
\hline G08 & 0 & 8.2346 & 11.3348 & 16.2365 & 28.2188 & 46.6762 & 67.3998 & 89.145 & 111.6313 & 134.4439 & 156.9316 \\
\hline G09 & 0 & -28.9545 & -54.8261 & -78.349 & -89.6487 & -91.1783 & -88.8788 & -84.6908 & -79.6238 & -74.1428 & -68.7992 \\
\hline G10 & 0 & -24.7958 & -49.9024 & -72.6492 & -85.6317 & -88.7986 & -86.386 & -82.3677 & -76.4104 & -70.1319 & -63.7618 \\
\hline G11 & 0 & 13.6166 & 20.268 & 28.0313 & 40.4084 & 57.0821 & 75.7413 & 95.0946 & 115.3256 & 135.4644 & 155.6509 \\
\hline G12 & 0 & 41.2063 & 69.3115 & 98.4427 & 128.4565 & 158.4253 & 188.8614 & 219.0665 & 248.8998 & 279.0156 & 309.645 \\
\hline G13 & 0 & 96.5469 & 167.6821 & 238.8268 & 303.5299 & 363.0417 & 419.6353 & 474.8427 & 528.8485 & 582.1633 & 635.4842 \\
\hline G14 & 0 & 102.3064 & 179.8265 & 257.5441 & 329.8005 & 396.4548 & 461.3551 & 524.7324 & 587.1428 & 649.8402 & 711.988 \\
\hline G15 & 0 & 97.9764 & 172.2374 & 246.2772 & 314.8922 & 378.7775 & 440.8118 & 501.5526 & 561.5568 & 621.1498 & 680.6104 \\
\hline G16 & 0 & 51.8393 & 87.8206 & 124.0834 & 161.7364 & 200.6886 & 239.8272 & 279.2922 & 318.8068 & 358.4643 & 398.0301 \\
\hline G17 & 0 & 17.0916 & 24.1889 & 31.6569 & 45.854 & 65.0343 & 86.75 & 109.6651 & 132.7172 & 156.3705 & 179.9333 \\
\hline G18 & 0 & 9.151 & 10.6471 & 10.7722 & 14.42 & 20.6147 & 28.5519 & 36.7246 & 45.4598 & 54.7609 & 63.5419 \\
\hline
\end{tabular}




\begin{tabular}{|c|c|c|c|c|c|c|c|c|c|c|c|}
\hline \multirow{2}{*}{ Gage } & \multicolumn{11}{|c|}{ Original Raw Data $(N=1,300,000)$} \\
\hline & $P=0.00 k$ & $P=9.30 k$ & $P=18.60 \mathrm{k}$ & $P=27.90 k$ & $P=37.20 k$ & $P=46.50 k$ & $P=55.80 k$ & $P=65.10 k$ & $P=74.40 \mathrm{~K}$ & $P=83.70 k$ & $P=93.00 k$ \\
\hline $\mathrm{G} 01$ & 0 & 3.6177 & -43.6876 & -63.0608 & -74.6683 & -76.7335 & -76.0917 & -74.0444 & -70.1254 & -65.647 & -61.4002 \\
\hline $\mathrm{G} 02$ & & .3511 & 0.2218 & 3.2748 & 55.471 & 68.3885 & 81.8501 & 5.1232 & 108.3005 & 121.8486 & 135.1195 \\
\hline$\overline{\mathrm{G} 03}$ & & 1.2731 & 88.3905 & 126.3012 & 164.3537 & 203.2886 & 243.3402 & 282.8374 & 322.3852 & 362.3522 & 401.8157 \\
\hline G04 & & 105.9505 & 185.3114 & 263.9882 & 338.1717 & 406.4649 & 472.6767 & 537.5033 & 600.9903 & 665.0427 & 727.8019 \\
\hline G05 & & 101.6469 & 177.6752 & 252.2778 & 322.3466 & 387.4162 & 450.0355 & 511.6424 & 572.375 & 632.6506 & 692.8874 \\
\hline G06 & & 101.058 & 176.9927 & 251.8697 & 322.3416 & 388.0346 & 450.8531 & 513.5392 & 574.7459 & 635.8663 & 696.0639 \\
\hline G07 & 0 & 48.6908 & 83.7333 & 118.9633 & 155.9545 & 194.9389 & 234.6685 & 274.6345 & 314.5125 & 354.622 & 394.4125 \\
\hline G08 & 0 & 6.8029 & 9.6247 & 13.7408 & 24.9829 & 42.749 & 63.1541 & \begin{tabular}{|l|}
84.9476 \\
\end{tabular} & 106.6512 & \begin{tabular}{|l|}
130.0219 \\
\end{tabular} & 152.2814 \\
\hline G09 & 0 & 1.5868 & -58.2443 & -82.3695 & -95.2864 & \begin{tabular}{|l|}
-97.5075 \\
\end{tabular} & -95.7622 & -92.1742 & -87 & -81.6718 & 029 \\
\hline G10 & 0 & -27. & -53.0888 & -77.6347 & -91.9569 & $-95 . \varepsilon$ & -94.9237 & |-90.9939 & -85 & -79.6796 & 7238 \\
\hline G11 & 0 & & 18.8772 & 26.7807 & 39.1098 & 55.5014 & 73.74 & 93.5551 & 113.5977 & 134.2417 & 154.7938 \\
\hline G12 & 0 & 40.5482 & 69.8143 & 99.8725 & 130.4875 & 161.2434 & 192.2304 & 223.6454 & \begin{tabular}{|l|l}
254.3607 \\
\end{tabular} & 286.1005 & 317.2879 \\
\hline G13 & 0 & 99.2441 & 173.6782 & 246.6849 & 314.1779 & 376.5263 & 435.6786 & 494.5594 & 550.7533 & 606.396 & 662.1846 \\
\hline G14 & & 103.6229 & 181.76 & 259.6309 & 332.8749 & 400.4229 & 465.9387 & 530.1169 & \begin{tabular}{|l|l|}
593.1431 \\
\end{tabular} & 655.8982 & 718.1973 \\
\hline G15 & 0 & 99.5116 & 174.7505 & 249.3498 & 319.1292 & 384.1318 & 446.6334 & \begin{tabular}{|l|}
508.3061 \\
\end{tabular} & 568.7312 & 628.9313 & 688.7668 \\
\hline G16 & 0 & 51.8966 & 87.7442 & 123.8734 & 161.5332 & 200.9102 & 240.0092 & 279.8064 & 319.3292 & 359.1763 & 398.4254 \\
\hline G17 & 0 & 16.1737 & 22.9496 & 30.3265 & 44.341 & 63.3382 & 84.8262 & \begin{tabular}{|l|}
107.1427 \\
\end{tabular} & 130.5675 & 154.0378 & 177.7867 \\
\hline G18 & 0 & 8.3532 & 9.3763 & 9.1699 & 12.5348 & 19.1066 & 26.9954 & 35.4511 & 44.7022 & 53.9058 & 63.5816 \\
\hline
\end{tabular}

\begin{tabular}{|c|c|c|c|c|c|c|c|c|c|c|c|c|}
\hline \multirow{2}{*}{ Gage } & \multicolumn{9}{|c|}{ Original Raw Data ( $=1,500,000)$} \\
\cline { 2 - 14 } & $\mathrm{P}=0.00 \mathrm{k}$ & $\mathrm{P}=9.30 \mathrm{k}$ & $\mathrm{P}=18.60 \mathrm{k}$ & $\mathrm{P}=27.90 \mathrm{k}$ & $\mathrm{P}=37.20 \mathrm{k}$ & $\mathrm{P}=46.50 \mathrm{k}=55.80 \mathrm{k}$ & $\mathrm{P}=65.10 \mathrm{k}$ & $\mathrm{P}=74.40 \mathrm{k}$ & $\mathrm{P}=83.70 \mathrm{k}$ & $\mathrm{P}=93.00 \mathrm{k}$ \\
\hline G01 & 0 & -23.0565 & -44.0136 & -63.9019 & -76.3007 & -81.1788 & -80.0201 & -77.1307 & -73.3049 & -68.8249 & -63.7828 \\
\hline G02 & 0 & 17.584 & 30.4581 & 43.745 & 55.6231 & 68.4031 & 82.0053 & 95.8324 & 109.2418 & 122.9743 & 136.4769 \\
\hline G03 & 0 & 50.8131 & 87.8395 & 125.5196 & 163.3889 & 202.2799 & 241.6376 & 281.1348 & 321.1013 & 360.5139 & 400.3018 \\
\hline G04 & 0 & 105.2522 & 184.7051 & 263.5203 & 338.0275 & 407.0174 & 472.9959 & 537.7283 & 601.586 & 664.9873 & 728.2574 \\
\hline G05 & 0 & 101.3512 & 177.7375 & 253.0692 & 324.61 & 389.9929 & 453.1121 & 515.3115 & 576.4976 & 636.9957 & 698.0576 \\
\hline G06 & 0 & 100.5859 & 176.7006 & 251.8972 & 322.8747 & 388.6552 & 451.9337 & 514.1972 & 575.3527 & 636.4221 & 697.0802 \\
\hline G07 & 0 & 48.2238 & 83.2652 & 118.1693 & 154.6482 & 193.4906 & 233.0327 & 272.9483 & 312.868 & 352.9309 & 392.902 \\
\hline G08 & 0 & 6.5668 & 9.0654 & 12.3935 & 22.2469 & 39.4992 & 59.3907 & 81.3648 & 103.6654 & 126.3835 & 149.0549 \\
\hline G09 & 0 & -31.2631 & -58.6599 & -84.5378 & -100.037 & -102.949 & -101.989 & -98.213 & -93.5631 & -88.3124 & -82.23 \\
\hline G10 & 0 & -27.4677 & -53.7257 & -79.3251 & -95.8566 & -100.681 & -99.8364 & -95.861 & -90.5494 & -84.7786 & -78.5487 \\
\hline G11 & 0 & 12.4118 & 18.5057 & 25.4865 & 37.0749 & 52.9579 & 71.3835 & 90.915 & 111.3713 & 131.8286 & 152.7033 \\
\hline G12 & 0 & 41.1765 & 70.7046 & 100.6511 & 131.3434 & 161.8934 & 192.777 & 224.03 & 255.4258 & 286.7292 & 318.2677 \\
\hline G13 & 0 & 100.6596 & 176.0056 & 251.2694 & 321.2537 & 384.378 & 446.6282 & 505.1254 & 564.2796 & 621.908 & 678.8 \\
\hline G14 & 0 & 103.1393 & 181.725 & 259.8592 & 334.0168 & 402.016 & 467.1478 & 531.6852 & 594.6994 & 657.2112 & 720.0087 \\
\hline G15 & 0 & 99.3071 & 174.4386 & 249.9532 & 320.2295 & 385.4526 & 448.314 & 509.7427 & 570.6679 & 630.8567 & 691.0063 \\
\hline G16 & 0 & 51.4272 & 87.5948 & 123.4429 & 160.959 & 199.5434 & 238.6858 & 278.4322 & 317.9482 & 357.607 & 397.4526 \\
\hline G17 & 0 & 15.5703 & 21.9291 & 28.6594 & 41.4269 & 59.7744 & 80.4742 & 103.1105 & 126.1161 & 150.0449 & 173.2333 \\
\hline G18 & 0 & 8.4901 & 9.559 & 8.7451 & 11.8269 & 17.877 & 25.2465 & 33.8886 & 42.9052 & 52.4827 & 62.0629 \\
\hline
\end{tabular}




\begin{tabular}{|c|c|c|c|c|c|c|c|c|c|c|c|}
\hline \multirow{2}{*}{ Gage } & \multicolumn{9}{|c|}{ Original Raw Data $(\mathrm{N}=1,900,000)$} \\
\cline { 2 - 13 } & $\mathrm{P}=0.00 \mathrm{k}$ & $\mathrm{P}=9.30 \mathrm{k}$ & $\mathrm{P}=18.60 \mathrm{k}$ & $\mathrm{P}=27.90 \mathrm{k}$ & $\mathrm{P}=37.20 \mathrm{k}$ & $\mathrm{P}=46.50 \mathrm{k}$ & $\mathrm{P}=55.80 \mathrm{k}$ & $\mathrm{P}=65.10 \mathrm{k}$ & $\mathrm{P}=74.40 \mathrm{k}$ & $\mathrm{P}=83.70 \mathrm{k}$ & $\mathrm{P}=93.00 \mathrm{k}$ \\
\hline G01 & 0 & -25.92 & -48.4227 & -69.9057 & -85.8076 & -90.737 & -91.0798 & -88.147 & -85.3561 & -80.6326 & -76.4247 \\
\hline G02 & 0 & 17.1285 & 29.7281 & 42.6477 & 54.8563 & 67.3165 & 80.7351 & 94.4272 & 108.1138 & 121.848 & 135.3039 \\
\hline G03 & 0 & 50.3503 & 86.9129 & 124.2173 & 161.6208 & 200.3705 & 239.5732 & 279.0231 & 318.7068 & 358.6254 & 398.4561 \\
\hline G04 & 0 & 106.284 & 186.7662 & 266.89 & 342.8916 & 412.9105 & 480.2438 & 545.7274 & 609.9179 & 674.0234 & 737.8118 \\
\hline G05 & 0 & 102.9713 & 180.5609 & 257.4212 & 330.2126 & 397.5889 & 462.3308 & 525.4573 & 586.9217 & 648.9969 & 710.5233 \\
\hline G06 & 0 & 102.2316 & 178.8841 & 255.5021 & 327.577 & 394.8287 & 459.3467 & 522.1062 & 583.8507 & 645.4171 & 706.1997 \\
\hline G07 & 0 & 48.3172 & 82.847 & 117.9811 & 154.1823 & 193.0254 & 232.5183 & 272.7127 & 312.6328 & 352.8786 & 392.6648 \\
\hline G08 & 0 & 4.9072 & 6.0635 & 8.4674 & 16.562 & 32.7535 & 52.3695 & 73.0971 & 95.2622 & 117.8434 & 140.3341 \\
\hline G09 & 0 & -34.1692 & -63.7309 & -91.1322 & -108.8 & -113.88 & -114.213 & -111.686 & -107.128 & -102.017 & -96.95 \\
\hline G10 & 0 & -29.7315 & -58.2039 & -85.8791 & -104.436 & -112.905 & -113.811 & -111.54 & -106.733 & -101.101 & -95.5596 \\
\hline G11 & 0 & 11.5316 & 16.3335 & 22.2947 & 32.4066 & 47.0879 & 64.5897 & 83.6576 & 103.3734 & 124.0133 & 144.6079 \\
\hline G12 & 0 & 40.8775 & 70.014 & 99.531 & 129.8789 & 160.5648 & 190.971 & 222.6299 & 253.7375 & 285.3109 & 316.9334 \\
\hline G13 & 0 & 101.1344 & 176.9047 & 252.1771 & 322.6796 & 387.7136 & 448.8099 & 507.8705 & 565.4521 & 623.2262 & 680.3565 \\
\hline G14 & 0 & 104.4706 & 183.6841 & 263.328 & 338.3912 & 408.0366 & 474.443 & 538.7694 & 603.0579 & 666.3794 & 729.0591 \\
\hline G15 & 0 & 100.3313 & 176.812 & 252.6544 & 324.1878 & 390.9462 & 454.9719 & 516.8215 & 577.8423 & 638.8704 & 699.2554 \\
\hline G16 & 0 & 51.2416 & 86.9451 & 123.2093 & 160.771 & 199.4016 & 238.4952 & 278.0557 & 317.803 & 357.6434 & 397.5365 \\
\hline G17 & 0 & 14.1893 & 19.4875 & 25.6188 & 36.9129 & 54.3866 & 74.5826 & 96.577 & 119.447 & 143.1487 & 166.4782 \\
\hline G18 & 0 & 7.7846 & 8.1005 & 7.3334 & 9.6646 & 15.3847 & 22.4701 & 30.7775 & 39.6517 & 49.323 & 58.9929 \\
\hline
\end{tabular}

\begin{tabular}{|c|c|c|c|c|c|c|c|c|c|c|c|c|}
\hline \multirow{2}{*}{ Gage } & \multicolumn{10}{|c|}{ Original Raw Data ( $=2,100,000)$} \\
\cline { 2 - 13 } & $\mathrm{P}=0.00 \mathrm{k}$ & $\mathrm{P}=9.30 \mathrm{k}$ & $\mathrm{P}=18.60 \mathrm{k}$ & $\mathrm{P}=27.90 \mathrm{k}$ & $\mathrm{P}=37.20 \mathrm{k}$ & $\mathrm{P}=46.50 \mathrm{k}$ & $\mathrm{P}=55.80 \mathrm{k}$ & $\mathrm{P}=65.10 \mathrm{k}$ & $\mathrm{P}=74.40 \mathrm{k}$ & $\mathrm{P}=83.70 \mathrm{k}$ & $\mathrm{P}=93.00 \mathrm{k}$ \\
\hline G01 & 0 & -25.2176 & -48.8042 & -70.1022 & -86.1534 & -93.5269 & -94.9944 & -92.5189 & -89.4347 & -85.4156 & -80.3605 \\
\hline G02 & 0 & 16.4851 & 28.6725 & 41.7826 & 53.5786 & 65.8601 & 79.7435 & 93.3914 & 106.9415 & 120.864 & 134.3691 \\
\hline G03 & 0 & 50.0245 & 86.3564 & 123.3396 & 161.2049 & 199.5893 & 238.9447 & 278.4873 & 317.7559 & 358.0467 & 397.5063 \\
\hline G04 & 0 & 106.0482 & 186.0639 & 266.6029 & 343.4387 & 414.6634 & 481.3447 & 547.1049 & 610.8284 & 674.514 & 738.2539 \\
\hline G05 & 0 & 102.5889 & 180.448 & 257.6706 & 331.5666 & 399.8631 & 464.2734 & 527.7179 & 589.2689 & 651.0124 & 712.3926 \\
\hline G06 & 0 & 101.5332 & 178.3235 & 255.126 & 328.6404 & 396.3094 & 460.594 & 523.3985 & 584.91 & 646.1495 & 707.2102 \\
\hline G07 & 0 & 47.9454 & 82.5682 & 117.4235 & 153.4859 & 191.9573 & 231.451 & 271.457 & 311.1431 & 351.4345 & 391.4509 \\
\hline G08 & 0 & 4.5831 & 5.6475 & 7.8669 & 14.3878 & 29.2827 & 48.8073 & 69.7177 & 91.9743 & 114.5558 & 136.9519 \\
\hline G09 & 0 & -34.2587 & -63.8646 & -92.0931 & -112.481 & -119.497 & -119.826 & -117.252 & -112.926 & -107.997 & -102.747 \\
\hline G10 & 0 & -29.8216 & -57.8787 & -86.7942 & -108.254 & -117.179 & -118.684 & -115.859 & -111.377 & -105.788 & -100.111 \\
\hline G11 & 0 & 11.3939 & 16.5641 & 21.603 & 30.7454 & 44.9195 & 62.5594 & 81.721 & 101.806 & 122.2142 & 142.9474 \\
\hline G12 & 0 & 40.8069 & 69.9348 & 99.8379 & 130.3569 & 160.2077 & 191.4 & 222.7332 & 254.1114 & 286.0075 & 317.3381 \\
\hline G13 & 0 & 101.6372 & 177.7282 & 253.8771 & 326.1385 & 391.076 & 451.9831 & 512.0153 & 570.5221 & 628.4321 & 685.745 \\
\hline G14 & 0 & 103.5082 & 182.499 & 262.4765 & 338.6149 & 408.4075 & 474.8678 & 539.5729 & 602.9403 & 665.6188 & 728.5377 \\
\hline G15 & 0 & 100.44 & 176.8401 & 253.4837 & 326.7473 & 393.9349 & 457.9245 & 520.342 & 581.2333 & 641.8998 & 702.5733 \\
\hline G16 & 0 & 51.3821 & 86.9451 & 123.3036 & 160.3547 & 199.0807 & 237.8966 & 277.1336 & 316.9274 & 356.678 & 396.4768 \\
\hline G17 & 0 & 14.7442 & 20.5484 & 25.9885 & 35.7609 & 52.4513 & 72.5088 & 94.5928 & 117.5544 & 140.8843 & 164.1704 \\
\hline G18 & 0 & 7.5938 & 8.4763 & 7.5705 & 9.1026 & 13.9294 & 20.7318 & 29.1344 & 37.7234 & 47.2524 & 57.1116 \\
\hline
\end{tabular}




\begin{tabular}{|c|c|c|c|c|c|c|c|c|c|c|c|}
\hline \multirow{2}{*}{ Gage } & \multicolumn{9}{|c|}{ Original Raw Data $(\mathrm{N}=2,300,000)$} \\
\cline { 2 - 14 } & $\mathrm{P}=0.00 \mathrm{k}$ & $\mathrm{P}=9.30 \mathrm{k}$ & $\mathrm{P}=18.60 \mathrm{k}$ & $\mathrm{P}=27.90 \mathrm{k}$ & $\mathrm{P}=37.20 \mathrm{k}$ & $\mathrm{P}=46.50 \mathrm{k}$ & $\mathrm{P}=55.80 \mathrm{k}$ & $\mathrm{P}=65.10 \mathrm{k}$ & $\mathrm{P}=74.40 \mathrm{k}$ & $\mathrm{P}=83.70 \mathrm{k}$ & $\mathrm{P}=93.00 \mathrm{k}$ \\
\hline G01 & 0 & -25.6366 & -48.0008 & -69.5317 & -87.0303 & -94.0283 & -94.7895 & -93.8667 & -90.3606 & -87.5121 & -82.8333 \\
\hline G02 & 0 & 17.8737 & 30.8023 & 45.3491 & 55.296 & 67.4373 & 81.6944 & 94.2334 & 107.5532 & 120.6883 & 134.194 \\
\hline G03 & 0 & 50.3653 & 86.7193 & 123.647 & 161.3438 & 199.7248 & 238.8469 & 278.2515 & 317.7519 & 357.1628 & 397.088 \\
\hline G04 & 0 & 105.9957 & 186.146 & 267.0055 & 344.3012 & 415.2436 & 482.4784 & 547.3055 & 611.3512 & 674.568 & 738.3972 \\
\hline G05 & 0 & 102.9206 & 180.3214 & 257.8273 & 332.0998 & 400.0302 & 464.0273 & 526.3167 & 587.4077 & 648.4135 & 709.3804 \\
\hline G06 & 0 & 101.7735 & 179.2203 & 256.4469 & 330.5712 & 398.2457 & 463.0931 & 525.7176 & 587.0946 & 648.4319 & 709.1256 \\
\hline G07 & 0 & 48.1742 & 82.7032 & 117.4635 & 153.7075 & 191.8041 & 231.0177 & 270.8807 & 310.9341 & 350.6686 & 390.7265 \\
\hline G08 & 0 & 4.9064 & 6.017 & 7.6801 & 14.2032 & 28.7711 & 47.7387 & 68.6035 & 90.5802 & 112.9755 & 135.4172 \\
\hline G09 & 0 & -34.223 & -63.829 & -92.796 & -113.273 & -120.701 & -121.622 & -118.718 & -114.156 & -108.994 & -104.108 \\
\hline G10 & 0 & -29.7379 & -58.5415 & -88.2486 & -110.632 & -121.264 & -123.182 & -120.679 & -116.06 & -110.379 & -104.514 \\
\hline G11 & 0 & 11.1221 & 16.2462 & 20.8732 & 29.3702 & 42.3932 & 59.6249 & 78.24 & 98.2869 & 118.3376 & 138.7144 \\
\hline G12 & 0 & 38.2891 & 66.5681 & 93.9843 & 122.5333 & 151.8191 & 181.0259 & 210.3165 & 239.3277 & 253.3365 & 279.9908 \\
\hline G13 & 0 & 99.6847 & 173.3935 & 246.1385 & 314.5753 & 376.6597 & 433.6431 & 487.9851 & 542.5651 & 596.2685 & 649.2344 \\
\hline G14 & 0 & 92.0964 & 167.9752 & 246.9739 & 320.9275 & 383.0122 & 443.7587 & 508.5043 & 582.961 & 644.5675 & 707.0173 \\
\hline G15 & 0 & 100.458 & 176.7788 & 253.9007 & 327.038 & 393.7262 & 456.9371 & 518.8076 & 579.3376 & 639.6426 & 699.7216 \\
\hline G16 & 0 & 51.4232 & 87.4469 & 123.1929 & 160.3333 & 198.6652 & 237.1167 & 277.1034 & 316.4356 & 356.101 & 395.6728 \\
\hline G17 & 0 & 14.3283 & 19.8103 & 24.7892 & 34.3775 & 50.7446 & 70.2904 & 92.419 & 115.6094 & 138.6622 & 162.0365 \\
\hline G18 & 0 & 7.2715 & 8.0618 & 7.817 & 9.211 & 13.5203 & 20.4701 & 28.642 & 37.426 & 46.3498 & 55.1294 \\
\hline
\end{tabular}

\begin{tabular}{|c|c|c|c|c|c|c|c|c|c|c|c|}
\hline \multirow{2}{*}{ Gage } & \multicolumn{11}{|c|}{ Original Raw Data $(\mathrm{N}=2,500,000)$} \\
\hline & $P=0.00 k$ & $P=9.30 k$ & $P=18.60$ & $P=27.90$ & $P=37.20 k$ & $P=46.50 k$ & $P=55.80 k$ & $P=65.10 k$ & $P=74.40 k$ & $P=83.70 k$ & $P=93.00 k$ \\
\hline G01 & 0 & -27.5669 & -51.4141 & -74.9191 & -92.7058 & -101.34 & -102.802 & -101.318 & -97.8927 & -94.3862 & -90.9726 \\
\hline $\mathrm{G} 02$ & 0 & 16.6721 & 28.5375 & 42.0187 & 53.3102 & 64.9904 & 78.553 & 91.4607 & 104.7365 & 118.7502 & 131.3315 \\
\hline G03 & 0 & 49.8795 & 86.0708 & 123.4203 & 160.6834 & 198.891 & 239.7316 & 277.4182 & 316.6842 & 356.4179 & 395.9704 \\
\hline G04 & 0 & 106.0873 & 186.9333 & 268.4422 & 345.9232 & 417.2827 & 488.1879 & 549.8084 & 613.6673 & 677.2555 & 740.7124 \\
\hline G05 & 0 & 103.6709 & 181.5426 & 260.1217 & 334.9108 & 403.6358 & 472.138 & 532.1608 & 593.7214 & 655.151 & 716.7732 \\
\hline G06 & 0 & 102.6685 & 179.939 & 257.361 & 331.4479 & 399.6884 & 467.1944 & 527.0364 & 588.2809 & 648.9289 & 709.9559 \\
\hline G07 & 0 & 48.0878 & 82.3893 & 117.3846 & 153.0787 & 191.1352 & 232.4853 & 270.3634 & 310.192 & 349.9747 & 389.9029 \\
\hline G08 & 0 & 4.6289 & 5.2316 & 6.6173 & 12.5838 & 27.1 & 46.4 & 292 & & 0892 & .4883 \\
\hline G09 & 0 & -35.5988 & -65.4369 & & & & & & & & \\
\hline$G$ & & & & & & & & & & 219 & \\
\hline G1 & 0 & & & & & & & & 975 & 2059 & 024 \\
\hline G12 & 0 & .6252 & 696 & 96.714 & & 155.7675 & 9075 & 215.5289 & 246.0749 & 6116 & 954 \\
\hline G13 & 0 & 101.2092 & 176.6768 & 252.7589 & 324.5348 & 388.8451 & 452.5131 & 507.2246 & 563.8005 & .9182 & 5776 \\
\hline G14 & 0 & 104.6272 & 184.3643 & 265.0419 & 342.1597 & 412.5131 & 482.4585 & 543.8723 & 606.7792 & 669.3223 & 985 \\
\hline G15 & 0 & 101.0129 & 177.5641 & 255.0558 & 328.6099 & 395.8543 & 462.9217 & 521.5377 & 581.9736 & 642.2307 & 02.4017 \\
\hline G16 & 0 & .524 & 87.1869 & 123.0343 & 160.0459 & 198.0321 & 239.077 & 276.418 & 315.5227 & 355.6005 & 394.8494 \\
\hline G17 & $\mathrm{c}$ & 13.8 & 18.5188 & & & & 0928 & 909 & 2427 & 136.0321 & .2248 \\
\hline G18 & 0 & 6.2918 & 6.3894 & 5.5438 & 6.1555 & 9.9708 & 16.7127 & 24.7202 & 33.3904 & 42.625 & 51.2471 \\
\hline
\end{tabular}




\begin{tabular}{|c|c|c|c|c|c|c|c|c|c|c|c|}
\hline \multirow{2}{*}{ Gage } & \multicolumn{11}{|c|}{ Original Raw Data $(N=2,700,000)$} \\
\hline & $P=0.00 k$ & $P=9.30 k$ & $P=18.60 \mathrm{k}$ & $P=27.90 k$ & $P=37.20 k$ & $P=46.50 k$ & $P=55.80 k$ & $P=65.10 k$ & $P=74.40 k$ & $P=83.70 k$ & $P=93.00 k$ \\
\hline $\mathrm{G} 01$ & 0 & 7.8982 & -50.9693 & -73.7732 & -92.9617 & -100.189 & -102.359 & -101.949 & -97.594 & -94.1816 & $\mid-90.1116$ \\
\hline $\mathrm{G02}$ & 0 & 16.1734 & 27.8141 & 40.4694 & 51.8625 & 63.5511 & 76.6125 & 89.8984 & 103.5486 & 116.9674 & 130.3374 \\
\hline G03 & & 49.2869 & 84.8789 & 122.096 & 158.9005 & 197.0517 & 235.8526 & 275.4452 & 315.1318 & 354.7302 & 394.0981 \\
\hline G04 & & 106.9045 & 186.7491 & 267.9543 & 346.1519 & 418.2274 & 486.2229 & 551.6709 & 615.8724 & 679.7564 & 743.0904 \\
\hline G05 & & 103.7292 & 181.8533 & 260.9162 & 336.2372 & 405.8669 & 472.0288 & 535.2774 & 597.8854 & 659.6198 & 720.8046 \\
\hline G06 & & 103.0561 & 179.9789 & 257.7034 & 332.6054 & 401.8952 & 466.7318 & 530.1831 & 592.0142 & 653.1092 & 713.9332 \\
\hline G07 & 0 & 47.6608 & 81.7696 & 117.0349 & 152.4415 & 190.7199 & 230.2076 & 270.0678 & 309.9786 & 350.2628 & 390.041 \\
\hline G08 & 0 & 3.3799 & 3.7525 & 5.0918 & 9.8545 & 23.0854 & 41.4521 & \begin{tabular}{|l|}
62.3205 \\
\end{tabular} & \begin{tabular}{|l|}
84.0671 \\
\end{tabular} & 106.5115 & 128.9083 \\
\hline G09 & 0 & -37.5436 & -68.9085 & -99.2658 & -122.794 & -132.717 & -135.308 & -133.47 & -129.603 & -124.998 & -119.466 \\
\hline G10 & 0 & -32.037 & -61.8 & -92.9356 & -117.759 & -130 & 4.134 & 184 & & 2.85 & 125 \\
\hline G11 & 0 & 10.4715 & 14.9009 & 19.1986 & 26.4487 & 39.4701 & 55.9054 & 74.7438 & 94.6408 & 114.8616 & 135.5008 \\
\hline G12 & 0 & 40.5949 & 69.1046 & 98.2711 & 127.5172 & 157.8568 & 188.4182 & 219.2152 & 250.5894 & 282.1184 & 313.2992 \\
\hline G13 & 0 & 100.9029 & 178.1599 & 253.6647 & 326.7673 & 393.1489 & 454.943 & 514.3298 & 572.3773 & 630.6634 & 685.9835 \\
\hline G14 & 0 & 104.9328 & 184.5522 & 265.5756 & 343.5959 & 415.3141 & 483.0035 & \begin{tabular}{|l|}
547.9624 \\
\end{tabular} & 611.6758 & 674.9326 & 736.9896 \\
\hline G15 & 0 & 101.2528 & 177.6709 & 255.5407 & 330.1699 & 398.8142 & 463.6559 & 526.2745 & 587.3674 & 648.1409 & 708.1319 \\
\hline G16 & $\overline{0}$ & 50.6808 & 86.4749 & 122.4097 & 159.0878 & 197.5769 & 236.6683 & 276.2711 & 315.5976 & 355.3895 & 394.9084 \\
\hline G17 & 0 & 12.8046 & 17.1795 & 21.6944 & 30.0834 & 45.0646 & 64.3315 & 85.676 & 108.217 & 131.681 & 154.9174 \\
\hline G18 & 0 & 6.6101 & 6.9737 & 6.3041 & 7.2255 & 11.4411 & 18.0104 & 25.8484 & 34.6281 & 44.1604 & 53.7398 \\
\hline
\end{tabular}

\begin{tabular}{|c|c|c|c|c|c|c|c|c|c|c|c|c|}
\hline \multirow{2}{*}{ Gage } & \multicolumn{10}{|c|}{ Original Raw Data ( $=2,900,000)$} \\
\cline { 2 - 13 } & $\mathrm{P}=0.00 \mathrm{k}$ & $\mathrm{P}=9.30 \mathrm{k}$ & $\mathrm{P}=18.60 \mathrm{k}$ & $\mathrm{P}=27.90 \mathrm{k}$ & $\mathrm{P}=37.20 \mathrm{k}$ & $\mathrm{P}=46.50 \mathrm{k}$ & $\mathrm{P}=55.80 \mathrm{k}$ & $\mathrm{P}=65.10 \mathrm{k}$ & $\mathrm{P}=74.40 \mathrm{k}$ & $\mathrm{P}=83.70 \mathrm{k}$ & $\mathrm{P}=93.00 \mathrm{k}$ \\
\hline G01 & 0 & -26.726 & -50.4601 & -74.7172 & -94.0959 & -102.969 & -105.559 & -104.679 & -102.11 & -100.013 & -96.6 \\
\hline G02 & 0 & 16.5429 & 28.3215 & 41.3041 & 53.2069 & 67.3955 & 80.1338 & 93.5582 & 106.9778 & 122.5277 & 135.7141 \\
\hline G03 & 0 & 49.7058 & 86.3365 & 122.8199 & 160.0908 & 198.1552 & 237.007 & 276.327 & 316.1563 & 355.4794 & 395.3172 \\
\hline G04 & 0 & 106.7537 & 187.7982 & 269.5987 & 348.1135 & 420.4605 & 488.1241 & 553.4724 & 617.8529 & 681.219 & 744.8259 \\
\hline G05 & 0 & 103.6152 & 182.36 & 260.9784 & 336.5026 & 405.8705 & 471.4916 & 534.3379 & 596.0327 & 657.4099 & 718.2847 \\
\hline G06 & 0 & 103.1362 & 181.1988 & 259.0418 & 333.7818 & 403.4198 & 468.5563 & 531.4698 & 592.9498 & 653.8788 & 714.9543 \\
\hline G07 & 0 & 47.5757 & 82.2468 & 116.8709 & 152.4237 & 190.3416 & 229.2804 & 268.8244 & 308.6494 & 348.8498 & 388.5432 \\
\hline G08 & 0 & 3.3785 & 3.8887 & 3.9338 & 8.5581 & 21.5094 & 39.458 & 59.9065 & 81.79 & 104.0459 & 126.394 \\
\hline G09 & 0 & -36.5756 & -67.6655 & -98.6666 & -122.38 & -133.179 & -135.584 & -133.93 & -129.737 & -124.947 & -119.972 \\
\hline G10 & 0 & -31.7152 & -61.5767 & -93.2141 & -118.728 & -131.753 & -135.56 & -133.797 & -129.496 & -124.231 & -118.737 \\
\hline G11 & 0 & 10.2402 & 14.2535 & 17.6768 & 24.7432 & 36.8443 & 52.5431 & 70.9696 & 90.4575 & 110.4548 & 130.7273 \\
\hline G12 & 0 & 39.7518 & 68.2126 & 96.4389 & 125.5015 & 154.8047 & 184.4773 & 214.5218 & 245.0385 & 275.4131 & 305.8836 \\
\hline G13 & 0 & 98.8759 & 173.6843 & 248.1792 & 318.3207 & 382.2041 & 441.6381 & 498.1998 & 553.5599 & 608.0903 & 662.0689 \\
\hline G14 & 0 & 104.7397 & 185.0022 & 267.1342 & 345.1486 & 417.2338 & 484.8723 & 549.6869 & 613.2104 & 676.1378 & 739.2127 \\
\hline G15 & 0 & 100.9746 & 177.7176 & 255.6803 & 330.2167 & 398.4892 & 463.0983 & 525.0668 & 586.4843 & 646.3743 & 706.5978 \\
\hline G16 & 0 & 51.5178 & 87.3119 & 123.1581 & 159.933 & 197.9148 & 236.9162 & 276.2431 & 315.7579 & 355.5992 & 395.2587 \\
\hline G17 & 0 & 13.2208 & 18.1953 & 22.0673 & 30.3654 & 44.6112 & 63.3298 & 84.8153 & 107.3593 & 130.5503 & 154.0644 \\
\hline G18 & 0 & 6.2847 & 7.1682 & 5.8875 & 6.2473 & 9.5232 & 15.7186 & 23.1373 & 31.8272 & 41.0816 & 50.3827 \\
\hline
\end{tabular}

